\author{
UNIVERSIDADE DE SÃO PAULO \\ INSTITUTO DE ESTUDOS BRASILEIROS \\ PROGRAMA DE PÓS-GRADUAÇÃO \\ CULTURAS E IDENTIDADES BRASILEIRAS
}

MAGDA HOLAN YU CHANG

O padrão de inserção internacional da economia brasileira entre 1945 e 1980

Uma análise da interação entre política econômica e política externa 


\author{
UNIVERSIDADE DE SÃO PAULO \\ INSTITUTO DE ESTUDOS BRASILEIROS \\ PROGRAMA DE PÓS-GRADUAÇÃO \\ CULTURAS E IDENTIDADES BRASILEIRAS
}

\title{
O padrão de inserção internacional da economia brasileira entre 1945 e 1980 \\ Uma análise da interação entre política econômica e política externa
}

\author{
Magda Holan Yu Chang \\ Dissertação apresentada ao Programa de Pós- \\ Graduação em Culturas e Identidades \\ Brasileiras do Instituto de Estudos Brasileiros \\ da Universidade de São Paulo para obtenção \\ do título de Mestre em Filosofia
}

Área de Concentração: Estudos Brasileiros

Orientador: Prof. Dr. Alexandre de Freitas

Barbosa

\section{VERSÃO CORRIGIDA}

$A$ versão original encontra-se disponivel na

Biblioteca do Instituto de Estudos Brasileiros da USP.

São Paulo 
Autorizo a reprodução e divulgação total ou parcial deste trabalho, por qualquer meio convencional ou eletrônico, para fins de estudo e pesquisa, desde que citada a fonte.

\section{DADOS DE CATALOGAÇÃO NA PUBLICAÇÃO (CIP)}

Serviço de Biblioteca e Documentação do

Instituto de Estudos Brasileiros da Universidade de São Paulo

(C) reprodução total

Chang, Magda Holan Yu

O padrão de inserção internacional da economia brasileira entre 1945 e 1980: uma análise da interação entre política econômica e política externa / Magda Holan Yu Chang. -- São Paulo, 2014.

Orientador : Prof. Dr. Alexandre de Freitas Barbosa.

Dissertação (Mestrado) - Universidade de São Paulo. Instituto de Estudos Brasileiros. Programa de Pós-Graduação. Área de concentração: Estudos Brasileiros. Linha de pesquisa: Brasil: a realidade da criação, a criação da realidade.

Versão do título para o inglês: The international insertion pattern of the brazilian economy between 1945 and 1980: an analysis of the interaction between economic policy and foreign policy.

Descritores: 1. Política econômica - Brasil - 1945-1980 2. Política externa - Brasil - 1945-1980 3. Política de desenvolvimento - Brasil 1945-1980 4. Relações internacionais - Brasil - 1945-1980

I. Universidade de São Paulo. Instituto de Estudos Brasileiros.

Programa de Pós-Graduação II. Título. 


\section{CHANG, Magda Holan Yu}

O padrão de inserção internacional da economia brasileira entre 1945 e 1980: Uma análise da interação entre política econômica e política externa

Dissertação apresentada ao Programa de

Pós-Graduação em Culturas e

Identidades Brasileiras do Instituto de

Estudos Brasileiros da Universidade de

São Paulo, para obtenção do título de

Mestre em Filosofia.

Área de Concentração Estudos

Brasileiros

Aprovado em:

Banca Examinadora

Prof. Dr.

Instituição:

Assinatura:

Prof. Dr.

Instituição: Assinatura:

Prof. Dr.

Instituição:

Assinatura: 
Para meus queridos pais e irmãos.

E para Ricky, meu amor. 


\section{Agradecimentos}

Meu primeiro agradecimento é para minha família. Aos meus pais, por todo o amor e força que sempre me deram. Ao meu pai, quem me ensinou não apenas a importância dos estudos, mas principalmente, a gostar de estudar. À minha mãe, quem sempre cuidou de mim, até mesmo abastecendo minha geladeira de congelados nos períodos mais críticos de minha pesquisa. Aos meus irmãos, pela parceria de uma vida inteira, pela amizade inestimável. À minha tia Iá, por ser a segunda mãe de todos nós. Às minhas pequenas, Laika, Leona e Lótus. Vocês enchem minha vida de amor e alegria.

Ao professor Alexandre, pela contagiante paixão pelo ensino e pela pesquisa, por alargar meus horizontes de pensamento e mostrar-me todo um universo de novas perspectivas com sua orientação generosa e cuidadosa. Com o senhor entendi o verdadeiro significado da palavra Mestre.

À professora Flávia, a primeira pessoa que semeou a sementinha do mestrado em minha cabeça, por sempre estar presente com palavras de incentivo, carinho e compreensão.

Aos professores Marcos e Telê, pelos exemplos de seriedade na vida acadêmica e de profunda sensibilidade humana, além de todo o apoio que me deram.

À professora Monica, pela força que me deu e pela sua presença alegre e divertida.

Aos professores Ana Paula, Fernando, Jaime, Stelio e Vanderli, pelas generosas manifestações de apoio e estímulo.

Às professoras Ana Lanna e Maria Angela, pelo incentivo que sempre me deram na difícil tarefa de conciliar a pesquisa de mestrado com a rotina de trabalho na universidade. 
À minha equipe no IEB: Lúcia, Cristina, Walquíria e Daniele. Não tenho palavras para descrevê-las. Vocês são simplesmente maravilhosas.

À minha "equipe-aluna" no IEB: Amanda, Gabriela, Matheus, Nadiesda, Rafael e Renan. Muito obrigada por tornarem nosso dia-a-dia mais leve e interessante.

À Fernanda, pelos conselhos e por compartilhar as angústias e anseios da pesquisa acadêmica.

À Inês, pela paciência de mãe, me ouvindo e aconselhando desde o primeiro momento em que coloquei os pés no IEB.

À Bete e Stefanie, pela amizade sincera que me é muito querida, e por me mostrarem que a humanidade ainda tem jeito.

Ao Henrique, companheiro de batalha, pelas interessantes discussões acadêmicas e apoio amigo.

À Cecília, Cíntia, Joana, Letícia e Neide, amigas inesquecíveis, que embora fisicamente distantes, sempre estiveram próximas.

A todos os funcionários e estagiários do IEB e da USP, que tornaram e tornam possível, com seu esforço de todo dia, a realização deste e de inúmeros outros mestrados e pesquisas.

Por fim, mas não menos importante, ao Ricky, simplesmente por existir, ser quem é, e sempre estar ao meu lado, com coração, braços e ouvidos abertos. 
I thank whatever gods may be For my unconquerable soul.

$$
\text { [...] }
$$

I am the master of my fate:

I am the captain of my soul.

Nelson Mandela 


\section{RESUMO}

CHANG, Magda Holan Yu. O padrão de inserção internacional da economia brasileira entre 1945 e 1980: Uma análise da interação entre política econômica e política externa. 2014. 306 fls. Dissertação (Mestrado) - Instituto de Estudos Brasileiros, Universidade de São Paulo. São Paulo, 2014.

Este trabalho visa a avaliar o papel da ação estatal, no âmbito da política econômica e da política externa, para as mudanças no padrão de inserção internacional da economia brasileira entre 1945 e 1980, período em que o país consolidou-se como semiperiferia industrializada da "economia-mundo capitalista". Para além do arcabouço teórico de "sistemas mundo" utilizado para abarcar os determinantes sistêmicos que influíram sobre a inserção internacional da economia brasileira e sobre ambas as políticas econômica e externa, a dissertação recorre ainda às formulações das áreas da história econômica, economia política e relações internacionais para subsidiar a análise. Por fim, o trabalho realiza uma análise comparativa entre os instrumentos da política econômica e da política externa que atuaram sobre esse padrão de inserção, avaliando as formas de interação que se estabeleceram entre esses instrumentos e as suas implicações para a alteração da inserção internacional da economia brasileira.

Palavras-chave: economia brasileira, inserção internacional, política econômica, política externa. 


\begin{abstract}
CHANG, Magda Holan Yu. The international insertion pattern of the Brazilian economy between 1945 and 1980: An analysis of the interaction between economic policy and foreign policy. 2014. 306 fls. Dissertação (Mestrado) - Instituto de Estudos Brasileiros, Universidade de São Paulo. São Paulo, 2014.

This study aims to analyze the government's role, through its economic policy and foreign relations policy, for the change in the Brazilian economy's international insertion pattern between 1945 and 1980, period when the country consolidated itself as part of the industrialized semi-periphery in the "capitalist world-economy". In addition to the theoretical framework of "world systems" used to explain the systemic elements that influenced the Brazilian economy's international insertion and the economic policy and the foreign relations policy, the dissertation also uses ideas from the areas of economic history, political economy and international relations to support the analysis. Finally, the study makes a comparative analysis between the instruments of economic policy and foreign policy that influenced on this pattern of insertion, evaluating the interaction forms established between them and their implications for the change in the Brazilian economy's international insertion pattern.
\end{abstract}

Keywords: Brazilian economy, international insertion, economic policy, foreign policy. 


\section{LISTA DE GRÁFICOS}

Gráfico 1 - Taxa anual de crescimento real do PIB brasileiro, \% a.a., 1945-1980 _....267

Gráfico 2 - Composição do PIB brasileiro, \% PIB, 1945-1980 _.............................. 268

Gráfico 3 - Formação bruta de capital fixo total e do governo federal, \% PIB, 1945-

1980

Gráfico 4 - Composição do PIB por atividade econômica, 1947-1980 .................... 271

Gráfico 5 - Composição do PIB por ramos de serviços, 1947-1980 ........................ 272

Gráfico 6 - Composição do PIB por ramos da indústria, 1947-1980 ........................ 273

Gráfico 7 - Composição da produção da indústria de transformação, \% do total, 1939-

1980 273

Gráfico 8 - Índices de produção industrial por categoria de uso, 1975-1980 ............ 274

Gráfico 9 - Balanço de pagamentos e balança comercial, US\$ milhões, 1945-1980.. 275

Gráfico 10 - Balança comercial e Termos de troca, US\$ milhões e Índice (2006=100),

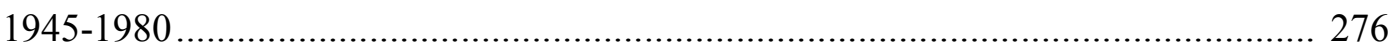

Gráfico 11 - Exportações e importações, \% do PIB, 1947-1980 …......................... 277

Gráfico 12 - Coeficiente de abertura econômica, \% do PIB, 1947-1980 .................. 277

Gráfico 13 - Capacidade de importação, índice (média 2006=100), 1945-1980 _....... 278

Gráfico 14 - Composição das exportações, \% total de exportações, 1945-1980 ........ 279

Gráfico 15 - Composição das importações, \% total de importações, 1945-1980 ....... 279

Gráfico 16 - Exportações por destino, \% total de exportações, 1945-1980............... 281

Gráfico 17 - Importações por origem, \% total de importações, 1945-1980 ............... 281

Gráfico 18 - Saldo comercial por parceiro, US\$, 1945-1980 …........................... 283

Gráfico 19 - Conta capital e financeira, US\$ milhões, 1947-1980 ......................... 284

Gráfico 20 - IED, empréstimos diretos de bancos internacionais, e empréstimos e financiamentos do FMI e organismos e agências multilaterais, US\$ milhões, 1945-1980

Gráfico 21 - Dívida externa brasileira, US\$ milhões, 1946-1980 ........................... 286

Gráfico 22 - Juros, amortizações, e lucros e dividendos, US\$ milhões, 1947-1980 ... 287 


\section{LISTA DE TABELAS}

Tabela 1 - Sentido geral dos eixos da PIIEB, formas de interação entre ambos e implicações para a inserção internacional da economia brasileira ........................... 259

Tabela 2 - Instituições criadas pelo Estado brasileiro entre 1945 e 1980 .................. 270 


\section{LISTA DE SIGLAS}

AID Act of International Development

ALALC Associação Latino-Americana de Livre Comércio

BCB Banco Central do Brasil

BID Banco Interamericano de Desenvolvimento

BIRD Banco Mundial (Banco Internacional para Reconstrução e

Desenvolvimento)

BNDE Banco Nacional de Desenvolvimento Econômico

BNH Banco Nacional de Habitação

BRICs Brasil, Rússia, Índia e China

CACEX Câmara de Comércio Exterior

CDI Comissão de Desenvolvimento Industrial

CECLA Comissão Especial de Coordenação Latino-Americana

CEE Comunidade Econômica Europeia

CEPAL Comissão Econômica para a América Latina

CESP Cia. Energética de São Paulo

CIP Comissão Interministerial de Preços

CMBEU Comissão Mista Brasil-Estados Unidos para o Desenvolvimento

Econômico

CMN Conselho Monetário Nacional

CEXIM Carteira de Exportação e Importação

DSN Doutrina de Segurança Nacional

ESG Escola Superior de Guerra

EUA Estados Unidos da América

Eximbank Export-Import Bank of the United States

FBCF Formação Bruta de Capital Fixo

FED Federal Reserve Bank

FGTS Fundo de Garantia por Tempo de Serviço

FMI Fundo Monetário Internacional

FRE Fundo de Reaparelhamento Econômico

GATT General Agreement on Tariffs and Trade

G77 Grupo dos 77 
IEDI Instituto de Estudos para o Desenvolvimento Industrial

IIPND Segundo Plano Nacional de Desenvolvimento

IPCA Índice de Preços ao Consumidor

IPEA Instituto de Pesquisa Econômica Aplicada

IPND Primeiro Plano Nacional de Desenvolvimento

ISEB Instituto Superior de Estudos Brasileiros

ISI Industrialização por Substituição de Importações

ITT International Telephone\&Telegraph

LTN Letra do Tesouro Nacional

MDIC Ministério do Desenvolvimento, Indústria e Comércio Exterior

MF Ministério da Fazenda

MIC Ministério da Indústria e Comércio

MP Ministério do Planejamento

MRE Ministério das Relações Exteriores

OEA Organização dos Estados Americanos

OIT Organização Internacional do Trabalho

ONU Organização das Nações Unidas

OPA Operação Pan-Americana

OPEP Organização dos Países Exportadores de Petróleo

ORTN Obrigação Reajustável do Tesouro Nacional

PAEG Programa de Ação Econômica do Governo

PEB Política Externa Brasileira

PED Programa Estratégico de Desenvolvimento

PEI Política Externa Independente

PIB Política Internacional do Brasil

PIIEB Política de Inserção Internacional da Economia Brasileira

STN Secretaria do Tesouro Nacional

SUMOC Superintendência da Moeda e do Crédito

TNP Tratado de Não Proliferação Nuclear

UME Unidade Monetária Europeia

UNCTAD Conferência das Nações Unidas sobre Comércio e Desenvolvimento

USAID Agência para o Desenvolvimento Internacional

URSS União das Repúblicas Socialistas Soviéticas 


\section{SUMÁRIO}

INTRODUÇÃO

\section{PARTE I: OCAPITALISMO COMO SISTEMAHISTÓRICO MUNDIAL E A DEPENDÊNCIA EXTERNA DA ECONOMIA BRASILEIRA ............................. 24}

Capítulo 1: A economia-mundo capitalista: Um conceito, várias perspectivas 25

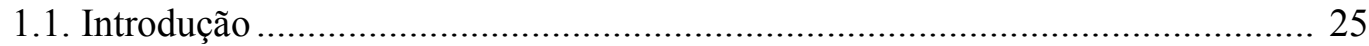

1.2.Conceitos, sistemas sociais e seus contextos ................................................. 28

1.3.O capitalismo como lugar e a acumulação "flexível" ...................................... 32

1.4. A hierarquia tripartite da economia-mundo capitalista .................................. 37

1.5. Os ciclos sistêmicos de acumulação e a geopolítica do capitalismo................... 46

1.6.Síntese: Lapidando as categorias ................................................................. 54

Capítulo 2: Autonomia e dependência internacional da economia brasileira: Enfoque

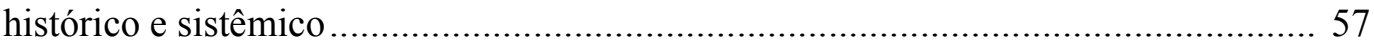

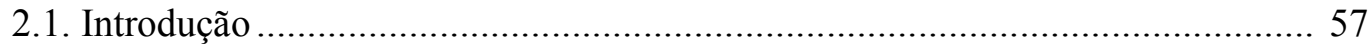

2.2.O Brasil e a inserção internacional de sua economia: Um estilo de pensamento,

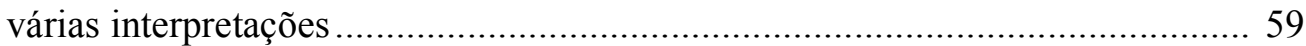

2.2.1. A visão sistêmica: $O$ peso dos determinantes externos........................... 60

2.2.2. O potencial do mercado interno....................................................... 66

2.2.3. Desenvolvimento e industrialização: Endogeneizando os mecanismos de acumulação ou aprofundando a dependência? ....................................... 74

2.3. Síntese: Três interpretações sobre a industrialização brasileira......................... 93

Capítulo 3: O papel da política externa: A diplomacia do desenvolvimento .............. 99

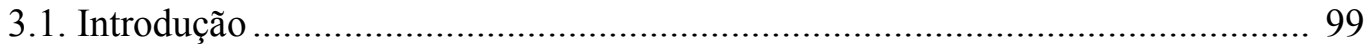

3.2.A evolução institucional do Itamaraty e as mudanças no contexto internacional: forjando uma tradição de política externa ................................................... 103

3.3.Os paradigmas "americanista" e "globalista" ................................................. 107

3.4. Síntese:A política externa como instrumento do desenvolvimento ................... 122 
PARTE II: O BRASIL NO CICLO SISTÊMICO DE ACUMULAÇÃO CAPITALISTA AMERICANO: O PAPEL DA POLÍTICA EXTERNA E DA POLÍTICA

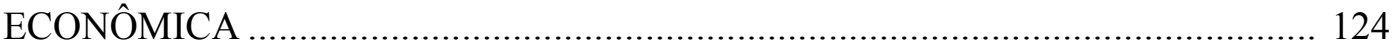

Capítulo 1: O ciclo sistêmico de acumulação capitalista americano e a geopolítica da Guerra Fria. 125

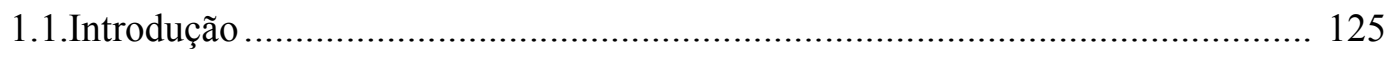

1.2.De Londres a Washington: Duas depressões e duas guerras mundiais ............... 127

1.3.Bretton Woods e a Guerra Fria: O auge do capitalismo das transnacionais norte-

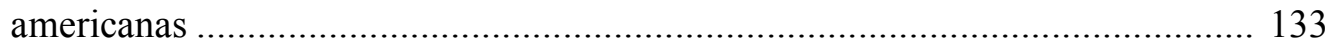

1.4.A expansão financeira dos anos 1970 .......................................................... 141

1.5.Síntese: O "longo século XX” e o Brasil.................................................... 147

Capítulo 2: O papel da política econômica e da política externa na inserção

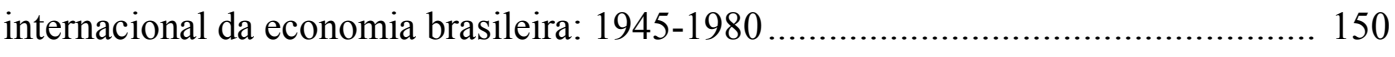

2.1.Introdução e conceitos fundamentais ............................................................. 150

2.2.O governo Dutra (1946-1950): A dependência e a aliança norte-americana ........ 156

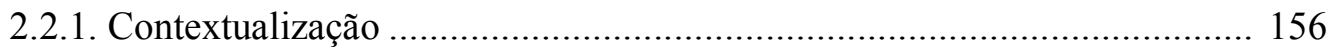

2.2.2. Instrumentos da política econômica ....................................................... 159

2.2.3. Instrumentos da política externa........................................................ 163

2.2.4. Comparação e resultados ................................................................ 165

2.3.O segundo governo Vargas (1950-1954): A velha fórmula sob nova equação - mais autonomia, menos dependência .......................................................... 168

2.3.1. Contextualização ..................................................................... 168

2.3.2. Instrumentos da política econômica ................................................ 169

2.3.3. Instrumentos da política externa................................................... 173

2.3.4. Comparação e resultados ................................................................ 177

2.4. O governo Kubistchek (1956-1961): A nova dependência como constrangimento

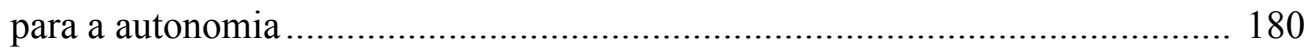

2.4.1. Contextualização ....................................................................... 180

2.4.2. Instrumentos da política econômica .................................................. 182

2.4.3. Instrumentos da política externa................................................... 186

2.4.4. Comparação e resultados ............................................................. 190 
2.5. Os governos Quadros e Goulart (1961-1964):A autonomia da política externa frustrada pelas consequências do desenvolvimento dependente 193

2.5.1. Contextualização 193

2.5.2. Instrumentos da política econômica 194

2.5.3. Instrumentos da política externa 197

2.5.4. Comparação e resultados 204

2.6. A constituição do Regime Militar (1964-1967): A negação da autonomia pela interdependência hemisférica .............................................................. 207

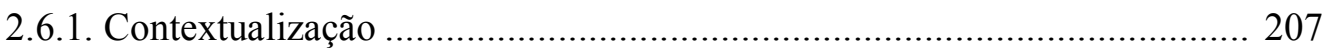

2.6.2. Instrumentos da política econômica ..................................................... 210

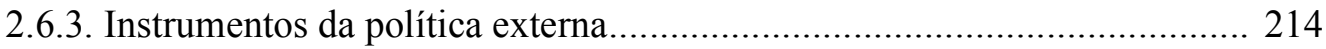

2.6.4. Comparação e resultados ................................................................... 218

2.7. Recrudescimento e transformação do Regime Militar (1967-1979): A autonomia pela redefinição da dependência em meio à crise do ciclo sistêmico de acumulação norte-americano .................................................................. 221

2.7.1. Contextualização ..................................................................... 221

2.7.2. Instrumentos da política econômica ................................................ 225

2.7.3. Instrumentos da política externa........................................................ 234

2.7.4. Comparação e resultados .................................................................... 251

Capítulo 3: Revisitando a "autonomia na dependência" ........................................ 256

3.1. Síntese dos instrumentos dos dois eixos da PIIEB: Formas de interação e

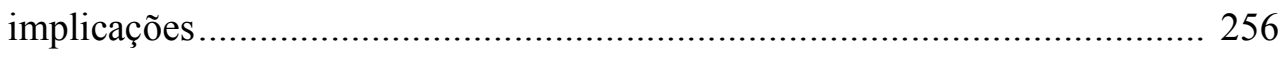

3.2. Análise empírica: A evolução dos dados estatísticos do período ..................... 266

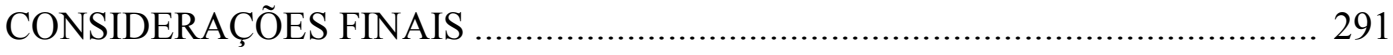

REFERÊNCIAS BIBLIOGRÁFICAS ............................................................ 297 


\section{INTRODUÇÃO}

Ao buscar entender o processo de formação da economia brasileira, suas estruturas e dinâmicas, e partindo da noção de sistema "centro-periferia" construída por Raúl Prebisch, Celso Furtado caracterizou e qualificou uma posição historicamente periférica do Brasil no sistema econômico internacional. Mesmo sobre outras roupagens e concepções, os estudos da natureza da relação entre metrópole e colônia, centro e periferia, ou entre países desenvolvidos e subdesenvolvidos, mostram que o Brasil dificilmente transitou ileso pelas grandes reformulações do sistema econômico internacional que se sucederam ao longo da sua história, tendo seus rumos afetados em graus variáveis, a depender da situação e das condicionantes vigentes.

Entretanto, no período entre 1945 e 1980, a economia brasileira passou por importantes transformações, tendo conseguido superar sua condição periférica, de mercado consumidor interno incipiente e estrutura produtiva essencialmente voltada à venda de primários para o exterior, para alçar-se a uma posição intermediária na hierarquia de poder econômico internacional. Nessa nova posição, semiperiférica, o Brasil passou a inserir-se como país de economia complexa e industrializada, porém ainda subdesenvolvido, tecnológica e financeiramente dependente do exterior, além de marcado por profundas desigualdades sócio regionais e econômicas. Embora tenha permanecido vulnerável a elementos do exterior, tendo apenas redefinido seus laços de dependência sobre novas formas, a economia brasileira adquiriu, nesse período, um crescente dinamismo econômico, tornando-se cada vez mais capaz de sustentar seus próprios ciclos de acumulação de capital e atuar de modo mais autônomo em prol de seus interesses no cenário internacional.

Em que medida o Estado brasileiro, por meio de suas políticas econômica e externa, contribuiu ou não para essa alteração do padrão de inserção internacional da economia brasileira?Qual foi o papel de cada um desses dois eixos de política governamental, que a despeito de serem ações conduzidas em âmbitos diferentes do poder público, com naturezas distintas e processos decisórios particulares, estiveram conectados pelo objeto comum da inserção internacional da economia brasileira? Houve coerência entre os instrumentos desses dois eixos? Como foi o poder de intervenção 
dessas políticas sobre o padrão de inserção internacional da economia brasileira diante do quadro de condicionantes internacionais e domésticos que se configurou ao país a cada momento histórico? Quais foram as suas implicações em termos de redefinição dos elementos de autonomia e dependência da economia brasileira no sistema internacional?

Tendo em vista esse conjunto de indagações, esta dissertação visa a avaliar o papel da ação governamental para as mudanças no padrão de inserção internacional da economia brasileira no período de 1945 a 1980, principalmente no âmbito de sua política econômica e de sua política externa. Objetiva ainda avaliar como se deu a interação entre os instrumentos desses dois eixos da política governamental, e as suas implicações em termos de ganho de autonomia ou dependência da economia brasileira no cenário internacional.

O peso do governo na determinação dos rumos do país variou ao longo da história, mas não pode ser negligenciado, devendo manter-se consciente da sua função inerentemente estratégica. Nesse sentido, a sua adequação e efetividade pesaram não só no enfrentamento dos desafios externos, como também no preparo e construção de caminhos para o futuro. Desse modo, o foco na ação governamental se justifica pela importância estratégica do Estado na determinação dos rumos do país, tanto na condução do desenvolvimento econômico nacional quanto na sua atuação nas arenas internacionais. E o interesse pelas formas de interação entre a política econômica e a política externa dá-se pela centralidade desses instrumentos do Estado no tratamento da inserção internacional da economia brasileira que, a despeito de serem ações conduzidas em âmbitos diferentes do poder público, evidenciam por meio da avaliação de suas naturezas alternativamente complementares ou contraditórias, e em diversos graus, a eficácia da ação estatal na consecução do seu projeto de governo.

Para avaliar o papel, as formas de interação e as implicações dos instrumentos de atuação desses dois eixos de atuação do Estado - a política econômica e a política externa- para a alteração do padrão de inserção internacional da economia brasileira, a dissertação propõe o conceito de política de inserção internacional da economia brasileira (PIIEB), cuja natureza será detalhada com mais precisão ao longo deste trabalho, mas que para fins introdutórios pode ser entendida como toda ação ou projeto desenvolvido e implementado por agentes governamentais com vistas a produzir algum efeito na inserção internacional da economia brasileira.

Essa política, e os dois grandes eixos que a compõem - a política econômica e a política externa -, foi conformada em sua construção por diversos elementos estruturais 
e conjunturais, decorrentes do sistema econômico mundial e das orientações domésticas vigentes a cada momento histórico. As diferentes aberturas e possibilidades determinadas pela variação desses elementos no tempo podem ajudar a explicar os feitios variáveis apresentados pelos instrumentos da PIIEB ao longo do período estudado, e porque os seus dois eixos de atuação se movimentaram às vezes em sincronia e às vezes de forma independente, freqüentemente aparentando incoerência entre si, e com diferentes implicações para a inserção internacional da economia brasileira.

Ou seja, a abordagem dessas questões não pode prescindir da compreensão da lógica de funcionamento do sistema capitalista mundial no qual a economia brasileira se insere, e de como os elementos da esfera externa interferem ou influenciam nos rumos do seu desenvolvimento. Deve abarcar ainda as possibilidades e limitações determinadas pelas estruturas domésticas do país, e como elas se inter-relacionam dinamicamente com o panorama sistêmico internacional.

Diante desse conjunto de considerações, a estrutura da dissertação foi dividida em duas partes, além da introdução e das considerações finais: a primeira essencialmente teórico-conceitual, visando a abarcar um arcabouço teórico compreensivo sobre os elementos do sistema internacional e da economia brasileira que conformaram o cenário de atuação da política de inserção internacional da economia brasileira, além de formulações referentes ao papel da política econômica e da política externa como instrumentos para a construção de uma inserção internacional diferente da economia brasileira; e a segunda fundamentalmente analítica, em que as ações da política de inserção internacional da economia brasileira, as formas de interação estabelecidas entre os instrumentos dos seus dois eixos de atuação e as suas implicações para o padrão de inserção internacional da economia brasileira são analisados.

Sumariamente, a primeira parte divide-se em três capítulos. O primeiro capítulo destina-se a abarcar a estrutura hierárquica e lógica evolutiva do sistema capitalista mundial por meio do arcabouço teórico da "economia-mundo capitalista" e abordagens relacionadas, visando a edificar um instrumental teórico-conceitual de como economias periféricas como o Brasil se inserem na economia mundial e se relacionam com suas diferentes partes de modo dinamicamente evolutivo ao longo da história. Isto é feito principalmente por meio das formulações de Arrighi (1990, 1996, 2008), Braudel (1996)e Wallerstein (2000). 
Já o segundo capítulo analisa as visões de pensadores brasileiros de como entender a economia brasileira e suas transformações a partir de uma combinação de fatores endógenos e exógenos, restabelecendo a difícil ponte inter-relacional entre a nossa história econômica e a do sistema capitalista mundial.Os autores aqui utilizados são Caio Prado Júnior (1985, 1989, 2004), Celso Furtado (1965, 1974, 2000) e Ignácio Rangel (1957, 1955, 1986).

E o último capítulo da primeira parte proporciona uma visão alternativa de como o problema da inserção internacional da economia brasileira foi pensada por estudiosos da política externa brasileira, e como esta foi se configurando como um instrumento do desenvolvimento nacional e da construção de uma inserção mais favorável para o país. Os principais autores utilizados foram Lima (2005), Lima e Hirst (2006), Lima e Moura (1982), Moura (1980), Pinheiro (2004), Rodrigues (1966), e Visentini (2008).

Realizada essa fundamentação teórica e identificados os elementos conceituais que conformaram o cenário de atuação da política de inserção internacional da economia brasileira, a segunda parte da dissertação trata da análise propriamente dita desta política, dos instrumentos de seus dois eixos de atuação e de suas implicações. Também dividida em três capítulos, o primeiro capítulo inicia introduzindo a lógica de funcionamento do ciclo sistêmico de acumulação norte-americano que regeu e caracterizou a evolução do capitalismo mundial no período entre 1945 e 1980, e com o qual a economia brasileira manteve uma relação de "autonomia na dependência", alternativamente intensificando ou afrouxando os seus laços de subordinação à potência hegemônica.Os referenciais utilizados foram Arrighi (1996), Eichengreen (2000), Gilpin (2000), Hobsbawm (1994, 1999) e Kindleberger (1990).

Em seguida, o segundo capítulo procede à análise propriamente dita dos elementos da política econômica e da política externa que trabalharam em prol de uma mudança da inserção internacional da economia brasileira, buscando ainda confrontar as orientações predominantes que emanaram dos instrumentos desses dois eixos, e identificar qual foi a relação entre ambos em termos de implicações sobre o padrão de inserção internacional da economia brasileira.Aqui, foram consultadas fontes como Abreu ETAL (1990), Amado (1996), Castro e Souza (1988), Cervo e Bueno (2008), Evans (1980), Hirst (1990), Lima (1990), Lima e Moura (1982), Love (1998), Malan ETAL (1977), Martins (1975), Moura (1980, 1991), Pinheiro (2004), Rodrigues (1966, 1982), Singer (1989), Tavares (1975, 2010) e Visentini (2008). 
Por fim, o último capítulo da parte II sintetiza os instrumentos dos dois eixos da política de inserção internacional da economia brasileira, as formas de interação desenvolvidas entre ambos e as alterações ocorridas no padrão de inserção internacional da economia brasileira tendo em vista os deslocamentos do sistema capitalista mundial, as transformações da própria economia brasileira e a atuação da PIIEB. Procede ainda a uma análise dos dados estatísticos sobre a evolução da economia brasileira no período, com o intuito não de comprovar relações de causalidade entre as variáveis estudadas, mas apenas de ilustraras transformações ocorridas sobre a estrutura produtiva brasileira e a sua inserção internacional entre 1945 e 1980.

Desse modo, pretende-se responder às perguntas inicialmente colocadas nesta introdução, principalmente, à indagação: qual foi o papel da política econômica e da política externa para a alteração do padrão de inserção internacional da economia brasileira entre 1945 e 1980?E será o conceito proposto de politica de inserção internacional da economia brasileira capaz de responder a essa pergunta e outras questões relacionadas?

Finalmente, cabe apontar que, originalmente, este trabalho pretendia abarcar o período inteiro entre o fim da Segunda Guerra Mundial e os anos 2000, visando a analisar o papel da política econômica e da política externa para as alterações do padrão de inserção internacional da economia brasileira ocorridos durante todo esse período. Em especial, buscava-se elucidar o papel do Estado para a mudança no padrão de inserção internacional da economia brasileira evidenciado pela última grande crise mundial de 2008, pela qual o país conseguiu transitar com relativa tranquilidade em comparação com as dificuldades enfrentadas por grande parte do mundo desenvolvido.

No entanto, ao longo do desenvolvimento da dissertação, foi-se evidenciando a necessidade um maior aprofundamento nas teorias, conceitos e metodologias próprias das áreas de conhecimento tocadas pelo tema da pesquisa, alargando não só a parte conceitual do trabalho, mas também a analítica. A solução foi limitar o período estudado até 1980, deixando os demais anos para futuras pesquisas. Apesar do recorte, o intervalo de 1945 a 1980 foi crucial para a formação e consolidação do parque industrial nacional, tendo sido um período em que se produziu uma transformação fundamental do padrão de inserção internacional da economia brasileira em direção a uma economia industrializada e subdesenvolvida da semiperiferia capitalista mundial.

Destarte, espera-se que a análise a ser desenvolvida nesta dissertação e o seu conceito proposto de política de inserção internacional da economia brasileira 
mostrem-se capazes de extrapolar os limites do horizonte temporal aqui abordado, de modo a oferecer instrumentos úteis para a produção de análises dos períodos posteriores, como os governos de Fernando Henrique Cardoso e Luiz Inácio Lula da Silva.Principalmente, tendo em vista os importantes movimentos de alteração do mapa econômico mundial, acelerados a partir da eclosão em 2008 da maior crise econômica de proporções mundiais desde a Crise de 1929, o estudo de tais dimensões se mostra estratégico e crucial para os rumos do desenvolvimento da economia brasileira. Apesar de não serem forças novas, estando em desenvolvimento há anos, a crise e suas consequências recolocaram, em caráter prioritário, esses fatores na mesa de discussões, acendendo uma luz de alerta sobre a séria necessidade de uma avaliação das suas implicações para o Brasil.

As transformações do sistema econômico mundial e a possível gestação de uma nova ordem internacional têm sido objeto de intensos debates e discussões. A manutenção de uma surpreendente expansão pela economia chinesa nas últimas décadas já vinha indicando a emergência de uma nova potência econômica. A criação e popularização do acrônimo "BRICs" (Brasil, Rússia, Índia e China) no início deste século, destacando o rápido crescimento desses quatro países em desenvolvimento, veio a enfatizar essa ampliação do horizonte de novos centros de influência econômica. E, por fim, os despojos da maior crise mundial desde a Grande Depressão evidenciaram a perspectiva de uma lenta recuperação para a maior parte do mundo desenvolvido, com expectativas de anos de baixo crescimento.

Esses movimentos parecem indicar um deslocamento parcial do centro de dinamismo econômico mundial dos países desenvolvidos para os países em desenvolvimento, ou ao menos, uma redistribuição de pesos.Particularmente, o desempenho nacional no decorrer da crise de 2008 foi no geral positivamente avaliado ao redor do mundo. Ao contrário das tradicionais potências desenvolvidas, e de experiências nacionais passadas, o Brasil saiu rapidamente da crise internacional com a economia aquecida, o desemprego decrescente, o panorama macroeconômico estável e o sistema bancário sólido.

Mesmo assim, acenderam-se sinais de alerta. Alguns desdobramentos levantaram apreensões, como por exemplo, sobre a crescente vulnerabilidade externaespecialmente no que diz respeito ao crescente financiamento por meio de capitais externos de curto prazo- e o aprofundamento da sobrevalorização em termos reais da moeda brasileira. São comuns também as preocupações sobre a "reprimarização" da 
nossa pauta exportadora, a "desindustrialização" da estrutura produtiva brasileira e a ocorrência da "doença holandesa" no Brasil.

Evidentemente, as possíveis decorrências para o Brasil são amplas e variadas, constituindo extensos e profícuos objetos de debate e investigação. $\mathrm{Na}$ verdade, no mundo inteiro, além das implicações concretas desta reestruturação sistêmica expressas por dados estatísticos como os de atividade, comércio e finanças internacionais, também as bases ideológicas da orientação político-econômica dominante foram desta vez profundamente abaladas. Ou seja, não se trata apenas de um processo de reestruturação da economia mundial, mas também de ruptura de paradigmas, permitindo a reavaliação dos limites e oportunidades para uma melhor inserção internacional da economia brasileira.

Como bem alertou Castro (2008, p. 1): "Não é a primeira vez que o centro de gravidade do crescimento da economia mundial se desloca. [...] deslocamentos desse tipo, raros na história, têm enormes implicações”. Ao longo da sua relativamente curta história, o Brasil se deparou com significativas reformulações da ordem econômica internacional, e as influências destas alterações externas sobre os rumos do país e da sua integração na economia mundial dependeram em muitos aspectos das ações governamentais. Aliadas à estrutura socioeconômica doméstica e às suas potencialidades, estas em cada período permitiram ao país maior ou menor flexibilidade no tratamento das restrições e oportunidades que lhe iam sendo colocadas pelo sistema internacional.

Reforça-se, assim, a importância de uma avaliação das ações de política econômica e política externa conduzidas pelo governo ao longo da evolução histórica brasileira em face aos desafios e oportunidades colocados pelo sistema internacional, e do seu poder de intervenção em termos de produção de um padrão de inserção internacional diferente para a economia brasileira. Espera-se, desse modo, que a análise desenvolvida nessa dissertação sobre o papel da política econômica e da política externa para as transformações do padrão de inserção internacional da economia brasileira entre 1945 e 1980 seja capaz de proporcionar a indicação de novos caminhos para análises semelhantes dos períodos posteriores. 


\section{PARTE I \\ O CAPITALISMO \\ COMO SISTEMA HISTÓRICO MUNDIAL \\ E A DEPENDÊNCIA EXTERNA DA \\ ECONOMIABRASILEIRA}




\section{CAPÍTULO 1}

\section{A ECONOMIA-MUNDO CAPITALISTA: UM CONCEITO,VÁRIAS PERSPECTIVAS}

\subsection{INTRODUÇÃO}

O objetivo deste capítulo é identificar os horizontes colocados pelo sistema capitalista mundial ao longo de seu desenvolvimento histórico a economias não pertencentes ao chamado "mundo desenvolvido", como a brasileira, especialmente no que diz respeito a sua capacidade de exercer maior autonomia sobre os rumos de seu desenvolvimento econômico. Para tais fins, torna-se indispensável abordar a lógica de funcionamento do capitalismo como sistema político-econômico de alcance mundial, visando a delinear algumas ferramentas de análise úteis à compreensão da transformação do panorama econômico internacional no período definido como objeto desta pesquisa e de como a economia brasileira conseguiu se adaptar ao desenrolar dessa conjuntura internacional.

Primeiramente, é preciso atentar a certos cuidados metodológicos com o intuito de identificar e evitar anacronismos e ambiguidades, como o estudo diacrônico e contextualizado dos conceitos e ideias, a questão da definição da unidade de análise adequada à investigação científica e outras considerações essenciais de ordem históricogeográfica. Tendo em vista tais cuidados, buscou-se aprofundar o conceito de capitalismo veiculado por Braudel (1996) e Arrighi (1996), e desenvolvido de modo particular por Wallerstein (2000), Brenner (1977) e Harvey (2005), evidenciando duas “dimensões" essenciais desse fenômeno: uma temporal e outra espacial. É importante ressalvar serem duas dimensões que se interpenetram, uma não se explicando adequadamente sem a outra, sendo tão intimamente inter-relacionadas que a sua separação apenas se justifica como recurso analítico cujo intento é facilitar a compreensão da totalidade.

Destarte, o desenvolvimento deste capítulo teórico-introdutório se desenrolará em mais quatro partes. Na primeira, pretende-se mostrar a importância de algumas preocupações acerca do uso dos termos e conceitos necessários à construção de uma análise sistêmica, sem desligá-los dos seus agentes e ambientes histórico-geográficos. 
Neste sentido, as referências intelectuais consistem nos argumentos de Koselleck (2006) e de Skinner (1969), também sendo abordadas as visões pautadas no "ponto de vista da totalidade" e da "longa duração histórica" desenvolvidas por Braudel (1996) e Wallerstein (2000).

A segunda parte traz a definição do capitalismo como o lugar da alta acumulação do capital, elaborada por Braudel (1996) e desenvolvida de modo particular por Arrighi (1996), que se contrapõe às interpretações tradicionais da economia neoclássica. Em seguida, serão abordadas a sua "dimensão espacial", descrita por meio da hierarquia de poder político-econômico entre países e regiões que caracteriza a "economia-mundo capitalista" desenvolvida por Wallerstein (2000) e pela dinâmica geopolítica do capitalismo estudada por Harvey (2055); e a sua "dimensão temporal", desenvolvida por meio dos ciclos sistêmicos de acumulação capitalista de Arrighi (1996), que apontam para um padrão cíclico de evolução histórica do capitalismo,evidenciando a instabilidade e maleabilidade que caracterizou essas hierarquias, apesar do ritmo lento das mudanças.

Ao longo dessas seções ficará evidente a existência de vários debates entre esses autores, como o que o capitalismo "braudeliano" suscita com a visão de Wallerstein (2000), Brenner (1977) e Harvey (2005). Além de comporem discussões importantes para o estudo da dinâmica e evolução do capitalismo, esses diálogos abrem espaço para a reflexão sobre como a lógica da economia-mundo capitalista pode afetar a posição e o destino das economias que integram a sua periferia, como o Brasil.

Nesse sentido, cabe ressaltar que, conforme será desenvolvido no próximo capítulo, a discussão dessas questões a partir da perspectiva das economias periféricas latino-americanas foi anterior a essas formulações sobre a economia-mundo capitalista, que são pensadas a partir de seu centro de dinamismo. Ao estudar a história das ideias econômicas na América Latina, Love (1996, p. 207-208) aponta que, apesar dos pensadores latino-americanos no geral tenderem a adaptar as teorias e ideias europeias para explicar fenômenos de seus países, no intervalo de meio século entre a Grande Depressão e os anos 1980alguns desses intelectuais produziram ideias "autônomas" e de grande originalidade sobre o papel e a condição de seus países no sistema capitalista internacional.É o caso do estruturalismo da Cepal e da "teoria da dependência", cuja influência e alcance extrapolaram as fronteiras latino-americanas, tendo sido inclusive aproveitadas pelas formulações de economia-mundo desenvolvidas mais tarde pelos pensadores norte-americanos e europeus aqui tratados. 
O significado dessa originalidade latino-americana pode ser melhor dimensionada diante da "universalidade" alcançada pelo pensamento europeu apontada por Chakrabarty (2007, p. 27-28), cujas ideias e conceitos (como cidadania, Estado, indivíduo, democracia, soberania, justiça social e racionalidade científica) tornaram-se um referencial implícito a ser seguido pela comunidade científica mundial.Tendo em vista serem formulações originadas e desenvolvidas a partir de contextos próprios e específicos europeus, o autor questiona se a sua comum transposição como canais explicativos de outras realidades estranhas à europeia seria adequada ou conduziria a falsas interpretações.Em suas palavras: "Como o pensamento se relaciona com o lugar? Podem pensamentos transcender o seu lugar de origem? Os lugares deixam sua marca no pensamento [...]?" (CHAKRABARTY, 2007, p. xiii).

Por exemplo, no caso da história, o autor constata que no "discurso acadêmico sobre a história" (a história como um discurso produzido na instituição da universidade), a história européia é soberana sobre as histórias dos demais países do mundo, glorificada como o berço do moderno e um parâmetro silencioso do conhecimento histórico.As "demais histórias" seriam suas "subalternas". Em consequência, produziu-se uma "ignorância assimétrica" entre historiadores europeus e historiadores do Terceiro Mundo:enquanto estes tendem a referir-se ao pensamento histórico europeu ao analisar seus países, aqueles trabalham e produzem seus modelos de análise em relativa ignorância das histórias não europeias.(CHAKRABARTY, 2007, p. 28-29)

O autor enfatiza que essa "ignorância assimétrica" não é restrita aos historiadores, nem retira o mérito daqueles que a praticam, uma vez que inúmeros pensadores influentes produziram por gerações teorias importantes em relativa (às vezes absoluta) ignorância da maior parte da humanidade, ou seja, das culturas não europeias. Mesmo assim, não deixa de ser um grande paradoxo o fato dos pesquisadores do Terceiro Mundo acreditarem nas teorias "europeias", relativamente ignorantes das realidades periféricas, como parâmetros para entender suas sociedades.

Para o autor, a explicação advém de um extenso processo histórico em que a "universalidade" do pensamento europeu foi incutida ao longo de séculos nas sociedades não europeias por meio da força e do discurso, perpetuados primeiro pelo imperialismo europeu nas colônias, seguido pelos movimentos nacionalistas no Terceiro Mundo e, por fim, pelos discursos acadêmicos construídos nas universidades.Destarte, a "tradição intelectual europeia" alcançou ampla difusão e aceitação, com profundas 
consequências na evolução das ciências sociais em todo o mundo e tornando-se a única "viva" na maioria das faculdades de ciências sociais existentes(CHAKRABARTY, 2007, p. 5).

Em certa medida, esse fenômeno se expressa nas formulações latino-americanas pós-Segunda Guerra às quais nos referimos, uma vez que foram ideias concebidas a partir da análise das relações entre a periferia e o sistema internacional em que ela se insere. Isto é, constituem expressão de que a periferia não consegue pensar sua situação sem abordar o todo do qual faz parte e sem o qual não existe - ao contrário do centro, que parte da sua situação para pensar o todo, o qual ajudou a formatar.Porém, no que diz respeito ao uso das concepções desenvolvidas pelos europeus a partir de suas próprias realidades, essas formulações latino-americanas escapam à "armadilha universalizante europeia", ao realizarem análises criteriosas das especificidades históricas de seus países, produzindo explicações originais acerca dos processos de desenvolvimento e subdesenvolvimento da periferia. Em especial, no caso dos autores adiante tratados - Caio Prado Jr., Celso Furtado e Ignácio Rangel -, todos criticam a mera transposição das teorias e modelos europeus para explicar a realidade brasileira, tendo em vista ser uma estrutura socioeconômica e historicamente determinada de modo bastante específico e diverso das estruturas europeias e que, portanto, deve ser objeto de suas próprias teorias e modelos, de modo a contemplar todas as suas especificidades.

\subsection{CONCEITOS, SISTEMAS SOCIAIS E SEUS CONTEXTOS}

As palavras podem permanecer sempre as mesmas, mas os seus sentidos se alteram conforme o contexto, o agente, o lugar e a época. Da mesma forma, os conceitos podem possuir diversas nuances e mudar de conteúdos - de tal sorte que sua compreensão e uso adequado requerem a apreensão dos ambientes histórico-sociais em que o conceito surgiu e evoluiu, por quem foi criado e usado, e com quais finalidades. Portanto, os conceitos unem experiências - passadas, presentes e possíveis -, revelando estruturas com referencial empírico e duração ${ }^{1}$, justificando assim a necessidade de se atentar à sua aplicação para compor a análise investigativa.

${ }^{1}$ Esta é a ideia por trás da "História dos Conceitos", campo multidisciplinar desenvolvido por Koselleck (2006, p. 110-114) que visa a estudar a semântica histórica dos conceitos (Begriffsgeschichte) e sublinhar 
Segundo Koselleck (2006, p. 113-115), conceitos refletem contextos extralinguísticos, concretizando em si uma generalização e contendo diversos significados que independem do seu uso em um momento específico. Neste sentido diferem das palavras,que apesar de também se referirem a contextos extralinguísticos, têm seu significado determinado pela sua utilização, só virando conceito quando todos os seus empregos forem incorporados a ela - os conceitos já trazem "embutidos" em si contextos e conteúdos. Logo, se todo conceito é expresso por uma palavra, nem toda palavra é um conceito.

Porém, apesar de no geral os conceitos fundamentarem-se em fenômenos já existentes, eles também podem ser criados para indicar transformações em curso, por meio de processos de "resignificação" dos termos e de criação de neologismos. Desse modo, Koselleck (2006) considera que toda historiografia age em dois níveis: ou examina fatos já articulados linguisticamente ou reconstrói eventos ainda não $\operatorname{articulados}^{2}$. Assim, os conceitos carregam uma temporalidade de conjunturas que é de grande valor à ciência investigativa, pois abre as possibilidades de revelar

um ponto de vista polêmico orientado para o presente, assim como um componente de planejamento futuro, ao lado de determinados elementos de longa duração da constituição social originados no passado [...]. Na multiplicidade cronológica do aspecto semântico reside, portanto, a força expressiva da história. (KOSELLECK, 2006, p. 101)

Alternativamente, Skinner (1969) também reconhece a riqueza denotativa dos conceitos e sublinha a relevância da compreensão dos ambientes e fatos que os envolvem. Porém, sua qualificação vai mais além ao criticar as abordagens pautadas no estudo de "conceitos fundamentais", ideias cuja perenidade e universalidade a elas atribuídas trazem implícitas uma suposta independência dos seus contextos temporais, intelectuais e sociais. De modo semelhante à crítica pós-colonialista de Chakrabarty (2007) feita décadas depois, Skinner avalia que a abrangência absoluta imputada a alguns conceitos acaba por gerar uma tendência a atribuir intenções e significados inexistentes a autores e obras, que não os tiveram, nem poderiam ter tido, em seus ambientes de origem.

a necessidade de se deter sobre os diferentes significados associados a um termo ao longo da História. Ou seja, é o estudo da história da terminologia relevante à investigação histórica, na medida em que esta usa textos e documentos para averiguar e deduzir as circunstâncias, fatos e estruturas históricas.

${ }^{2} \mathrm{Na}$ realidade, Koselleck (2006) identifica três processos principais de evolução dos significados de um conceito: os tradicionais, cujos significados permaneceram ao longo do tempo; os que, apesar de manterem o mesmo vocábulo, mudaram de significado tão radicalmente que só podem ser entendidos historicamente; e os neologismos, criados para expressar processos inéditos. 
Conceitos e argumentos tomados sem a devida consideração dos significados originalmente idealizados pelos seus autores e usuários podem acabar por resultar no que Skinner (1969) considera serem absurdidades, narrações de pensamentos inexistentes, erros por ele chamados de “mitologias"históricas ${ }^{3}$. Para o autor, a dificuldade de se delinear pensamentos sem definir critérios conhecidos, abordar fenômenos sem contaminá-los com pré-conceitos e expectativas, ou conectar as manifestações de um evento sem identificar semelhanças com experiências anteriores vem a exacerbar o problema. "Nós precisamos classificar para entender, e só podemos classificar o desconhecido em termos do que é familiar." (SKINNER, 1969, p. 58).

Deste modo, Skinner (1969) aponta dois requisitos metodológicos mínimosàs investigações científicas: nenhum pensador pode ter dito ou querer ter dito algo que era impossível no seu tempo e contexto; e a pesquisa não pode ser reduzida a uma atividade padronizante, pois não se trata de simplesmente manipular ideias ou encaixá-las em teorias. Para o autor, as generalizações carregam consigo o perigo latente de não corresponderem adequadamente aos eventos individuais que pretendem representar, pois:

Qualquer discurso é inescapavelmente a expressão de uma intenção particular, em uma ocasião particular, direcionada à solução de um problema particular, e, portanto específico ao seu contexto [...] não existem problemas perenes na filosofia. Existem apenas respostas individuais a questões individuais. (SKINNER, 1969, p. 88)

Braudel (1996c), em contraste, desenvolve uma abordagem alternativa à defendida por Skinner. Apesar de também destacar a importância de se situar as realidades humanas conforme sua duração e local, o autor dá um peso especial à identificação dos padrões recorrentes no tempo e espaço, e das regularidades tendenciais que caracterizam os fenômenos históricos.

$\mathrm{Na}$ realidade, todos esses autores reconhecem os equívocos e ambiguidades potenciais do uso inadequado dos conceitos e enfatizam a importância do estudo dos seus contextos de gestação e desenvolvimento. Como Skinner (1969) e Koselleck (2006), Braudel (1996b) também destaca a necessidade da análise do surgimento e da evolução histórica dos conceitos a serem empregados na pesquisa científica: "as

\footnotetext{
3 Para ilustrar o argumento, Skinner (1969) destaca três "Mitologias": a "das doutrinas", em que a doutrina domina e determina a investigação histórica, levando a erros como atribuí-la a um autor ou texto que não poderia tê-la concebido ou abordado; a "da coerência", em que a falta de consistência nas ideias de um pensador são vistas como inconcebíveis, levando a uma busca exaustiva por uma coerência inexistente; e a "da prolepse", em que a expectativa de encontrar um significado específico determina a análise, levando a entender o sentido esperado em vez do sentido efetivo.
} 
palavras-chave do vocabulário histórico só devem ser utilizadas depois de interrogadas [...] De onde vêm elas? Como chegaram até nós?" (p. 201).

Porém, Braudel (1996b) aponta que deve haver laços e continuidades entre passado longínquo e tempo presente, persuadido do valor explicativo do longo prazo, e elegendo a sua escolha pela análise de "longa duração". Para o autor, confiar nos amplos recursos da História, no seu desenrolar cronológico e nas suas temporalidades, seria uma tentativa de "recorrer à prova das provas para confirmar ou infirmar as investigações" (BRAUDEL, 1996b, p. 7), porque só a História pode apresentar evidências que constituam: "uma explicação - uma das mais convincentes - e uma verificação, na verdade a única situada fora das nossas deduções abstratas, das nossas lógicas a priori, fora até das armadilhas que o bom senso não para de montar para nós" (p. 7).

É também neste sentido que Wallerstein (2000, p. 72-74) busca empreender sua investigação científica, por meio de uma abordagem histórica de "longo prazo" semelhante à de Braudel. Para ele, a ciência social não deve perder contato com a perspectiva histórica, pois só esta permite apreender as estruturas humanas e suas mudanças ${ }^{4}$, nem as partes devem ser isoladas do inteiro que as integra- defendendo, assim, um "ponto de vista da totalidade" que considera ser indispensável ao estudo das humanidades.Em sua visão, a ciência social a-histórica e descontextualizada constitui uma fonte abundante de anacronismos, razão pela qual o autor constrói o seu arcabouço teórico baseado no que chama de "totalidades históricas", propondo um modelo alternativo para realizar a análise comparativa dos fenômenos sociais.

Portanto, esses autores nos ensinam que a prevenção de enganos e controvérsias na análise científica requer alguns cuidados metodológicos essenciais. A investigação exaustiva e restrita dos termos e conceitos não resolve: a compreensão mais completa só é possível com informação externa a eles, pois seu significado e uso podem mudar conforme o espaço e o tempo. Deste modo, reforça-se a relevância do estudo da evolução das circunstâncias históricas dos conceitos, pois ao revelar possíveis disjunções entre significados e fatos relacionados ao mesmo vocábulo, são descobertas as camadas de significados, a estrutura e a profundidade histórica de um conceito ${ }^{5}$.

\footnotetext{
${ }^{4}$ Aqui, Wallerstein (2000, p. 72) amplia a problemática para criticar a disseminação de modelos abstratos e quantitativos que visam explicar o todo social sem abordá-los historicamente, mostrando que suas falhas são prontamente evidenciadas pela realidade empírica da História.

${ }_{5}^{5}$ É neste sentido que Koselleck (2006) aponta que, se a História dos Conceitos inicia pela análise sincrônica como estudo dos usos e significados contemporâneos do conceito (história do conceito
} 


\subsection{O CAPITALISMO COMO LUGAR E A ACUMULAÇÃO "FLEXÍVEL"}

A identificação dos padrões históricos de relacionamento da economia brasileira com o sistema capitalista - nosso objetivo central- deve, primeiramente, passar pela compreensão da lógica de funcionamento desse sistema. Desse modo, não se pode prescindir de abordar o que é o capitalismo, esse fenômeno que rege, ou pelo menos norteia, a maior parte das relações econômicas da economia mundial, e que como visto, é rodeado por uma miríade de significados que variam conforme as condições do momento histórico em que é empregado.

Capitalismo, nas palavras de Braudel (1996b), é uma palavra tão "ambígua, pouco científica e usada a torto e a direito [...], que seu uso só não seria eliminado pela falta de substituto melhor" (p. 199) ${ }^{6}$. O autor lembra que, apesar de no século XIX a palavra já ter sido usada com o sentido de "apropriação do capital por uns com exclusão dos outros" (p. 206), seu emprego era raro - sendo ignorada mesmo por Marx. Somente no início do século XX o vocábulo teria adquirido sua nuance política, sendo invocado como antônimo para socialismo.A partir de então, Braudel (1996b, p. 206) aponta que o termo vai ficando cada vez mais carregado de sentidos, ambiguidades e contradições:

De todos, os historiadores foram os mais seduzidos pela palavra nova [...]. Sem se preocuparem com anacronismos, abriram-lhe todo o campo da prospecção histórica, a antiga Babilônia e a Grécia helenística, a China antiga, Roma [...]. Os maiores nomes da historiografia recente estão implicados nesse jogo que viria a desencadear uma autêntica caça às bruxas.

Não há dúvidas, portanto, que se trata de um termo que foi incorporando ao longo do tempo conotações econômicas, sociais e políticas. Para o autor, é certo se tratar de um regime centrado no capital - conceito que, em sua concepção, a evidência empírica da história demonstra poder ser considerado tudo aquilo que entra nos circuitos econômicos para regressar trazendo mais de si mesmo, independente de estar

propriamente dito), é apenas com a análise diacrônica que ela se completa, com o estudo da duração e transformação dos significados em paralelo ao da duração e transformação do panorama político-social.

${ }^{6}$ Braudel (1996b) realiza uma detida investigação acerca dos vocábulos-chaves que no geral permeiam as análises sobre o capitalismo, visando a esclarecer a controvérsia gerada pelos seus inúmeros significados. Em particular, ele estuda a evolução histórica de três palavras, capital,capitalista e capitalismo, esta última a mais recente e polêmica das três. 
relacionado ou não às esferas produtivas. Ou seja, além dos usos relacionados à produção (como pagamento de insumos e salários utilizados no processo produtivo),o capital pode ser usado para estimular trocas comerciais ou realizar acordos financeiros, e quaisquer outros usos, desde que visando a multiplicar o capital inicial aplicado.

Tendo em vista este conceito de capital, Braudel (1996b, p. 215-217) situa o capitalismo como o lugar que, a cada momento, oferece a atividade econômica que permite a mais alta reprodução de capital. Além disso, o autor identifica que, na história do capitalismo, suas características essenciais sempre foram a "flexibilidade", a "capacidade de mudança e adaptação" e o "ecletismo" para transitar pelas mais diversas atividades econômicas conforme as oportunidades de lucro - e não as formas específicas e concretas assumidas em diferentes lugares e momentos. Destarte, o capitalismo assim definido teria existido desde tempos muito remotos, e apesar de em certos períodos parecer ter "se especializado" (como a atividade industrial no século XIX), na verdade a sua concentração em certa atividade econômica deve ser entendida como a escolha do "local" de maior dinamismo que naquele momento permitia a mais alta reprodução do capital.

Para Braudel (1996b, p. 207), a comum identificação do capitalismo com o modo de produção industrial teria sido resultado da ampla difusão alcançada por algumas análises reduzidas a uma "ortodoxia pós-marxista", segundo as quais não teria havido capitalismo antes da Revolução Industrial. Apesar de reconhecer a visão de Marx e Dobb do "capitalismo como o sistema em que ocorre a mercantilização do trabalho", relacionada ao capital aplicado à esfera da produção sobre relações de trabalho assalariado, Braudel (1996b, p. 206-208) considera ser esta apenas uma dentre várias manifestações do capitalismo. Em sua concepção, o "modo de produção industrial" ou o "trabalho livre e assalariado" não são particularidades essenciais e indispensáveis do capitalismo, mas sim a sua concentração no "lugar do investimento e da alta taxa de produção de capital”. Se o capitalismo permanecia restrito a determinadas atividades específicas antes de sua fase industrial, não estendendo sua influência para o resto da economia e não alcançando tamanha visibilidade, era porque lhe faltavam oportunidades de lucro mais atrativas.

Porém, o autor concede que, diante da popularização desta visão "pós-marxista", o advento da Revolução Industrial deve ter provocado alguma mutação no conteúdo da palavra capital (e capitalismo). Em sua pesquisa, ele chega à conclusão de que a Revolução Industrial representou "uma mutação do capital fixo, um capital desde então 
mais caro, porém muito mais duradouro e aperfeiçoado, que mudará radicalmente as taxas de produtividade" (BRAUDEL, 1996b, p. 215). Como nas economias antigas boa parte da formação de capital bruto não era durável (construções poucos resistentes, ferramentas frágeis), a formação de capital líquido era muito pequena e a taxa de reprodução do capital muito modesta. Isso teria tido importantes implicações setoriais na história, relegando certas atividades - como a produção manufatureira e agrícola - a uma modesta formação de capital, e explicando porque o capitalismo do passado foi essencialmente "mercantil" e "não industrial".

Para além da identificação do capitalismo com o modo de produção industrial, outra ambiguidade recorrente que é apontada pelo autor é a sua confusão com a economia de mercado. Braudel (1996a, p. 193) resgata que a palavra mercado também é muito usada de modo equivocado, por ser comumente aplicada em um sentido bastante amplo a todas as formas de troca - e às vezes até mesmo a um sistema de trocas, a economia de mercado. Para o autor, enquanto o capitalismo é o local da rápida reprodução de capital, a economia de mercado é o sistema de trocas que abrange os mercados de uma determinada zona da vida econômica.

De certo modo, a origem da confusão remete à visão tradicional do mercado autorregulado e promotor do crescimento, que por meio de suas trocas racionais iria englobando e interligando as diferentes regiões, assegurando o equilíbrio das atividades econômicas em torno de uma divisão do trabalho que promoveria o crescimento e prosperidade.Portanto, é uma concepção em que o crescimento econômico corresponde à expansão da economia de mercado (e do capitalismo, tido como sinônimo).

Porém, além de o capitalismo não se restringir a um sistema de trocas, Braudel (1996a, p. 193) critica a tendência a considerar o mercado como um fenômeno dotado da "racionalidade" necessária para promover o equilíbrio e o crescimento econômico independente das forças sociais. Em particular, o autor reprova a consequente distinção entre trocas "sociais" e trocas "legitimamente econômicas", estas últimas identificadas com o "verdadeiro mercado capitalista autorregulado". Em sua visão, o mercado e as suas trocas são, e sempre foram, realidades simultaneamente econômicas e sociais, que além de obedecerem aos imperativos da oferta e da procura,envolvem também diálogos e conflitos entre agentes (governantes, mercadores, bancos, entre outros): "todas as formas são econômicas, todas são sociais. Houve, por séculos a fio, trocas socioeconômicas muito variadas que coexistiram” (BRAUDEL, 1996a, p. 195). 
Em específico, o autor critica a tese desenvolvida por Polanyi (1968) que define a economia como um subconjunto histórico da vida social, formado por mercados e trocas não dependentes de comportamentos "econômicos" - estes só teriam se tornado predominantes com a "explosão do capitalismo no século XIX", quando o mercado “autorregulado"teria subjugado o social até então dominante.No entanto, na realidade, a obra de Polanyi (1968) enseja considerações mais complexas e sofisticadas que vão além desta separação maniqueísta entre "economia" e "sociedade", desenvolvendo uma interessante abordagem sobre a construção da ideologia da "economia de mercado" e o significado da "revolução econômica liberal" do século XIX que enalteceu a busca pelo enriquecimento individual como característica "natural" humana e o mercado como entidade independente da sociedade.

Por meio de uma extensa pesquisa histórica e antropológica, Polanyi (1968, p.43-55) derruba esses pressupostos mostrando que os agentes econômicos nunca foram meros maximizadores de utilidade, e que os mercados sempre exerceram uma função social, fortalecendo os laços entre as pessoas, a cultura e a identidade coletiva.Somente na era moderna,por meio da ação do poder político na Revolução Industrial no fim do século XVII, que teria surgido a ideia de "economia de mercado liberal", uma concepção moderna diversa da predominante nos mercados até então, por anular a sua função social. Impulsionada e apoiada pela força política, a ideologia da "economia de mercado liberal" pretendeu separar a economia da sociedade e subjugá-la, revertendo a ordem das coisas: a sociedade deveria tornar-se acessória da economia, s pessoas e a terra passando a ser elementos constituintes do processo econômico, comprados e vendidos como meras mercadorias. (POLANYI, 1968, p. 68-76)

Entretanto, o autor aponta ter ocorrido uma reação da sociedade a esse movimento:movidos por uma "ética de solidariedade e responsabilidade" em defesa dos valores comunitários e sociais, diversos agentes sociais se uniram em um "contramovimento"chamado pelo autor de a "Grande Transformação"7. Faz parte deste movimento a auto-organização da sociedade em prol de seus interesses, com ou sem a ajuda do governo, consubstanciada nas democracias e na formação da "sociedade civil", um conjunto distinto do Estado de instituições, associações e movimentos que

\footnotetext{
${ }^{7}$ Essa contraposição entre os esforços para estabelecer e difundir o mercado autorregulável, e os esforços para proteger as pessoas e a sociedade, consiste na Teoria do Duplo-Movimento de Polanyi (1968, p. 130134): a tensão e conflito contínuos. Esta seria a raiz da crise da sociedade moderna.
} 
permitiram a participação das pessoas na moldagem do seu mundo social (POLANYI,1968, p. 130-134).

Ou seja, a obra de Polanyi (1968) transcende o debate tradicional entre economia e sociedade, concentrando-se na crítica ao mercado autorregulável, uma ideia moderna que promoveu a dissociação entre economia e sociedade - movimento que foi contraposto, conforme o autor, pela capacidade de reação da sociedade.

Já para Wallerstein (2000, p. 75-76), o capitalismo se identifica com a "economia de mercado" cuja expansão foi apoiada pelo poder político a partir do século XVI, e cuja principal característica é a venda da produção nos mercados mundiais visando a maximizar lucros. Apesar de restringir o capitalismo a um grande sistema de trocas visando ao lucro - tolhendo a flexibilidade destacada por Braudel (1996)- essa visão tem o mérito de destacar a intima interligação do capitalismo com o poder político. Tanto Braudel (1996) quanto Wallerstein (2000) concordam que a expansão e fortalecimento do capitalismo sobre outras regiões e formas econômicas contaram decisivamente com o apoio do poder político, em alianças históricas que permitiram ao capitalismo se expandir mundialmente ao longo do tempo.

De fato, Arrighi (1996, p. 9-13) demonstra que o desenvolvimento do capitalismo enquanto sistema mundial só foi possível com a ascensão do sistema de Estados Nacionais moderno, que institucionalizou a autoridade pública e as leis que distinguem os direitos de propriedade privada e domínio público - uma vez que o sistema medieval de governo era descentralizado e não previa as conotações modernas de posse e soberania. Segundo o autor, a evolução histórica do capitalismo mundial não foi resultado involuntário de atos autônomos na sociedade, mas ocorreu sob a liderança de certos agentes governamentais e empresariais. Em sua visão, os agentes de iniciativa capitalista já existiam "em toda parte, do Egito ao Japão" (p. 11), mas só na Europa depois de 1500 eles começaram a se concentrar por meio de processos históricos que impeliram os nascentes Estados europeus à conquista territorial do mundo, iniciando a formação de um capitalismo mundial ${ }^{8}$. Logo, a transição relevante para compreender a origem do capitalismo mundial não seria a do feudalismo ao capitalismo, mas a dessa iniciativa capitalista dispersa à concentrada, possibilitada pela aliança entre o Estado e o capital.

\footnotetext{
${ }^{8}$ Segundo o autor, na Antiguidade e no fim da Idade Média, as cidades eram as "sementeiras do capitalismo político", mas estas tiveram sua autonomia erodida por estruturas políticas mais amplas: o imperialismo burocrático na Antiguidade; e o sistema de Estados nacionais no fim da Idade Média.
} 
Na realidade, essa aliança servia a interesses de ambos os lados: o Estado proveu a força política necessária à expansão do capitalismo, enquanto este proveu os recursos financeiros necessários à consolidação e fortalecimento dos governos. Destarte, a expansão mundial do capitalismo esteve intimamente vinculada à criação do sistema de Estados Nacionais moderno, ou seja, os dois processos se mostraram interdependentes e interligados. Ora, se a emergência e expansão mundial do capitalismo dependeram da força estatal, o capitalismo constitui-se na antítese da economia de mercado - em contraste à comum identificação entre capitalismo e economia de mercado, com o Estado em oposição a ambos. E foi o Estado que criou e apoiou a expansão desse "contra mercado", tal como o capitalismo é chamado por Braudel (1996), transformando-se no espaço do monopólio e dos privilégios.

Portanto, voltamos à concepção de Braudel (1996) do capitalismo como o "lugar" da mais alta acumulação de capital e do investimento, uma definição que permite caracterizá-lo como um modo de produção ou como um sistema de trocas, a depender do potencial de rentabilidade de cada atividade em cada momento histórico. Simplificadamente, essa natureza flexível e tendente à concentração do poderio político e econômico em torno de alianças entre governo e capital tem importantes implicações, que podem ser consideradas em duas dimensões, uma espacial e outra temporal, a serem elaboradas a seguir.

\subsection{A HIERARQUIA TRIPARTITE DA ECONOMIA-MUNDO CAPITALISTA}

Para Braudel (1996c),compreender as estruturas e lógicas capitalistas envolve situar as realidades econômicas conforme seu espaço e duração. Enquanto a duração refere-se à já justificada escolha pela abordagem de longo prazo, o espaço explica-se por colocar "em causa ao mesmo tempo todas as realidades da história, todas as partes envolvidas da extensão: os Estados, as sociedades, as culturas, as economias" (BRAUDEL, 1996c, p. 12).

De modo análogo, também Wallerstein (2000, p. 71-74) enfatiza a escolha pelas "totalidades" como as unidades de análise adequadas aos interesses da pesquisa social, tanto no seu aspecto temporal quanto espacial.Na realidade, o autor tece uma crítica à 
tendência das ciências sociais a delimitar as partes de um todo em unidades de análise independentes para fundamentar análises comparativas despidas de considerações de tempo e espaço ${ }^{9}$.Para o autor, apesar de nas análises de longos períodos ser necessário dividir o horizonte temporal para observar as mudanças estruturais de um segmento a outro, não se pode jamais perder o "ponto de vista da totalidade", porque as partes não são discretas, mas contínuas, constituindo dimensões de um processo ou lógica maior.Portanto, as partes não fazem sentido se abstraídas de suas irmãs e do seu todo, só sendo compreensíveis se vistas dentro do conjunto do qual fazem parte, devendo ser analisadas como segmentos interligados de uma unidade total.

Analogamente, esse mesmo raciocínio se aplica ao estudo dos integrantes de um sistema internacional, como países ou regiões particulares, cuja estrutura e dinâmica não podem ser adequadamente entendidos se isolados da lógica regional ou internacional em que estão inseridos. Destarte, ao estudar países e regiões, estes devem ser sempre abordados como partes de totalidades ${ }^{10}$, que para Wallerstein $(2000$, p. 74-75) são os "sistemas sociais", tidos por ele como a unidade básica de análise. E o que define um "sistema social", em sua concepção, é a existência de uma divisão de trabalho própria, entendida como a menor "rede" de atividades econômicas que atende às necessidades da maioria dos agentes deste sistema, independente de entidades ou forças externas - um esquema que pode existir sem uma unidade política comum, e até mesmo sem uma cultura comum.

Em sua concepção, o autor identifica terem existido dois tipos de sistemas sociais na História: os minissistemas e os sistemas-mundo. Enquanto os minissistemas foram caracterizados por um sistema cultural único ${ }^{11}$, os sistemas-mundo podiam apresentar múltiplos sistemas culturais, dividindo-se em dois subtipos: os impériosmundo e as economias-mundo, cuja principal diferença é a presença de um sistema

\footnotetext{
${ }^{9}$ Wallerstein (2000, p. 83-85) aponta como exemplo a comum identificação entre industrialização e capitalismo, também abordada por Braudel, e que é refutada quando se considera a industrialização da exUSSR ou o modo de produção europeu predominante entre os séculos XVI e XVIII.Para o autor, talvez parte dessas ambiguidades e deva ao fato do debate intelectual entre liberais e marxistas ter se dado na era da Revolução Industrial.

${ }^{10} \mathrm{O}$ autor aponta ser comum que a falsa identificação das unidades de análise a serem comparadas conduza a falsos conceitos e problemas. Por exemplo, se a unidade de comparação apropriada não forem os países, mas um sistema social mais abrangente, então o problema do "desenvolvimento nacional" perderia o sentido. Cada país não poderia ser considerado uma "unidade de análise" com seu próprio modo de produção e dinâmica de desenvolvimento se constituir parte integrante e dependente de um sistema social, pois partilharia do modo de produção e dinâmica de desenvolvimento dessa "totalidade". (WALLERSTEIN, 2000, p. 73-75).

${ }^{11} \mathrm{O}$ autor demonstra terem sido sociedades muito simples, agrárias ou caçadoras, não mais existentes, tendo sido no geral anexadas a um sistema-mundo e deixado de existir como "sistemas sociais" independentes.
} 
político comum no primeiro, e a sua ausência no segundo. Neste construto teórico, o capitalismo é definido como um sistema social de economia-mundo, não limitado a nações-Estado ou regiões, e desde o século XIX é o único sistema-mundo - os minissistemas não existiriam mais, e os 'impérios-mundo' teriam dominado todas as economias até o período moderno. (WALLERSTEIN, 2000, p. 75-76)

Como para Wallerstein $(2000$, p. 83), a principal característica da "economiamundo capitalista" é uma economia de mercado em expansão movida pelo objetivo de aumentar lucros por meio do comércio internacional, o fim dos impérios-mundo (e das suas enormes burocracias perpetuadoras de gastos improdutivos que enfraqueciam os mercados) teria sido a condição para o seu florescimento hegemônico. Por diversas razões históricas, ecológicas e geográficas, o autor aponta que o Nordeste europeu estava melhor posicionado no século XVI para emergir como o centro irradiador de uma ampliação de mercados, que foi construindo uma vasta estrutura com diversas unidades de produção integradas, apesar de distribuídas por diferentes unidades políticas. Assim,na Europa do século XVI a economia-mundo capitalista emergiu expandindo o comércio progressivamente, incorporando à sua divisão internacional do trabalho novas regiões que foram se especializando e desenvolvendo diferentes "modos de produção" conforme a distribuição local de recursos humanos e naturais. (WALLERSTEIN, 2000, p. 86)

O autor aponta ainda que, enquanto no centro os anseios capitalistas convergiram com os interesses políticos, levando ao estabelecimento de alianças que fortaleceram esses países, na periferia da economia-mundo capitalista esses interesses divergiram, enfraquecendo estas áreas, que às vezes nem chegaram a constituir Estados. Isto teria incentivado "trocas desiguais" entre Estados fortes e regiões fracas - de tal modo que, o capitalismo envolveria não só a apropriação do excedente do trabalho pelo proprietário dos meios de produção, mas também do excedente da economia-mundo inteira pelo seu centro. Formou-se assim uma estrutura de regiões desigualmente poderosas, perpetuada por um processo de concentração de capital no núcleo e de atraso na periferia ${ }^{12}$.

\footnotetext{
${ }^{12}$ No caso da economia-mundo europeia do século XVI, Wallerstein (2000, p. 86-89) levanta duas razões do porque os Estados do centro teriam se fortalecido mais que os da periferia: primeiro, porque na periferia os interesses dos proprietários de terras divergiam dos das burguesias comerciais, enquanto no centro eles convergiam; segundo, porque a força dos Estados do centro era função direta da fraqueza dos da periferia, se reforçando no tempo por meio de guerras, coerção, diplomacia.
} 
$\mathrm{Na}$ realidade, Wallerstein (2000, p. 76-79) parte do conceito cunhado por Frank $^{13}$ de "desenvolvimento do subdesenvolvimento", segundo o qual o estado de subdesenvolvimento de muitos países não constitui uma fase do "processo de desenvolvimento capitalista", nem a forma adquirida por sociedades "tradicionais" ao entrar em contato com sociedades "desenvolvidas", mas sim o resultado desses países ocuparem, nos quatro séculos de existência da economia-mundo capitalista, uma posição periférica de região exportadora de insumos e primários. Nesta visão, ambos o desenvolvimento e o subdesenvolvimento capitalistas seriam fenômenos derivados e perpetuados pelo mesmo processo de expansão da economia-mundo capitalista, em que as regiões atrasadas da periferia teriam seu excedente apropriado pelas regiões desenvolvidas do centro, fortalecendo a estas e se enfraquecendo simultaneamente.

Para Wallerstein (2000), essa desigualdade foi alimentada pelas "forças de mercado", solidificando-se e ficando cada vez mais enraizada: "são as operações das forças do mercado mundial que acentuam as diferenças, as institucionalizam, e as fazem impossíveis de contornar no curto prazo" (p. 89). Neste sentido, o autor reconhece que, apesar de sua tendência enrijecedora, a estrutura da economia-mundo capitalista não é imutável, estando sujeita a processos de rompimento e renovação.A razão de sua relativa estabilidade, pelo menos no médio prazo, em uma dinâmica caracterizada pela distribuição desigual dos rendimentos, estaria na existência de uma "terceira categoria", a semiperiferia, regiões intermediárias razoavelmente desenvolvidas e aspirantes a tornar-se o centro da economia-mundo capitalista.As insurreições generalizadas das áreas periféricas contra a perversidade do sistema foram raras na imensidão da história, apesar do persistente descontentamento, porque a semiperiferia significou "que o estrato superior não enfrenta a oposição unificada de todo o resto, pois o estrato médio é simultaneamente explorado e explorador" (WALLERSTEIN, 2000, p. 80-91).

Destarte, Wallerstein (2000) considera a semiperiferia como uma condição ao equilíbrio e sobrevivência da economia-mundo capitalista ${ }^{14}$, tendo uma essencialidade mais política que econômica, pois uma economia-mundo funcionaria economicamente sem uma semiperiferia, mas não seria politicamente estável porque não evitaria a

\footnotetext{
${ }^{13}$ FRANK, Andre Gunder. The Development of Underdevelopment. New York: Monthly Review Press, 1966.

${ }^{14} \mathrm{Na}$ verdade, Wallerstein (2000) elenca três mecanismos que possibilitaram aos sistemas-mundo manterem uma relativa estabilidade política (na verdade, a sua sobrevivência sistêmica): a concentração do poder militar nas mãos das classes dominantes; a existência de um compromisso ideológico das classes dominantes com o sistema (identificação dos seus próprios interesses com a sobrevivência do sistema); e o mais importante, a divisão da maioria explorada em dois estratos (o baixo e o médio).
} 
polarização extremada. Isso não significa que não houve tensões entre grupos sociais, entre nações e regiões, mas suas consequências devem ser entendidas tendo em vista a lógica da economia-mundo capitalista, em que determinados grupos buscaram a ascensão por meio de distorções do mercado e alianças com o poder político, resultando em alguns mais poderosos do que outros, mas nenhum conseguindo controlar a economia-mundo por completo nem perpetuamente. Especificadamente, Wallerstein (2000, p. 92-94) destaca como mecanismos de defesa e ataque da semiperiferia aspirante a centro:o uso de alianças com o poder político, de estratégias protecionistas e do recurso à guerra (foi o que ocorreu entre o Reino Unido e os Países Baixos entre 1660-1715, a França e o Reino Unido entre 1715-1815, a Alemanha e o Reino Unido no século XIX e a ex-URSS e os Estados Unidos no século XX).

Por meio desses mecanismos a semiperiferia conseguiu por vezes avançar a centro, como os Estados Unidos com o protecionismo e a conjuntura favorável da Segunda Guerra Mundial encontrou meios para ascender à condição hegemônica na economia-mundo capitalista. Destarte, a lógica da economia-mundo capitalista comporta contradições intrínsecas que determinam uma evolução sujeita a crises periódicas e renovações sistêmicas que podem abrir oportunidades de ascensão à sua periferia e semiperiferia, mas sem colocar em risco a estrutura hierárquica.

Já para Braudel (1996c), conforme visto, "capitalismo" e "economia de mercado" são formas econômicas que não se confundem. No entanto, o autor admite a coexistência de ambas as formas ${ }^{15}$, tendo em vista que o capitalismo busca interligar as diferentes regiões e formas econômicas ao seu redor em torno de suas atividades "de eleição", atraindo-as com o seu dinamismo econômico e buscando controlá-las com a força garantida pelas suas alianças com o poder político.

Desse modo, tanto as economias de mercado (vistas como cadeias de mercados interligadas em redes que foram se constituindo ao longo do tempo), quanto uma terceira categoria chamada por Braudel (1996c) de a "não economia" (economias de subsistência), tendem a acabar se voltando para o centro de atração e força capitalista,

\footnotetext{
${ }^{15}$ Braudel (1996c, p. 197) aponta que essa coexistência é abordada,de modos alternativos, por Galbraith em seus estudos sobre a justaposição das pequenas empresas ("sistema de mercado") com as grandes empresas ("sistema industrial"); e por Lênin ao diferenciar o "simples capitalismo" ("concorrencial") do "capitalismo de monopólios" ("imperialismo"). Essas visões tendem a identificar o capitalismo como um "poder acrescido na produção", devido a grande influencia e capacidade de intervenção auferida pelos grandes grupos e organizações capitalistas, inclusive sobre mercados e governos.
} 
sendo aos poucos remodeladas para atender aos seus interesses e integrar a sua dinâmica ${ }^{16}$ :

é como se a centralização e a concentração de recursos... se processassem necessariamente a favor de certos lugares de eleição da acumulação. [...] Essa apropriação é o processo, o "modelo" que preside à construção de qualquer economia-mundo, com os seus monopólios evidentes (p. 26).

Assim, na "economia-mundo capitalista" de Braudel (1996c), a hierarquia de poder econômico tem o capitalismo como o topo que controla as ligações com os demais setores, a economia de mercado como o miolo aspirante a topo ${ }^{17}$, e a "não economia" como a enorme base pobre e "atrasada". Isto é, um "centro restrito, regiões secundárias bem desenvolvidas e a enorme periferia [...] Essa geografia discriminatória ainda hoje logra e explica a história geral do mundo" (BRAUDEL, 1996c, p. 29-74).

Portanto, para Braudel, o modelo de Wallerstein, apesar de ter suscitado muitas criticas, tem muitas aplicações e implicações: é "uma visão sistemática, talvez demasiado sistemática, mas que se revelou fecunda" (1996c, p. 58). No entanto, o autor expressa a ausência de maior tratamento da dimensão temporal nas formulações de Wallerstein, como veremos em seguida, cuja economia-mundo contempla muito bem a divisão do espaço na sua unidade básica de análise, porém não atenta à unidade temporal de referência, pois no espaço europeu sucederam-se várias economiasmundo.Ressaltando a importância de se identificar as regras tendenciais das economiasmundo, o autor considera que a disposição do seu espaço estruturado de forma hierarquizada, regionalizada e especializada é apenas uma delas.

Em especial, Braudel (1996c, p. 24-26) destaca que, se por um lado a existência da semiperiferia sustenta uma situação em que os atritos não se anulam de modo a não ameaçar o poder central que orquestra a dinâmica do conjunto, por outro lado a perene competição do núcleo dominante com outros aspirantes à liderança não permite o equilíbrio perpétuo: os centros não o foram eternamente, tendo sido substituídos ao longo do tempo. No geral, as implicações dessas substituições foram sempre significativas, revelando as fragilidades do equilíbrio anterior e rompendo suas cadeias de dependências, abrindo assim oportunidades para alterações de posições na nova

\footnotetext{
${ }^{16}$ Para Braudel (1996c), o passo essencial foi a anexação desses mercados por um grande mercado urbano ao qual não bastavam os campos próximos, sendo abastecido de longe e dominando longas cadeias econômicas.

${ }^{17}$ Como Wallerstein, Braudel (1996c) também caracteriza as regiões "secundárias" como aspirantes a centro, comumente se valendo do protecionismo como estratégia de ascensão, em uma relação de tensão e complementação com o núcleo dominante, que também delas se aproveita.
} 
hierarquia a ser construída. Apesar de manterem suas características básicas, como o capitalismo como força centralizadora e a hierarquia tripartite, as novas economiasmundo não foram sempre do mesmo tipo, com seus sucessivos centros evoluindo tanto nos seus arsenais de dominação econômica (controle mercantil, bancário, creditício, entre outros) quanto política (cidades-Estado, impérios coloniais, entre outros).

Assim, Braudel (1996c, p. 15) vê a economia-mundo europeia nascer muito cedo, assim como o capitalismo, enquanto que para Wallerstein (2000) ambos só surgem no século XVI. Para Braudel, esse concerto internacional iniciou na Idade Média, desenhando uma hierarquia de produções e trocas em torno de uma ordem econômica europeia, ou ocidental, uma vez que acabou ultrapassando as fronteiras europeias (1996c, p. 45).

Além disso, para Braudel (1996c, p.37-40), as desigualdades entre as diferentes regiões da economia-mundo capitalista não resultam de "vocações naturais" locais que determinam um papel especializado especifico na divisão internacional do trabalho, mas expressam a consolidação de situações lenta e historicamente estabelecidas, em uma cadeia de subordinações e relações de força desiguais ${ }^{18}$. Paralelamente, no interior de cada um dos três estratos da "economia-mundo capitalista",o autor identifica ainda a reprodução dessa estrutura hierárquica tripartite, com o centro sendo pontuado por zonas mais atrasadas, como "manchas" destoantes do dinamismo em torno, e vice-versa, com a semiperiferia e periferia sendo capazes de endogenamente gerar "focos" de dinamismo e riqueza capitalista em seu interior.

Robert Brenner (1977), por outro lado, desenvolve uma crítica a certos aspectos do construto teórico desenvolvido por Walllerstein, realizando uma análise sobre o capitalismo que destaca o papel das estruturas de classe e das relações sociais na determinação da sua dinâmica. Na realidade, sua crítica não se restringiu apenas aos argumentos de Wallerstein, mas aos de toda uma geração de pensadores, geralmente de tradição marxista, cuja produção científica foi em grande parte voltada para compreender a persistência do subdesenvolvimento em certos países, mesmo após a sua integração ao mercado mundial capitalista.

Brenner (1977, p. 25-27) identifica que, no geral, estes autores fundamentaramse no Manifesto Comunista de Marx e Engels (1848), segundo o qual o "processo de

\footnotetext{
${ }^{18}$ É neste sentido que o autor critica a explicação de David Ricardo sobre as trocas entre Inglaterra e Portugal - são desiguais porque Portugal encontrava-se em posição de inferioridade, tendo o tratado de Methuen sido ditado por relações de força, e não de "interesses comuns".
} 
desenvolvimento capitalista" seria mais ou menos inevitável: a ampliação do comércio e do investimento levaria à eliminação dos velhos modos de produção e à sua substituição por relações sociais capitalistas, engatando um processo de acumulação de capital e crescimento econômico. Porém, a análise histórica evidencia uma falha da penetração do comércio e investimentos em amplas partes do mundo em trazer esse desenvolvimento - erigindo, pelo contrário, barreiras sistemáticas ao avanço econômico nessas regiões.

Esse “desenvolvimento do subdesenvolvimento" (Frank, 1966) ${ }^{19}$ levou à revisão do prognóstico "progressista" da teoria marxista por estes pesquisadores que, conforme Brenner (1977, p. 27), acabaram deslocando a transformação das relações de classe do centro das suas análises. Ora, apesar de Marx ter previsto o desenvolvimento capitalista sob a premissa de que a expansão do comércio e investimento inevitavelmente levaria à transformação das relações de classe pré-capitalistas em capitalistas, o autor pondera que essa expansão pode não ter destruído os velhos modos de produção, ou criado outros modos não capitalistas - resultados possíveis, tendo em vista que a origem e evolução das estruturas de classe não são compreensíveis apenas em termos de "forças de mercado".

Destarte, Brenner (1977, p. 26-27) ressalta que a mera ampliação do comércio e investimento não implica necessariamente no surgimento automático de relações de classe capitalistas $^{20}$. Para o autor, esta linha de pesquisadores não apenas não prevê esta possibilidade, geralmente deixando de lado o papel central das estruturas sociais para a compreensão do subdesenvolvimento. Em vez disso, eles buscam negar o resultado de equilíbrio e prosperidade econômica previstos pelo modelo de desenvolvimento de Adam Smith, em que a expansão do comércio levaria à divisão internacional do trabalho e ao desenvolvimento econômico generalizado ${ }^{21}$, construindo argumentações para sustentar que esses mesmos processos capitalistas pressupunham, ao contrário, o reforço do atraso econômico.

O caso de Wallerstein é emblemático para Brenner (1977, p.53-55), por não abordar os limites e potencialidades dados pela estrutura de classes de cada região. Como para Wallerstein é a "produção por lucro no mercado" que determina o

${ }^{19} \mathrm{Ibid}$.

${ }^{20}$ Brenner (1977, p. 26) aponta que Marx depois visualizou a possibilidade da solidez de certos modos pré-capitalistas representar barreiras impeditivas à adoção de modos de produção capitalistas, como os modos de produção pré-capitalistas da Índia e China frente à expansão comercial inglesa.

${ }^{21}$ Cabe ressaltar que se trata de uma interpretação que Brenner (1977) supõe que esses pesquisadores tenham feito sobre a obra de Adam Smith, que é muito mais complexa do que isso. 
desenvolvimento capitalista, o problema da sua origem é erroneamente por ele identificado com o da origem da expansão irrestrita do mercado mundial, e o desenvolvimento do capitalismo vira o desenvolvimento da divisão internacional do trabalho promovida pela expansão do comércio. Assim,qualquer região incorporada à "economia-mundo capitalista" no século XVI se tornaria capitalista, qualquer que fosse sua estrutura social-produtiva, de tal modo que as regiões servis cessariam de ser menos capitalistas que as regiões de trabalho livre assalariado ${ }^{22}$.

Além disso, Brenner (1977, p.59-63) aponta que a tese de Wallerstein permite chegar à conclusão que o desenvolvimento e subdesenvolvimento capitalista são derivados do mesmo processo, sendo direta e mutuamente determinados por serem ambos resultantes de uma transferência de excedentes da periferia ao centro. Porém, o autor defende que nenhum dos dois pode ser diretamente dependente e causado pelo outro, pois cada um resulta de uma evolução específica de relações de classe. Ademais, a especialização das diferentes regiões interligadas pelo comércio não se dá conforme suas "vantagens naturais", levando a uma hierarquia produtiva em que certas atividades requerem mais habilidade técnica e capital do que outras, desenvolvendo mais alguns locais do que outros. Para o autor, é o nível de desenvolvimento das forças produtivas da região que determina as atividades produtivas a serem desenvolvidas na região, e não o inverso.

Portanto, na concepção de Brenner (1977, p. 90-92) não é possível aceitar que o subdesenvolvimento capitalista em certas regiões resultou simplesmente da sua incorporação ao mercado mundial. Em sua visão, nem o desenvolvimento no centro nem o subdesenvolvimento na periferia foram determinados pela transferência de excedente, ainda que esta seja importante e tenha ocorrido. Esses são aspectos do subdesenvolvimento, mas precisam ser explicados, especialmente com base nas estruturas de classe da periferia.

Para Brenner (1977, p. 82-92), o desenvolvimento foi um processo qualitativo que envolveu a contínua acumulação de riqueza, revolução das técnicas e aumento da produtividade, graças a uma estrutura de classes em que os grupos capitalistas eram obrigados a usar métodos produtivos que correspondiam às necessidades de desenvolvimento das forças produtivas e de incremento do excedente relativo. Em contrapartida, o subdesenvolvimento baseou-se em uma estrutura de classes

\footnotetext{
${ }^{22} \mathrm{O}$ argumento de Wallerstein é que os modos de produção são escolhidos pela classe dominante frente aos incentivos do mercado e dadas as características e condições locais de sua região.
} 
fundamentada na extração do excedente absoluto do trabalho, determinando uma disjunção entre os requisitos para o desenvolvimento das forças produtivas e os objetivos de extração de excedentes, desencorajando o uso do capital fixo e o desenvolvimento de habilidades. Portanto, as origens do desenvolvimento capitalista estão nos processos históricos pelos quais as estruturas de classe pré-capitalistas foram dissolvidas e redefinidas em estruturas capitalistas, que são compreensíveis apenas como processos conflitantes de transformação e luta de classes.

O que tudo isso implica para economias subdesenvolvidas como a brasileira? Ao ressaltar o aspecto qualitativo do processo de acumulação de capital característico das economias centrais, marcadas pela revolução técnica e melhora produtiva, e apontar o papel das estruturas socioeconômicas locais pré-existentes na viabilização desse fenômeno, Brenner (1977) evidencia a importância da análise das diversas formas socioprodutivas que compõem a estrutura da economia brasileira como requisito para completar a compreensão de seus horizontes de desenvolvimento. A apreensão dessas estruturas domésticas e da sua lógica de funcionamento são essenciais para entender os rumos tomados pelo país diante das condicionalidades sistêmicas derivadas da dinâmica da economia-mundo capitalista.

\subsection{OS CICLOS SISTÊMICOS DE ACUMULAÇÃO E A GEOPOLÍTICA DO CAPITALISMO}

Se de um lado a economia-mundo capitalista de Wallerstein dá conta de explicar a dimensão espacial e hierarquia regional que decorrem do capitalismo, por outro lado a dimensão temporal, como pontuou Braudel (1996), também tem importantes implicações que merecem um maior desenvolvimento e análises adicionais. Em especial para as economias periféricas, a compreensão das lógicas que modelam a evolução histórica das estruturas mundiais são de grande relevância para a identificação de oportunidades, a resolução dos problemas e a construção de estratégias que garantam sua ascensão na hierarquia econômica mundial.

Como Braudel, Arrighi (1996, p. ix-xii) também insiste na definição da longue durée como o horizonte temporal adequado para empreender o estudo da origem e expansão do capitalismo como sistema mundial, tendo em vista que suas tendências e 
conjunturas no século $\mathrm{XX}$ - os motivos originais de sua análise - talvez refletissem estruturas e processos em curso desde o século $\mathrm{XVI}^{23}$. Desse modo, ele direciona a sua pesquisa para identificar os padrões evolutivos que acredita terem permeado o desenvolvimento histórico do capitalismo mundial, e as condições sistêmicas em que esses processos se desenvolveram no tempo.

Retomando a caracterização braudeliana do capitalismo como essencialmente "flexível" e "eclético", deslocando-se pelas atividades econômicas conforme as oportunidades de lucro, Arrighi (1996, p. 3-6) enfatiza que o caráter cíclico do capitalismo remonta à sua relação meramente instrumental com os modos de troca e produção. Quando essa relação não mais atende ao objetivo de acumulação, o capitalismo tende a retornar às suas formas mais liquidas (o capital financeiro) até identificar uma nova atividade com potencial atraente de acumulação. Portanto, as “expansões financeiras" 24 sinalizariam a maturidade de um ciclo de expansão capitalista que permitiu uma forte acumulação de capitais, mas que se exauriu: "[Todo] desenvolvimento capitalista desse tipo, ao atingir o estágio de expansão financeira, parece anunciar em certo sentido, a sua maturidade" (Braudel, 1984 ${ }^{25}$, apud Arrighi, 1996, p. 6).

Para o autor, este raciocínio também pode ser expresso pela clássica fórmula de Marx, DMD', segundo a qual na lógica capitalista o “capital-dinheiro” D (liquidez) pode ser investido em qualquer atividade produtiva $M$ (rigidez), mas sempre visando à ampliação do capital-dinheiro inicial D' (liquidez acrescida), e não à produção propriamente dita. Isto significa que a produção é apenas um meio em que a liquidez é empregada para auferir mais liquidez, de modo que quando este meio produtivo se esgotasse, poderia haver um retorno à liquidez até que outro meio mais rentável fosse encontrado. Em conclusão, Arrighi (1996, p. 6) aponta que um padrão histórico do capitalismo mundial pode ser identificado, em que épocas de expansão produtiva - ou “mudanças contínuas" (DMD') - se alternaram com épocas de crise, de relações

\footnotetext{
${ }^{23}$ Apesar de concordar que o capitalismo remonta desde tempos muito antigos, para o autor o início da sua "mundialização" deu-se no fim da Idade Média, quando diversos processos históricos impeliram as nações europeias à conquista territorial do mundo, iniciando assim a formação da economia-mundo capitalista.

${ }^{24} \mathrm{Na}$ crise dos anos 1970, um de seus aspectos principais foi a "financeirização" do capital, amplamente anunciado como o último e mais avançado estágio do capitalismo mundial. Porém, a expansão do capital financeiro não é uma etapa do capitalismo mundial, nem o seu estágio mais avançado, sendo recorrente ao capitalismo como sinal da destruição de "antigos" regimes de acumulação e a transição a "novos" regimes.

${ }^{25}$ BRAUDEL, F. La Dynamique du Capitalisme.Paris: Éd. Arthaud, 1985.
} 
puramente financeiras e de reestruturação - ou "mudanças descontínuas" (DD’). E de fato, o autor mostra que a evolução histórica do capitalismo mundial sempre alternou momentos de expansão produtiva com períodos de crise e reestruturação, em que os segundos sempre foram mais longos que os primeiros, e resultaram em reorganizações do capitalismo sobre bases novas e mais amplas.

Fundamentando-se nessa concepção das expansões financeiras como fases finais dos "grandes desenvolvimentos capitalistas", Arrighi (1996, p. 6-26) decompõe a história do capitalismo mundial em quatro unidades de análise chamadas "ciclos sistêmicos de acumulação". Seguindo a preocupação de Wallerstein com "as totalidades históricas" como unidades de análise adequadas, o autor não concebe esses ciclos como partes subordinadas de um todo pré-concebido ou como casos independentes, mas como partes interligadas de um único processo histórico de expansão mundial do capitalismo. Sequencialmente, eles se sobrepõem, e apesar de durarem cada vez menos, todos duram mais de um século (os "longos séculos") 26 .

Visando a identificar os padrões evolutivos do capitalismo enquanto sistema mundial, os seus "desvios" e as condições sistêmicas que determinam a continuidade ou rompimento das tendências anteriores, o autor se propôs a fazer uma análise comparativa desses quatro ciclos. Ele enfatiza que essa análise deve ser realizada por "comparação incorporada", sem presumir os ciclos, mas os construindo factual e teoricamente. E é deste modo que ele confirma a continuidade com rupturas, que alterna ciclos de "fases de mudanças contínuas e fases de mudanças descontínuas" (Arrighi, 1996, p. 9), como padrão histórico do capitalismo mundial.

Tendo em vista a estrutura tripartite braudeliana da economia-mundo capitalista, ao confrontá-la com o seu caráter cíclico, Arrighi conclui que, se no curto prazo a estabilidade do sistema é garantida pela coexistência tensa entre as três posições estruturais, no longo prazo ela "é baseada na mudança perene das suas partes" (1990, p. 15). Assim, a estrutura da economia-mundo capitalista e as relações entre suas partes alteram-se continuamente no tempo e no espaço, movidas por inovações políticas, econômicas e tecnológicas. O autor argumenta ainda que as alterações nas relações do

\footnotetext{
${ }^{26}$ Esses ciclos diferem dos "ciclos seculares" e dos "ciclos de Kondratieff" citados por Braudel, qualificados por Arrighi (1996, p. 6-9)como construções empíricas de base teórica incerta:por se nortearem pela evolução de longo prazo dos preços, não são indicadores adequados dos ciclos do capitalismo mundial, pois a renda do capital pode se reduzir ou aumentar tanto em fases de contração quanto de expansão de preços, a depender da concorrência e da demanda. Além disso, as expansões financeiras podem ocorrer em seu início, meio ou fim.
} 
tipo "centro-periferia" não resultam tanto de combinações particulares de atividades econômicas, mas principalmente de um processo sistêmico de luta perene por maiores rendas na divisão internacional do trabalho ${ }^{27}$.

Lembrando que o processo de expansão do capitalismo foi apoiado e apoiou os interesses do poder político ${ }^{28}$, de tal forma que graças às alianças com os Estados nacionais o capitalismo foi progressivamente se afirmando como a camada superior da economia-mundo, Arrighi (1996, p. 11-13) destaca que essas alianças também não foram estáveis ou eternas. Os recursos capitalistas eram intensamente disputados pelos Estados, em uma grande competição interestatal pelo capital circulante que foi crucial para criar oportunidades ao capitalismo e fortalecer as organizações governamentais e empresariais que lideraram os regimes de acumulação capitalista. Essa competição interestatal garantiu a expansão e continuidade da economia-mundo capitalista ao impelir a concentração de poder político e econômico em determinadas nações, tendo em vista que as grandes expansões materiais exigem a existência de capacidade suficiente de uma nação para contornar ou controlar a competição interestatal, de modo a auferir um mínimo de cooperação entre os Estados.

Portanto, segundo Arrighi (1996), as duas condições fundamentais às expansões do capitalismo mundial foram a competição interestatal pelo capital circulante e a formação de estruturas políticas com capacidade crescente para promover e controlar a acumulação de capital $^{29}$ :

O que impulsionou a prodigiosa expansão da economia mundial capitalista nos últimos 500 anos, em outras palavras, não foi a

\footnotetext{
${ }^{27}$ Arrighi (1990, p. 11-14) questiona a separação dos países em "núcleo", "semiperiferia" e "periferia" com base no seu grau de industrialização e papel em uma divisão internacional do trabalho, perpetuado por "trocas desiguais". Em sua visão, essa classificação não se sustenta diante da industrialização avançada de muitos países da semiperiferia, que se inserem na divisão internacional do trabalho como exportadores de manufaturados. Para ele, existem tendências explorativas e excludentes do sistema (os "processos de exploração e de exclusão") que reforçam a acumulação de riqueza pelo núcleo e perpetuam a pobreza nas áreas periféricas.

${ }_{28}$ Assim o autor justifica focar sua pesquisa na relação entre o dinheiro e o poder, apesar do custo de não abordar a luta de classes e a polarização do mundo em centros e periferias. Ele admite que o foco nessa camada superior é o principal limite de sua análise, rendendo seu estudo parcial e inconclusivo, pois a lógica da camada superior só pode ser entendida em relação às lógicas das outras camadas. Porém diante da dificuldade de se analisar as três simultaneamente, o autor acredita que ao focar no "verdadeiro lar do capitalismo... desvendaremos o segredo da obtenção dos grandes e sistemáticos lucros que permitiram ao capitalismo prosperar e se expandir" (1996, p. 25).

${ }^{29}$ Arrighi (1996) ressalta que na realidade o vínculo histórico entre capitalismo e sistema moderno estatal foi marcado tanto pela unidade quanto pela contradição, em uma relação que foi colaborativa e também conflitante. Isso porque a competição interestatal pelo capital criou oportunidades de expansão ao capitalismo, mas às vezes também onerou o capitalismo ao degenerarem combates bélicos, destruindo os lucros ao desviar recursos à guerra. Similarmente, apesar da tendência de grupos capitalistas específicos a mobilizar os governos em prol de seus interesses ter contribuído para fortalecer a segmentação política, esta nem sempre é a regra, como no caso das estruturas produtivas transnacionais.
} 
concorrência entre Estados como tal, mas essa concorrência aliada a uma concentração cada vez maior do poder capitalista no sistema mundial como um todo. (ARRIGHI, 1996, p. 13)

Destarte, apesar de se referirem ao sistema como um todo, cada ciclo definido por Arrighi (1996) é identificado à unidade política central do seu processo de acumulação de capital em escala mundial: o genovês (séculos XV-XVI); o holandês (séculos XVIXVIII); o britânico (séculos XVIII-XX) e o norte-americano (séculos XIX em diante). Todos os quatro ciclos tiveram seus Estados capitalistas dominantes e grupos líderes empresariais, tendo similarmente intercalado fases de expansão material com fases de expansão financeira e reestruturação. Sequencialmente, cada Estado abarcou dimensões, recursos, poderio e alcance maior que o seu predecessor, cada um constituindo uma etapa do desenvolvimento do sistema capitalista mundial. E cada novo centro, nota Arrighi (1996), foi capaz de promover verdadeiras "revoluções organizacionais" em suas estratégias e estruturas para iniciar um novo ciclo de acumulação, levando-o a ponderar que "em geral, a conquista dessas aptidões organizacionais resultou muito mais de vantagens de posicionamento, na configuração espacial cambiante da economia capitalista mundial, do que da inovação em si.” (p. 14).

No que diz respeito à capacidade das zonas periféricas de romper suas relações de dependência e ascender ao centro da economia-mundo capitalista, o autor mostra que as estruturas de dependência se fazem ainda mais rígidas por meio da sua reprodução interna no âmago dos arcabouços socioprodutivos da própria periferia, havendo a necessidade de que grupos políticos nacionais suficientemente poderosos entrem decisivamente na competição interestatal pelo capital circulante e tenham a capacidade e o interesse de formar, junto aos grupos empresariais domésticos, organizações com poder político e econômico superior aos dos centros de dinamismo estrangeiros para promover e controlar a sua própria acumulação de capital em escala mundial.

Em um âmbito mais geral, as consequências geopolíticas dessa dinâmica instável da economia-mundo capitalista e sua sucessão de "centros hegemônicos" são trabalhadas de forma bastante interessante pelo geógrafo David Harvey (2005), que propôs a criação de uma "teoria da geografia histórica do capitalismo"

Nossa tarefa é elaborar uma teoria geral das relações espaciais e do desenvolvimento geográfico sobre o capitalismo, que possa [...]

\footnotetext{
${ }^{30}$ Segundo o autor, a Geografia foi "desprezada" em "toda a teoria social", que tendeu a priorizar a História por considerar o espaço como um contexto dado e estável, não problemático. Assim, as estruturas e relações espaciais sempre foram, no geral, ajustadas $a d$ hoc às análises, como redefinições externamente impostas.
} 
explicar a importância e evolução das funções do Estado (locais, regionais, nacionais e supranacionais), do desenvolvimento geográfico desigual, das desigualdades inter-regionais, do imperialismo, do progresso e das formas de urbanização. (p. 144)

Harvey (2005) destaca as implicações do espaço e da geografia na determinação da estrutura e dinâmica capitalista, e vice-versa, ou seja, as implicações desta sobre as paisagens geográficas. Em sua interpretação, o capitalismo é um "sistema de circulação de capital que tem o lucro como objetivo direto" (HARVEY, 2005, p. 129), envolvendo em seu funcionamento infraestruturas físicas e sociais (os "espaços de produção e consumo"). No desenrolar de sua dinâmica instável, essas infraestruturas são construídas, modificadas e destruídas, com profundas implicações sociais e geopolíticas.

Em particular, o autor destaca a permanente busca pelo incremento da acumulação de capital, que exige um correspondente aumento da produtividade do trabalho e dinamismo tecnológico e organizacional. Em sua visão, disso surge a principal contradição do capitalismo, geradora de instabilidade e crises: a realização desse dinamismo tecnológico e organizacional implica na substituição do trabalho e do capital "obsoleto", que não conseguem ser aproveitados e ficam inativos, gerando capacidade ociosa e desemprego, em um "estado de superacumulação" que tende à desvalorização e destruição dessa infraestrutura física e social, propiciando tensões e conflitos. (HARVEY, 2005, p. 134-136)

Provisoriamente, esses problemas podem ser contornados por meio do que Harvey chama de "deslocamentos espacial e temporal", reorganizações geográficas e tecnológicas que permitem a absorção temporária desses excedentes (2005, p. 136). O deslocamento temporal pode se dar, por exemplo, por meio de investimentos de longo prazo (como infraestruturas físicas e sociais) ou do uso de "capital fictício" (ações, debêntures e outros instrumentos financeiros de contratação de obrigações futuras), mecanismos que permitem absorver os excedentes disponíveis de forma a adiar a crise no tempo. Porém o risco de não maturação desses investimentos de longo prazo ou de inadimplência permanece, de modo que Harvey (2005) conclui que a crise pode ser adiada por meio de deslocamentos temporais, mas não se torna inevitável.

Já o deslocamento espacial diz respeito à expansão ou reestruturação dos espaços geográficos, podendo ocorrer por meio da exportação ou importação de excedentes (como a colonização de novos territórios), da eliminação de "barreiras e limites espaciais" ou da transformação das relações geográficas. Harvey (2005, p. 153-157) 
nota que, no geral, o espaço surge como obstáculo ao capitalismo, ao dificultar a realização do lucro no menor tempo possível e impor um esforço permanente de "anulação do espaço pelo tempo". O aparente contracenso é que isso só pode ser alcançado por elementos espaciais fixos (como redes de transporte e comunicações) de tal modo que a organização espacial é necessária para superar o próprio espaço.

Em outras palavras, Harvey (2005, p. 144-149) aponta que a circulação do capital constrói "coerências estruturadas" de produção e consumo em um determinado espaço, moldando uma "geografia da produção". Quando representada por um Estado, esta coerência se torna bem perceptível em seu território, evidenciada pela sua infraestrutura física, sistema social, organização trabalhista, regulamentações, cultura, etc. No entanto, apesar de fundamentadas em estruturas fixas, elas são sujeitas às mesmas contradições do capitalismo, sofrendo modificações e reestruturações recorrentes ${ }^{31}$. Pode-se dizer que o desenvolvimento capitalista busca criar e moldar a paisagem física e social às suas necessidades em um instante, para destruí-la no posterior quando não mais the serve, de forma a sempre reformular as estruturas geográficas.

Segundo Harvey (2005, p. 150-153), o surgimento de "alianças regionais de classes" é uma resposta à necessidade da sociedade de defender as comunidades e valores de uma coerência estruturada já estabelecida em um espaço. Essas alianças diferem conforme os grupos de interesses envolvidos, as condições locais e seus objetivos, podendo ter relações diversas com o Estado e suas instituições - de tal modo que os processos de lutas de classes ganham um novo significado, e as crises capitalistas podem se degenerar em conflitos bélicos e territoriais.

Neste contexto de alianças regionais concorrentes, as tentativas de contornar temporariamente as crises por meio de deslocamentos temporais e espaciais podem ter importantes implicações geopolíticas. Um exemplo apontado pelo autor é o caso dos “ajustes espaciais", que implicam em mudanças na configuração dos territórios soberanos - como a exportação de ambos os excedentes de capital e trabalho para construir uma nova capacidade produtiva em outras áreas (as colônias), permitindo uma expressiva e duradoura absorção dos excedentes ociosos. O problema é que, segundo Harvey (2005, p. 153-157), eventualmente a "nova" economia tenderá a alcançar a sua própria coerência estrutural e aliança de classes regional, sendo vítima das contradições

${ }^{31}$ Por exemplo, a superacumulação de excedentes e a luta de classes podem pressionar o deslocamento do capital e/ou trabalho; a dinâmica tecnológica e organizacional pode alterar os limites territoriais, tornando-os instáveis e porosos; e as novas formas capitalistas de organização (como as multinacionais) podem aumentar a liberdade de ação dos agentes privados e abalar os espaços soberanos nacionais. 
da sua própria circulação de capital. Isto é, ela se tornará instável e obrigada a fazer os seus próprios deslocamentos temporais e espaciais, sendo possível até que essa nova economia entre em competição com a nação "mãe" e force a desvalorização nela (como foi o caso dos EUA em relação ao Reino Unido) ${ }^{32}$.

Novamente, a desvalorização é inevitável - a não ser que novas regiões sejam abertas. Portanto, o autor conclui que as contradições do capitalismo permanecem, e em algum momento irromperão em crise: "A consequência... é difundir as contradições do capitalismo em esferas sempre maiores" (HARVEY, 2005, p. 156). As crises podem ser adiadas, mas não podem ser evitadas e ameaçam converter o processo de crise convencional - em que a superacumulação e desvalorização de excedentes leva à destruição da infraestrutura física e social ociosa e ao surgimento de tensões sociais domésticas -, em um processo de crise internacional e conflitos geopolíticos - pautado por embates econômicos, políticos e militares entre nações:

Em virtude do inexorável processo de formação da crise, a busca pelo ajuste espacial converte a ameaça da desvalorização em uma luta entre alianças regionais instáveis [...] liberando suas tendências destrutivas para o exterior. A exportação do desemprego, inflação e capacidade produtiva ociosa se tornam as apostas de um jogo arriscado. As guerras comerciais, o dumping, as tarifas... a conquista colonial, a subjugação e o controle das economias dependentes... e, finalmente, a destruição física e a desvalorização forçada resultantes da confrontação militar e da guerra podem ser consideradas como parte e parcela dos processos de formação e solução da crise. (HARVEY, 2005, p. 156-157).

Em síntese, essa visão permite explicar o jogo geopolítico e suas sérias implicações que permearam a história da economia-mundo capitalista, cujos sucessivos centros de dinamismo promoveram, cada um a seu modo, seus próprios deslocamentos temporais e espaciais na tentativa de adiar o fim de seus ciclos sistêmicos de acumulação, gerando importantes transformações na estrutura do sistema.

\footnotetext{
32 Segundo o autor, uma forma de evitar tal situação, que foi bastante comum na história, seria forçar um desenvolvimento dependente na nova região, porém, o seu dinamismo econômico seria insuficiente para absorver os excedentes da nação "mãe".
} 


\subsection{SÍNTESE: LAPIDANDO AS CATEGORIAS}

Boa parte das dificuldades para compreender o capitalismo enquanto sistema mundial e suas múltiplas implicações para as diversas partes que o integram reside na inadequação das ferramentas conceituais utilizadas para avaliar essa complexa realidade. Destarte, buscou-se apoio nos estudos de alguns importantes pensadores sobre o assunto, que apesar de assumirem posturas ora discordantes, ora complementares, em seu conjunto de ideias revelam uma grande riqueza elucida Dora.

Não se pretendeu aqui realizar uma síntese completa de todos os autores citados, um empreendimento assaz complexo e que foge ao escopo desta pesquisa. O objetivo é apenas realizar uma apropriação instrumental das categorias abordadas, de modo que dialoguem entre si e sejam úteis para a análise do contexto objetivado. Neste sentido, é crucial manter em mente que os textos desses escritores possuem local e data de concepção, além de espelharem em alguma medida suas filiações ideológicas. Também se deve ressaltar que a contraposição de suas visões não consegue prescindir de um esforço de descategorização e revisão de pressupostos, para assim permitir a identificação dos instrumentos teóricos mais adequados à proposta dos capítulos subsequentes.

De certa forma, cada um desses intelectuais já realiza em suas análises um esforço de reler, resignificar e dar novas aplicações aos conceitos e ideias desenvolvidas por seus interlocutores: é inegável o diálogo entre Braudel, Wallerstein e Polanyi; a interlocução de Arrighi com os três acima mencionados, e que se completa com o olhar espacial de Harvey; a crítica de Brenner à Wallerstein; e a releitura que todos eles fazem de Marx. Logo de início, fica claro que o objeto central a todos eles - capitalismo - é carregado de diferentes interpretações, teorias e ideologias políticas e socioeconômicas, a depender das hipóteses, contextos históricos e lugares de referência.

Tendo em vista o objetivo de compreender como a lógica e estruturas capitalistas podem afetar a posição e o destino de economias periféricas, como a brasileira, a visão mais ampla do capitalismo de Braudel (o "lugar do investimento e da alta taxa de reprodução de capital") permite abordar o capitalismo como uma categoria históricoespacial de alto poder explicativo. Tanto a sua "dimensão espacial" veiculada pela "economia-mundo capitalista" de Wallerstein, quanto a sua "dimensão temporal" descrita pelos ciclos sistêmicos de acumulação de Arrighi, subsidiam de modo 
fundamental a análise da inserção internacional da economia brasileira, a sua história e potencial para o ganho de maior autonomia.

Espacialmente, a formulação da "economia-mundo capitalista" ("zona de coesão economicamente autônoma" na terminologia de Braudel ou "sistema social com divisão de trabalho própria" na conceituação de Wallerstein)permite visualizar as diferentes posições estruturais que cada região ocupa na hierarquia internacional do capitalismo. Além disso, a formação de uma divisão internacional do trabalho apontada por Wallerstein fornece uma explicação para as condições de desenvolvimento e subdesenvolvimento de suas diferentes regiões, relacionando-as à especialização produtiva de cada região incorporada à economia-mundo capitalista em expansão conforme suas condições locais (recursos naturais e humanos).

Nesta visão, o estado de subdesenvolvimento brasileiro não seria uma fase em um "processo de desenvolvimento capitalista", nem a forma adquirida por uma sociedade "arcaica" ao entrar em contato com o mundo "avançado", mas sim o resultado de ter sido incorporado à economia-mundo capitalista na sua periferia, estabelecendo relações comerciais caracterizadas como "trocas desiguais" e durante séculos tendo sua situação de pobreza perpetuada pela transferência de seu excedente ao centro.Devido às "forças de mercado", essa desigualdade se enraizaria de tal modo que a sua superação se mostraria estruturalmente complexa, exigindo um processo de longo prazo que envolveria a própria reconfiguração das estruturas do capitalismo mundial.

No entanto, conforme alerta Brenner (1977), o subdesenvolvimento não pode ser reduzido a simples resultado da incorporação das terras brasileiras ao comércio internacional. É preciso considerar o papel das instituições e estruturas socioprodutivas já existentes no local, sendo do encontro dessas estruturas domésticas com as sistêmicas que a inserção do país na economia-mundo capitalista seria determinada, em um processo complexo de ligações dinâmicas entre diferentes formas socioeconômicas nativas e estrangeiras. Assim, a estrutura socioeconômica colonial teria permitido apenas a sua incorporação à economia-mundo europeia como região fornecedora de insumos, tendo seu excedente apropriado pela metrópole lusitana, e estabelecendo desde o início relações de dependência do tipo centro-periferia, as quais se mostrariam cada vez mais dinâmicas e complexas.

Apesar de estas ligações terem se redefinido ao longo do tempo, destruindo e compondo novos formatos de relação, desde então sempre foi mantido o vínculo de dependência como linha dorsal da inserção internacional do país. Não apenas, cabe 
ressaltar, devido ao histórico de relações com a economia-mundo capitalista, mas também como resultado das dificuldades de superação da própria estrutura socioprodutiva doméstica.Ou seja, o caminho para o desenvolvimento brasileiro requer não só vencer a rigidez hierárquica da economia-mundo capitalista como também a de suas próprias estruturas e instituições socioeconômicas.

No que diz respeito às possibilidades de ascensão e ganho de autonomia das zonas periféricas, o padrão cíclico do capitalismo mundial identificado por Arrighi significa que, historicamente, oportunidades foram abertas para a ascensão e conquista de posições por alguns países e regiões da periferia e semiperiferia. No "roteiro" de ascensão, expansão e declínio dos sucessivos centros da economia-mundo capitalista, alternando períodos de concentração de capital em uma determinada atividade produtiva (ou mercantil) com períodos de retorno do capital à sua forma financeira, transformações importantes foram possibilitadas na estrutura do sistema, com alterações significativas na hierarquia de poder internacional.

Como veremos a partir dos autores brasileiros, ao longo das transições de um ciclo sistêmico a outro, de um centro capitalista a outro, e de um regime de acumulação de capital a outro, a economia brasileira foi ganhando em complexidade e desenvolvendo sua estrutura socioprodutiva, porém sem nunca superar seu estado de dependência, no máximo redefinindo-o sobre novas condições. Apesar dos inegáveis avanços em direção a uma economia mais diversificada, não logramos assumir o controle completo de nossa própria acumulação de capital, e não deixamos de ser economicamente dependentes.

Cabe ressaltar ainda o papel central do Estado para o processo de acumulação capitalista. Tanto Wallerstein quanto Braudel,Arrighi e Harvey concordam que a ascensão do sistema moderno de Estados soberanos foi crucial para a expansão e continuidade da "economia-mundo capitalista", com o capitalismo tendo se apoiado no poder político para se afirmar como o topo da economia-mundo, restringir os mercados e alimentar-se de monopólios. E mais, para esses autores, o uso de barreiras econômicas foi um recurso comum a todos os Estados semiperiféricos que conseguiram alçar-se a centro da economia-mundo capitalista, e que a aliança do capital com os governos foi essencial para essa ascensão. 


\section{CAPÍTULO 2}

\section{AUTONOMIA E DEPENDÊNCIA INTERNACIONALDA ECONOMIA BRASILEIRA: ENFOQUE HISTÓRICO E SISTÊMICO}

\subsection{INTRODUÇÃO}

Uma vez delineadas as fronteiras conceituais que conformam nossa visão da dinâmica do capitalismo como sistema político-econômico mundial, ou melhor, da economia-mundo capitalista, passa-se então à análise de algumas interpretações sobre a inserção internacional do Brasil e de como essa inserção foi afetada em alguns momentos cruciais de reestruturação econômica mundial, objetivo central do nosso trabalho. Cabe, inicialmente, ressaltar que as visões apresentadas no capítulo anterior compõem apenas uma amostra, embora importante, do universo de teorias e escolas de pensamento sobre o capitalismo. Sua seleção justifica-se, tendo em vista as hipóteses desta dissertação, pelas suas possibilidades interpretativas do capitalismo enquanto sistema político-econômico e categoria histórico-geográfica do qual o Brasil é parte integrante desde a sua incorporação como colônia, permitindo esclarecer o funcionamento e processos fundamentais que norteiam o panorama econômico mundial no qual evoluiu a economia de nosso país desde então.

O objetivo deste capítulo é analisar como alguns importantes pensadores brasileiros se debruçaram sobre a questão da relação entre a economia nacional e a economia-mundo capitalista ${ }^{33}$. São eles Caio Prado Júnior, Celso Furtado e Ignácio Rangel. Em comum, além de sua proeminência intelectual, todos eles analisaram e pensaram a economia brasileira a partir não apenas de suas estruturas internas, mas também de seus determinantes externos, o que nos permite aventara difícil ponte interrelacional entre a nossa história econômica e a da economia-mundo capitalista. Apesar de não terem usado esse conceito (e nem o poderiam), e a despeito de suas diferenças metodológicas e ideológicas, esses intelectuais dedicaram-se a entender os diversos

\footnotetext{
${ }^{33} \mathrm{Na}$ realidade, nenhum desses autores utilizou em suas formulações o arcabouço teórico referente ao conceito de economia-mundo capitalista. Ao trazer esses conceitos e categorias não abordados por eles, visamos aproximar universos conceituais aventados como complementares, em uma tentativa de estabelecer uma ponte entre essas duas composições explicativas e compor um quadro mais compreensivo do objeto da pesquisa.
} 
aspectos da economia brasileira à luz de sua complexa interação com a economia mundial, permitindo, cada qual à sua maneira, identificar como o país foi aos poucos logrando redefinir sua condição dependente e modificar a qualidade de sua inserção internacional.

De certa forma, pode-se dizer que o olhar e interesse desses pensadores brasileiros partiram da periferia da economia-mundo - de sua terra natal -, tendo suas análises focado nas realidades econômicas domésticas e no seu potencial para a autonomia do mercado interno e para a alteração das relações de dependência, mas sempre considerando os condicionamentos externos e sua estrutura cambiante. Já no que diz respeito às interpretações abordadas no capítulo anterior, estas partiram de um interesse pela compreensão da economia-mundo capitalista organizada a partir de seu centro de dinamismo econômico, e suas implicações cíclicas sobre o restante do sistema.

Neste sentido, a abordagem desses autores brasileiros encontra equivalência com as perspectivas totalizantes e de longo prazo desenvolvidas por Braudel, Wallerstein e Arrighi, ao buscarem elucidar o papel e evolução da economia brasileira dentro da lógica da economia-mundo capitalista existente desde o seu surgimento na Europa no século $\mathrm{XV}^{34}$. Ao se deterem sobre as realidades particulares da economia brasileira, não perderam de vista uma perspectiva totalizante e produziram importantes formulações originais.

Por fim, cabe ressalvar que não se pretende aqui realizar uma exaustiva revisão de todos os aspectos da história econômica do Brasil desde a formação da economia colonial, apesar da indiscutível relevância e mérito de tal esforço. Também não se pretende escrutinar a totalidade da obra desses importantes autores brasileiros. Para os objetivos desta pesquisa, nos interessa analisar como eles pensaram e trataram a inserção internacional da economia brasileira ao longo dos principais pontos de ruptura da sua trajetória histórica. Apesar de cada autor desenvolver suas formulações de modo particular e divergirem entre si em alguns pontos, todos são pensadores cujas análises foram motivadas pelas mesmas preocupações sobre as realidades e perspectivas da economia brasileira, tendo geral chegado a conclusões similares sobre o papel dos

\footnotetext{
${ }^{34}$ A opção pela visão de Arrighi (1996), que identifica o início do capitalismo histórico como sistema mundial (a "mundialização do capitalismo") com o fim da Idade Média na Europa, justifica-se pelo paralelo com o surgimento do sistema de Estados soberanos europeu. Conforme visto no capítulo um, existe forte consenso entre os autores estudados sobre o papel crucial da formação das alianças entre capital e poder político para promover a concentração de poder em determinados grupos capitalistas e governamentais que conseguiram assim conduzir os "ciclos sistêmicos de acumulação capitalista".
} 
determinantes externos, do mercado interno e da industrialização para a alteração das relações de dependência da economia brasileira.

Iniciaremos apresentando como esses intelectuais pensaram historicamente a intricada articulação entre a economia brasileira e a economia mundial desde nossa formação como colônia, para então focar em suas considerações acerca do potencial da economia nacional para construir seus próprios núcleos de dinamismo econômico, que necessariamente passa pela análise do potencial do mercado interno e do processo de industrialização. No limite, as suas incursões buscam avaliar a capacidade da economia brasileira de sustentar mecanismos endógenos de acumulação de capital e alterar seus laços de dependência com a economia-mundo capitalista. Se de um lado os três autores concedem, em graus diferentes, que o país conseguiu maior autonomia sobre a gestão de sua economia interna, de outro lado, encontra-se também um consenso de que mesmo assim o Brasil jamais logrou sair do perímetro das relações de dependência do tipo centro-periferia.

\subsection{O BRASIL E A INSERÇÃO INTERNACIONAL DE SUA ECONOMIA: UM ESTILO DE PENSAMENTO, VÁRIAS INTERPRETAÇÕES}

Parece ser consenso entre as interpretações desses três pensadores a importância dos fatores sistêmicos para a construção e transformação da estrutura socioeconômica brasileira. Tanto Prado Jr., quanto Furtado e Rangel explicam, cada um à sua maneira, a evolução histórica da economia brasileira a partir de suas ligações com a economiamundo capitalista. Assim, a primeira seção aponta a visão de cada autor sobre como a economia brasileira se estruturou a partir da dinâmica historicamente instável dos interesses econômicos do capitalismo mundial.

No entanto, o consenso se desfaz no que diz respeito à capacidade mostrada historicamente pelo país de alterar seus laços de dependência e subordinação econômica aos ditames da economia-mundo capitalista: cada uma dessas três interpretações produz uma avaliação diversa sobre o significado do potencial do mercado interno e da industrialização, e dos seus resultados em termos de uma melhor inserção internacional. Essas três avaliações são o objeto das próximas subseções, sendo sumarizadas na síntese 
do capítulo. Optou-se pela divisão em três subseções, visando a melhor organização das ideias desses autores: a primeira focando no papel dos determinantes externos, a segunda no potencial do mercado interno, e a última no significado da industrialização.

\subsubsection{A visão sistêmica: $O$ peso dos determinantes externos}

Em seu livro Formação do Brasil Contemporâneo, Prado Jr. (2004) introduz sua visão do "sentido" da evolução de um povo, definido como a essência que caracteriza e norteia a história de uma sociedade ${ }^{35}$, "seja qual for o momento ou aspecto dela que interessa, porque todos os momentos e aspectos não são senão partes, por si só incompletas, de um todo" (p. 19). No caso do Brasil, este sentido deveria ser buscado primordialmente a partir de seus entrelaçamentos econômicos com o mundo exterior, porque somente dentro do panorama maior da história europeia, em particular da história de sua expansão comercial ultramarina a partir do século $\mathrm{XV}$, que se poderia explicar o evento da colonização brasileira: "o Brasil não é senão um episódio, um pequeno detalhe daquele quadro imenso [...]. É apenas a parte de um todo, incompleto sem a visão deste todo" (PRADO JR., 2004, p. 20).

Esta visão sistêmica permeia toda a interpretação do autor sobre a evolução da economia brasileira, fundamentando-se no entendimento de que estudar a história nacional requer abordar o quadro mais abrangente da história mundial, e de que a evolução de nossa economia não é totalmente apreendida sem considerar a dinâmica maior da economia-mundo capitalista. Assim, para Prado Jr., a economia brasileira nasceu e se formou a partir dos interesses do comércio ultramarino europeu, erguendo uma estrutura produtiva voltada aos mercados externos que se enraizou de tal forma no sistema econômico brasileiro que o país nunca conseguiu se libertar de fato, permanecendo ao longo de sua história uma economia dependente e à mercê das vicissitudes da economia-mundo capitalista.

No entanto, o autor concede também que o país logrou alterar ao longo de sua história esses vínculos de dependência, ainda que os substituindo por outros, e que essas

${ }^{35}$ Em sua concepção, esse "sentido" seria uma soma de elementos essenciais orientados ao longo do tempo em torno de um eixo central, uma "linha mestra", que define o caráter e individualidade daquele grupo social no tempo e no espaço. Esse sentido é afetado tanto por elementos internos a ele quanto por forças externas e completamente exógenas à sua estrutura. 
novas formas relacionais mostraram-se fontes renovadas de dinamismo e transformações importantes na economia brasileira. Por exemplo, Prado Jr (1945, p. 127-131) destaca como a vinculação ao capital inglês no século XIX iniciada com os primeiros empréstimos britânicos logo após a Independência, em substituição aos laços coloniais com Portugal, teve um papel essencial para as importantes transformações da estrutura produtiva brasileira nesse período, impulsionando a modernização de sua economia, a expansão de seu mercado interno e o fortalecimento das forças produtivas nacionais.

Em sua visão, o capital britânico visava a consolidar a autonomia política brasileira para assegurar com isto seu acesso comercial, servindo destarte aos interesses de expansão de mercados das indústrias inglesas.Com esses objetivos, não só foram concedidos empréstimos à lavoura do café, que logo se tornou o dínamo da vida econômica do Brasil, mas também foi oferecido apoio técnico e financeiro a empreendimentos industriais e à infraestrutura brasileira. Com o capital inglês construíram-se indústrias, estradas de ferro, infraestrutura urbana, portuária e de fornecimento de energia elétrica, contribuindo grandemente para estimular a economia brasileira. Junto a outros fatores, como a abolição do tráfico de escravos e a difusão do trabalho assalariado, a vinculação ao capital britânico foi fonte importante de transformação e dinamização da economia brasileira, em uma verdadeira remodelação da "vida material do Brasil".

Furtado (1965) vai mais além, analisando o peso desses elementos sistêmicos na formação brasileira para caracterizá-la como um processo de subdesenvolvimento econômico, e afirmando que não se explica a historia do subdesenvolvimento periférico sem a história de desenvolvimento dos países centrais da economia-mundo capitalista. Para o autor, ambos os processos de desenvolvimento e subdesenvolvimento estariam relacionados ao surgimento e consolidação "de um núcleo industrial, na Europa do século XVIII, que provocou uma ruptura na economia mundial da época e passou a condicionar o desenvolvimento econômico subsequente em quase todas as regiões da terra" (FURTADO, 1965, p. 171-172). Em consequência:

O efeito do impacto da expansão capitalista sobre as estruturas arcaicas variou de região para região, ao sabor de circunstâncias locais, do tipo de penetração capitalista e da intensidade desta. Contudo, a resultante foi quase sempre a criação de estruturas híbridas, uma parte das quais tendia a comportar-se como um sistema capitalista, e a outra, a manter-se dentro da estrutura preexistente. Esse 
tipo de economia dualista constitui, especificadamente, o fenômeno do subdesenvolvimento contemporâneo. (FURTADO, 1965, p. 173).

Nesse sentido, ao confrontar os elementos de expansão internacional capitalista com as estruturas pré-existentes da periferia, Furtado (1965) mostrou-se adiantando à proposta pós-colonialista de Chakrabarty (2007) de inadequação e simultânea indispensabilidade da "tradição intelectual europeia" na análise das realidades periféricas. Apesar de não explicar a condição brasileira sem abordar as estruturas e dinâmicas do centro da economia-mundo capitalista, Furtado critica o uso da teoria clássica como modelo explicativo universal do processo de desenvolvimento econômico, apontando em especial a "falha fundamental de ignorar que $o$ desenvolvimento econômico possui uma nítida dimensão histórica” (1965, p. 158). Em sua concepção, aplicar aos países subdesenvolvidos os modelos clássicos, que são construídos a partir das particularidades históricas específicas dos países desenvolvidos, é um anacronismo.

Ou seja, Furtado (1965) confronta o processo histórico de desenvolvimento dos países centrais com o de subdesenvolvimento dos países periféricos para mostrar que tanto um quanto o outro resultaram de processos históricos próprios, frutos das condições específicas daqueles países. Ele mostra que as singularidades da evolução histórica da estrutura doméstica dos países periféricos foram cruciais, de tal modo que deveriam ser objeto de formulações explicativas próprias às suas especificidades e adequadas às suas realidades. (FURTADO, 1965, p. 173-177)

Assim, o autor define o subdesenvolvimento como um processo histórico particular derivado da incorporação de estruturas produtivas "arcaicas" a uma divisão internacional de trabalho em expansão a partir de seu núcleo industrial, que tiveram que se adaptar à lógica deste sistema, gerando estruturas "híbridas". O subdesenvolvimento não se refere, portanto, a uma etapa de um "processo de desenvolvimento", nem tem a ver com a "idade" do país ${ }^{36}$. O ingresso de economias como a brasileira na divisão internacional de trabalho teve razões puramente comerciais, visando integrá-las ao circuito comercial europeu como fornecedoras de primários e consumidoras de

\footnotetext{
${ }^{36}$ Furtado chega a chamar as interpretações ortodoxas que identificam o subdesenvolvimento como um "estágio" de um "processo de desenvolvimento" de "o Mito das ideias sobre desenvolvimento econômico" (1974, p. 16). Para o autor, essas ideias pressupõem uma crença irreal de que a experiência de desenvolvimento e consumo dos países europeus pode ser universalizada e aplicada a outras realidades completamente diferentes.
} 
manufaturados europeus ${ }^{37}$. A consequência foi a criação de estruturas "subdesenvolvidas" ou "híbridas", caracterizadas pela heterogeneidade tecnológica, socioeconômica e regional - resultado da adaptação dos seus recursos locais às exigências do comércio internacional conforme as condições domésticas.

A partir de outro viés analítico, Rangel (1957,p. 296-322) também reconhece o peso de ambos os determinantes externos e as estruturas internas ao analisar como a economia brasileira sempre teve que se adaptar às circunstâncias externas, em uma relação de dependência ou complementaridade que contribuiu decisivamente para a característica heterogeneidade da sociedade brasileira.Na visão do autor, a evolução da economia brasileira não é autônoma, não resultando apenas de suas forças internas, mas sim: "desenvolve-se como complemento de outras economias - dos países que, sucessivamente, ocupam a vanguarda no desenvolvimento da humanidade"(RANGEL,1957,p. 322).

Usando uma terminologia própria para abordar essa heterogeneidade, Rangel (1957) classifica a economia brasileira como "peculiar" por apresentar em seu território diversos "tempos econômicos" convivendo e interagindo entre $\mathrm{si}^{38}$, como resultado do seu tradicional inter-relacionamento entre "forças econômicas internas e externas". Por exemplo, para o autor, as "fazendas de escravos da colônia" não eram isoladas dos processos capitalistas mundiais, se articulando com eles por meio de circuitos comerciais controlados pelo capital mercantil português, constituindo uma forma original mista que combinava o "escravismo" com o "capitalismo mercantil". (RANGEL, 1957, p. 297)

Segundo o autor, esse padrão de interação entre formas econômicas internas e externas permeou de modo dinamicamente evolutivo a economia brasileira ao longo de sua história, caracterizando e permanecendo ainda hoje presente em seu complexo estrutural. Devido a essa dinâmica de interações mútuas, as teorias econômicas convencionais não podem ser aplicadas como ferramentas explicativas do

\footnotetext{
${ }^{37}$ Furtado (1965, p. 177) aponta que isso explicaria por que a expansão internacional decorrente do desenvolvimento industrial europeu no século XIX tomou a forma de expansão do comércio e não da indústria.

${ }^{38}$ Segundo Rangel (1957, p. 293), a economia brasileira apresenta simultaneamente as várias "etapas do desenvolvimento econômico humano": o comunismo primitivo das tribos selvagens; algumas formas de escravidão em áreas retrógradas; o feudalismo disperso por todo o país; o capitalismo em todas as suas "etapas": mercantil, industrial e financeiro; e o capitalismo de Estado. Todas essas formas convivem no espaço brasileiro, algumas abrangentes e dominantes, outras resquícios de épocas passadas. Evidencia-se assim, as interfaces dessa visão com a definição de Furtado sobre a condição do subdesenvolvimento, caracterizado por uma heterogeneidade tecnológica, socioeconômica e regional.
} 
funcionamento da economia brasileira: cada conjunto de leis econômicas não pode ser aplicado imutavelmente à sua forma econômica correspondente, "porque sua ação é perturbada pela ação de outras leis de natureza diferente" (RANGEL, 1957, p. 291).

Portanto, assim como Furtado, Rangel questionou a "universalidade" do pensamento europeu, ao ressaltar que, como as realidades econômicas apresentam um aspecto histórico-espacial, as leis aplicáveis a uma economia específica não se aplicam necessariamente a outra economia de época, local e estrutura diferentes. Em consequência, o autor considera que as "leis da ciência" sempre acabam por perder sua rigidez no tempo e espaço: "tornaram-se históricas, isto é, definem o comportamento da realidade em certas circunstâncias e valem apenas enquanto estas perduram" (RANGEL, 1957, p. 287).Analogamente, os dogmas da economia "clássica" não são universais, aplicando-se a apenas uma fase ou parte da ciência e da história econômica.

Portanto, o uso das teorias econômicas convencionais, como explicativas do funcionamento de partes da economia brasileira ou como referências para o seu desenvolvimento, devem levar em conta as realidades socioeconômicas específicas à nação e à sua evolução dinâmica, o que, como vimos, corresponde também ao pensamento de Prado Jr. e Furtado.Desse modo, como resultado desse complexo dinamicamente evolutivo, em que diferentes formas econômicas interagem entre si, para Rangel (1957) existiriam "leis" próprias e peculiares da economia brasileira. Essas leis não constituem uma mera justaposição, mas decorrem de um inter-relacionamento dinâmico de constante conflito entre as partes, em que uma busca se impor à outra. Tem-se assim uma realidade complexa, original e em permanente mudança.

Acima de todas as leis econômicas atuantes sobre a economia brasileira, Rangel identifica o império da influência de duas ordens principais de leis, que regem os rumos da economia nacional e de cada uma de suas formas econômicas: a que governa suas "relações internas de produção" e a que conduz suas "relações externas de produção"39. Esses dois grupos de leis são determinantes,apesar de as demais leis também influírem sobre o complexo econômico brasileiro de modo não impositivo (RANGEL, 1957, p. $297)^{40}$.

\footnotetext{
${ }^{39}$ Cabe ressaltar que essas categorias correspondem a apropriações particulares de Rangel das categorias definidas por Marx, não guardando relação de correspondência com as formulações feitas pelo pensador alemão.

${ }^{40}$ Segundo Rangel, as duas ordens de leis econômicas (externas e internas) se inter-relacionaram ao longo de toda a história brasileira: a "economia feudal europeia" que incorporou a "economia comunista primitiva ameríndia"por meio do capital mercantil ibérico; a "economia mercantil semifeudal europeia" promovida pela Holanda e Inglaterra e a "economia escravista colonial" brasileira; a "economia
} 
Isto é o que Rangel chama de "dualidade básica", que para ele constitui a "lei fundamental da economia brasileira" (1957, p. 298). Segundo esta lei, a economia brasileira só pode ser entendida a partir de suas "relações de produção internas e externas", que se espelham individualmente em cada forma econômica nacional, e cuja origem encontra-se no fato de o Brasil ter se desenvolvido de forma complementar e periférica a nações estrangeiras. Desse modo, a "dualidade" se reflete em todos os aspectos da sociedade brasileira, pela construção em seu território um "edifício original da combinação entre peças de culturas importadas não coetâneas” (RANGEL, 1957, p. 299).

No caso da economia brasileira, a dualidade aparece na existência de duas economias dominantes que imperam no campo das "relações internas e externas de produção" e que regem todos os níveis da economia brasileira. Entre essas duas ordens de leis, compatibilizando-as e tornando possível o relacionamento entre elas, Rangel destaca sempre existir um "personagem central" que interage com os demais agentes internos e externos, sendo essencial ao funcionamento do sistema. Esse papel foi exercido por diversos agentes ao longo da nossa evolução econômica: o "capital mercantil português", o "capital mercantil nacional" e, por fim, o "capitalismo de Estado" (RANGEL, 1957, p. 298).

Portanto, o autor elabora sua própria visão do inter-relacionamento entre a economia brasileira e a economia-mundo capitalista, definindo a existência de duas ordem fundamentais de leis econômicas, internas e externas, ambas essenciais na determinação da originalidade e heterogeneidade da economia brasileira, cujo relacionamento foi intermediado por diferentes atores ao longo da história, com destaque para o Estado no seu momento mais recente.

Em suma, apesar de veiculadas por construtos teóricos e conceituais diversos, em muitos aspectos, as análises de Prado Jr., Furtado e Rangel convergem para a necessidade de compreender o relacionamento da economia brasileira com os centros externos de dinamismo econômico, como pré-requisito para o estudo da evolução de seu complexo estrutural e qualidade de sua inserção internacional. Seja esse relacionamento abordado por meio do "sentido da colonização" de Prado Jr., do "fenômeno do subdesenvolvimento" de Furtado, ou da "lei da dualidade básica" de Rangel, seus

capitalista industrial europeia" e a "economia mercantil nacional independente"; e as contemporâneas "economia capitalista financeira mundial" e a "economia latifundiária, semi-industrial e com mercado doméstico nacional" (1957, p. 302-303). 
significados convergem: a construção e transformação da economia brasileira foram condicionadas pelos interesses da economia-mundo capitalista de modo fundamental, cujo encontro com as estruturas produtivas pré-existentes levou à consolidação de um complexo heterogêneo cujo grau de autonomia em relação ao sistema internacional revelou-se bastante limitado, o que entretanto deve ser compreendido nas várias configurações históricas.Ou seja, até aqui a diferença de métodos e enfoques entre autores não impede que estes cheguem a conclusões semelhantes. No entanto, como será abordado nas próximas seções, a evolução em direção à conquista de maior autonomia da economia brasileira foi interpretada de diferentes modos por esses três intelectuais.

\subsubsection{O potencial do mercado interno}

De certa forma, a avaliação de cada autor sobre a capacidade da economia brasileira de exercer maior autonomia em relação à economia-mundo capitalista passa, em um primeiro momento, pelas suas interpretações individuais acerca do potencial do mercado interno do país. Passando de "insuficiente" até "fator de dinamismo", e a depender do período analisado, percebem-se visões muito distintas sobre a envergadura da economia brasileira para sustentar endogenamente seus próprios processos de expansão de mercados e acumulação de capital, com diferenças aguçadas entre os diagnósticos de cada pensador sobre a industrialização.

Para Prado Jr., o "sentido da colonização" brasileira permaneceu enraizado de tal forma em sua estrutura socioeconômica que o país nunca conseguiu se libertar de forma significativa de seus laços de dependência com os mercados mundiais. Por ter nascido e se formado dentro dos interesses do comércio ultramarino europeu, o autor aponta que a economia brasileira originalmente constituiu-se "uma economia colonial, no sentido mais preciso, em oposição ao que denominaríamos uma economia 'nacional', que seria a organização da produção em função das necessidades próprias da população que dela participa" (PRADO JR., 1945, p. 270).

Essa falta de correspondência entre a produção nacional e as necessidades da maioria da população, em que no geral a estrutura produtiva brasileira visou às exportações e gastou o excedente auferido para importar bens de consumo de luxo da 
minoria dominante, acompanhou a evolução econômica nacional, sendo um dos principais obstáculos à constituição de uma estrutura produtiva coerente e adequada ao desenvolvimento econômico do país, de modo dinâmico e endogenamente determinado.Prado Jr. (2004, p. 273) aponta que,por meio deste mecanismo, exportando primários e importando manufaturados, a dependência estrutural da economia brasileira das circunstâncias externas se reforçou. Tudo o que não apoiasse os objetivos de lucro nos mercados mundiais via exportações de primários, qualquer atividade ou ocupação estranha a esta orientação exógena, ficava relegada a um segundo plano, sem expectativas de consolidação e florescimento, ao menos durante o período colonial.

Assim, o autor identifica que apenas as duas classes necessárias para garantir a grande empresa colonial iriam compor o grosso da sociedade brasileira: a minoria dos senhores proprietários de terras e os dirigentes da produção, e as massas de escravos trabalhadores ${ }^{41}$. Como resultado, o "mercado interno" brasileiro acabou sendo formado por uma minoria consumidora de bens de alto padrão importados e por uma grande massa sem poder aquisitivo - constituindo assim uma demanda interna débil e incapaz de sustentar endogenamente uma acumulação de capital significativa e dinâmica.

Esta estrutura socioeconômica e seu mercado consumidor são vistos por Prado Jr. (1989, p. 49-50) como o principal obstáculo ao desenvolvimento nacional, por impedir a diversificação produtiva e limitar a capacidade do país de sustentar e controlar o seu próprio crescimento econômico.

Desse modo, Prado Jr. (1989) destaca que os fatores sistêmicos permaneceram determinantes em nossa trajetória, apesar de reconhecer que elementos próprios e organicamente definidos revelar-se-ão aos poucos para compor um novo "sentido" da economia brasileira, marcando a direção de sua evolução e desempenhando um papel relevante para os rumos do desenvolvimento do país. Para o autor, o peso dos elementos sistêmicos é um fator que se mantém indelével em todos os momentos e aspectos de nossa evolução, desde a economia colonial até a contemporânea:

Um passado ainda tão recente pesa na situação atual cuja análise e interpretação não podem assim prescindir de suas premissas históricas [...] o Brasil de hoje, apesar de tudo de novo e propriamente contemporâneo que apresenta [...] ainda se acha intimamente entrelaçado com o seu passado. E não pode por isso ser entendido

\footnotetext{
${ }^{41}$ Segundo Prado Jr. (2004), devido à falta de atividades remuneradoras fora do circuito da grande lavoura exportadora, ou que fossem acessíveis aos destituídos de recursos, formou-se também uma massa crescente de indivíduos desclassificados socialmente, os chamados "homens pobres livres", marginalizados da sociedade (p. 280-284).
} 
senão na perspectiva e à luz desse passado. (PRADO JR., 1989, p. 1819).

Nesse sentido, o autor aponta que mesmo os impulsos propulsores do enfraquecimento da ordem colonial também se originaram de desdobramentos exógenos: "fundamentalmente da nova ordem internacional que se vem configurando no correr da segunda metade do séc. XVIII, e se precisa e consolida no correr do século seguinte [...] o capitalismo industrial" (PRADO JR., 1989, p. 51). Para o autor, a substituição do domínio do "capital comercial" lusitano e seus monopólios mercantis pelo "capital industrial" britânico abalou o sistema do qual o Brasil fazia parte, configurando uma situação nova no panorama internacional para o país recémemancipado: a ampliação e diversificação dos seus mercados internacionais, e o acesso a novas tecnologias, equipamentos e financiamentos.

Desta forma, na visão de Prado Jr. (1989, p. 54-55), a nova feição industrial do sistema capitalista mundial abriu oportunidades para o início de um lento "processo de desenvolvimento moderno".No entanto, o autor enfatiza que, mesmo com a alteração do sistema capitalista mundial e suas implicações "modernizantes" para o Brasil, a essência e sentido dos rumos da evolução econômica brasileira não haviam mudado. Apesar de o Brasil ter ganhado a autonomia política, a nova nação manteve sua orientação econômica externa, com a organização produtiva direcionada aos mercados mundiais e deles dependente. A ex-colônia manteve sua posição periférica de fornecedor de primários na economia mundial, somente agora liberta do rígido monopólio colonial.

Para Prado Jr.(1989, p. 58-61), a grande expressão desse fenômeno foi o sucesso da produção cafeeira. Mantendo a essência da tradicional atividade agrário-exportadora, o café foi beneficiado pelo fim do monopólio comercial e do isolamento político colonial, que ampliou seus mercados consumidores e permitiu a participação dos capitais e tecnologias estrangeiras na criação de uma infraestrutura de transporte da produção (redes ferroviárias, navios a vapor) e no financiamento da lavoura. E, principalmente, junto com a abolição da escravidão e a imigração, impulsionou a formação de uma massa de trabalhadores livres, possibilitando a constituição de um mercado consumidor nacional.

Segundo o autor, poder-se-ia quase dizer que se preparou o terreno para a atividade manufatureira, garantindo-lhe os elementos decisivos ao seu florescimento: o mercado consumidor, a acumulação de capitais, e a instituição do trabalho livre 
assalariado. No entanto, apesar de avaliar que nesse período "expandem-se então largamente as forças produtivas brasileiras, dilatando-se o seu horizonte" (PRADO JR., 1945, p.192), o autor pondera que tais avanços foram insuficientes para quebrar as redes de dependência externa, não tendo sido progressos que foram endogenamente criados e alimentados, mas que constituíram na realidade uma resposta à nova lógica do "capital industrial".

Já Furtado, pelo menos inicialmente, acreditava na possibilidade de uma transformação estrutural da economia brasileira capaz de reverter o quadro de subdesenvolvimento. Nos anos 1950, buscando compreender os processos de desenvolvimento e subdesenvolvimento, Furtado(1965,p. 180-182) analisou o desenvolvimento como um processo sustentado pela inovação tecnológica, com o aumento da produtividade do trabalho sendo acompanhado do incremento da sua respectiva renda - portanto,implicando na alteração consequente da demanda, em um processo autossustentado de acumulação de capital e desenvolvimento.

Assim, o autor identifica que, se nesse processo de desenvolvimento industrial do centro o "elemento dinâmico" foi a oferta (o avanço tecnológico como promotor da acumulação sistemática, elevando a produtividade com correspondente ganho salarial), enquanto que nos países periféricos a oferta não teria cumprido esse papel, tendo em vista que sua fonte de estímulo fora tradicionalmente exógena ao país.Na realidade, o autor enfatiza haver uma tendência estrutural ao estrangulamento externo da economia brasileira,decorrente de sua dependência das exportações e importações para suprir as necessidades de consumo do país, apontando que o caminho para o desenvolvimento estava na industrialização nacional, e na integração das economias regionais para a formação do mercado interno, em um plano estratégico conduzido pelo Estado ${ }^{43}$.

Para o autor,a "criação de um núcleo industrial, tornando possível, com o tempo, a transformação estrutural da economia” (FURTADO, 1965, p. 180). Naquela época, Furtado (1965, p. 184-185) ainda acreditava que a industrialização promoveria a

\footnotetext{
${ }^{42}$ Na passagem para a República, o autor aponta que a população brasileira crescera consideravelmente, os sistemas de transportes e comunicações tivera importantes avanços, a vida financeira do país se iniciara e a atividade manufatureira ensaiava alguns passos: "a antiga colônia segregada e vegetando na mediocridade do isolamento, se moderniza e se esforça por sincronizar sua atividade com a do mundo capitalista contemporâneo" (PRADO JR., 1945, p. 192-195).

${ }^{43}$ Para Furtado (1965, p. 185), esse problema poderia ser contornado incentivando uma industrialização que induzisse inovações tecnológicas adequadas à realidade socioeconômica brasileira, aproveitando os excedentes de trabalho e a abundância de primários. Esta deveria ser acompanhada de uma reforma agrária que contivesse o êxodo rural e impulsionasse a integração das zonas agrárias às urbanas.
} 
formação de uma massa local de salários, impulsionando a modernização dos hábitos de consumo dos trabalhadores, e contribuindo para sustentar um processo endógeno de acumulação sistemática à semelhança do ocorrido no centro. Para isso, o autor considera crucial a ação do Estado na redução das desigualdades sociais e regionais, restringindo o uso do excedente para importação de bens de luxo pela minoria dominante. Em sua visão, a eleição do Estado como comandante desse processo justificava-se por ser o único agente capaz de empreender as realocações de recursos necessárias, realizando os ajustes cabíveis para evitar a tendência ao estrangulamento externo.

Na realidade, conforme nota Bresser (1977, p. 201-203), Furtado fazia parte de uma geração de economistas envolvidos com os problemas do desenvolvimento (e do subdesenvolvimento), que atuavam no bojo das discussões pós-Segunda Guerra Mundial, quando foi despertado o interesse generalizado pelo desenvolvimento dos países da periferia. Nesse contexto, o planejamento estatal era visto por Furtado e por seus companheiros de geração ${ }^{44}$ como a solução para conduzir a industrialização e as transformações socioeconômicas necessárias à superação da heterogeneidade periférica. Ainda mais tendo em vista o agravamento da tendência desses países ao estrangulamento externo durante a turbulência internacional entre a Depressão dos anos 1930 e a Segunda Guerra Mundial, a industrialização surgia como a solução para os problemas de balanço de pagamentos e restrição externa, abrindo o caminho para o desenvolvimento.

No entanto, mesmo nos anos 1960 já era visível que, apesar do avanço do processo de industrialização, este não fora acompanhado pelo desenvolvimento esperado e, pelo contrário, levou a uma redefinição dos canais de dependência do tipo centro-periferia, com avanços significativos em alguns aspectos, mas também com pioras acentuadas em outros. Apesar do crescimento da acumulação de capital, a industrialização ocorrera sem distribuição de renda e efetiva integração econômica nacional, piorando pelo contrário a concentração de renda e as desigualdades regionais, mantendo o poder de compra das massas reduzido e concentrando a industrialização na reprodução dos bens antes importados pelas elites. (BRESSER, 1977, p. 204-205)

Destarte, Furtado (1974) realiza uma revisão de suas posições em relação à possibilidade de reverter o processo de subdesenvolvimento brasileiro por meio da

\footnotetext{
${ }^{44}$ Conforme Bresser (1977, p. 202), entre esses estavam pensadores tanto de países desenvolvidos, como Myrdal, Singer e Perroux, como de países subdesenvolvidos, como Prebisch, Furtado e Aníbal Pinto. Em comum, todos tinham o envolvimento com os problemas do desenvolvimento e do subdesenvolvimento.
} 
industrialização. Buscando explicar as razões dessa falha, o autor chega a considerar o processo de desenvolvimento tradicional como um "mito", apontando a necessidade indispensável de realizar reformas na estrutura socioeconômica, redistribuindo a renda, promovendo a reforma agrária e reorientando as lógicas de produção e acumulação. Além disso, Furtado enfatiza o significado da expansão das atividades de empresas multinacionais na periferia nos anos 1960 (1974, p. 15), instalando filiais cujas decisões e processos de inovação e tecnologia permaneceram sendo realizados em suas matrizes no centro da economia-mundo capitalista. A presença crescente das multinacionais reforçou o caráter "imitativo" do processo de industrialização, uma vez que suas filiais empreenderam reproduções defasadas dos produtos criados no centro, perpetuando ainda a dependência tecnológica da periferia dos núcleos de dinamismo capitalista.

Caracterizando o processo de industrialização ocorrido no Brasil como "modelo brasileiro de subdesenvolvimento", Furtado (1974, p.77-94) concluiu que, mais do que subdesenvolvido, o Brasil era "dependente", definindo essa condição como uma de "dependência cultural", posto que derivada da tendência da elite dominante a usar o excedente nacional em importações de bens de consumo para imitar os padrões de vida europeus. Assim, o excedente gerado não era investido no processo produtivo, não gerando avanço tecnológico nem incrementando a acumulação de capital, ao contrário do ocorrido nos países centrais, cujos grupos dominantes tinham interesse em usar sistematicamente o excedente para dinamizar a acumulação de capital por meio de inovações e aumentos de produtividade.

Para Furtado (1974, p. 78-83), esta teria sido a diferença fundamental que levou respectivamente ao subdesenvolvimento ou desenvolvimento: o uso do excedente para a "modernização" dos padrões de vida no primeiro caso, ou para o incremento sistemático da acumulação de capital por meio da melhora do processo produtivo no último caso. Em sua visão, a condição de dependência precede à de subdesenvolvimento: enquanto dependência diz respeito à situação particular de países cujos padrões de consumo são modelados a partir do exterior, subdesenvolvimento diz respeito à característica de países com profunda heterogeneidade socioeconômica, tecnológica, setorial e regional.Porém, a dependência não necessariamente leva ao subdesenvolvimento:

[...] o fenômeno que chamamos dependência é mais geral do que o subdesenvolvimento. Toda economia subdesenvolvida é necessariamente dependente, pois o subdesenvolvimento é uma criação da situação de dependência. Mas nem sempre a dependência criou as formações sociais sem as quais é difícil caracterizar um país como subdesenvolvido. (FURTADO, 1974, p. 87). 
Portanto, a velha dependência comercial foi superada por uma nova forma de dependência, manifestada pela transferência de tecnologia do centro para a periferia para que uma minoria dominante desta possa replicar os padrões de consumo daquele.Nessa nova condição, embora houvesse crescimento econômico e progresso tecnológico, a marginalização das massas e a heterogeneidade socioeconômica e regional tenderam a piorar, acentuando a divisão nacional em um setor "moderno" e dinâmico, produtor de bens de luxo para consumo das elites, e outro "tradicional" relativamente estagnado, produtor de bens agrícolas e de consumo básico para a massa de trabalhadores remunerados ao nível de subsistência.

Em síntese, o que caracterizou a formação da periferia foi a dinamização da demanda - modernização - em condições de um relativo imobilismo social causado pelo lento desenvolvimento das forças produtivas. [...]uma dessimetria entre sistema produtivo e sociedade. Essa dessimetria manifesta-se na forma de heterogeneidade social (FURTADO, 2000, p. 81-82).

Para o autor, esse "processo de colonização cultural” iniciou-se na colônia, com a introdução de padrões de consumo estrangeiros que só podiam ser mantidos com o excedente gerado pelas exportações ${ }^{45}$, gerando dependência tanto pelo lado da crescente especialização na exportação de primários, quanto pelo lado da também crescente necessidade de importar. Diante do inevitável resultado de piora das contas externas, Furtado (1974, p. 81) identifica duas respostas disponíveis a esses países: aumentar as exportações; ou reduzir as importações e promover a industrialização nacional visando prover a demanda interna com produção interna.

Porém, conforme o autor, a primeira opção era limitada, visto que as exportações não poderiam ser expandidas indefinidamente; enquanto a segunda opção manteve a dependência externa, uma vez que foi uma industrialização nascida para substituir importações, ou seja, que se manteve restrita à produção para imitar produtos europeus para consumo da minoria dominante, sem promover avanços significativos na acumulação de capital nem na estrutura socioeconômica brasileira. Daí a sua caracterização do processo de industrialização pós-Segunda Guerra não como um modelo de desenvolvimento, mas de subdesenvolvimento, na medida em que não eliminou a heterogeneidade socioprodutiva nacional nem a sua condição de

${ }^{45}$ Para Furtado (1974, p. 85-86), esse "processo de colonização cultural", teria ocorrido mesmo nas colônias temperadas que vieram mais tarde a integrar o centro do sistema, que apesar de terem o aumento do nível geral de salários e um processo de industrialização considerável, permaneceram dependentes das tendências de consumo externas. 
dependência, mas piorou as desigualdades domésticas e apenas redefiniu os seus elementos de subordinação ao centro da economia-mundo capitalista.

É importante notar as diferenças entre esta visão de Furtado acerca do papel da demanda interna e a de Prado Jr.: para Furtado, a demanda doméstica foi central para a alteração das relações de dependência do país- de comercial para financeiro e tecnológico -, sendo identificada pelo autor como o "elemento dinâmico" que levou o país a se industrializar e promover transformações fundamentais em sua estrutura socioprodutiva, apesar de manter-se subdesenvolvido e dependente dos centros de dinamismo externo. Já para Prado Jr., a demanda interna foi um empecilho ao desenvolvimento do país, perpetuando a sua situação periférica ao restringir sua capacidade de sustentar endogenamente processos dinâmicos de acumulação, jamais chegando a constituir um mercado consumidor doméstico significativo e mantendo o setor externo como "fonte de dinamismo" da economia nacional.

Ou seja, Furtado reconhece que, se por um lado mantiveram-se as condições de subdesenvolvimento e dependência externa, por outro lado houve uma importante transformação estrutural da economia brasileira, que se industrializou e se modernizou, ingressando em uma nova qualidade de inserção internacional formatada por novos tipos de dependência do centro da economia-mundo capitalista. Ele avalia também que, sem os incentivos da demanda brasileira, esse processo de transformação não teria sido possível:“o impulso transformador é dado pela evolução da demanda. A expansão das exportações é condição necessária mas não suficiente para que ocorram as transformações, pois não exclui a hipótese de retenção do excedente no exterior" (FURTADO, 2000, p. 97).

De fato, o autor nota que os períodos de forte restrição externa provocaram na periferia um processo geral de reversão da especialização na exportação de primários e retorno às atividades de subsistência agrícolas e artesanais. Porém, alguns países periféricos com condições favoráveis, entre elas o tamanho do mercado interno e uma ação minimamente coordenada pelo Estado, conseguiram promover a industrialização, realocando recursos produtivos do setor exportador para os novos setores industriais em construção.

Destarte, os incentivos do mercado externo passaram a ter efeitos multiplicadores internos que se expressaram não nas fases de expansão (quando aumentava a capacidade de importar), mas nas de contração (quando reduzia a capacidade de importar), em decorrência do papel da demanda interna como elemento 
de dinamismo econômico. Essas estruturas subdesenvolvidas com um mercado interno relevante conseguiram atingir um estado de maior complexidade (o caso do Brasil), formando um núcleo industrial interno significativo. Nelas, o subdesenvolvimento pôde evoluir da simples coexistência entre a empresa exportadora e uma enorme economia de subsistência, até o caso mais complexo, agregado de um terceiro elemento industrial.

Por fim, como veremos adiante,a avaliação de Rangel sobre o papel da demanda interna brasileira se destaca por ir em uma direção diversa à de Prado Jr., ao menos no que diz respeito à segunda metade do século $\mathrm{XX}$, diferenciando-se também do diagnóstico elaborado por Furtado. Rangel propõe uma formulação teórica em que a questão da demanda interna se confunde intimamente com a da industrialização, de tal sorte que se considerou mais profícua a abordagem em conjunto de ambas as questões na próxima seção, em que a interpretação de cada autor sobre o significado da industrialização brasileira será apresentada.

\subsubsection{Desenvolvimento e industrialização: Endogeneizando os mecanismos de acumulação ou aprofundando a dependência?}

Embora tanto Prado Jr. quanto Furtado e Rangel pareçam concordar que o processo de industrialização nacional foi impulsionado pelos momentos de "estrangulamento" externo (crises internacionais que comprometeram a capacidade de importar brasileira) e permitido pela existência de uma demanda interna por manufaturados, suas interpretações diferem quanto ao significado dessa industrialização para a inserção internacional do país e para a redefinição das suas estruturas de dependência. De certa forma, pode-se dizer que tais diferenças interpretativas estão relacionadas às suas correspondentes visões sobre o potencial da demanda interna para sustentar endogenamente um processo nacional de acumulação sistemático, de modo a garantir o desenvolvimento do país.

Destarte, no caso de Prado Jr.(1989), o autor entende que a industrialização foi mais uma "etapa" de nossa evolução econômica que pode ser explicada a partir de elementos externos, ainda que ele não menospreze a existência de um dinamismo interno. Em sua visão, ao contrário do processo de industrialização autogerado e com dinamismo próprio ocorrido nos países centrais, a indústria brasileira foi avançando 
descontinuamente ao sabor de fatores exógenos. Em particular, ele aponta ter existido um "paralelismo entre a conjuntura industrial e as vicissitudes cambiais da moeda brasileira [...] Os grandes momentos de prosperidade da indústria serão sobretudo aqueles em que a moeda se desvaloriza" (PRADO JR., 1989, p. 74). E os momentos de desvalorização da moeda nacional coincidiram com aqueles de turbulências na economia mundial: a Crise de 1929 e as duas Guerras Mundiais.

Conforme o autor, a Grande Depressão marcou uma virada fundamental na evolução econômica nacional, ao dar por "definitivamente encerrada a brilhante trajetória passada da economia brasileira como função da exportação de gêneros primários" (PRADO JR., 1989, p. 70). Até então, apesar dos importantes avanços e da modernização dos padrões de vida, a quase total dependência nacional da exportação de produtos primários avançara durante o Império e as primeiras décadas da República, reproduzindo a velha evolução por ciclos de produtos de exportação: a concentração na produção de poucos gêneros exportáveis era importante fator de vulnerabilidade externa, e quanto maior essa concentração, mais vulnerável o país às oscilações dos mercados mundiais $^{46}$ (PRADO JR., 1989, p. 49-50).

A grande crise significou a contração dos mercados consumidores das exportações de primários e o encarecimento das importações devido à desvalorização cambial. Sem meios de atender às necessidades crescentes de divisas e precisando suprir o mercado interno, a diversificação produtiva nacional foi estimulada, libertando as atividades produtivas do "exclusivismo de uns poucos gêneros primários destinados à exportação" (PRADO JR., 1989, p. 73). Assim, surgiu um impulso de peso à manufatura nacional ${ }^{47}$ : o atendimento à demanda interna nos momentos de forte restrição externa.

Para Prado Jr., esses fundamentos sobre os quais se ergueu a indústria nacional foram extremamente precários e limitados: de um lado, não houve planejamento estatal, nem preparo administrativo ou atenção à sua viabilidade de longo prazo; e de outro lado, buscou-se apenas ocupar o vazio deixado pelas importações, compostas essencialmente pelas demandas de uma minoria abastada. Para isso, bastavam

\footnotetext{
${ }^{46}$ Foi assim, por exemplo, nos ciclos do açúcar, do ouro, do algodão, do tabaco, do café, da borracha e do cacau (PRADO JR., 1945, p. 157-159, 225-257).

${ }^{47} \mathrm{O}$ autor pondera que o primeiro surto considerável da manufatura brasileira ocorrera no fim do Império (1880-1889), se constituindo sobretudo em modestas unidades de poucos operários e pequena inversão de capital, essencialmente manufaturas locais de têxteis e alimentos. Com a Primeira Guerra (1914-1918), "as iniciativas industriais se multiplicam e o progresso se acentua" (PRADO JR., 1989, p. 73), mas ainda não na escala ocorrida durante a grande depressão.
} 
"indústrias fictícias, simples atividades de 'ajuntamento de peças"” (PRADO JR., 1945, p.262-263) para substituir as importações. O resultado foi "uma indústria desordenadamente implantada, sem outro critério que as excepcionais e tão artificiais facilidades oferecidas... uma indústria mal estruturada, de baixo nível tecnológico e financeiramente precária” (PRADO JR., 1989, p. 76-77).

Além disso, permanecia a dependência de máquinas e insumos industriais importados, de tal modo que, se por um lado a desvalorização cambial favorecia o processo de industrialização pelo encarecimento das importações, por outro lado prejudicava-o na medida em que encarecia também as importações desses elementos do processo produtivo industrial. Essa dependência piorava à medida que o processo de industrialização avançava, dificultando o seu progresso e expansão. Segundo o autor, somente após a Segunda Guerra foram iniciadas políticas de incentivo e proteção à atividade industrial,visando a resolver esses problemas e dando corpo a uma condução política que permitiu a ampliação do escopo e alcance da indústria nacional: “generaliza-se a substituição, e em pouco mais de um decênio se chegará à situação de somente importar aqueles artigos para cuja produção faltavam inteiramente recursos naturais ou tecnológicos" (PRADO JR., 1989, p. 76).

Mesmo assim, o autor aponta que a intervenção estatal não se deu por meio do incentivo ao progresso técnico e à melhora qualitativa da produção, mas apenas perpetuou uma indústria protegida e atrasada tecnologicamente. Isso porque, voltando à questão da demanda interna - o maior empecilho à transformação da estrutura socioeconômica brasileira na concepção de Prado Jr. -, a industrialização não visou um mercado consumidor que abrangesse o todo social, mas apenas uma minoria abastada. Em decorrência, não estabeleceu relação com as atividades sociais essenciais do país, resultando em uma estrutura produtiva inadequada à realidade socioeconômica brasileira:

a falta de paralelismo e correspondência entre, de um lado, o crescimento econômico do país e as necessidades gerais e fundamentais dele e do conjunto da população; e de outro lado, o ritmo do progresso industrial, uma vez que esta não se orienta pelas necessidades gerais [...]. O que se refletem, entre outras graves consequências, na falta de continuidade do processo de industrialização e progresso gradativo e sustentado dele; bem como numa defeituosa e altamente inconveniente distribuição e estruturação das atividades industriais, e em especial, no crescimento desproporcionado da produção de bens de consumo final. (PRADO JR., 1989, p. 80). 
Logo, a negatividade do processo de industrialização para Prado Jr. está na sua falta de interlocução com as necessidades da sociedade brasileira como um todo, da qual decorrem seus problemas e limitações. Paralelamente, permaneceram obstáculos importantes à verdadeira transformação da economia nacional, como o baixo nível econômico do país, limitador do processo de capitalização nacional, tornando-o lento e débil, resultando na dependência do capital estrangeiro ${ }^{48}$ (PRADO JR., 1945, p. 263264). Essa precariedade das bases financeiras nacionais deu grandes vantagens às empresas estrangeiras, de tal modo que "facilmente conquistaram as melhores posições na economia brasileira, ao ponto de 'o núcleo verdadeiramente dinâmico' da indústria brasileira se constituir em nada mais que uma constelação de filiais de empresas internacionais" (PRADO JR., 1989, p. 83) ${ }^{49}$.

Tudo isso porque "o acanhado mercado consumidor interno e sua defeituosa estrutura... não oferece os impulsos necessários para a promoção das atividades econômicas" (PRADO JR., 1989, p. 81). Para o autor, a costumeira ênfase no investimento e na acumulação de capital para o sucesso do processo de desenvolvimento advém de tentativas errôneas de explicar o subdesenvolvimento a partir das teorias clássicas do desenvolvimento, entendendo-o como uma "insuficiência das inversões" (PRADO JR., 1989, p. 23) em um momento recessivo do ciclo econômico.

No entanto, o autor avalia que, ao se confundir crescimento com ciclos econômicos, deixam-se de lado os processos históricos de cada país que explicam o seu desenvolvimento econômico em prol de ciclos de investimento e acumulação que acompanham as flutuações econômicas:

As inversões, e mesmo a circunstância geral que as condiciona e que vem a ser o processo da acumulação capitalista, muito pouco e quase nada informam relativamente à dinâmica do desenvolvimento [...] o que é preciso considerar é [...] em primeiro e principal lugar, a conjuntura mercantil, isto é, as características da demanda. Bem como as condições em que a produção se organiza, e as relações de

\footnotetext{
${ }^{48}$ A posição dominante do capital estrangeiro tendeu a reforçar a função periférica exportadora do país, devido à necessidade de divisas para o pagamento de juros a empréstimos internacionais e, mais tarde, pelas remessas de lucros de filiais estrangeiras às suas matrizes. Assim, a tradicional posição exportadora de bens primários retornou fortalecida pelo próprio avanço da industrialização, em uma nova subordinação externa (PRADO JR., 1989, p. 83).

${ }^{49} \mathrm{Na}$ realidade, as primeiras subsidiárias chegaram antes da Primeira Grande Guerra, visando a contornar tarifas alfandegárias e aproveitar a mão-de-obra barata e a facilidade de transporte. Eram dos setores de alimentação, veículos motores, produtos farmacêuticos e químicos, aparelhamento elétrico, entre outros, tendo tido importante contribuição ao desenvolvimento da indústria brasileira, sendo as principais responsáveis pelo estabelecimento da indústria de base do país, como a metalurgia do ferro (PRADO JR., 1945, p. 266-269).
} 
produção se estabelecem. É isto que condicionará o afluxo de capital, a formação e acumulação dele, e a resultante inversão produtiva que vem assim, pode-se de certa forma dizer, em último lugar (PRADO JR., 1989, p. 23-24).

Assim, o autor reforça a necessidade de retornarmos às raízes de nossa evolução histórica para delinear as premissas básicas do nosso desenvolvimento, pois compreendê-lo é realizar uma análise historiográfica, buscando em nosso passado e no sentido de nossa formação socioeconômica os elementos essenciais que ainda se expressam nas problemáticas atuais. Portanto, na visão de Prado Jr., o Brasil permaneceu condicionado pelos centros de dinamismo capitalista, porque sua indústria nasceu e se formou dependente dos capitais e tecnologias estrangeiros. Na realidade, em alguns momentos o autor até se recusa a ver um "processo de industrialização", entendendo que não foi uma verdadeira industrialização, pois apenas ocupou-se o vazio deixado pelas importações, sem haver planejamento, estratégia administrativa ou visão de longo prazo.

O autor até admite o surgimento de um novo tipo de capitalismo no Brasil, em que o país assume uma nova posição, ainda periférica, no que ele chama de "imperialismo" do sistema. Porém, a transformação da estrutura produtiva em direção à industrialização foi inadequada perante as necessidades da maioria da população, permanecendo incapaz de sustentar endogenamente um processo continuado de acumulação de capital. Em consequência, o país permaneceu subordinado ao capital internacional, que tendeu a reconduzi-lo à sua função periférica exportadora: para honrar as remessas do capital estrangeiro instalado no país era preciso exportar, reforçando a velha relação de dependência das exportações. Assim, o país retomou sua posição de fornecedor de primários para os mercados internacionais. (PRADO JR., 1974, p. 83).

Em termos gerais, assim como Prado Jr., Furtado aponta que foi só com as três grandes crises internacionais da primeira metade do século XX que se abriram novos caminhos à industrialização na periferia. No entanto, diferentemente de Prado Jr., Furtado ressalta que se não fosse pelo tamanho e força do mercado interno brasileiro, a redução da capacidade de importações teria apenas provocado a reversão da especialização produtiva anterior e o retorno às atividades de subsistência agrícolas e artesanais.

$\mathrm{Na}$ realidade, conforme visto, houve uma inflexão no pensamento de Furtado quanto a industrialização sob controle do Estado como modelo de desenvolvimento, que 
levou à sua evolução do Furtado defensor da industrialização (1965) para o Furtado desiludido de "O mito do desenvolvimento" (1974). Inicialmente Furtado (1965) acreditava que, apesar dos problemas estruturais do país, como sua heterogeneidade sociorregional e dependência externa, a condução estatal dos investimentos industriais seria capaz de impulsionar "a transformação estrutural da economia" (p. 180) por meio de efeitos multiplicadores internos:

Nas estruturas subdesenvolvidas mais complexas - onde já existe um
núcleo industrial ligado ao mercado interno - podem surgir reações
cumulativas, tendentes a provocar transformações estruturais no
sistema. O fator dinâmico básico continua a ser a procura externa; a
diferença está em que a ação desta é multiplicada internamente.
(FURTADO, 1965, p. 182).

No entanto, após alguns anos de industrialização, diante do agravamento de alguns aspectos do subdesenvolvimento, como a desigualdade sociorregional e a redefinição dos laços de dependência externa - dos capitais e tecnologias estrangeiros, além do controle de parte importante do parque industrial por empresas multinacionais , o autor passa a caracterizar a industrialização brasileira, não como um modelo de desenvolvimento, mas como um de "subdesenvolvimento industrializado" (FURTADO, 1972, p. 14). Ou seja, a despeito do sucesso relativo na implementação de um setor industrial e de uma economia mais complexa e diversificada, agravaram-se as desigualdades sociais, a concentração de renda e a dependência dos capitais e tecnologias estrangeiras.

Portanto, se de início o autor já se mostrava ciente dos problemas e dificuldades estruturais que poderiam obstar o processo de desenvolvimento por meio da industrialização, ressaltando a importância estratégica do Estado para a superação desses obstáculos, nos anos 1970, quando já se podia perceber alguns resultados da industrialização ocorrida, ele aprofunda e ressalta o estudo da dimensão desses obstáculos, enfatizando a importância de medidas que foram negligenciadas ao longo do processo de industrialização, como políticas de distribuição de renda, integração da estrutura produtiva nacional e incentivo à inovação tecnológica.

Cabe ressaltar ainda o significado da crescente presença das empresas multinacionais ao longo dos anos 1950 e 1960que, segundo Furtado, modificou profundamente o caráter da industrialização brasileira.Neste ponto torna-se útil recorrer à periodização do processo de industrialização realizada por Tavares (1975), que o divide em três momentos, cada um caracterizado por um padrão de acumulação 
industrial específico: o de 1889 à crise dos anos 1930, de expansão industrial impulsionada pelo dinamismo e poder multiplicador do complexo cafeeiro; o de 1933 a 1956,de "Industrialização Restringida" ou "por Substituição de Importações"; e o de 1956 em diante, de "Industrialização Dependente ou Associada".

$\mathrm{Na}$ visão da autora, o único período que permite a sua classificação como de “substituição de importações" foi o período de 1933 a 1956, quando o crescimento industrial foi estimulado pela redução da capacidade de importar:por isso sua denominação alternativa desse período como um de "Industrialização Restringida" (TAVARES, 1975, p. 115-120).Segundo a autora, foi nesse período que o "comandante" da acumulação nacional de capital passou a ser o processo de expansão industrial (substituindo o anterior, que era o complexo cafeeiro), permitindo a instalação de uma indústria de bens de consumo leves, apesar de não ter sido suficiente para constituir forças produtivas capazes de sustentar a acumulação de capital necessária ao estabelecimento da indústria pesada de bens de produção.

Nesse sentido, parecer existir algum paralelismo com a avaliação de Furtado sobre o potencial do mercado interno para impulsionar a industrialização nos momentos de estrangulamento externo, na medida em que, para Tavares (1975, p. 120-121), o grande destaque desse período de industrialização restringida não foi o seu caráter substitutivo em decorrência do estrangulamento externo, mas sim a orientação endógena da acumulação de capital promovida pela própria expansão urbano industrial.

Em sua avaliação desse período de industrialização, Furtado (1974) também pondera que a verdadeira causa dos seus limites não foi a "exaustão do processo de substituição de importações", ou a "pequenez dos mercados nacionais", mas sim a “incompatibilidade entre o projeto de desenvolvimento dos grupos dirigentes, que visavam a reproduzir dinamicamente os padrões de consumo dos países cêntricos e o grau de acumulação de capital alcançado pelo país" (p. 91). Devido a esse caráter "imitativo" do processo industrial e à sua tendência à concentração de renda, sem promover inovações nem um processo autossustentado de acumulação de capital, a dependência do setor externo manteve-se, especialmente no fornecimento de capitais, equipamentos e insumos industriais.

Em seu texto de síntese Introdução ao Desenvolvimento: Enfoque HistóricoEstrutural (2000), o autor identifica a incorporação das economias periféricas na divisão internacional de trabalho como "um processo duplo e dessimétrico de transformação" (FURTADO, 2000, p. 95), dado por dois eixos atuantes em sentidos inversos e 
intensidades diferentes conforme o contexto histórico: a realocação dos recursos para a especialização em exportáveis (simplificação da estrutura produtiva), predominante até os anos 1930; e a modernização da demanda interna (diversificação da estrutura produtiva), de peso e importância crescente após a Grande Depressão. Em comum, esses dois eixos conformaram relações específicas de dependência do estrangeiro, seja como consumidores das exportações brasileiras, seja como fornecedores de padrões de consumo, tecnologias e insumos industriais.

Portanto,Furtado conclui que, no período de estrangulamento externo entre a Grande Depressão e as duas Guerras Mundiais,a transformação da estrutura produtiva brasileira em direção à industrialização foi na realidade um processo de adaptação às necessidades de uma demanda preexistente, induzida pelo exterior e impedida de se satisfazer via importações: "Não é a evolução do sistema produtivo que conforma e molda a demanda final, é esta última que comanda o processo de transformação" (2000, p. 110). Como mera adaptação, essa industrialização não foi capaz de romper a dependência dos centros externos, permanecendo carente de uma estrutura produtiva verticalizada (indústrias de base e equipamentos) e da capacidade de promover inovações tecnológicas.

Analogamente, na visão de Tavares (1975), após superada a crise da economia mundial, algumas economias subdesenvolvidas haviam sido capazes de diversificar sua estrutura econômica com a instalação de alguns setores industriais e de sustentar um processo de acumulação de capital endógeno. Porém, ficaram limitadas à indústria de bens de consumo leves, carentes das tecnologias necessárias para instalar a indústria pesada e, principalmente, de uma acumulação de capital suficiente para a escala de investimentos necessária ao avanço da indústria pesada, determinando a continuidade de sua dependência do centro da economia-mundo capitalista.

Neste contexto,Furtado(1974, p. 23-28) chama a atenção para o crescente predomínio da grande empresa transnacional nas relações produtivas e comerciais internacionais, e o seu significado para a industrialização ocorrida entre os anos 1950 e 1960 no Brasil. Segundo o autor, já após a Primeira Guerra Mundial podia-se perceber uma alteração no "caráter do capitalismo industrial" simultâneo ao processo de consolidação dos sistemas nacionais, em que cada burguesia proprietária e seu Estado se uniram em alianças em prol de "projetos nacionais", formando para isso suas próprias grandes empresas controladoras de mercados. Assim, se na fase do capitalismo britânico as decisões econômicas eram concentradas nos sistemas nacionais, após a Segunda 
Guerra estas passaram a ser centradas nas grandes empresas transnacionais, em uma nova lógica internacional de produção, comércio e acumulação de capital.

Estas constatações encontram paralelo com as formulações de Arrighi (1994) acerca da evolução histórica do que ele definiu como "ciclo sistêmico de acumulação norte-americano". Segundo o autor, este ciclo teria se iniciado no final do século XIX, inovando ao internalizar os custos de transação (o ciclo anterior, britânico, inovara pela internalização dos custos de produção) por meio da integração vertical empresarial, que facilitou a gestão e reduziu os custos de transação de insumos e etapas intermediárias da produção.Além disso, essa nova lógica empresarial permitiu acelerar o tempo de produção e controlar riscos, conferindo vantagens competitivas decisivas que permitiram a esse novo tipo de empresa conquistar rapidamente os mercados domésticos norte-americanos e se expandir transnacionalmente pelo mundo. Por fim, as necessidades de expansão das empresas norte-americanas tiveram ainda o apoio decisivo de Washington ${ }^{50}$, de tal sorte que os anos 1950 e 1960 foram de forte difusão mundial de suas atividades "transnacionais", com aumento da produção e dos fluxos de comércio e investimentos internacionais (ARRIGHI, 1994, p. 247-250).

Para Furtado(2000, p. 120), a rápida difusão desse “capitalismo das transnacionais” após a Segunda Guerra implicou,para o Brasil, no início de uma fase de rápida industrialização controlada por essas grandes empresas, alterando fundamentalmente o perfil da industrialização brasileira. Com suas importantes vantagens competitivas, estas empresas facilmente conquistaram posições nas economias subdesenvolvidas, que além de dependentes da tecnologia e dos insumos e equipamentos importados, subutilizavam a capacidade produtiva e tinham deseconomias de escala. Para o autor, iniciou-se então um processo de desnacionalização da indústria brasileira, com crescente participação do capital estrangeiro em setores estratégicos da economia nacional.

De fato, houve uma grande transformação estrutural do parque industrial brasileiro, iniciando o período chamado por Tavares (1975, p. 127-32) de "industrialização dependente ou associada" ${ }^{51}$. No entanto, a autora pondera que, em um

\footnotetext{
${ }^{50}$ Cabe ressaltar que esse período de dinamismo econômico pós-Segunda Guerra foi beneficiado ainda pela intensa política militar dos Estados Unidos, que com seus gastos bélicos e assistência prestada aos seus aliados, forneceu abundante liquidez para a economia mundial (ARRIGHI, 1994, p. 305-308).

${ }^{51}$ Para a autora, esse período não pode ser caracterizado como de "substituição de importações", ainda que o coeficiente de importações tenha caído com a entrada em operação do novo parque industrial, devido ao montante das importações decorrentes do processo de industrialização, em um contexto de ausência de estrangulamento externo (TAVARES, 1975, p. 133).
} 
primeiro momento, a "associação subordinada" ao capital estrangeiro não prejudicou a taxa de acumulação do capital nacional, nem a tendência a favor do capital estrangeiro e das estatais prejudicou o capital privado nacional. Para ela, houve uma associação de interesses, uma vez que a transformação só foi possível pelo interesse previamente existente do Estado brasileiro em fazer avançar a indústria pesada, que ficara obstada pela necessidade de investimentos maciços. Como a capacidade produtiva tinha que ser criada muito à frente da demanda, era necessária uma estrutura de financiamento e risco com grande capacidade de mobilização e centralização de capitais a qual o Estado brasileiro não possuía.O acesso ao capital estrangeiro por meio das transnacionais veio a suprir a as necessidades de capital e tecnologia para o projeto de industrialização, enquanto o Estado acionava "a máquina de crescimento privado nacional", atuando nos setores não acessíveis ao capital privado nacional (como o de bens pesados de produção) e na facilitação das operações de financiamento da indústria (TAVARES, 1975, p. 135-140).

Conforme Evans (1980, p. 45-50), por meio desta associação,o capital nacional manteve algum grau de influência nas negociações com o Estado e o capital estrangeiro, apesar de não deter posição hegemônica nem econômica nem política, retendo os nichos de difícil penetração às empresas multinacionais.Na leitura de Tavares (1975, p. 143164), o crescimento econômico garantiu no início desta fase um "lugar para todos" no processo de acumulação de capital, permitindo a expansão do capital nacional privado ao lado do Estado e do capital estrangeiro. Porém, quando o ciclo desacelerou, a tendência foi à consolidação de um caráter oligopolista, com a falência das empresas menores e a concentração de mercados em algumas grandes empresas com capacidade para se modernizar e adaptar à situação desfavorável. Nesses períodos, as empresas multinacionais foram beneficiadas pela sua maior capacidade de promover diferenciações de produtos e integrações verticais, além de suas economias de escala, levando à desnacionalização de alguns setores tradicionais da indústria brasileira, como a farmacêutica e a alimentícia.

Furtado (2000, p. 122) ressalta ainda que as transnacionais expandiram de tal modo suas atividades que lograram transformar algumas poucas economias periféricas em plataformas de exportação de manufaturados, permitindo uma nova inserção dessa parte da periferia na divisão internacional do trabalho. No entanto, o autor avalia que, no Brasil, isto ocorreu sem absorver as grandes massas de trabalhadores da periferia ao importar tecnologias inadequadas para sua estrutura socioeconômica, resultando em 
uma urbanização desigual e caracterizada pelo subemprego e marginalização crescente $^{52}$. Logo, intensificou-se a heterogeneidade tecnológica, o diferencial de produtividade entre setores e regiões, a desigualdade de renda, a marginalização e o subemprego urbano.Para o autor, portanto, a nova inserção internacional da economia brasileira expressou uma redefinição dos canais de dependência sem incrementar o seu grau de autonomia ou controle sobre o seu desenvolvimento, resultando em uma indústria nacional ainda mais controlada e dependente do centro.

Conforme sumariza Bresser (1977, p. 203-204), a persistência da situação de subdesenvolvimento manifestou-se por diversos elementos, a iniciar pelo ganho de espaço considerável das empresas multinacionais em diversos segmentos industriais, substituindo a tradicional dependência do comércio exterior por uma dependência das tecnologias e inovações desenvolvidas no centro do sistema. Além disso, apesar do aumento das taxas de crescimento e de acumulação de capital, não houve distribuição de renda nem efetiva integração econômica nacional, mas sim o aumento da concentração de renda e das desigualdades regionais. Em suas próprias palavras:

As potencialidades do modelo de ISI haviam sido consideradas esgotadas aproximadamente no inicio dos anos 60. Este novo estilo de desenvolvimento, dependente das empresas multinacionais, aberto para o comércio exterior a fim de aproveitar os recursos naturais abundantes e a mão de obra barata existente nos países periféricos, orientado internamente para a produção de bens de consumo de luxo para consumo de uma minoria privilegiada, foi a nova forma pela qual os países subdesenvolvidos se inseriram no sistema capitalista central, em expansão, da segunda metade deste século. [...] este novo modelo industrializava os países, mas não resolvia seus principais problemas. Aumentava o grau de dependência, concentrava a renda, marginalizava radicalmente grande parte da população. (BRESSER, 1977, p. 205)

Por fim, a visão de Rangel (1957) compõe uma interpretação bastante original e alternativa às de Prado Jr. e Furtado. Por meio da sua "lei da dualidade básica da economia brasileira", o autor realiza uma avaliação positiva do processo de industrialização, identificando a criação de um centro de dinamismo endógeno à economia brasileira e o seu sucesso relativo na conquista de maior independência dos centros da economia-mundo capitalista - sem negar, no entanto, que este processo

\footnotetext{
${ }^{52}$ Furtado aponta que esse "processo de marginalização urbana" foi muito estudado por sociólogos latinoamericanos, tendo em vista que grande parte da população dos países periféricos fícou relegada a subsistemas culturais e informais urbanos, constituindo imensos reservatórios de mão de obra subutilizados. "A inadequação da tecnologia [...] de um ângulo de vista sociológico traduziu-se na polaridade modernização-marginalidade" (FURTADO, 2000, p. 29).
} 
esteve alicerçado na expansão da desigualdade e que se manteve fundamentalmente subordinado às lógicas do centro do sistema.

Conforme o autor, as "relações externas de produção" sempre tiveram um importante papel na nossa economia, de tal sorte que "nossa história acompanha pari passu a história do capitalismo mundial [...] O mercantilismo nos descobriu, o industrialismo nos deu independência e o capitalismo financeiro, a república" (RANGEL, 1957, p. 302).Em sua visão, a economia brasileira sempre foi profundamente afetada pelas oscilações dos centros da economia-mundo capitalista, tendo permanecido uma economia dependente ao longo das sucessivas substituições desse centro:

Embora o Brasil não faça parte do chamado centro dinâmico da economia mundial, isto é, aquela área em que se engendram as flutuações econômicas estudadas como ciclos longos ou ciclos de Kondratiev $^{53}$, visto como se insere conspicuamente na periferia da mesma economia mundial, tem-se mostrado muito sensível a esses movimentos. [...] o dito centro muda a cada novo ciclo, ao passo que o Brasil tem ocupado posição simétrica, em relação ao centro, qualquer que seja este. (RANGEL, 1985, p. 690).

Apesar dessa fragilidade externa da economia brasileira- um traço que Rangel compartilha com os demais autores -, o autor pondera que existe uma permanente disputa entre as relações externas de produção e as relações internas, constatando uma evolução mais rápida das últimas do que das primeiras. Para o autor, isso "significa estarmos queimando etapas" (RANGEL, 1957, p. 302) em relação à história econômica europeia, um fenômeno possível tendo em vista que a transformação de uma estrutura produtiva resulta do desenvolvimento de suas forças produtivas, que pode se dar em diferentes tempos. E assim, Rangel propõe um corolário da dualidade econômica brasileira: "que o aspecto interno e o externo podem envelhecer em momentos diferentes ou, noutros termos, que a substituição de uma estrutura por outra não se processará obrigatoriamente no campo interno e no externo ao mesmo tempo" (RANGEL, 1957, p. 304).

Nesse sentido, Rangel aponta que o Brasil, no geral, reagiu ativamente aos ciclos de Kondratiev da economia-mundo capitalista, aprofundando seus laços externos nas

\footnotetext{
${ }^{53}$ Nikolai Dmitriyevich Kondratiev (1892-1938) foi um economista russo que tentou provar estatisticamente a evolução cíclica da economia capitalista. Apesar de ensaiar um esboço de suas ideias no seu livro "On the Notion of Economic Statics, Dynamics and Fluctuations" (1924), sua teoria dos ciclos econômicos só tornou-se internacionalmente conhecida em 1925, com a publicação de "The Major Economic Cycles". Nos anos 1930, suas ideias foram aproveitadas por Joseph Schumpeter, que nomeou os ciclos como "Ondas de Kondratiev". Seus "ciclos" ou "ondas longas" duram entre 40 a 60 anos, apresentando duas fases: a fase A ascendente e a fase B descendente.
} 
fases expansivas (fases A), aumentando exportações e importações, e distanciando-se nas fases recessivas (fases B), voltando-se "para dentro", reduzindo exportações e importações por meio de ajustes estruturais e da reorganização de suas estruturas produtivas.Por exemplo, ao se iniciar a fase B do primeiro ciclo europeu (1815-1848), o estrangulamento externo levou à busca da diversificação produtiva nas fazendas de escravos para autoconsumo. Com o início do segundo Kondratiev (predomínio do capitalismo industrial inglês e Proclamação da Independência) e a passagem a uma nova fase A, essa tendência foi invertida pela ampliação dos mercados consumidores de exportações brasileiras, voltando o foco no comércio exterior. Adicionalmente, com a Abolição e a República, as "fazendas escravocratas" foram substituídas por "latifúndios monocultores" que, com o capital liberado pelo fim da escravidão, tinham recursos para investimentos de outra natureza. Assim, a passagem da escravidão para o latifúndio teria permitido o desenvolvimento de forças produtivas (especialização monocultora); a ampliação do mercado interno (assalariamento); e a eliminação dos "falsos custos" imobilizados nos escravos.

Em consequência, na fase B desse segundo ciclo (1873-1896), iniciou-se um esforço de substituição de importações que desta vez não se concentrou na casa-grande, mas nas cidades, tendo como empresários não os senhores de escravos, mas o capital mercantil nacional ${ }^{54}$. Quando o comércio exterior voltou a crescer na fase A do terceiro ciclo (1896-1921), este foi logo interrompido por duas Guerras Mundiais e uma depressão mundial, iniciando a fase B (1921-1948), de tal modo que "o esforço mercantil de substituição de importações desbordou seus quadros primitivos [...] a substituição de importações ia assumindo feição industrial [...]. Tinha começado a industrialização do Brasil” (RANGEL, 1985, p. 691).

Em sua interpretação, o impulso industrializante foi tamanho que o Brasil surgiu após a Segunda Guerra Mundial como uma das economias mais dinâmicas do mundo capitalista, autopropulsionando um mercado interno capaz de se manter mesmo com a expansão do comércio exterior e avançando até mesmo sobre o setor agrominerador. Assim, o autor sumariza que na fase B do primeiro Kondratiev houve a diversificação das unidades produtivas básicas; no segundo, houve o aumento da produção artesanal e das manufaturas pré-industriais; no terceiro, substituiu-se parte das unidades pré-

${ }^{54}$ Rangel aponta que o agente central no primeiro ciclo era o capital mercantil português, que fazia a ponte entre a economia escravista colonial interna e a economia capitalista (mercantil) externa. Este foi substituído pelo capital mercantil nacional no segundo ciclo, permitindo um importante desenvolvimento do mercado interno brasileiro. 
industriais por unidades industriais. Ao contrário das visões de Prado Jr. e Furtado, para Rangel (1985, p.698-699) o autor a industrialização ocorrida no terceiro ciclo não só foi apoiada pela demanda interna em expansão impulsionada pelo assalariamento, mas também pela existência de uma acumulação de capital considerável nas mãos de grupos nacionais dispostos a aplicá-la no processo produtivo (o "capital mercantil nacional") ${ }^{55}$.

$\mathrm{Na}$ realidade, esta interpretação remonta a uma identificação anteriormente feita por Rangel (1955, p. 147-148), à semelhança da que Furtado já fizera, da existência de três estratos no complexo da economia brasileira: a "economia natural pré-capitalista de autoconsumo" (setores de subsistência), que concentra boa parte da força de trabalho; a "economia de mercado capitalista" (indústria, serviços e agricultura de exportação), que ocupa pequena parte do total de mão de obra nacional, mas é a parte mais dinâmica da economia; e a "economia externa" (comércio exterior e capitais estrangeiros). Segundo o autor, enquanto a "economia pré-capitalista" tendeu a se dissolver e transferir seus fatores de produção para a capitalista, a "economia capitalista" por sua vez tendeu a gerar pressões sobre a "economia externa" até então dominante, e a substituí-la por meio do processo de industrialização.

De sua parte,Furtado (1965, p. 181)aventou a transformação da economia brasileira em decorrência do processo de industrialização sobre controle do Estado de modo a formar três estratos:o setor de subsistência, o setor exportador ligado ao comércio exterior, e o mercado interno e suas indústrias.Nessa sua análise "pré-mito", o mercado interno e a industrialização, com a ação coordenada pelo Estado, teriam o potencial para promover as transformações estruturais necessárias para superar a condição de subdesenvolvimento.

É importante ressaltar que, tanto Rangel quanto Furtado se utilizaram de universos conceituais próprios, mas potencialmente convergentes ao de Braudel, para identificar na estrutura produtiva brasileira "setores econômicos" cuja dinâmica integrada e contraditória poderia conferir potencial de dinamismo econômico e acumulação de capital.

\footnotetext{
55 Enquanto Prado Jr. e Furtado enfatizam a industrialização inicial por bens de consumo leves como orientada pela demanda preexistente de bens de consumo importados, Rangel (1985, p. 692-693), pelo contrário, explica essa fase inicial da indústria com base nas condições dos fatores de produção préexistentes. Ele aponta que a crise do setor exportador acarretou na expulsão de uma grande massa de trabalhadores, liberando mão de obra para o processo industrial, que apesar de intensivo em capital e poupador de trabalho, foi favorecido pelo uso de instalações e equipamentos construídos artesanalmente com muito trabalho e pouco capital.
} 
No caso dos estratos de Rangel, a "economia de mercado interna" é identificada como a porção mais dinâmica, tendente a absorver os outros dois estratos e angariar o apoio do Estado no seu processo de expansão. A partir de um determinado estágio do processo de industrialização, a escala e complexidade dos elementos necessários ao seu avanço exigiram a crescente ação do Estado como promotor do progresso industrial por meio de investimentos e do controle do comércio exterior e do mercado de divisas, conduzindo a economia brasileira a outro patamar, com o desenvolvimento de uma "economia capitalista monopolista" estatal, à semelhança das alianças entre o poder econômico e o poder político destacadas por Braudel, Wallerstein e Arrighi.

Nesse sentido, apesar de conceder que a acumulação de capital permaneceu sendo essencialmente controlada do exterior, Rangel (1985) avalia que o progresso da industrialização, especialmente a partir do terceiro ciclo longo, permitiu um extraordinário crescimento da "economia de mercado capitalista brasileira", significando o surgimento de um novo centro de dinamismo interno, "capaz de engendrar ciclos diferentes e independentes dos ciclos longos que tinham sua origem no centro dinâmico da economia mundial” (p. 691). Isto é, a economia brasileira adquiriu maior capacidade e autonomia para "descolar-se" das oscilações mundiais, reduzindo sua vulnerabilidade e dependência externa.

Segundo o autor, esses ciclos corresponderiam aos ciclos de Juglar ${ }^{56}$ que, orientados pelo processo de industrialização brasileiro, avançaram conforme uma substituição de importações escalonada, setor após setor industrial (cada ciclo correspondendo a um setor). Apesar de o Brasil continuar periférico, sensível às mudanças do centro dinâmico externo e dependente de suas tecnologias, esta nova capacidade de gerar endogenamente um ciclo nacional próprio conferiu nova dimensão ao capitalismo brasileiro, de tal modo que os ciclos breves ora agravariam os ciclos longos, ora os amenizariam ${ }^{57}$. (RANGEL, 1985, p. 692-693)

No entanto,o autor enfatiza que esse processo em direção à constituição de uma economia menos sujeita às oscilações da economia-mundo capitalista não se deu de modo automático. Na realidade, cada fase recessiva dos ciclos longos significou a necessidade de transferir recursos dos setores em crise e com excesso de capacidade

\footnotetext{
${ }^{56}$ Clément Juglar (1819-1905) foi um economista francês que tentou identificar estatisticamente os ciclos industriais, chegando a ciclos de duração entre 7 a 11 anos, com quatro fases: prosperidade, crise, liquidação e recessão.Uma de suas principais obras é "Des Crises Commerciales et de leur retour périodique en France, na Angleterre et aux États-Unis" (Paris: Guillaumin, 1862).

${ }^{57}$ Por exemplo, a industrialização brasileira (e o primeiro ciclo breve brasileiro), iniciou-se na fase B do terceiro ciclo longo de contração de nossas exportações, amenizando os efeitos da crise externa.
} 
para aqueles em ascensão, de modo a renovar gradualmente o sistema econômico nacional em direção ao padrão tecnológico industrial. Essa realocação de recursos entre setores dependeu da existência de condições jurídico-institucionais específicas, especialmente instrumentos adequados de intermediação financeira. $\mathrm{Na}$ ausência destas, Rangel (1985, p. 700) aponta que caberia ao Estado realizar esse papel, orientando o esforço de industrialização para certas áreas e desviando-o de outras, e muitas vezes submetendo as finanças públicas à forte pressão e crise. Assim, o autor defende a substituição progressiva do "capital mercantil nacional" pelo Estado como personagem central da intermediação entre as relações econômicas "interiores" e "exteriores" brasileiras, delineando uma política de crescente intervenção estatal.

Por exemplo, durante a fase B do terceiro ciclo longo mundial, o progresso da industrialização brasileira viu-se condicionado pelo "câmbio cadente", que simultaneamente estimulava o desenvolvimento industrial e limitava a sua continuação devido ao encarecimento dos equipamentos e insumos importados. Para garantir essas importações, o Estado deveria promover uma crescente intervenção no mercado cambial, assumindo o papel de um "Estado comerciante", controlador do mercado de divisas:

O Brasil modifica suas relações externas de produção [...] Cria um aparelho destinado a tornar viáveis as suas relações com os demais países, habilitando-se a conquistar uma posição mais cômoda. A essência dessa reforma revolucionaria é a emergência do Estado como comerciante, condição indispensável para que o capitalismo se consolide e se reforce no interior, na indústria como na agricultura. (RANGEL, 1957, p. 353).

Isso significou a transformação do "terceiro estrato" da economia brasileira, de simples "economia exterior" em "economia capitalista monopolista", quase um "capitalismo de Estado", que dominaria e controlaria o comércio exterior.Assim, Rangel (1955, p. 152)entende que o "terceiro estrato" passaria a estimular a atividade do "segundo estrato", de tal modo que o processo de desenvolvimento brasileiro passaria a resultar desse estímulo do terceiro estrato sobre o segundo, e deste sobre o primeiro. Os três estratos hierárquicos da economia brasileira passariam a ser, em consequência, a "economia natural pré-capitalista de autoconsumo", a "economia de mercado capitalista" e a "economia exterior" transformada em "economia capitalista monopolista".

Como exemplos, Rangel (1985, p. 707-712) destaca duas novidades institucionais desenvolvidas pelo Estado que foram cruciais para impulsionar o início de 
dois ciclos endógenos da economia brasileira: a Instrução 70 da SUMOC de $1953^{58}$, que teria impulsionado o Plano de Metas de Juscelino Kubistchek, iniciando a instalação da indústria de bens de consumo duráveis; e a correção monetária de meados dos anos $1960^{59}$, que teria instigado o "milagre" de 1967-1973, quando começou a instalação da indústria pesada (siderurgia, petroquímica, construção naval, hidrelétricas, entre outras).

Ou seja, para Rangel o mercado interno e o setor industrial seriam capazes, com a coordenação e planejamento do Estado, de fomentar o "capitalismo nacional" e endogeneizar mecanismos de acumulação de capital continuada. Esse diagnóstico otimista contrasta com a visão de Furtado em sua fase de revisão dos resultados negativos do processo de industrialização, que apesar de conceder as importantes transformações promovidas na estrutura brasileira, destaca a inadequação dessas reestruturações às realidades socioeconômicas do país, agravando a heterogeneidade social e a desintegração regional, e mantendo os centros externos de decisão do processo de acumulação de capital.

Assim, quando em 1973 a primeira crise do petróleo marcou o início da fase B do quarto ciclo longo, o Brasil ainda estava na fase A do seu ciclo breve, que durou até os anos 1980. Em consequência, houve um descolamento da economia brasileira das circunstâncias mundiais nos anos 1970, em que a indústria pesada se expandiu fortemente ${ }^{60}$, transformando-se em um setor industrial moderno e aumentando a oferta de bens de capital na economia.Somente na virada para os anos 1980, quando as fases B do ciclo longo mundial e do ciclo breve brasileiro coincidiram, o autor identifica o início da crise que desmantelou o regime militar.

Portanto, para Rangel (1955, p. 146) o "motor primário" do desenvolvimento brasileiro foi durante muito tempo condicionado por fatores exógenos, que

\footnotetext{
${ }^{58}$ Muito resumidamente, essa instrução instituiu um regime de taxas múltiplas de câmbio, mantendo o câmbio favorável para as importações dos bens considerados essenciais à industrialização.

${ }^{59}$ A correção monetária foi, conforme Rangel, uma reação à perda de valor das hipotecas e empréstimos pela existência da inflação, significando que os instrumentos financeiros recuperavam sua função e a taxa real de juros pôde ser reduzida. E assim, "o Brasil viu surgir um sistema nacional de poupança... Os investimentos cobertos com fundos privados entraram a elevar-se, notadamente na construção residencial, liberando fundos para outras aplicações. Estava criada a escola maternal do capitalismo financeiro brasileiro" (RANGEL, 1985, p. 710).

${ }^{60} \mathrm{E}$ importante ressalvar que tal ocorreu por meio de um crescente endividamento externo, usado para financiar a instalação da indústria pesada e as importações dos insumos e equipamentos necessários. A crise mundial provocara a queda das exportações em paralelo, conforme Arrighi (1990), a uma grande "revolução financeira global" decorrente do expressivo crescimento do mercado de eurodólares (lucros de multinacionais norte-americanas depositados na Europa, fora do controle de Washington) e da substituição do sistema de paridades cambiais com o dólar por um de taxas cambiais flexíveis, resultando em uma abundante oferta de liquidez internacional caracterizada por perigosos fluxos especulativos e de alto risco que inundaram o mundo em busca de oportunidades de investimentos.
} 
impulsionaram o investimento nas fases recessivas dos ciclos longos mundiais, levando nossa economia a se reestruturar. Ou seja, a variável estratégica era o comércio exterior. Isto até os anos 1930, quando começa o processo de industrialização que, apoiado no mercado interno e no capital nacional, foi capaz de aos poucos engendrar os nossos próprios ciclos econômicos e pôr em marcha um mecanismo de sucessivas substituições de importações. No entanto, o avanço desse processo permaneceu condicionado por fatores externos, como o fornecimento de tecnologias, equipamentos e insumos industriais - que, ressalta o autor, são elementos que podiam ser controlados por meio do planejamento estatal no comércio exterior, no mercado de divisas e nos investimentos públicos. (RANGEL, 1955, p. 170)

De qualquer modo, Rangel mostra que, apesar da manutenção da condição dependente da economia brasileira, o país foi capaz de empreender transformações qualitativas importantes em sua estrutura socioprodutiva e na dinâmica de acumulação interna, de modo a redefinir o seus elos de vinculação à economia-mundo capitalista e assumir novos papéis na divisão internacional de trabalho. Principalmente, o autor avalia que o país foi capaz de criar seus próprios centros de dinamismo interno, empreendendo seus próprios ciclos de acumulação de modo a moderar os ciclos maiores da economia-mundo capitalista, definindo uma trajetória não totalmente subordinada às oscilações do sistema. Tendo em vista essa capacidade demonstrada, Rangel acredita no potencial da economia brasileira de modificar sua condição dependente e assumir o controle de uma acumulação de capital crescente e endogenamente sustentada, enfatizando para isso a importância da ação estratégica do Estado na economia.

Nesse sentido, é interessante realizar um confronto entre o diagnóstico de Rangel e a leitura dessas transformações feita por Evans (1980), que levou à suas formulações sobre o que ele chamou de "desenvolvimento dependente" e a "falsa dicotomia centro-periferia" (p. 10). Retomando a "teoria do imperialismo" associada à análise da dependência, Evans (1980) analisa como as relações de dependência do Brasil foram modificadas pela dinâmica pós-Segunda Guerra, em que os interesses do Estado brasileiro e da burguesia industrial nacional se articularam aos das grandes empresas multinacionais em prol do processo de industrialização, determinando um novo papel para o país dentro da economia-mundo capitalista.

$\mathrm{Na}$ interpretação do autor, o resultado desta "tríplice aliança" foi um "desenvolvimento dependente ou associado", com a diversificação da capacidade industrial e a redefinição do papel da economia brasileira na economia-mundo 
capitalista. Neste novo papel, o país tanto trabalhou para o equilíbrio do sistema - na medida em que o país passou a fazer parte das redes de produção e comércio contraladas pelas empresas multinacionais -,quanto simultaneamente representou a sua revolução a partir da periferia -tendo em vista que o foco passou da tradicional exportação de primários à de manufaturados, saindo da periferia para compor uma nova semiperiferia. (EVANS, 1980, p. 11-25).

A partir de então, “tornou-se impossível um exame dos países do Terceiro Mundo simplesmente como 'a periferia'" (EVANS, 1980, p. 25). Cabe ressalvar que o autor concede que, apesar de o Brasil ter sido "incorporado à economia capitalista mundial de uma nova maneira" (EVANS, 1980, p. 26), o país não deixou de ser dependente, mas manteve muitas das contradições típicas da "dependência clássica", em que o setor externo continua tendo influência decisiva e as massas foram excluídas do processo de desenvolvimento. Entretanto, sua estrutura socioprodutiva se transformou, permitindo um caso especial de dependência, com abertura para uma acumulação interna de capital e a industrialização da economia.

Logo, parece haver concordância com a visão de Rangel (1955) no que diz respeito à transformação qualitativa da economia brasileira e o seu reposicionamento dentro da hierarquia da economia-mundo capitalista, apesar de manter-se fundamentalmente dependente do setor externo. Além disso, a aposta de Rangel (1955) na centralidade do papel estratégico do Estado para a transformação da economia brasileira também é endossada por Evans (1980), que identifica no Estado o agente em posição de defender a acumulação de capital local e a efetiva industrialização do país. Para o autor, enquanto a "burguesia nacional industrial" não exercia o domínio político nem o econômico, a atuação local do capital estrangeiro era vinculada aos interesses da acumulação de capital no exterior, o que exigiu uma "centralidade do Estado empresarial para o desenvolvimento dependente" (EVANS, 1980, p. 50). Em síntese, o aparelho estatal articularia os interesses do capital nacional e do estrangeiro na tentativa de garantir o projeto de industrialização brasileira, ainda que isso se desse de modo diferente em cada setor econômico. 


\subsection{SÍNTESE: TRÊS INTERPRETAÇÕES SOBRE A INDUSTRIALIZAÇÃO BRASILEIRA}

Apesar de cada um desses autores desenvolver uma visão própria sobre a inserção internacional do país na economia-mundo capitalista, de certo modo todos eles concordam que a dinâmica externa sempre foi fundamental na determinação dos rumos da economia nacional. No entanto, no que diz respeito à capacidade brasileira de atenuar e moderar o elemento externo, parece existir uma gradação que remonta às avaliações de cada autor sobre a envergadura estrutural do país para sustentar núcleos de dinamismo econômico interno e sobre as transformações impulsionadas pelo processo de industrialização.Seja ressaltando a permanência das relações de dependência e a debilidade do mercado interno (Prado Jr.), ou reconhecendo um "subdesenvolvimento industrializado" com diversificação produtiva associada à manutenção ou agravamento dos elementos de subdesenvolvimento (Furtado), ou ainda enfatizando a promoção de uma mudança qualitativa da inserção externa de nossa economia (Rangel).

Apesar de os três identificam um "condicionamento" do processo histórico brasileiro por forças exógenas desde a colônia, este é abordado por cada um com um olhar próprio e específico, imprimindo a sua marca e interpretação particular. Assim, para Prado Jr. a evolução da economia brasileira sempre foi determinada e dependente dos centros estrangeiros da economia mundial, e permaneceu desse modo até sua estrutura contemporânea devido à sua incapacidade para dinamizar endogenamente seu próprio desenvolvimento.Tendo se formado para atender aos mercados externos, a economia brasileira teria consolidado uma estrutura socioprodutiva inadequada e desvinculada das necessidades da maioria da população, impedindo a formação de um mercado consumidor capaz de sustentar um processo de acumulação dinamicamente endógeno.

Mesmo após o início de um "processo de desenvolvimento moderno" no século XVIII (PRADO JR., 1989, p. 54), com a disseminação do trabalho livre assalariado, a formação de um mercado consumidor interno e o avanço da industrialização, o autor avalia que tal transformação só foi possível pela ação de impulsos exógenos decorrentes do imperialismo britânico e do sucesso do café nos mercados internacionais, tendo o 
país mantido sua posição periférica de exportador de primários e dependente da economia mundial.

Já com outra visão interpretativa, Furtado estabelece essa mesma relação dependente da economia brasileira perante a economia mundial, porém explicada a partir dos processos de subdesenvolvimento e desenvolvimento que introduz em seus escritos dos anos 1960. Ao definir o subdesenvolvimento como resultado da sua incorporação à divisão internacional de trabalho decorrente da Revolução Industrial europeia do século XVIII como fornecedor de primários e consumidor de manufaturados europeus, e analisar as consequências dessa dinâmica centro-periferia, especialmente em momentos de estrangulamento externo, Furtado acreditava no potencial da industrialização de promover importantes transformações estruturais e superar o estado de subdesenvolvimento, aliada à ação estratégica do Estado no seu planejamento e condução. Porém, nos anos 1970, ao avaliar os resultados da industrialização já ocorrida, o autor a percebe como um processo orientado pelos interesses de uma elite dominante vinculada a forças exógenas (a busca pela "modernização" ou "dependência cultural") que intensificou a heterogeneidade socioeconômica nacional e a sua dependência de capitais, tecnologias e insumos importados. Ou seja, apesar de reconhecera complexificação da estrutura socioprodutiva nacional, Furtado criticou o processo de industrialização ocorrido pela sua inadequação aos interesses da sociedade brasileira, incapaz de reduzir a dependência externa,endogeneizar o processo de desenvolvimento brasileiro e amenizar as desigualdades socioeconômicas e regionais do país.

Alternativamente, Rangel aponta que, se de um lado a economia brasileira se desenvolveu historicamente como "complemento" dos sucessivos centros da economia mundial, de outro lado suas "relações internas de produção" também foram decisivas, de tal modo que o Brasil no geral reagiu ativamente às oscilações da economia mundial (os ciclos longos), aprofundando seus laços nas fases expansivas (aumentando as relações comerciais) e distanciando-se nas fases recessivas, de modo a ajustar sua estrutura produtiva à conjuntura externa. Portanto, o país não foi passivo aos ditames da economia-mundo capitalista, mas reagiu de forma a empreender transformações importantes em seu arcabouço socioprodutivo, de modo a paulatinamente construir e fortalecer uma dinâmica de acumulação doméstica. Destarte, apesar de permanecer dependente e sujeito às turbulências externas, por meio dessas reestruturações, o país foi capaz de redefinir o seus elos de vinculação à economia-mundo capitalista e assumir 
novos papéis na divisão internacional de trabalho, alçando-se da periferia exportadora de primários à semiperiferia industrializada.

De certa forma, tais diferenças de interpretação, além de serem informadas pelas suas respectivas perspectivas teóricas, remetem aos diagnósticos próprios de cada autor sobre o processo de industrialização ocorrido no horizonte temporal deste trabalho. Para Prado Jr., devido à falta de correspondência entre a estrutura socioprodutiva brasileira e as necessidades gerais de sua população, o mercado interno não encontrou condições para se fortalecer, e a indústria nacional não teve fundamentos sólidos e adequados para dinamizar um processo de acumulação impulsionado por forças endógenas ao país. Isso porque a industrialização serviu essencialmente a uma demanda interna reduzida, de uma minoria abastada, sendo inicialmente favorecida pelos momentos de dificuldades para importar e posteriormente protegida por meio de tarifas, controles cambiais e outras políticas protecionistas. Isto é, em sua avaliação a indústria foi resguardada da concorrência externa, não tendo incentivo ao progresso técnico e à melhora qualitativa, mantendo-se dependente das tecnologias, máquinas e insumos industriais importados. Manteve-se assim, em sua avaliação, uma economia nacional dependente e com reduzido grau de autonomia externa.

Já o posicionamento de Furtado com relação à industrialização evolui em paralelo ao seu próprio processo de amadurecimento intelectual, na medida em que o autor vivenciou o desenvolvimento de uma programação industrial no pós-guerra e pôde avaliar os seus resultados nos anos 1970. Se de início Furtado acreditava no potencial de transformação estrutural da economia por meio da industrialização sob planejamento estatal, alguns anos depois o autor mostrou-se desiludido com os seus resultados, em especial diante da "falha" em trazer o desenvolvimento econômico. Ele avalia então a industrialização como um processo de imitação dos sistemas industriais das sociedades desenvolvidas, limitado por não pressupor uma dinâmica interna de acumulação nem o investimento no desenvolvimento de melhoras produtivas, mas focado apenas na "modernização" do consumo das elites dominantes. Isto é, uma industrialização que se formou para substituir importações das nossas elites em momentos de "estrangulamento externo",reproduzindo padrões de consumo estrangeiros.

Em seu texto de síntese dos anos 2000, Furtado reconhece a dinamização das economias periféricas que lograram formar um núcleo industrial interno, concedendo o mercado interno como um "fator dinâmico" dessa transformação, tendo em vista que somente as economias que reuniam certas condições (como o potencial do mercado 
interno) tiveram sucesso em avançar o processo de industrialização para enfrentar os momentos de restrição externa. Portanto, essas economias formaram estruturas subdesenvolvidas complexas, com núcleos de dinamismo capitalista internos e parques industriais importantes - apesar de manterem-se dependentes, porém em um novo tipo de dependência externa, agora essencialmente tecnológica, e da considerável penetração do capital estrangeiro em setores industriais estratégicos nacionais. Diferentemente de Prado Jr., para Furtado o processo de industrialização teve o mérito de elevar a complexidade da economia brasileira, porém acelerou alguns de seus elementos de subdesenvolvimento, como a heterogeneidade estrutural e a dependência dos capitais e tecnologias estrangeiros.

Em contraste, Rangel dá outro peso à industrialização como promotora do desenvolvimento e da redução da vulnerabilidade externa da economia brasileira. Em sua visão, o processo de industrialização constituiu um esforço de diversificação produtiva que implicou no desenvolvimento das forças produtivas e na ampliação do mercado interno, tendo envolvido a ação do capital mercantil nacional e a formação de um núcleo de dinamismo capitalista interno. Apesar de a industrialização ter avançado nas cadeias produtivas por meio de um processo de substituição de importações impulsionado pelas circunstâncias externas, ela foi aos poucos adquirindo vitalidade própria, ao ponto de ensejar um ciclo econômico nacional que foi aos poucos ganhando independência relativa sobre os ciclos econômicos mundiais na determinação dos rumos do desenvolvimento nacional.

Nesse sentido, pode-se aventar que Rangel anteviu o avanço do Brasil para uma condição semiperiférica, no sentido de semiperiferia trabalhado por Wallerstein (2000) e Arrighi (1994), ou seja, uma posição intermediária na hierarquia da economia-mundo capitalista: não pertencente mais à periferia, mas sem ter conseguido alçar-se a centro. Ainda vulnerável às oscilações do centro da economia-mundo capitalista e dependente de suas tecnologias e capitais, porém com um núcleo de dinamismo capitalista próprio, industrializado e capaz de gerar endogenamente seu próprio ciclo econômico, permitindo ao país moderar a influencia dos ciclos externos e adquiri um controle cada vez maior sobre os rumos de sua economia. Conforme visto, para Rangel essa nova condição da economia brasileira exprimiu-se já nos anos 1970, com o seu "descolamento" da economia-mundo capitalista atingida pelas crises do petróleo, ao promover no mesmo período a consolidação da indústria pesada e completar a transformação da pré-indústria nacional artesanal em uma indústria moderna. 
Nesse sentido, cabe promover um debate entre a interpretação de Rangel e a de Furtado sobre os elementos que permitiram a instalação da indústria pesada no Brasil. De forma bastante simplificada, enquanto um focou no papel do "capitalismo financeiro" nacional para a alocação dos recursos necessários ao esforço de industrialização (RANGEL, 1985, p. 696), o outro deu um destaque maior à penetração do capital transnacional em setores estratégicos industriais (FURTADO, 2000, p. 120).

Para Rangel (1985,p. 696-707), as condições à instalação da indústria pesada remetiam aos problemas da inflação, que corroia o valor dos investimentos, e do "capitalismo industrial brasileiro", que formara um excesso de capacidade produtiva.Em sua visão, estas questões só viriam a ser solucionadas como desenvolvimento do “capitalismo financeiro brasileiro",que permitiria a alocação de recursos necessária ao avanço da indústria pesada.Nesse sentido, a criação da correção monetária visando a sanar os problemas criados pela inflação permitiu um primeiro impulso a esse capitalismo financeiro nacional ao garantir o valor dos investimentos e empréstimos:

Garantias reais, dos tipos hipotecas e reserva de domínio, recuperavam sua plena vigência, o que trazia implícita certa tendência à queda da taxa real de juros. Em prazo brevíssimo, o Brasil viu surgir um sistema nacional de poupança [...] Os investimentos cobertos com fundos privados entraram a elevar-se, notadamente na construção residencial, liberando fundos para outras aplicações. Estava criada a escola maternal do capitalismo financeiro brasileiro (RANGEL, 1985, p. 710).

Já na avaliação de Furtado (2000, p. 116-119), a transformação do sistema capitalista no pós-Segunda Guerra foi caracterizada pelo “capitalismo das transnacionais", que buscaram ampliar seus mercados internacionais e participar dos processos de industrialização da periferia, nos quais tiveram importantes vantagens comparativas em relação às indústrias nacionais. No Brasil, a entrada dessas empresas se acelerou a partir dos anos 1950, trazendo importantes capitais e tecnologias para a consolidação do parque industrial brasileiro, dominando os setores mais dinâmicos. Mesmo assim, o autor aponta que, apesar de suas vantagens, as empresas estrangeiras não lograram controle completo da indústria nacional, tendo o Estado intervido com empresas próprias e o capital privado brasileiro se adaptado - sem nunca chegar, no entanto, a competir com o capital estrangeiro nos setores mais dinâmicos. (FURTADO, 2000, p. 120-121)

Em suma, os três autores realizam a compreensão da estrutura e evolução das realidades brasileiras a partir de seu relacionamento histórico com a economia-mundo capitalista, que é caracterizado por todos como fundamentalmente uma relação do tipo 
centro-periferia que não se manteve estável e homogênea, mas foi marcada por constantes redefinições dinâmicas dos seus canais de dependência e subordinação. $O$ consenso entre os três autores mantém-se na identificação do "motor primário" do desenvolvimento brasileiro como sendo externo à economia brasileira durante muito tempo, na medida em que sua evolução permaneceu condicionada por fatores exógenos decorrentes da dinâmica da economia-mundo capitalista.

No entanto, as nuances começam quando o potencial e a capacidade da economia brasileira para realizar transformações qualitativas em suas estruturas produtivas são analisados. Para Prado Jr., essa capacidade foi uma "ilusão", na medida em que o país permaneceu essencialmente dependente do exterior e, em sua avaliação, sua industrialização foi "falsa" por limitar-se à simples atividades de montagem sem promoção de melhora produtiva, incorporação das massas trabalhadoras e integração da economia. Para Furtado, houve envergadura do mercado interno para promover importantes transformações qualitativas em direção a uma economia industrializada e de alto grau de complexidade, que porém permaneceu subdesenvolvida ao manter uma profunda heterogeneidade socioprodutiva e a dependência do capital estrangeiro -em decorrência da "dependência cultural" das elites dominantes e da intensa participação das multinacionais em nosso parque industrial.

Já para Rangel, apesar de reconhecer a permanência de importantes elementos de subdesenvolvimento,a economia brasileira foi capaz de se adaptar à conjuntura externa e lentamente desenvolver suas próprias forças produtivas, com a dinâmica do investimento possibilitando a criação de fontes de dinamismo interno, de modo a induzir o início de ciclos econômicos propriamente "brasileiros" que foram aos poucos se sobrepujando aos ciclos da economia-mundo capitalista na determinação dos rumos da economia brasileira, apesar de não alterar radicalmente a sua condição dependente. 


\section{CAPÍTULO 3 \\ O PAPEL DA POLÍTICA EXTERNA: A DIPLOMACIA DO DESENVOLVIMENTO}

\subsection{INTRODUÇÃO}

De forma complementar às visões já abordadas e partindo de outro enfoque teórico e metodológico, a análise de política externa, apesar de seu desenvolvimento recente no Brasil ${ }^{61}$, também proporciona importantes contribuições para o estudo da inserção internacional da economia brasileira. Neste capítulo, pretende-se prosseguir com uma apreciação da política externa brasileira do período de análise proposto, visando identificar suas principais características e instrumentos de ação diplomática, e como estas contribuíram para os interesses do desenvolvimento, da soberania nacional e da ampliação do grau de autonomia externa da economia brasileira.

Na definição de Moura (1980), "política externa" pode ser entendida como "o resultado da conjugação das conjunturas políticas mais imediatas, tanto internas como externas, dentro dos condicionamentos estruturais mais amplos, que dizem respeito à totalidade do campo capitalista e o lugar que nele ocupa o país em estudo"(p. 37).Ou, de modo complementar, Pinheiro (2004, p. 7) define-a como "o conjunto de ações e decisões de um determinado ator, geralmente mas não necessariamente o Estado, em relação a outros Estados ou atores externos [...], formulada a partir de oportunidades e demandas de natureza doméstica e/ ou internacional”.

Nesse sentido, a definição de Moura (1980), ao explicitar a natureza dos elementos causais da política externa, não se limita a diferenciar os condicionantes da política externa em elementos "domésticos" e "internacionais", ressaltando também a

\footnotetext{
${ }^{61}$ Refere-se aqui ao seu desenvolvimento acadêmico e científico. Segundo Hirst (1992), o desenvolvimento da disciplina de relações internacionais no Brasil, entendida como um braço das Ciências Sociais e um campo autônomo de estudos, foi lento e tardio devido à vagarosa formação das próprias Ciências Sociais no país e à costumeira identificação das "relações internacionais" como uma conjunção de direito internacional, história diplomática e jornalismo especializado. A autora aponta que foi somente na segunda metade dos anos 70 que ocorreu uma inflexão no desenvolvimento deste campo de estudos no Brasil, quando uma série de fatores favoreceu o seu florescimento nos meios acadêmicos, em especial o crescente interesse pelos temas internacionais nas agendas de pesquisa.
} 
necessidade de identificar suas dimensões "estruturais" e "conjunturais". Enquanto os elementos estruturais limitam o campo de ação dos agentes, os conjunturais são compostos pelos processos de decisão em que esses agentes interagem. Conforme o autor, apesar de tenderem a reproduzir as lógicas estruturais, os processos de decisão têm autonomia, não sendo simples reflexos das estruturas: "As conjunturas podem atuar decisivamente sobre as estruturas; em outras palavras, os processos de decisão política também têm um potencial de transformação dos sistemas de poder" (MOURA, 1980, p.43-44).

No caso de países dependentes como o Brasil, Moura (1980) avalia que o estudo da sua política externa não pode prescindir do exame do sistema de poder no qual o país se insere, além das suas conjunturas políticas interna e externa (processos decisórios imediatos). $\mathrm{Na}$ definição do autor, um "sistema de poder", ou "esfera de poder internacional", é "uma constelação de Estados, composta por um centro hegemônico (grande potência) e sua respectiva área de influência (Estados aliados subordinados)" (MOURA, 1980, p.41-42).

À semelhança das relações entre centro, semiperiferia e periferia que caracterizam o "equilíbrio instável" da economia-mundo capitalista de Braudel, Wallerstein e Arrighi, Moura (1980) aponta que, apesar da direção geral do sistema de poder ser dada pelo seu centro hegemônico, as relações entre seus membros são instáveis, resultando em uma estabilidade provisória do sistema. Essas relações estariam no nível de análise estrutural, que no caso do sistema de poder capitalista são relações de "dominação-subordinação", que modelam a posição dos países periféricos perante o centro hegemônico.

No entanto, estas relações não se expressam somente no âmbito sistêmico, tendo sido internalizadas nos processos políticos do centro e da periferia por meio de uma "solidariedade fundamental" entre as classes dominantes nos dois lados e da disseminação de valores ideológicos visando a manter a coesão e estabilidade do sistema (MOURA, 1980, p. 42-44). Desse modo, assim como Furtado identifica a existência de uma "dependência cultural" das elites brasileiras permeando e reforçando a condição de subdesenvolvimento e subordinação ao centro da economia-mundo capitalista, para Moura (1980) este fenômeno se manifesta como uma relação de colaboração entre classes dominantes para perpetuar as estruturas do sistema.Em consequência, "a relação de dominação-subordinação se acha incrustada nos processos políticos nacionais e se manifesta em termos de ideologia política que faz convergir 
interesses de dominadores e subordinados, escondendo a verdadeira natureza da relação" (MOURA, 1980, p. 45).

No que diz respeito ao nível de análise das "conjunturas políticas imediatas", o autor constata que o processo político no centro age no sentido de perpetuar a relação de dominação-subordinação. Já no caso dos países dependentes, tendo em vista a "solidariedade" de suas classes dominantes, Moura (1980, p. 48-49) identifica no Estado o único agente capaz de exercer algum controle sobre o processo de acumulação capitalista e revertê-lo em prol do desenvolvimento nacional - reforçando-se, assim, a justificativa do foco desta dissertação na ação estatal e nos seus instrumentos de planejamento e ação estratégica.

Tendo em vista estas formulações, como definir o papel da política externa para a inserção internacional da economia brasileira? Ou seja, quais as formulações e instrumentos governamentais que atuaram na intermediação estratégica dos interesses da economia brasileira dentro da estrutura da economia-mundo capitalista?

Em primeiro lugar, não se pode perder de vista que, conforme a visão de Moura (1980), a política externa resulta de um conjunto de fatores, desde as lógicas e estruturas do sistema internacional e do corpo doméstico nacional até as diversas conjunturas e interesses envolvidos. Nesse sentido, no primeiro capítulo foram abordadas as lógicas e estruturas do sistema internacional por meio das formulações referentes à economiamundo capitalista na qual a economia brasileira possui uma posição periférica, enquanto o segundo capítulo tratou de evidenciar as transformações da estrutura socioprodutiva nacional.

No entanto, de forma a complementar esse quadro explicativo, é preciso ainda analisar o papel da evolução institucional no que diz respeito às instâncias de intermediação do país com o mundo externo. No caso da esfera pública, ou estatal, que é o objeto desta pesquisa, o leque de instituições atuantes na definição da política externa de inserção internacional da economia brasileira foi tão amplo e variado quanto os diversos grupos de interesse envolvidos no relacionamento da economia doméstica com o exterior. Assim, apesar da atuação do Ministério das Relações Exteriores (MRE) como instância privilegiada da política externa brasileira, ela não foi a única, trabalhando ao lado de outras instituições como os Ministérios do Planejamento (MP), da Indústria e do Comércio $(\mathrm{MIC})^{62} \mathrm{e}$ o da Fazenda (MF), além da

\footnotetext{
${ }^{62}$ Inicialmente, o Ministério do Planejamento foi criado em 1956 como Conselho de Desenvolvimento no governo Juscelino Kubistchek, com atribuições de coordenação e planejamento da política econômica.
} 
Superintendência da Moeda e do Crédito (SUMOC - depois Banco Central do Brasil)e o Banco Nacional de Desenvolvimento Econômico (BNDE), para citar alguns exemplos.Isto é, a política externa de inserção internacional da economia brasileira envolveu a articulação dessas diferentes instâncias políticas e econômicas, de modo conflitante ou cooperativo a depender dos seus interesses estratégicos.

Alguns autores, como Cheibub (1985, p. 113)identificam uma autonomia crescente dos diplomatas na iniciativa e controle da política externa brasileira no geral, que não nos parece viável tendo em vista a sua intensa interface com outras políticas governamentais, como a econômica e a militar, por exemplo. Ademais, a crescente gama de atores, e seus respectivos interesses, envolvidos na articulação de questões com o exterior e encontrando para isso os mais diversos canais de atuação, dificulta o monopólio da política exterior por uma única instituição.Mesmo assim, essa visão é também sustentada por Pinheiro (2004), para quem a "comunidade brasileira de política externa"63 de até pelo menos os anos 1980 teve poucos atores e instituições que se destacaram, além do MRE e seus diplomatas:

Fosse pelo baixo impacto que assuntos de natureza internacional tiveram sobre a lógica da competição político-partidária, fosse pelo relativo consenso que a política externa conseguiu instituir ou fazer parecer instituir, o fato é que esta foi uma das políticas públicas mais insuladas do debate político. (PINHEIRO, 2004, p. 9)

Em nossa visão, apesar da posição privilegiada do MRE, o Estado brasileiro não se limitou a acionar apenas uma instituição na condução de sua política externa, nem estase manteve imune aos jogos de interesses dos diversos grupos que afligem a máquina estatal. Pelo contrário, a política externa brasileira resultou da conjugação de estratégias de diversas instituições e grupos de interesses, a depender da natureza das esferas envolvidas (se econômica, social, militar e/ou cultural, por exemplo), agindo entre si de forma dinâmica e nem sempre cooperativa, em um permanente jogo de disputa por recursos de poder.

No entanto, tendo em vista que a maior parte das análises de política externa tende a focar na atuação do MRE e que, dentro dos objetivos desta dissertação faz-se

Foi transformado em Ministério em 1962 no governo de João Goulart, tendo Celso Furtado na chefia com o objetivo de elaborar um programa de governo lastreado na égide desenvolvimentista. Já o Ministério da Indústria e do Comércio foi criado em 1960 como separação do antigo Ministério do Trabalho, Indústria e Comércio (que virou Ministério do Trabalho), tendo sido transformado em Ministério do Desenvolvimento, Indústria e Comércio somente em 1999.

${ }^{63}$ No conceito de Souza (2002, p. 15), a "comunidade brasileira de política externa designa o universo constituído por pessoas que participam do processo decisório e/ou contribuem de maneira relevante para a formação da opinião no tocante às relações internacionais do país". 
importante avaliar as interpretações produzidas no âmbito desta área de conhecimento, este capítulo focará na atuação do MRE, deixando uma análise mais detalhada do papel das demais instituições político-econômicas apontadas para os próximos capítulos.Além disso, no caso da esfera econômica o MRE desempenhou de fato um importante papel, principalmente no contexto do pós-Segunda Guerra, consubstanciando-se ao longo dos anos como um instrumento do projeto de desenvolvimento nacional.

Destarte, tendo como objetivo principal pincelar os traços gerais da política externa de inserção internacional da economia brasileira a partir da atuação do MRE, este capítulo subdivide-se em mais duas partes além do esforço de síntese no final. A primeira parte foi destinada a abordar como a evolução institucional do MRE e a transformação do panorama internacional contribuíram para a construção de uma "tradição" ou "linha de continuidade" da diplomacia nacional, quando a política externa acabou se consubstanciando na segunda metade do século XX como um instrumento de apoio ao desenvolvimento; e a segunda parte busca evidenciar como essa "diplomacia do desenvolvimento" se adequou e transformou frente às mudanças sofridas pela ordem internacional e à evolução da própria estrutura produtiva doméstica.

\subsection{A EVOLUÇÃO INSTITUCIONAL DO ITAMARATY E AS MUDANÇAS NO CONTEXTO INTERNACIONAL: FORJANDO UMA TRADIÇÃO DE POLÍTICA EXTERNA}

Toda política exterior se funda sobre bases de poder e meios de ação (recursos econômicos, poder populacional, características nacionais, etc.). Na sua formulação influem, portanto, os fatores econômicos, a opinião pública, as forças religiosas, os grupos de interesses e a tradição.(RODRIGUES,1966, p. 47)

Existe uma complexa relação entre a evolução institucional do Ministério das Relações Exteriores (MRE), a evolução da estrutura de poder internacional e a consolidação de uma "tradição" balizadora da diplomacia brasileira, expressa por meio de um "estilo" diplomático e de um "ideal” de política externa. De um lado, o desenvolvimento histórico do MRE teve importantes implicações para a configuração da sua arena de atuação na política externa brasileira, ao construir uma estrutura burocrática de estilo peculiar na intermediação com o mundo exterior. De outro lado, 
esse estilo de atuação sempre foi moderado por fatores internos - como os processos decisórios domésticos e a estrutura de poder nacional -, e externos - como as relações com o centro hegemônico e as demais partes do sistema -, especialmente no que diz respeito à construção da identidade nacional perante o mundo e à defesa de seus interesses, tendo em vista a posição periférica do país em uma economia-mundo capitalista cuja lógica de funcionamento é orquestrada por um grupo limitado de países centrais.

Conforme Cheibub (1985), a evolução institucional do MRE foi marcada por dois períodos cruciais: a gestão do Barão do Rio Branco (1902-1912), e a gradual "racionalização e burocratização" do ministério e da carreira diplomática que se seguiu após a sua gestão ${ }^{64}$. Importante marco da história do MRE, o autor aponta que o Barão angariou prestígio e reconhecimento para a diplomacia brasileira: "a administração do Barão significou a verdadeira fundação do Itamaraty moderno. Atualmente o Ministério das Relações Exteriores busca suas raízes nos feitos de Rio Branco, com poucas referências ao período imperial" (CHEIBUB, 1985, p. 120).

Boa parte dessa áurea deveu-se ao seu carisma e, especialmente, ao seu sucesso em concluir a configuração das fronteiras territoriais brasileiras de forma pacífica e diplomática, resolvendo algo que fora objeto de conflito por mais de quatro séculos e que foi fundamental para a formação do Estado nacional brasileiro. Nas palavras de Lima (2005), o sucesso da gestão do Barão em definir as fronteiras nacionais sem recorrer à guerra, resolvendo uma antiga questão brasileira com seus vizinhos latinoamericanos por meio da negociação, se idealizou em um "mito fundador dos serviços exteriores” (p. 1) que contribuiu para a identificação da política externa com as questões de Estado, desvinculada dos conflitos e facções partidárias da política doméstica.

Após a gestão de Rio Branco, Cheibub (1985, p. 123) foram implementadas reformas administrativas que transformaram o MRE em uma estrutura racional e burocrática, no bojo de um processo maior de modernização do Estado brasileiro iniciado nos anos 1930 e 1940. Foi quando começaram os concursos para a carreira pública e houve a estruturação de muitas das carreiras civis, a padronização dos serviços públicos e outras medidas de racionalização do Estado. No MRE, além da

\footnotetext{
${ }^{64} \mathrm{Na}$ realidade, o autor divide a história institucional do MRE em três fases: o "Período Patrimonial" de 1822 ao fim do século XIX, em que não havia diferenciação entre os diplomatas e a elite burocrática estatal e imperial; o "Momento Carismático" no inicio do século XX, correspondente à gestão de Rio Branco; e o "Período Burocrático-Racional"de1910 em diante, quando se iniciam grandes reformas administrativas visando à racionalização e burocratização do MRE e da carreira diplomática no Brasil.
} 
reestruturação administrativa ${ }^{65}$, destacou-se ainda a criação do Instituto Rio Branco em 1945 como escola de formação e aperfeiçoamento de diplomatas, que assumiu o monopólio da seleção e formação dos diplomatas brasileiros.

Conforme Lima (2005), a estabilidade e ação desse corpo diplomático restrito foram fortalecendo o "mito" ao longo do tempo, solidificando uma percepção dentro do MRE de que o lugar legítimo da política externa era na agenda do Estado,tendo em vista o principio constitucional da competência do Executivo na condução da política externa e permitindo a sua especialização em relação às demais políticas públicas e aos debates nacionais.Na visão da autora, o fortalecimento do mito também está relacionado:

a uma aspiração compartilhada pelas elites brasileiras desde o inicio da formação nacional do país, a saber, a crença de que o país está destinado a ter um papel significativo na cena nacional e o reconhecimento desta condição pelas principais potências mundiais, em função de suas dimensões continentais, de suas riquezas naturais e da 'liderança natural' entre os vizinhos. (LIMA, 2005, p. 3)

Na realidade, Lima (2005,p. 8-9) aponta que essa “aspiração”está relacionada à visão específica de identidade nacional construída pelas elites brasileiras ao longo dos séculos, tendo se consolidado como a ideologia que permeou a agenda diplomática do MRE e pela qual essa instituição se legitimou como instrumento ao projeto de desenvolvimento nacional.

Rodrigues (1966, p. 92) ressalta, contudo,que a atuação do MRE permaneceu por muito tempo subordinada à interpretação das minorias dirigentes sobre o que constitui o "interesse nacional", que nem sempre coincidiu com o real interesse da sociedade brasileira. Em sua definição, o interesse nacional corresponde ao somatório dos interesses do povo e da União ${ }^{66}$, ao qual a política externa deveria servir, porém, são recorrentes os problemas na sua interpretação pelas elites dominantes, que confundem seus interesses com os nacionais.

Portanto, qualquer dúvida sobre o interesse nacional reside não no seu sentido, mas na sua interpretação, que foi feita por forças minoritárias, representando infidedignamente a maioria nacional [...] os interesses nacionais têm sido, na nossa história, só os interesses da minoria e não os do povo. (RODRIGUES, 1966, p. 79)

\footnotetext{
65 Segundo Cheibub (1985, p. 124-126), nesse período reergueu-se a estrutura administrativa da sua Secretaria de Estado e programou-se as Reformas Mello Franco (1931) e Oswaldo Aranha (1938). Estas reformas unificaram os serviços do MRE, facilitando a integração interna do MRE e a coordenação da política externa; e reformaram a carreira diplomática de modo a torná-la mais meritória.

${ }^{66}$ Por interesses do povo, o autor entende ser educação, saúde, bem-estar e garantias individuais; já por interesses da União, ele entende ser a unidade política, integridade territorial,desenvolvimento econômico nacional e regional e o regime representativo. (RODRIGUES, 1966, p. 89-92)
} 
Para o autor, esta "aspiração" que permeou a tradição diplomática do MRE remonta em suas origens ao tema da autonomia, o "fim essencial de toda política externa brasileira que, ontem como hoje, tem sido obter o direito de ter uma orientação própria” (p. 70). Em sua visão, esse caráter da diplomacia brasileira sobressaiu-se, dentre os demais fundamentos do MRE, por ter sido uma constante na medida em que todos os outros foram variáveis, representando objetivos essenciais à nação que independem de grupos de interesses e que são permanentes na história, a saber: "a defesa da independência e da soberania, da integridade territorial e das relações pacíficas” (RODRIGUES, 1966, p. 47).

Além disso, como lembram Lima e Hirst (2006, p. 20-22), pelo menos a partir do século XX o país esteve sujeito ao poderio e influência dos Estados Unidos em decorrência da sua localização geográfica no continente americano e da sua posição periférica na economia-mundo capitalista, fazendo parte da esfera de segurança continental americana, o que junto ao contexto regional estável ajuda a explicar a percepção da "comunidade de política externa" brasileira de que as principais ameaças externas do país são econômicas, e não militares ou de segurança. Isso acabou se expressando na busca brasileira por maior autonomia nas arenas internacionais, evidenciando sua faceta econômica e dando-lhe um viés desenvolvimentista.

Conforme Visentini (2008, p. 11), o deslocamento do eixo da diplomacia brasileira entre os séculos XIX e XX para os Estados Unidos significou a sua transformação em uma diplomacia mais restrita ao âmbito hemisférico,depois de quase quatro séculos tendo sua inserção externa processada por intermédio de potências europeias como Portugal e Inglaterra. Ainda segundo o mesmo autor, esta transformação se deu em um contexto de gradativa afirmação da hegemonia norteamericana, em que os Estados Unidos eram vistos como a nova potência mundial capaz de impulsionar a ascensão de seus aliados no seu caminho ao topo da economia-mundo capitalista.

Porém, Visentini (2008, p. 10) avalia que aos poucos a relação com os Estados Unidos começou a se mostrar insuficiente, e até contrária, à vinculação estratégica da política exterior às necessidades do processo de desenvolvimento nacional. Assim, a partir dos anos 1960, "na esteira do desenvolvimento industrial, a política exterior brasileira procurou novos espaços, por meio da mundialização e da multilateralização [...] a busca por criar condições para o desenvolvimento industrial tornou-se o objetivo central da política externa" (VISENTINI, 2008, p. 10). 
Na realidade, a política externa brasileira pós-Segunda Guerra oscilou entre duas posturas que se relacionaram de modos diferentes aos interesses do desenvolvimento: o foco no relacionamento bilateral com os Estados Unidos e o compromisso com o multilateralismo (PINHEIRO, 2004, p. 7-8; LIMA E HIRST, 2006, p. 21). Essas duas tendências se alternaram ao longo da trajetória da diplomacia nacional, muitas vezes se interpenetrando, a depender das possibilidades e restrições apresentadas em cada momento pelo panorama internacional e pelos jogos de poder nacionais, tendo em vista a leitura feita pelas elites dominantes dos interesses do pais.

De certo modo, a alternância entre uma orientação diplomática mais favorável ao alinhamento com os Estados Unidos e outra mais pendente à diversificação das relações internacionais dependeu, seguindo a visão de Moura (1980), das estratégias consideradas mais adequadas para viabilizar o projeto de desenvolvimento nacional a partir das estruturas e conjunturas internas e externas do país. Como em um pêndulo, o objetivo do desenvolvimento nacional foi tratado de modos diversos ao longo de dois extremos de oscilação, dados pelo alinhamento automático aos Estados Unidos de um lado, e pelo multilateralismo de outro.Portanto, a evolução da política externa brasileira desse período oscilou entre um extremo e outro, às vezes parando em um ponto qualquer ao longo do caminho conforme as transformações do sistema internacional e das estruturas internas, e a depender da conjugação de interesses internos e externos, mas sempre tendo em vista a sua importância como um instrumento de apoio aos interesses do desenvolvimento nacional.

\subsection{OS PARADIGMAS "AMERICANISTA" E "GLOBALISTA"}

Em linhas gerais, a partir da segunda metade do século XX a tradição de servir como um instrumento aos objetivos do desenvolvimento nacional moldou de tal modo a agenda externa que, apesar das diferentes estratégias econômicas e das mudanças das demais prioridades da diplomacia nacional, a atuação do MRE foi, desde então, sempre condicionada pela questão do desenvolvimento (LIMA E HIRST, 2006, p. 22).

No entanto, conforme Rodrigues (1966), antes disso, o corpo diplomático brasileiro foi essencialmente "dinástico", representativo das oligarquias rurais e não dos interesses do povo, resultando em uma política externa alinhada com os interesses dos 
centros da economia-mundo capitalista:"abstencionista, omissa, ela se refugia na solução jurídica e serve com a maior submissão aos interesses gerais dos Grandes Poderes, na suposição de que o que é bom para eles é bom para nós.” (p. 64).

$\mathrm{Na}$ realidade, essa avaliação reflete o fato de que,sendo parte constituinte da economia-mundo capitalista desde a sua colonização, o Brasil sempre esteve sujeito, a cada ciclo de acumulação sistêmica, à lógica e ao poderio político e econômico do núcleo vigente de dinamismo capitalista. Em específico, a sua política externa sempre teve que se moldar às condições internacionais e foi condicionada pela leitura das classes dominantes sobre os meios mais adequados de auferir o seu entendimento de interesses nacionais. Desse modo, a política externa brasileira no século XX não pode ser explicada sem considerar o histórico das suas relações com os Estados Unidos e as implicações da dinâmica do ciclo sistêmico de acumulação capitalista norte-americano sobre a economia brasileira.

Conforme Pinheiro (2004), o Barão de Rio Branco já em sua gestão percebera os Estados Unidos como o novo polo de poder mundial em ascensão, uma potência que buscava se expandir internacionalmente, garantir a hegemonia político-econômica nas Américas e colocar o Brasil em sua zona de influência.Ademais, apesar de permanecer o modelo econômico agrário-exportador, o foco deslocara-se do açúcar do nordeste para o café do sul, que tinha no mercado norte-americano seu principal destino de exportação. Desse modo, o interesse nacional passou a ser identificado com os interesses do café, de tal modo que "a política externa defendia a aproximação com Washington, atendendo ao verdadeiro interesse nacional do país" (PINHEIRO, 2004, p. 13).

Destarte, buscou-se uma relação preferencial com os Estados Unidos, visando obter vantagens dessa aproximação e aumentar os recursos de poder do Brasil no sistema internacional pela associação à nova potência hegemônica. Foi quando se iniciou o chamado paradigma americanista da política externa brasileira, que se pautou na "formulação de um projeto que, por meio da aproximação dos Estados Unidos, buscava dar ao país um lugar de destaque no cenário internacional" (PINHEIRO, 2004, p. 21). No entanto, um conjunto de fatores estruturais e conjunturais, externos e internos, acabou implicando na revisão desse americanismo.

Conforme Moura (1980), no período entre guerras de 1935-1942, a esfera de poder internacional se rearticulou de modo a permitir a estruturação de novos sistemas de poder. Na interpretação do autor, as relações entre países até a Primeira compunham 
vários sistemas de poder, com alguns países da Europa no centro. Após a Segunda Guerra, esses sistemas de poder antes existentes foram substituídos por apenas dois, o dos Estados Unidos e o da União das Repúblicas Socialistas Soviéticas. (MOURA, 1980, p. 51-53).

Para a América Latina, a desarticulação dos sistemas de poder europeus no período entre guerras teve importantes implicações. Moura (1980) aponta que, com o enfraquecimento da Inglaterra e a ascensão de novas potências, a hegemonia britânica na região recuou para dar lugar a um confronto entre Estados Unidos e Alemanha, dois aspirantes a potência internacional.Para ambas as nações, a América Latina figurava como importante fornecedora de primários e de mercados consumidores de manufaturados, diante da necessidade enfrentada pelos dois países de conquista de mercados externos para sustentar a expansão de suas economias. (MOURA, 1980, p.5456).

É importante ressaltar que, como aponta o autor, no Brasil, o recuo inglês não reduziu a dependência econômica, apenas substituiu o tipo de centro dominador. Sendo os Estados Unidos produtores de manufaturados e de primários, enquanto a Inglaterra era apenas produtora de manufaturados, o autor avalia que a "complementaridade" econômica entre centro e periferia foi reduzida, piorando a relação de dependência brasileira com o novo centro. (MOURA, 1980, p. 56)

Foi quando Roosevelt (1933-1945) desenvolveu a sua "política de boa vizinhança", substituindo a política de intervencionismo norte-americana na América Latina por outra de negociações e colaboração, visando a assegurar a liderança dos Estados Unidos, frear a influência europeia e estimular a estabilidade entre países do continente. Com as perspectivas da Segunda Guerra,a ampliação estratégica da "área de segurança" americana tornara-se fundamental, de modo que o "cinturão" PacíficoCaribe-América Central passou a incluir também a América do Sul. Em especial, “a saliência de leste" formada pelo Nordeste brasileiro passou a ser considerado ponto vital da segurança norte-americana. Além disso, essa política atendia também ao esforço de recuperação econômica norte-americano, que necessitava expandir seus mercados de exportação de manufaturas, além de abastecer-se de alguns insumos. (MOURA, 1980, p.58-59)

Desse modo, Moura (1980, p. 62) aponta que o período entre guerras caracterizou-se pela concorrência entre dois sistemas de poder, em que a Alemanha, por motivos econômicos (o fornecimento de primários), disputou com os Estados Unidos, 
por motivos estratégicos (o alinhamento), a área de influência brasileira, ampliando os limites da decisão do Estado brasileiro. Internamente, os grupos de interesse brasileiros conflitavam: os agroexportadores dividiam-se entre Washington e Berlim, os industriais buscavam insumos e equipamentos em ambos os países, enquanto os financistas ligavam-se ao eixo Nova York-Londres.

Portanto, na avaliação do autor, nem o sistema de poder do qual o Brasil iria fazer parte estava definido, nem a conjuntura política brasileira era uniforme, levando a uma política de indefinições ou "equidistância pragmática" entre os dois polos. Foram aproximações alternadas e simultâneas, frutos da luta política interna, que durou enquanto os dois sistemas de poder tinham capacidade de acesso similar ao Brasil. Porém, com o início da Segunda Guerra Mundial,o acesso alemão sofreu obstáculos, reduzindo fortemente o comércio como Brasil. Nas palavras de Moura, a Segunda Guerra foi o "ponto de virada" (1980, p. 63), quando o peso norte-americano fez-se sentir nas decisões internas.

Durante a guerra, o efetivo alinhamento à potência norte-americana foi trocado por concessões e benefícios econômicos e militares, como o financiamento à implantação da siderurgia nacional e o reequipamento das forças armadas brasileiras. Assim, o americanismo foi se consolidando como paradigma da política externa brasileira, sendo percebido como um meio de garantir os interesses nacionais e alcançar os objetivos de desenvolvimento.No entanto, terminada a guerra, o relacionamento com os Estados Unidos foi-se logo revelando uma frustração, na medida em que não correspondeu às expectativas brasileiras de apoio concreto ao seu desenvolvimento nacional.

Mais uma vez, um conjunto de fatores estruturais e conjunturais, internos e externos, contribuiu para delinear um progressivo realinhamento de expectativas. Conforme Visentini (2008, p. 15-19), o alinhamento não se mostrou recompensador porque as prioridades dos Estados Unidos no pós-guerra se voltaram à reconstrução da Europa Ocidental e ao confronto bipolar em formação, com a América Latina deixando de ser prioritária. Ou seja, o contexto do confronto ideológico entre o ocidente capitalista e o oriente comunista diferia radicalmente da realidade da guerra, implicando na alteração da política exterior norte-americana para a América Latina e o Brasil.

De sua parte, a situação interna brasileira também estava em transformação: segundo Visentini (2008, p. 15-19), o processo de industrialização avançava e um novo perfil sociopolítico urbano-industrial surgia, com a afirmação de uma burguesia média, 
de uma classe operária em expansão e o aumento da participação política. O programa de desenvolvimento industrial do governo pressionava para o avanço da indústria de base, que exigia a aquisição de capitais e tecnologias estrangeiros. Como as alternativas de multilateralização tinham limites na época - o mundo socialista era "inimigo", a Europa Ocidental e o Japão estavam destruídos, e o Terceiro Mundo engatinhava - o apoio norte-americano configurava-se essencial: “A obtenção de capitais e tecnologia só poderia ser lograda pelo incremento da cooperação econômica com a potência então hegemônica do mundo capitalista, os Estados Unidos" (VISENTINI, 2008, p. 17).

Assim, o segundo governo Vargas retomou um modelo nacionaldesenvolvimentista, que buscou angariar o apoio norte-americano para seu plano de industrialização negociando os termos do alinhamento brasileiro na Guerra Fria: "a política externa do novo governo Vargas ficou conhecida pelo termo 'barganha nacionalista', pela qual se procurava negociar o apoio político-estratégico à Washington pela ajuda ao desenvolvimento econômico" (PINHEIRO, 2004, p. 29). No entanto, os interesses norte-americanos no contexto da Guerra Fria diferiam dos mesmos nos anos de guerra, não oferecendo as mesmas condições de negociação do primeiro governo Vargas, quando a "equidistância pragmática"fora possível, de tal modo que a negociação do alinhamento brasileiro aos Estados Unidos não rendeu os frutos esperados.

Na avaliação de Lima e Hirst (2006), o Brasil nunca teve grande relevância relativa para os interesses dos Estados Unidos na política e segurança mundial. Em consequência, a esperança de que o alinhamento à Washington se traduziria em uma posição privilegiada de aliado especial norte-americano nunca se concretizou, tendo a boa vontade norte-americana para com as aspirações brasileiras oscilado conforme os jogos de interesses e circunstâncias de poder:

As relações Brasil-Estados Unidos transitaram por diferentes fases, oscilando entre "bom" e "frio" sem nunca culminarem em ampla hostilidade. Os dois estados partilharam uma noção de 'divergências limitadas' que, enquanto sempre evitando a confrontação aberta, resultou em frustrações em ambos os lados. (LIMA e HIRST, 2006, p. 33).

No governo subsequente de Juscelino Kubistchek, a necessidade de capitais e tecnologias americanas ainda fazia-se crucial para o sucesso do programa de desenvolvimento, de modo que o apoio norte-americano também foi buscado, desta vez por meio de uma nova abordagem consubstanciada na Operação Pan-Americana (OPA), "uma proposta multilateral latino-americana que objetivava fomentar a revisão [das 
relações com os EUA]" (PINHEIRO, 2004, p. 31).Com o argumento de que a condição do subdesenvolvimento e da miséria era um estímulo aos problemas sociais e à instalação do comunismo nesses países, a OPA buscou atrair investimentos oficiais norte-americanos para avançar a industrialização brasileira e promover $\mathrm{o}$ desenvolvimento da América Latina.(PINHEIRO, 2004, p. 31-32)

Na avaliação de Pinheiro (2004), os resultados foram modestos, com os Estados Unidos preferindo investir por meio de suas empresas transnacionais e condicionando a concessão de empréstimos à adoção de medidas econômicas restritivas: "Em termos concretos, a OPA logrou apenas o aumento da assistência técnica norte-americana para a América Latina e a criação do Banco Interamericano de Desenvolvimento” (p. 32). Para Rodrigues (1966), apesar de a OPA ter "regionalizado"a política externa brasileira ao manter o alinhamento com os Estados Unidos, ela teve o mérito positivo de "ligar as necessidades internas às diretrizes internacionais, mostrando que a política internacional podia e devia ser um instrumento nacional de desenvolvimento econômico" (p. 66).Em sua visão, Kubitschek usou a política externa para viabilizar o uso das potencialidades brasileiras e assim abreviar o prazo de desenvolvimento, em uma política de desenvolvimento intensivo que demonstrou a importância da política externa como instrumento do desenvolvimento.

Na realidade, para além desse processo progressivo de frustração com a postura norte-americana, as transformações da economia-mundo capitalista e da própria economia brasileira ocorridas nesse período também foram essenciais para impulsionar a revisão do paradigma americanista da política externa brasileira. Dentre as transformações sistêmicas, Pinheiro (2004, p. 33-34) destaca a descolonização afroasiática e a recuperação da Europa Ocidental e do Japão, que aumentaram o número de atores relevantes no concerto internacional,dando alternativas à diplomacia brasileira. Assim, à medida que o desapontamento com os Estados Unidos crescia, foi-se intensificando um movimento de aproximação com outras potências em uma busca por novos parceiros econômicos, que acabou gerando um novo paradigma, chamado globalista, "que elegia a diversificação das relações exteriores do Brasil como condição para o aumento do seu poder de barganha do mundo" (PINHEIRO, 2004, p. 34-35).

Além disso, conforme lembra Rodrigues (1966, p. 65), o término da Segunda Guerra Mundial despertara uma onda de maior participação dos países periféricos nas arenas internacionais visando a promover o seu desenvolvimento, condição possibilitada pela criação de novos fóruns multilaterais como o FMI, o BIRD, o GATT 
e a ONU.Isto é, o Brasil encontrou um espaço, antes inexistente, para participar mais ativamente das grandes decisões internacionais e aos poucos assumir um discurso de uma nova ordem internacional junto às demais nações do Terceiro Mundo.

Na realidade, conforme Lima (2005, p. 4), o envolvimento brasileiro em fóruns multilaterais foi um comprometimento deliberado que data desde o fim do século XIX, tendo constituído uma forma de buscar maior reconhecimento internacional através de ativa participação nas discussões multilaterais. No geral, após a Segunda Guerra o Brasil buscou reconhecimento nas arenas multilaterais assumindo uma posição mediadora entre países "fracos" e "fortes", defendendo os direitos dos países periféricos ao mesmo tempo em que aspirava ao status do centro. Para Lima (2005), essa combinação de elementos contrários resultou em uma posição ingrata ao país, visto que ambígua ao defender o ideal de uma ordem internacional igualitária e ao mesmo tempo em que aceitava a desigualdade de representação política diante das diferenças nos recursos de poder: "o mediador sofre de uma dissonância permanente entre seus objetivos particulares [...] e os objetivos coletivos dos países que supostamente representa" (p. 5).

No entanto, a autora aponta que nas questões econômicas, o Brasil pôde exercer o papel de mediador com maior legitimidade e coerência, defendendo junto ao grupo dos países pobres a compensação do desequilíbrio comercial entre parceiros econômicos desiguais e pleiteando condições para o desenvolvimento do Terceiro Mundo. Ou seja, a existência de um objetivo comum ao mediador e ao grupo dos países atrasados abriu espaço para o Brasil, como potência média, liderar e coordenar a ação coletiva do grupo.(LIMA, 2005, p.5-6)

Nesse sentido, cabe destacar a criação da Comissão Econômica para a América Latina (Cepal) em 1947 no âmbito da Organização das Nações Unidas, em meio a uma atmosfera de queixa dos países latino-americanos diante da sua exclusão do Plano Marshall e com forte oposição norte-americana. Logo os trabalhos da Cepal começaram a dar substância teórica aos processos de industrialização promovidos pelos países latino-americanos como meio de superar a dependência econômica, legitimando a intervenção estatal como necessária para garantir esses resultados por meio da programação das atividades econômicas e da realocação de recursos.

Desde o início, a Cepal foi associada às ideias de Prebisch, que foi convidado para ser seu secretário-executivo e cujo ensaio "O Desenvolvimento Econômico da América Latina e alguns dos seus principais problemas" (1949), mais conhecido como 
"Manifesto Latino-Americano", tornou-se a gênese do pensamento da organização ao concretizar as formulações sobre a estrutura do sistema capitalista internacional em relações do tipo centro-periferia e propor a industrialização como um meio do continente superar sua condição de subdesenvolvimento.Logo o Brasil começou a debater na Comissão temas como industrialização em países subdesenvolvidos e planejamento econômico, inclusive tendo brasileiros fazendo parte da equipe de pensadores latino-americanos reunida por Prebisch, como Celso Furtado, cujas contribuições foram fundamentais para as formulações sobre o estruturalismo e a dependência.

As ideias produzidas pela Cepal foram formulações originais que alcançaram grande difusão, oferecendo novas interpretações sobre o funcionamento do sistema capitalista internacional e a condição de subdesenvolvimento da periferia latinoamericana. Conforme Barbosa (2012, p. 225), o alcance dessas ideias foi além de influenciar as políticas dos governos da região, logo sendo percebido que sua aplicação não se restringia à América Latina, mas abrangia toda a periferia mundial. Foi quando Prebisch começou a aventar a possibilidade de extrapolar a missão cepalina a todo o Terceiro Mundo, que acabou culminando com a transformação em 1964 da Conferência sobre Comércio e Desenvolvimento das Nações Unidas em instituição, a UNCTAD, um espaço para pesquisa e negociação a serviço dos países em desenvolvimento, à semelhança da Cepal, só que de escala mundial.

Ainda no plano das ideias, em paralelo a essas discussões sobre a dinâmica Centro-Periferia, Cabral (1997, p. 14) analisa que no Brasil dos anos 1950 surgiu um novo conceito de "ser nacional", uma nova leitura da realidade brasileira e de sua posição no mundo. O autor aponta que, com a criação em 1949 da Escola Superior de Guerra (ESG) e do Instituto Superior de Estudos Brasileiros (ISEB)em 1955, constituíram-se dois importantes centros de estudos sobre um novo protagonismo do Brasil no mundo, ideia que se tornaria a base consensual da elite dirigente brasileira "de criar um país desenvolvido, urbano e industrializado" (CABRAL, 1997, p. 22).

Referindo-se às obras do diplomata Francisco Clementino de San Tiago Dantas, que proferira palestras e realizara estudos para a ESG, e do militar Golbery do Couto e Silva, professor e pesquisador na mesma instituição, como representativas das ideias desenvolvidas pela ESG nesse período, o autor aponta que ambos pensadores desenvolveram um diagnóstico da realidade nacional para investir em um projeto de país industrializado e protagonista no cenário internacional. Na visão de Cabral (1997), 
ambos foram fundamentais para a formação e propagação de uma "ideologia desenvolvimentista aliada a um nacionalismo crítico e realista" (p. V) do posicionamento geopolítico e estratégico do Estado brasileiro no contexto da Guerra Fria.

Nesse sentido, para o autor, as ideias do período pareciam convergir, apesar de suas diferenças de abordagens e nuances de foco, para uma visão do Brasil como um país em desenvolvimento que se industrializava em direção a um maior protagonismo político e econômico no cenário internacional. Ou seja,

Nacionalismo e desenvolvimento tornava-se o binômio a comandar a alta política do país. Forjava-se, em consonância com este ideário, uma política externa independente, que deslocava o eixo de posições internacionais brasileiras [...] de Washington para a consideração exclusiva do interesse nacional brasileiro. Para a elite e para o povo criava-se um amplo consenso nacional, na antevisão do Brasil como um país em desenvolvimento, que emergia como uma nação protagônica em meio aos embates da guerra fria [...] Superando os ditames do conflito Leste-Oeste, a posição do Brasil tornava-se um dos pilares do chamado Terceiro Mundo, um bloco formado pelas excolônias da África e Ásia, os não-alinhados e os países em desenvolvimento (CABRAL, 1997, p.56-57).

Portanto, a conjugação de todos esses fatores - estruturais, conjunturais e ideológicos - contribuiu para delinear o novo paradigma globalista da política externa brasileira em substituição ao americanismo anterior. Conforme interpretação de Pinheiro (2004, p. 34-35), com uma visão mais realista e pragmática das relações internacionais, o globalismo buscou despir-se de ideologias enrijecedoras e de alinhamentos automáticos, voltando-se à diversificação de suas relações internacionais como meio de elevar os recursos de poder do país e viabilizar seu projeto de desenvolvimento. Para isso, alguns dos princípios tradicionais do MRE foram retomados como fundamentos, como o da não-intervenção, da autodeterminação dos povos, da igualdade jurídica das nações e da solução pacífica de controvérsias.

Embora esse processo tenha iniciado no segundo governo Vargas, somente "na Política Externa Independente de Jânio Quadros e João Goulart, entre 1961 e 1964, que ele se configurou de forma explícita" (VISENTINI, 2008, p. 11).Para o autor, a política externa do segundo governo Vargas e dos governos populistas dos anos 1950 representou uma estratégia de barganha com Washington visando a obter apoio ao desenvolvimento industrial brasileiro. Diante da falta de resposta significativa por parte dos Estados Unidos, aliada às necessidades do processo de desenvolvimento brasileiro e à intensa fermentação intelectual acerca das realidades do país e suas possibilidades 
estratégicas para uma inserção mais destacada no cenário internacional,as lideranças nacionais teriam se convencido, aos poucos, da necessidade de ampliar os vínculos internacionais do Brasil e escapar à dependência hemisférica norte-americana. (VISENTINI, 2008, p.22-25)

A "primeira manifestação sistemática das teses do globalismo" (PINHEIRO, 2004, p. 36) foi a chamada "política externa independente" dos governos Jânio Quadros e João Goulart. Apesar de ainda não existir condições ideais para a implementação desse novo paradigma, que exigia um grau de autonomia internacional inexistente do país, promoveu-se um grande avanço, especialmente com a substituição da Guerra Fria como questão central das relações exteriores brasileiras pelo conflito Norte-Sul. Conforme Visentini (2008, p. 23), os princípios da "política externa independente" foram:

1. Exportações brasileiras para todos os países, inclusive socialistas. 2. Defesa do Direito Internacional, da autodeterminação e da nãointervenção nos assuntos internos de outros países. 3. Política de Paz, desarmamento e coexistência pacífica nas relações internacionais. 4. Apoio à descolonização completa de todos os territórios ainda submetidos. 5. Formulação autônoma de planos internacionais de desenvolvimento e de encaminhamento da ajuda externa.

Assim, o Brasil buscou se afastar da política colonialista de Portugal, adotou independência na disputa bipolar ao apoiar Cuba, aproximou-se do Leste Europeu e da China, reatou relações com a URSS e passou a denunciar as regras do comércio internacional que prejudicavam o Terceiro Mundo. Nas palavras do autor,

a Política Externa Independente constituiu uma estratégia coincidentemente utilizada para questionar o status quo mundial e negociar uma nova forma de inserção internacional do país ou, dito mais claramente, renegociar o perfil da sua dependência. [...] Em termos econômicos, a PEI pode ser considerada uma reação à deterioração dos termos do comércio exterior, devido sobretudo à queda contínua dos preços das matérias-primas e dos produtos agrícolas, daí a busca constante de novos mercados. Ela também pode ser entendida como um instrumento diplomático do interesse nacional, isto é, como elemento de apoio do processo de desenvolvimento industrial brasileiro (VISENTINI, 2008, p. 28).

Portanto, a política externa independente veio a completar o processo iniciado com a "barganha nacionalista" de Vargas e Kubistchek, de transição de uma diplomacia atrelada aos interesses norte-americanos e inserção hemisférica para uma política externa mais complexa e multilateral, em "um projeto coerente, articulado e sistemático visando transformar a atuação internacional do Brasil” (VISENTINI, 2008, p. 29).No 
entanto, na visão do autor, essa nova inserção internacional buscada por meio da política externa independente na realidade "diversificou" o seu espectro de dependência ao incluir outros centros de dinamismo, como a Europa Ocidental e o Japão, ao mesmo tempo em buscou a associação com outros países da periferia e semiperiferia, em uma nova atuação do país junto ao Terceiro Mundo.

Porém, com o Golpe Militar de 1964, o americanismo voltou a orientar a política externa brasileira, retomando a bipolaridade Leste-Oeste para enfatizar a questão da segurança contra a ameaça comunista como um requisito para o desenvolvimento. Nesse contexto, a dependência brasileira do "centro hegemônico ocidental" passou a ser vista como natural, identificando a associação ao capital estrangeiro (especialmente o norte-americano) como meio para avançar o processo de industrialização. Desse modo, Castelo Branco abandonou o terceiro mundismo, o multilateralismo e os demais princípios da política externa independente, retomando a diplomacia hemisférica, o alinhamento aos Estados Unidos e a ideologia da Guerra Fria. Segundo Pinheiro (2004), a tradição de pensamento diplomático desenvolvimentista que já se consolidara no MRE ao longo dos últimos anos, tendente a "subordinar a ideologia ao pragmatismo dos interesses", teve que ser deixada de lado perante a forte ideologia do novo regime, "a fim de evitar a caça às bruxas que se implantava em outras agências" (PINHEIRO, 2004, p. 39).

Porém, se por um lado a aliança com os Estados Unidos fortaleceu o governo militar, financiando seu projeto de poder nacional e legitimando internacionalmente o golpe de 1964, por outro lado ela não se traduziu nem em assistência econômica, nem em ganho de meios de poder internacional(PINHEIRO, 2004, p. 39-41). O reconhecimento dessa situação levou os governos posteriores a buscarem gradualmente corrigir o americanismo de Castelo, reincorporando aos poucos elementos do globalismo em uma visão mais realista de como tentar garantir os objetivos do desenvolvimento nacional. Assim, já os governos seguintes de Costa e Silva e Médici apontaram para o rompimento do alinhamento quase automático de Castelo, preconizando alguns elementos do pragmatismo que seria mais claramente evidenciado na gestão Geisel. (LIMA E MOURA, 1982, p. 349)

Segundo Pinheiro (2004, p. 40-41), apesar de manter o alinhamento com o Ocidente,a "diplomacia da prosperidade" de Costa e Silva foi reincorporando o eixo Norte-Sul como um elemento de definição de políticas, com a busca pela autonomia e pelo desenvolvimento substituindo o confronto Leste-Oeste pelo Norte-Sul e definindo 
o Brasil como nação do Terceiro Mundo, e não apenas do Ocidente. É importante ressalvar que, conforme Martins (1975), ainda se visava à colaboração externa para o desenvolvimento, só que agora por meio de uma atuação cooperativa e conjunta com o Terceiro Mundo. Diante do pequeno interesse demonstrado pelos Estados Unidos no desenvolvimento brasileiro, a "diplomacia da prosperidade" defendeu a integração latino-americana, independente dos Estados Unidos. Assim, o diplomata Azeredo da Silveira, chefe da delegação brasileira, criticou nos fóruns multilaterais a estrutura internacional desigual e as políticas comerciais discriminatórias dos países avançados, defendendo a reforma da estrutura de poder mundial e os interesses do Terceiro Mundo, de tal modo que em 1968 o Brasil foi eleito líder do G77, o grupo dos países em desenvolvimento. (MARTINS, 1975, p. 72-74)

No entanto, essa solidariedade terceiro-mundista e o multilateralismo foram deixados de lado na gestão Médici, que apesar de manter o pragmatismo e o desenvolvimentismo na condução das relações internacionais, voltou a adotar 0 bilateralismo e a buscar a aproximação com os Estados Unidos. Com um projeto de "Brasil potência" que visava o ingresso do país no Primeiro Mundo, criou-se a "diplomacia do interesse nacional" que buscou reaproximar-se da potência norteamericana ao mesmo tempo em que criticava o congelamento da estrutura de poder mundial e os desequilíbrios do comércio e finanças internacionais, tomando algumas decisões em contrariedade a Washington, como a recusa a assinar o Tratado de NãoProliferação Nuclear, a construção de uma indústria armamentista nacional e a ampliação do mar territorial brasileiro. (MARTINS, 1975, p. 82-89)

Conforme Martins (1975, p. 88-89), mesmo com as divergências com os Estados Unidos aumentando, especialmente no plano econômico (acerca do comércio e financiamentos internacionais), mantinha-se o alinhamento, em um frágil equilíbrio mascarado pelo bom desempenho econômico mundial e nacional. Porém, em meados dos anos 1970, o Primeiro Choque do Petróleo atingiu profundamente as economias importadoras de petróleo (como a brasileira, que importava quase todo o petróleo consumido), o protecionismo comercial se generalizou no mundo e o sistema financeiro de Bretton Woods foi destruído com o fim da paridade ouro-dólar e as desvalorizações do dólar, precipitando o fim do Milagre Econômico de 1968-1974.

Sinalizava-se assim a erosão da ordem norte-americana pós-Segunda Guerra Mundial: conforme Arrighi (1994, p. 308-315), os anos de 1950 e 1960 haviam vivido um extraordinário crescimento do comércio e da produção mundial sob liderança dos 
Estados Unidos,cuja continuação nos anos 1970 foi, no entanto, prejudicada pela intensificação da competição entre multinacionais norte-americanas, europeias e japonesas. Além de provocar a alta mundial dos preços de insumos, exacerbada pelos choques do petróleo, essa competição contraiu significativamente os lucros empresariais, levando à transferência do capital das esferas produtivas para as financeiras e dando início a uma verdadeira "revolução financeira".

Como resultado, o autor aponta que mudanças fundamentais começaram a ocorrer na estrutura de poder internacional: o sistema de alianças começou a enfraquecer, houve declínio relativo do poderio dos Estados Unidos ante o fortalecimento da Europa Ocidental e do Japão, os impérios coloniais foram liquidados e potências intermediárias começaram a surgir. Isto é, foi um processo de diversificação do centro da economia-mundo capitalista após quase um quarto de século de domínio hegemônico norte-americano, abrindo alternativas políticas e econômicas para o Brasil, o que aumentou a sua capacidade de barganha perante os Estados Unidos.(ARRIGHI, 1994, p. 330-332)

Em paralelo, a liquidez internacional abundava nos mercados financeiros, buscando ao redor do mundo oportunidades de aplicação para seus fartos recursos. Assim, as necessidades da industrialização brasileira encontraram quem as financiasse, com o crescimento econômico sendo sustentada por meio de forte endividamento externo, cuja contrapartida foi a necessidade crescente de divisas para o pagamento do serviço da dívida. A essa altura, o país já havia consolidado uma indústria de bens intermediários e de capital, o que favoreceu a reincorporação do incentivo às exportações ao modelo de desenvolvimento, mas dessa vez de manufaturados produzidos no país. Assim, como nota Visentini (2008, pp 48-50) um viés exportador de manufaturados foi adicionado ao plano de industrialização e a política externa tornou-se estratégica para essa nova orientação.

Em suma, a nova realidade econômica do país exigia uma nova política externa: “o capitalismo brasileiro atingira um nível de desenvolvimento que gerava um alto grau de inserção mundial" (VISENTINI, 2008, p. 51). Na medida em que a diversificação do centro capitalista nos anos 1970 significou a abertura de alternativas para o Brasil, aumentando sua capacidade de barganha inclusive perante os Estados Unidos, e o modelo político-econômico nacional demandava melhores condições para avançar a industrialização e meios de poder para tornar o país uma potência emergente, o chanceler do governo Geisel, Lima e Moura(1982, p. 352) apontam que o chanceler 
Azeredo da Silveira encontrou os elementos necessários para desenvolver nesse período a política externa que ficou conhecida como "pragmatismo responsável".

Para Lima e Moura (1982, p. 349), a melhor definição da política externa desse período deve ser buscada nas formulações do chanceler de Geisel:

as formulações mais explícitas do que hoje chamamos de política pragmática foram elaboradas entre 1974-1978, na gestão do chanceler Azeredo da Silveira. Depois de 1978, podem-se constatar mudanças de ênfase, estilo e até mesmo de orientação, mas os componentes básicos do pragmatismo permaneceram os mesmos.

Nesse sentido, conforme Fonseca (1998), Azeredo da Silveira deixou em seus discursos importantes pronunciamentos da sua interpretação sobre o que deveria caracterizar a política externa brasileira e qual deve ser o seu papel e atuação:

num mundo em constante mutação, não há coincidências permanentes nem divergências perenes. Nessas condições, não pode haver alinhamentos automáticos [...]. O que devemos buscar em cada momento é explorar as faixas de coincidência que temos em cada um dos países, buscando ao mesmo tempo reduzir as áreas de divergência ou de confrontação. Essa atitude pragmática é a essência mesma da atividade diplomática (Chanceler Silveira, Discurso na ESG em 1974, apud FONSECA, 1998, p. 321).

Assim, o "pragmatismo responsável” buscou, com fins econômicos, aproximarse dos países europeus, árabes, africanos e socialistas:

Superava-se assim, o princípio de fronteiras ideológicas que, desde Castelo Branco, limitava as opções diplomáticas brasileiras. Com Geisel, a política externa finalmente se libertava da camisa-de-força ideológica que dificultara, quando não impedira, a diversificação das relações do Brasil. Finalmente, retomava-se a busca de autonomia pelo afastamento do centro hegemônico e pela aproximação da Europa Ocidental e dos países subdesenvolvidos da Ásia, África e América Latina. (PINHEIRO, 2004, p. 45-46).

Em paralelo, Pinheiro (2004, p. 46-52) aponta que as demandas do desenvolvimento industrial forneceram subsídios para fundamentar as reivindicações do Brasil nas arenas internacionais por um tratamento comercial diferenciado aos países em desenvolvimento, pela abertura de novos mercados e pela cooperação econômica Sul-Sul.Ou seja, na interpretação da autora, houve um claro posicionamento brasileiro alinhado como os interesses do Terceiro Mundo, pelo qual o pragmatismo se definiu em posição contrária à relação especial e infrutífera com Washington, enfatizando o "não alinhamento automático" e evoluindo para uma relação bilateral cada vez mais difícil e complexa. 
Em suma, de certa forma, pode-se dizer que durante todos esses anos houve uma alternância entre o paradigma americanista, em que a percepção de modelo políticoeconômico adequado aos interesses nacionais previa uma relação privilegiada com os Estados Unidos, em que este apoiar o projeto de desenvolvimento brasileiro; e o globalista, em que se buscou diversificar as parcerias internacionais como forma de ampliar as opções e negociar as melhores alternativas para a economia brasileira. $\mathrm{Na}$ realidade, pareceu haver uma linha de transição permeando essa alternância de paradigmas, partindo do alinhamento automático aos Estados Unidos em direção a um crescente pragmatismo na identificação de oportunidades no ambiente internacional favoráveis ao desenvolvimento nacional e à maior autonomia externa do país.

Tendo em vista as hipóteses já aventadas nessa dissertação, parece-nos que esse movimento de transição foi reflexo do conjunto de transformações estruturais que envolveu o país e o sistema de poder internacional que o abarca ao longo do período estudado, conjugado à dinâmica dos jogos de interesses externos e internos ao Brasil. Nesse sentido, para além da transformação estrutural da economia-mundo capitalista, com a diversificação do horizonte internacional de focos de dinamismo econômico alternativos ao protagonismo norte-americano, houve também a própria reestruturação sócio produtiva nacional em direção a uma economia industrializada e de maior grau de complexidade. No conjunto, essas transformações significaram um novo tipo de inserção do país na hierarquia da economia-mundo capitalista, assumindo um novo papel de exportador de manufaturados e reformulando seus canais de dependência com o sistema.

Destarte, a alternância entre os paradigmas americanista e globalista, com progressiva transição do primeiro ao segundo, ocorreu levando em conta o peso da conjuntura externa, da transformação da estrutura produtiva nacional e dos jogos de poder e interesses envolvidos. Assim se explicou o americanismo herdado da Segunda Guerra Mundial, o seu enfraquecimento gradual com a "barganha nacionalista" do segundo governo Vargas e a sua substituição pelo globalismo da "política externa independente" dos governos Jânio Quadros e João Goulart; o seu breve retorno com o golpe militar e a gestão de Castelo Branco, para novamente ser paulatinamente atenuado pelos governos Costa e Silva e Médici até a sua nova substituição pelo globalismo do “pragmatismo responsável”do governo Geisel.

Portanto, tendo em vista a transformação da estrutura produtiva brasileira e da própria economia-mundo capitalista, e a disputa entre grupos de interesse domésticos e 
estrangeiros, houve uma alternância de prioridades da política externa brasileira ao longo de todo esse período, que oscilou entre o alinhamento aos Estados Unidos e o multilateralismo. Cabe ressaltar ainda a ação nesse processo de transição entre paradigmas,e o papel sobre a política externa brasileira, de outras instituições governamentais envolvidas no projeto de desenvolvimento brasileiro, como o Ministério da Fazenda e seus órgãos, dos quais se destacam o BNDE e o BCB, cujas atuações serão abordadas na segunda parte desta dissertação.

\subsection{SÍNTESE: A POLITICA EXTERNA COMO INSTRUMENTO DO DESENVOLVIMENTO}

A despeito das diferenças nos enfoques e nos objetivos das análises, tanto os autores abordados que pensaram a respeito do processo de industrialização, quanto a política externa brasileira da segunda metade do século XX, têm como ponto de contato a questão comum do subdesenvolvimento e da redução da dependência brasileira em relação aos centros de dinamismo capitalista ou, alternativamente, do aumento da sua autonomia nas questões externas e da reforma da estrutura de poder político-econômico internacional. De modo simplificado, enquanto os primeiros se debruçaram sobre a adequação da industrialização enquanto meio para superar o subdesenvolvimento e os seus resultados, a política externa resultou das disputas entre grupos políticoeconômicos nacionais com interesses e leituras diferenciadas sobre a posição internacional da economia brasileira e a industrialização, tendo em vista o quadro mais amplo de alteração das estruturas sistêmicas mundiais.

$\mathrm{Na}$ realidade, os elementos de proximidade e distanciamento entre essas duas esferas vão mais além, na medida em que não constituíam grupos isolados de discussão e pensamento sobre as realidades brasileiras, havendo diálogos e trocas de ideias entre elas. Assim, os diagnósticos de Prado Jr., Furtado e Rangel sobre a economia brasileira, sua posição periférica como nação dependente e seu processo de industrialização ecoavam nos agentes e instituições governamentais atuantes na política de inserção internacional da economia brasileira, como o MRE e o Ministério da Fazenda. Inclusive, nos casos de Furtado e Rangel, sendo eles mesmos servidores públicos de carreira, muitas vezes ocupantes de cargos estratégicos no governo, sua influência nas 
ações e projetos de política de inserção internacional da economia brasileira do governo não podem ser desprezadas.

Nesse sentido, as ideias veiculadas pelos primeiros contribuíram para a disseminação, entre os anos 1930 e 1980, da importância do planejamento estratégico estatal na condução da industrialização como meio para alcançar o desenvolvimento, além de denunciarem a posição internacional do Brasil como país dependente e subdesenvolvido, membro da periferia de uma estrutura capitalista desigual e tendente a exacerbar os desequilíbrios entre países.Em diversas ocasiões, atuaram em conjunto com o próprio corpo burocrático do governo, cuidando de realizar diagnósticos da realidade brasileira dentro do sistema internacional, desenvolver propostas de atuação e elaborar estratégias de apoio ao desenvolvimento.

Por fim, cabe destacar a centralidade do Estado, que conforme a interpretação de Rangel,foi um agente promotor do progresso industrial por meio da gestão de investimentos, do controle do comércio exterior e do mercado de divisas, intermediando as relações entre as formas econômicas "internas" e "externas" da economia brasileira, de modo a possibilitar a instalação de uma estrutura industrial verticalizada e diversificada. Boa parte desse papel ficou centrado em instituições como o MRE e o Ministério da Fazenda, que acabaram consubstanciando-se como importantes agentes do desenvolvimento nacional. Apesar de ter oscilado entre a escolha de dois caminhos para o desenvolvimento, um favorável à associação aos interesses norte-americanos, e outro tendente à diversificação pragmática das relações com outros países, ou ainda uma combinação entre os dois extremos, o caminho almejado pela diplomacia brasileira foi, em maior ou menor medida, o desenvolvimento econômico, a redução e eliminação das assimetrias internacionais e o aumento do espaço de autonomia nacional. 


\section{PARTE II \\ O BRASIL NO CICLO SISTÊMICO DE ACUMULAÇÃO CAPITALISTA AMERICANO: \\ O PAPEL DA POLÍTICA EXTERNA E DA POLÍTICA ECONÔMICA}




\section{CAPÍTULO 1 \\ O CICLO SISTÊMICO DE ACUMULAÇÃO CAPITALISTA AMERICANO E A GEOPOLÍTICA DA GUERRA FRIA}

\subsection{INTRODUÇÃO}

A avaliação da inserção internacional da economia brasileira requer abordar a evolução das condições do quadro sistêmico que a abarca, especialmente no que diz respeito à dinâmica de transformações da economia-mundo capitalista e suas implicações para o país. Assim sendo, este capítulo objetiva delinear elementos de insumo para a análise a ser desenvolvida nos capítulos que o sucedem, de modo a identificar categorias instrumentais que nos permitam abarcar o contexto internacional vivido pela economia brasileira durante o período estudado e as suas consequências para o seu padrão de inserção internacional.

Com estes fins, optou-se por seguir a proposta de Arrighi (1994), para quem a história do capitalismo se desenrola por uma sucessão de ciclos sistêmicos de acumulação. Nessa visão, conforme já visto anteriormente, cada ciclo diferenciou-se dos ciclos passados pela liderança de um novo centro de poderio político e econômico que, de modo diverso do anterior, promoveu e difundiu o seu próprio regime de acumulação capitalista.

Em específico, o intervalo entre 1945 e 1980, período proposto da pesquisa, foi dos anos de auge e início de um suposto declínio do quarto ciclo sistêmico de acumulação capitalista, chamado por Arrighi (1994) de o "longo século XX", em que os Estados Unidos se consolidaram como centro hegemônico da economia-mundo capitalista.Segundo o autor, o "longo século XX" poderia, por ora, ser dividido em três fases: a expansão financeira do final do século XIX, quando as estruturas do ciclo sistêmico anterior, centrado no Reino Unido, foram destruídas e substituídas por novas formas originadas nos Estados Unidos; a expansão material internacional dos anos 1950 e 1960 sob a liderança norte-americana; e a expansão financeira iniciada nos anos 1970, “em cujo decurso as estruturas do já 'antigo' regime norte-americano vêm sendo destruídas, com a criação - supõe-se - de um ‘novo’ regime”. (ARRIGHI, 1994, p. ix) 
Cabe ponderar aqui que Arrighi (1994) não se refere propriamente a um "esmorecimento" da hegemonia norte-americana, mas ao enfraquecimento do modelo de acumulação consolidado pelos Estados Unidos durante os anos 1950 e 1960. Inclusive, ao desenvolver suas ideias, o autor busca compreender como Washington logrou permanecer no centro da economia-mundo capitalista por meio da redefinição de seus meios de poder, desenvolvendo novas forças no cenário internacional, ao mesmo tempo em que as contradições de seu modelo de acumulação se intensificavam, principalmente a partir dos anos 1970. Embora não ofereça respostas definitivas impossíveis tendo em vista serem processos em decurso quando do desenvolvimento de sua pesquisa -, o autor chega a aventar duas possibilidades: a formação de um novo tipo de poder ou de "superioridade de força" pelos Estados Unidos, ou "o começo do fim da superioridade de força sobre o qual se erigiram, nos últimos quinhentos anos, os destinos capitalistas do Ocidente" (ARRIGHI, 1994, p. 23).

Prenúncio ou não do fim do ciclo sistêmico de acumulação capitalista norteamericano, discussão fundamental mas que foge ao escopo deste trabalho, o fato é que houve uma expressiva expansão das formas financeiras do capital nos anos 1970, com características semelhantes às fases de expansão financeira dos ciclos de acumulação anteriores identificadas por Arrighi (1994), e que teve importantes implicações para a economia brasileira e sua forma de inserção na economia-mundo capitalista.

Visando a complementar este arcabouço teórico, para além das contribuições essenciais de Arrighi $(1994,1998)$ também foram utilizadas as ideias de Dicken (1998), Eichengreen (2012), Frieden (2008), Gilpin (2000) e Kindleberger (1990) sobre a evolução e implicações do regime de acumulação norte-americano, em especial as características do modelo arquitetado a partir dos acordos de Bretton Woods e da criação da Guerra Fria. No que diz respeito às consequências deste regime para a periferia da economia-mundo capitalista, é de especial importância o ensaio de Prebisch que foi consagrado sobre o título de "Manifesto Latino-Americano" (1949), em cujas páginas foram expressos os fundamentos de muitos dos projetos de industrialização implementados na América Latina no período.

A estrutura deste capítulo é composta por três seções, cada uma destinada a abordar uma das três fases do ciclo sistêmico de acumulação norte-americano identificadas por Arrighi (1994) - ascensão, auge e início do "declínio" do regime centrado nos Estados Unidos - de modo a identificar suas implicações para a economia brasileira, além da introdução e da conclusão. 


\subsection{DE LONDRES A WASHINGTON: DUAS DEPRESSÕES E DUAS GUERRAS MUNDIAIS}

A passagem do ciclo sistêmico de acumulação britânico ao norte-americano não se deu de forma automática e imediata, mas se estendeu por quase meio século desde o final do século XIX até o término da Segunda Guerra Mundial. Também não foi suave ou sem traumas, tendo sido marcada por duas grandes depressões e duas guerras de alcance mundial. Suas implicações se propagaram por toda a economia-mundo capitalista, do seu centro de dinamismo econômico até as várias periferias, alterando de modo fundamental as suas estruturas socioeconômicas e relações inter-regionais.

Em especial, para alguns países da América Latina, entre eles o Brasil, esta transição significou a superação do "velho" esquema da divisão internacional do trabalho do século XIX, em que lhes cabia fornecer alimentos e insumos para o centro industrializado e a este último suprir as necessidades de manufaturados dos primeiros, em direção a um novo papel como países industrializados porém ainda dependentes do centro de dinamismo capitalista do sistema. Nas palavras de Prebisch (1949): "duas guerras no curso de uma geração, e uma profunda crise econômica entre elas, demonstraram aos países da América Latina, suas possibilidades apontando-lhes, positivamente, o caminho da atividade industrial" (p. 47).

A primeira expressão da crise do regime de acumulação britânico foi a Grande Depressão de 1873-1896 que, conforme Arrighi (1994, p. 279-281), decorreu de uma intensa competição intercapitalista gerada pela fase de expansão material britânica, quando os lucros começaram a se reduzir e as oportunidades de bons negócios rarearam. A solução encontrada pelos grupos capitalistas para superar a estagnação foi o deslocamento dessa competição para o âmbito interestatal, buscando alianças junto aos Estados europeus na tentativa de vencer a acirrada concorrência e reavivar a acumulação de capital por meio do uso da força político-econômica. No entanto, "a cura revelou-se pior que a doença" (ARRIGHI, 1994, p. 277), com a competição interestatal transformando-se em uma escalada armamentista entre aspirantes europeus à potência hegemônica que culminou na Primeira Guerra Mundial.

Embora o Reino Unido tenha saído vencedor da Primeira Guerra, Arrighi (1994, p. 279-281) considera que o conflito bélico foi o ponto decisivo da sua derrocada. Para o autor, a Primeira Guerra impulsionou a destruição de um fundamento crucial do 
regime de acumulação britânico: o seu superávit externo com a Índia, com os Estados Unidos e com a Europa continental. Esses países forneciam bens primários e insumos às indústrias britânicas,consumiam seus manufaturados e se financiavam em Londres.O conflito lançou as sementes da independência indiana, enfraqueceu os mercados europeus e abriu espaço para os Estados Unidos alterarem seu déficit comercial e saldarem suas dívidas com o Reino Unido por meio do fornecimento dos insumos demandados pela Tríplice Entente em seu esforço de guerra.

Nas palavras de Kindleberger: "a Primeira Guerra Mundial mudou completamente a posição dos Estados Unidos na economia mundial" (1990, p. 212). De 1914 a 1917 o país conseguiu transformar-se de devedor em credor internacional, expandindo seus empréstimos aos países europeus por meio da consolidação da estrutura monetária baseada no Sistema do Federal Reserve (FED) e da obtenção de expressivos superávits comerciais. Após a guerra, os Estados Unidos expandiram ainda mais sua influência na Europa, especialmente nas questões financeiras e monetárias, seja por meio de empréstimos entre países, seja por meio da atuação do Sistema FED para apoiar os bancos centrais europeus.Desse modo, os Estados Unidos conseguiram equiparar-se em termos monetários ao Reino Unido, com o dólar transformando-se em moeda de reserva internacional ao lado da libra esterlina, e parte do controle da liquidez mundial passando de Londres para Washington. (KINDLEBERGER, 1990, p.211-214)

Em paralelo, Kindleberger (1990, p. 214) aponta que a economia norteamericana engatara em um ciclo de dinamização crescente, com a sua produtividade crescendo acima da do resto do mundo e Washington aumentando ainda mais suas vantagens no comércio exterior por meio da imposição de pesadas tarifas de proteção às suas “indústrias infantes”. Nesse sentido, o autor destaca ainda a revolução corporativa representada pelas linhas de montagem desenvolvidas por Henry Ford, que promoveram uma significativa expansão e barateamento da produção norte-americana de manufaturas.

Mesmo assim, apesar da evidente ascensão dos Estados Unidos e do gradual enfraquecimento do Reino Unido, Londres permanecia na liderança do sistema monetário mundial, possuindo as maiores reservas de ouro do mundo. Além disso, Arrighi (1994) aponta que a comunidade financeira norte-americana mantinha-se ideologicamente subordinada à Londres, apoiando as tentativas britânicas de reimpor o sistema monetário anterior (o padrão ouro) e assim manter o controle da economia- 
mundo capitalista ${ }^{67}$. Na realidade, as tentativas de restaurar o padrão ouro foram apoiadas por grande parte dos governos ocidentais, que partilhavam de "convicção de que somente o restabelecimento do sistema monetário mundial pré-1914, 'desta vez sobre bases sólidas', poderia restaurar a paz e a prosperidade" (ARRIGHI, 1994, p. 281).

Entretanto, tal sistema significava o retorno às moedas pareadas ao ouro e ao livre comércio, em um contexto de fuga generalizada de capitais e economias estagnadas.Além de alimentar fluxos de capitais especulativos, as tentativas de restabelecer o padrão ouro significaram políticas fiscais e monetárias restritivas que pioraram a contração econômica. Assim, o resultado foi o estrangulamento do sistema monetário e do comércio internacional, transformando a estagnação dos anos 1920 na Grande Depressão de 1930: "esse esforço conjunto, em vez de ressuscitar o sistema monetário mundial pré-1914, precipitou a sua crise terminal" (ARRIGHI, 1994, p. $281)^{68}$.

Além da crise das finanças mundiais, iniciou-se uma corrida de medidas protecionistas, desvalorizações cambiais e controles de capitais por diversos países, na tentativa de salvaguardar suas economias nacionais. Um exemplo famoso foi a tarifa Smoot-Hawley imposta pelos Estados Unidos em 1930, que elevou tarifas aduaneiras desde produtos agrícolas até manufaturados, ajudando a impulsionar reações protecionistas pelo mundo: "a tarifa Smoot-Hawley foi o principal impulso para iniciar uma Guerra de retaliações tarifárias [...] O comércio mundial encolheu em uma espiral decrescente" (KINDLEBERGER, 1990, p. 215).

Essas consequências foram acompanhadas ainda, aponta Arrighi (1994, p. 288), pela substituição da Liga das Nações pelos impérios autárquicos, pelo nazismo alemão, pelos planos quinquenais soviéticos e pelo Estado keynesiano do New Deal ${ }^{69}$. Segundo o autor, o objetivo principal do New Deal proposto por Roosevelt era libertar a política

\footnotetext{
${ }^{67}$ Conforme Cohen (2006, p. 30-32), o "poder monetário" é um importante meio de poder estatal, pois o monopólio da governança monetária internacional (o controle sobre a oferta e a circulação da moeda de reserva mundial) é um poderoso símbolo de hegemonia de um país, além de ser uma fonte de receitas para seu governo (pela seigniorage ou "imposto inflacionário", que são emissões de moeda ao custo da perda de poder de compra dos demais países) e de expressar sua autonomia perante influências ou restrições monetárias externas.

${ }^{68} \mathrm{Em}$ particular, o envolvimento das altas finanças nova-iorquinas no projeto de restauração do padrão ouro trouxe uma febre especulativa à Wall Street, culminando na quebra de 1929 e a subsequente depressão nos Estados Unidos (ARRIGHI, 1996, p. 282).

${ }^{69}$ Em nossa visão, devem ser destacados ainda, como será desenvolvido adiante, o impulso aos processos de industrialização dos países latino-americanos em resposta ao estrangulamento externo e o desenvolvimento das formulações acerca da lógica centro-periferia e do papel do Estado na promoção da industrialização na periferia da economia-mundo capitalista.
} 
econômica dos princípios da moeda forte defendidos por Wall Street e Londres, e direcioná-la à recuperação econômica nacional. Além de promover o aumento dos gastos estatais para estimular a economia, Roosevelt rompeu a conversibilidade do dólar ao ouro, desvalorizou a moeda e regulamentou a atividade dos bancos e demais instituições financeiras.

A despeito das intervenções estatais na economia, o autor aponta que a recuperação total só foi possibilitada com o advento da Segunda Guerra Mundial, quando o incremento de poder norte-americano foi ainda maior do que na Primeira Guerra. Em sua avaliação, o confronto armado "reproduziu um padrão repetitivo da economia mundial capitalista" (ARRIGHI, 1994, p. 283), em que a substituição de um regime de acumulação em escala mundial por outro se deu por meio de sérios processos e conflitos geopolíticos que envolveram a destruição das bases anteriores. Atuando como fornecedor dos Aliados em seu esforço de guerra, os Estados Unidos auferiram enormes superávits que o tornaram quase monopolista da liquidez mundial, concentrando as reservas de ouro internacionais e difundindo o uso do dólar pelo mundo. Assim, a Segunda Guerra representou o término do processo que se iniciara no fim do século XIX, com a substituição definitiva do ciclo de acumulação britânico pelo norte-americano.(ARRIGHI, 1994, p. 284)

Para a América Latina - e o Brasil -, essas crises que afligiram a economiamundo capitalista durante a transição de Londres a Washington tiveram importantes implicações que impulsionaram a transformação de suas estruturas produtivas e da natureza de suas relações com o sistema. As dificuldades do comércio internacional comprometeram seriamente a demanda mundial por primários, de cujas exportações dependiam as nações latino-americanas,reduzindo drasticamente sua capacidade de importar e gerando sérias crises de solvência externa. Evidenciava-se, assim, o seu elevado grau de dependência e vulnerabilidade externa: não só dos mercados consumidores de sua produção, mas também das divisas necessárias para importações de manufaturados para consumo interno.

Diante da insustentabilidade dessa situação, Love (1996, p. 212-214) aponta que a defesa industrialista foi crescendo e se aprimorando na América Latina, assim como a intervenção estatal em prol das indústrias nacionais. Segundo o autor, até 1949 a industrialização era no geral defendida por muitos governos latino-americanos sem embasamento teórico, de forma limitada e inconsistente.Mesmo assim, a industrialização avançara significativamente em alguns países latino-americanos já nos 
anos 1920, entre eles o Brasil, e ganhou forte impulso com o estrangulamento externo gerado pela Grande Depressão de 1929.

Ao fim da Segunda Guerra, o autor avalia que a industrialização na América Latina já havia avançado consideravelmente, em um processo que ficou conhecido como "industrialização por substituição de importações", porém sem ter ainda uma teoria que o legitimasse. Em suas palavras: “a industrialização na América Latina foi fato antes de ser política, e política antes de ser teoria” (LOVE, 1996, p. 209).

Tal teoria veio a ser desenvolvida pela Cepal após a Segunda Guerra, tendo como pontapé inicial o "Manifesto Latino-Americano" de Prebisch (1949) ${ }^{70}$, que deu substância teórica e projeto intelectual aos processos de industrialização. Esse famoso ensaio, na realidade intitulado "O desenvolvimento econômico da América Latina e seus principais problemas", lançou os fundamentos do núcleo básico da teoria cepalina do subdesenvolvimento latino-americano. Nesse texto, Prebisch sintetiza muitas das suas ideias elaboradas durante os anos 1930 e 1940, em que ele analisou a realidade dependente da periferia latino-americana em decorrência de seu papel na divisão internacional do trabalho como região exportadora de primários e importadora de manufaturados.

Como diagnóstico, o autor avaliou não haver espaço para o desenvolvimento econômico dos países latino-americanos na antiga lógica "centro-periferia", defendendo como solução a transformação de suas estruturas produtivas em direção à industrialização. Isso significaria a promoção de um "crescimento voltado para dentro", permitindo a redefinição do padrão de dependência econômica, a redução da vulnerabilidade externa e a internalização do controle dos rumos das economias latinoamericanas.

Sumariamente, Prebisch(1949, p. 54-56) aponta que a divisão internacional do trabalho estruturada em "centro-periferia", com o centro especializado na produção de manufaturados e a periferia na de primários, não trouxe os ganhos esperados da especialização produtiva para esta última, mas sim uma profunda dependência e fragilidade externa. Em teoria, os ganhos do progresso técnico no centro, superiores aos da periferia, deveriam promover a redução dos preços dos manufaturados, o que tornaria os termos de troca favoráveis aos bens primários (e à periferia).

\footnotetext{
${ }^{70}$ Esse ensaio foi usado como introdução ao primeiro "Estudo Econômico da América Latina" da Cepal (1950).
} 
No entanto, de 1870 até 1939 essa relação de preços evoluiu contra os bens primários: os preços de manufaturados não declinaram com o aumento da produtividade, que na realidade se converteu em aumentos da remuneração do capital e do trabalho nos países industrializados, permitindo a concentração de uma enorme capacidade de poupança nesses países. Em paralelo, os ganhos do progresso técnico que, apesar de em menor grau, também ocorriam na periferia, eram repassados aos preços dos bens primários, reduzindo-os sem se converterem em ganhos salariais.Ou seja, enquanto "os centros retiveram integralmente o fruto do progresso técnico de sua indústria, os países da periferia traspassaram-lhes uma parte do fruto do seu próprio progresso técnico" (PREBISCH, 1949, p. 56).

O excedente gerado no centro não era distribuído, mas o gerado na periferia era. Essa dinâmica desfavorável à periferia era agravada pelos ciclos econômicos propagados a partir do centro: nas fases prósperas, ambos os preços de agrícolas e manufaturados subiam; porém nas crises, como boa parte do aumento dos preços de manufaturados fora repassada para os salários no centro, a sua redução de preços era dificultada - o que não ocorria na periferia. Em consequência, os preços de primários oscilavam mais intensa e rapidamente que os de manufaturados, caindo mais nas crises e penalizando mais a periferia do que o centro. (PREBISCH, 1949, p. 58-59)

Para o autor, a industrialização era a solução que permitiria a esses países romperem essa dinâmica desfavorável e alcançar maior autonomia na condução de suas próprias economias e desenvolvimento. No entanto, assim como Furtado (1974), Prebisch (1949) destaca a existência nos países latino-americanos de "uma tendência muito acentuada para certas modalidades de consumo, que muitas vezes resultam incompatíveis com um alto grau de capitalização" (p. 51-52). Em sua visão, o problema da reduzida poupança latino-americana não está no consumo das massas, que no geral é irrisório, mas no consumo de supérfluos importados pelos setores ricos da coletividade. Por isso, além do capital externo, ele ressalta ser necessária a priorização das importações em favor de bens de capital e insumos para a industrialização. (PREBISCH, 1949, p. 72-74)

Nesse sentido, a intervenção governamental se configura como central para garantir essas ações e programar a transformação da economia. Assim, Prebisch (1949) pondera que o projeto de industrialização, tendo em vista a realidade das estruturas produtivas da América Latina, deveria ser acompanhado do controle das importações e 
do planejamento estratégico estatal na gestão e controle das atividades econômicas, visando garantir a sua transformação e desenvolvimento.

Portanto, os dois conflitos geopolíticos e as duas depressões econômicas que marcaram a transição de Londres a Washington como centro dinâmico da economiamundo capitalista significaram, além da substituição do regime de acumulação britânico pelo norte-americano, o início da transformação de algumas estruturas produtivas latino-americanas em direção à industrialização,na tentativa de reduzir sua vulnerabilidade e dependência externa.Em particular, destaca-se a criação da Cepal a partir do estudo dessas transformações e da natureza das relações centro-periferia, provendo as justificativas teóricas que apoiaram a programação estatal em prol da industrialização que marcou a trajetória de muitos países latino-americanos na segunda metade do século XX.

\subsection{BRETTON WOODS E A GUERRA FRIA: O AUGE DO CAPITALISMO DAS TRANSNACIONAIS NORTE-AMERICANAS}

Durante a Segunda Guerra Mundial, os Estados Unidos lograram concentrar um expressivo poderio político e econômico no cenário internacional, estabelecendo-se após o seu término como o novo centro hegemônico de um cenário em que as tradicionais potências europeias encontravam-se literalmente destruídas pela guerra. Conforme Arrighi (1994, p. 283), no imediato do pós-guerra esse poderio foi consolidado por meio da construção de uma nova ordem mundial orquestrada a partir de Washington, em que se deu uma concentração de poder sem precedentes por meio do estabelecimento de um novo sistema monetário internacional (os acordos de Bretton Woods) e de um novo sistema de normas de gestão do Estado e da guerra (a Carta de criação da Organização das Nações Unidas), além da demonstração de força militar ocorrida em Hiroshima e Nagasaki.

$\mathrm{Na}$ realidade, esses movimentos estiveram estreitamente relacionados com as necessidades do que Arrighi (1994, p. 303) chamou de "capitalismo de corporações" norte-americano.Originalmente, o autor aponta que esse modelo corporativo surgiu nos Estados Unidos como solução para vencer a intensa competição interempresarial resultante do modelo britânico na virada entre os séculos XIX e XX, substituindo a 
integração horizontal e política de empresas em concorrência (rede de pequenas e médias empresas concorrentes entre si controlada politicamente pelo império britânico) pela integração vertical e empresarial (reunião de diversas etapas do processo produtivo em uma única estrutura corporativa).(ARRIGHI, 1994, p. 248)

A verticalização permitiu uma drástica redução dos custos de planejamento e transação, determinando vantagens competitivas decisivas no processo produtivo que lançaram os fundamentos do novo ciclo de acumulação norte-americano. Durante as duas guerras mundiais, a expansão dessas corporações foi beneficiada pelo "caos sistêmico" que abalou o mundo, e que permitiu, conforme Arrighi (1994, p. 284), uma "concentração e centralização tanto da capacidade produtiva quanto da demanda efetiva" nos Estados Unidos. Nesse contexto, as corporações norte-americanas conseguiram se consolidar e fortalecer em seu mercado doméstico, reunindo condições para expandir suas atividades internacionalmente.

A expansão transnacional das corporações norte-americanas foi um importante meio de penetração dos fundamentos do novo regime centrado nos Estados Unidos em outros países, atuando como "um punhado de 'cavalos de Tróia' nos mercados internos de outros Estados"e facilitando a "centralização, nos Estados Unidos, da liquidez, poder aquisitivo e capacidade produtiva da economia mundial"(ARRIGHI, 1994, p. 304).

Entretanto, o mesmo autor aponta que a situação internacional de destruição e caos sistêmico que se seguiu imediatamente após a Segunda Guerra determinou limites à expansão deste "capitalismo de corporações", restringindo as possibilidades de comércio e investimentos internacionais e a expansão da liquidez mundial. Destarte, fazia-se necessário superar o caos instalado e construir um ambiente internacional mais favorável à continuidade do ciclo de expansão material do capitalismo de corporações norte-americano. Tais objetivos foram perseguidos, essencialmente, por meio de duas frentes: os acordos de Bretton Woods e a "invenção da Guerra Fria”.

Durante a Segunda Guerra, a transferência de recursos e assistência dos Estados Unidos aos Aliados foi condicionada, conforme Kindleberger (1990, p. 218), ao compromisso com um plano de construção de uma nova ordem econômica internacional liderada pelos norte-americanos. Esse plano ficou conhecido pelos acordos de Bretton Woods, que visavam a criação de diversas instituições multilaterais para regular e supervisionar a economia internacional: o Banco Internacional para a Reconstrução e o Desenvolvimento (BIRD) como banco financiador da reconstrução dos países destruídos pela guerra e do desenvolvimento dos países não industrializados; o Fundo 
Monetário Internacional(FMI) como supervisor das taxas cambiais, dos balanços de pagamento e do sistema financeiro; e a Organização Internacional do Comércio (OIT) como reguladora do comércio internacional(KINDLEBERGER, 1990,p.219-220).

Na realidade, como ressalta Frieden (2008, p. 309-311), o objetivo dos acordos de Bretton Woods remetia à liberalização do comércio e dos investimentos com estabilidade monetária, conforme os interesses do capitalismo norte-americano. Nesse sentido, Eichengreen (2012,p.131-132) aponta que os acordos originais de Bretton Woods previam um sistema multilateral presidido pelo FMI para monitorar as taxas de câmbio e os balanços de pagamentos de modo a garantir a estabilidade do sistema, porém prevaleceu um sistema centrado no dólar, ou seja, sob o controle do FED norteamericano. As moedas nacionais eram fixas ao dólar a taxas pré-estabelecidas, e o dólar era conversível por um volume fixo de ouro, com uma margem de flexibilidade para variação para não afligir demasiadamente as economias nacionais. Ao FMI restou o papel de monitorar as taxas de câmbio para penalizar países que provocassem desequilíbrios e prover recursos para garantir o equilíbrio do sistema.

Para o autor, esse "meio-termo" entre a rigidez do padrão-ouro e a volatilidade do câmbio flexível servia bem aos objetivos do livre comércio e, principalmente, das corporações norte-americanas, que seriam beneficiadas pelo restabelecimento das relações de comércio abertas e multilaterais. Os países poderiam alterar o valor de suas moedas em casos de sérios riscos às suas economias, mas no geral mantendo uma estabilidade cambial para estimular o comércio e os investimentos internacionais. $\mathrm{O}$ objetivo do restabelecimento do comércio internacional explicaria, na visão de Eichengreen (2012, p. 138-139), não só a ênfase nas paridades fixas cambiais, mas também a criação do GATT, encarregado de derrubar as barreiras não cambiais ao comércio internacional.

Indo mais além, Arrighi (1994,p. 288) avalia que Bretton Woods significou mais do que meros acordos visando estabilizar paridades entre moedas e fomentar o "liberalismo econômico". Lembrando que os controles aos movimentos de capitais eram permitidos, o autor aponta que estes não eram apenas uma forma de prevenir a ocorrência de carry-trades $^{71}$ especulativos, mas também um meio de garantir a transferência do controle da liquidez mundial das mãos de banqueiros e financistas particulares para as dos governos nacionais. Desse modo, o autor avalia que os acordos

\footnotetext{
${ }^{71}$ Fluxos de capitais buscando se aproveitar do diferencial de juros entre países com taxas de câmbio fixas.
} 
de Bretton Woods facilitaram a transferência do controle dos circuitos monetários e financeiros dos agentes privados para os Estados nacionais e seus bancos centrais:

houve uma grande revolução no agente e no modo de 'produzir' o dinheiro mundial.[...] a "produção" do dinheiro mundial foi assumida por uma rede de organizações governamentais, primordialmente movidas por considerações de bem-estar, segurança e poder - em princípio, o FMI e o Banco Mundial, e na prática, o Sistema da Reserva Federal dos Estados Unidos, agindo em concerto com os bancos centrais dos aliados mais íntimos e mais importantes do país. Assim, o dinheiro mundial tornou-se um subproduto das atividades de gestão do Estado [...] Washington, e não Nova York, confirmou-se como a sede primária da "produção" do dinheiro do mundo.(ARRIGHI, 1994, p. 287-288).

Em consonância a esses movimentos, Arrighi (1994, p. 289) indica que a única forma de redistribuição de liquidez mundial que foi incentivada pelos Estados Unidos nesse período, foram os investimentos diretos estrangeiros de suas empresas transnacionais. Também nesse sentido, Frieden (2008, p. 313-316) aponta que, se o esperado pelos acordos originais era um papel central do BIRD nos empréstimos internacionais de longo prazo para a reconstrução da Europa e Japão e para as demandas dos países em desenvolvimento, o Plano Marshall e os investimentos diretos estrangeiros das transnacionais norte-americanas demonstraram um protagonismo muito maior. E de fato, Kindleberger (1990, p. 224) ainda constata que os empréstimos de bancos internacionais que predominavam antes da Primeira Guerra foram sendo desestimulados pelos controles de capitais de Bretton Woods, assim como a assistência oficial aos países em desenvolvimento foi sendo substituída por investimentos diretos de corporações norte-americanas.

Entretanto, esses elementos ainda não eram suficientes para propiciar a restauração da liquidez internacional e da expansão do comércio e produção mundiais. Desse modo, aproveitando os receios de que forças revolucionárias tomassem o poder na região europeia destruída pela guerra, Arrighi (1994, p. 305) aponta que o presidente norte-americano Henry Truman lançou com sucesso a ideia de uma ameaça de proporções sistêmicas ao "mundo livre ocidental", relacionada às "inclinações supostamente subversivas da outra potência militar, a União Soviética”.Inventou-se assim a Guerra Fria, com os Estados Unidos usando o medo da ameaça comunista como justificativa para um discurso em prol do fortalecimento do capitalismo no "mundo 
livre" sob sua liderança e provendo a fundamentação ideológica para garantir as condições necessárias à expansão de seu "capitalismo de corporações".

Nesse sentido, o Plano Marshall foi um programa de investimentos e assistência norte-americana para a reconstrução da Europa Ocidental e do Japão, visando a transformá-los em "vitrines" do mundo livre e fomentar a expansão internacional do capitalismo norte-americano.Em específico no caso da Europa pretendia-se construir uma "união dos Estados europeus" à semelhança dos Estados Unidos, um mercado de potencial econômico semelhante ao norte-americano. Mesmo assim, Arrighi avalia que, apesar de ter contribuído significativamente para a recuperação do comércio e produção mundiais, os recursos aplicados pelo Plano Marshall ainda não foram suficientes:

A integração europeia e a expansão econômica mundial exigiam uma reciclagem muito mais abrangente da liquidez mundial do que estava implícita no Plano Marshall e em outros programas de assistência. Essa reciclagem mais abrangente acabou por se materializar no mais maciço esforço de rearmamento que o mundo já vira em tempos de paz. [...] somente um esforço desse tipo poderia superar as limitações do Plano Marshall. (ARRIGHI, 1994, p. 306)

Destarte, o autor aponta que, no início da década de 1950, os Estados Unidos voltou-se para uma nova orientação política, fundamentada em um grande esforço de rearmamento norte-americano e europeu como meio de resolver os problemas econômicos enfrentados no pós-guerra. Além de sustentar a demanda para as corporações norte-americanas, os gastos bélicos e a ajuda militar a governos estrangeiros aliados aproximou a Europa Ocidental dos Estados Unidos, facilitando o acesso do último aos mercados europeus.

Os 23 anos entre a Guerra da Coréia e os Acordos de Paris (1950-1973) foram um período de crescentes gastos militares dos Estados Unidos no exterior que proveu "à economia mundial toda a liquidez de que ela precisava para se expandir" (ARRIGHI,1994, p. 307), permitindo o florescimento do comércio e produção mundiais em um ritmo excepcional para os padrões históricos. Para Arrighi (1994), mais que os acordos de Bretton Woods, foi a "invenção" da Guerra Fria que sustentou o auge do ciclo de acumulação norte-americano nos anos 1950 e 1960, por meio do "mais maciço esforço de rearmamento que o mundo já vira em tempos de paz” (p. 305-306). Os gastos envolvidos na cisão ideológica de um mundo bipolar proveram importantes estímulos à economia mundial e ao restabelecimento da liquidez internacional, criando as condições para expansão transnacional das corporações norte-americanas, cujos investimentos 
diretos estrangeiros acompanharam esse movimento de reflorescimento econômico mundial dos anos 1950 e 1960.

Essas características do ciclo de acumulação norte-americano tiveram importantes implicações para a periferia da economia-mundo capitalista. No caso dos países latino-americanos, Prebisch (1949) avalia que a natureza do novo "centro cíclico norte-americano" veio a agravar a sua vulnerabilidade externa. Em sua visão, os Estados Unidos, de forma diversa ao Reino Unido, tendiam a reduzir suas importações por meio do seu acelerado crescimento de produtividade e tradicional protecionismo comercial, e após a Segunda Guerra passaram ainda a restringir a saída de capitais que não fosse pelo Plano Marshall ou por suas transnacionais, conservando o ouro que atraía e sufocando o desenvolvimento das regiões periféricas. (PREBISCH, 1949, p. 63-64)

Em consequência, além da tendência ao desequilíbrio comercial entre a América Latina e o novo centro (enquanto este tendia a reduzir suas importações, aquela tendia a aumentá-las, seja para a aquisição dos bens de capital necessários à industrialização, seja para a manutenção da importação dos bens de consumo manufaturados), os países latino-americanos tinham dificuldades em obter apoio financeiro do governo norteamericano e de instituições multilaterais como o BIRD e o FMI para enfrentar a escassez de dólares necessários para atender suas demandas por importações.

Tendo em vista a realidade diversa das economias latino-americanas, Prebisch (1949,p.84-87) lembra que os ciclos manifestam-se de formas diversas no centro e na periferia: nos centros, o investimento é o elemento dinâmico da sua evolução cíclica (a renda varia com o investimento), enquanto que na periferia, o elemento dinâmico são as exportações. E, ao contrário dos investimentos no centro, as exportações não estão sobre controle da periferia, dependendo de fatores exógenos.Destarte, mesmo que políticas anticíclicas fossem executadas de modo a manter a renda na periferia nas crises, estas elevariam as importações sem aumentar as exportações, logo esgotando as reservas desses países, em uma situação insustentável.

Destarte, faz-se premente a necessidade de reduzir o coeficiente de importações desses países, e um modo de fazê-lo no longo prazo é começar a produzir internamente os bens importados.É importante ressaltar que Prebisch (1949, p. 48-49) não descarta a produção primária como incompatível com o projeto de industrialização latinoamericano, uma vez que as exportações de primários são uma fonte importante dos capitais e divisas necessários à importação dos bens de capital de que a indústria necessita. Porém, ele ressalva que as exportações são uma variável cujo controle escapa 
ao controle da periferia por depender essencialmente de fatores exógenos, como as condições da demanda mundial e do comércio internacional, sendo portanto um elemento de vulnerabilidade externa.

Reforça-se assim o diagnóstico em prol da industrialização como meio para reduzir a dependência externa da América Latina. No entanto, tendo em vista a baixa poupança e acumulação de capital latino-americana, o autor concede a necessidade do recurso ao capital estrangeiro para impulsionar o processo de industrialização, acreditando que: "se sua aplicação é eficaz, o aumento de produtividade, com o tempo, permitirá desenvolver a própria poupança e substituir com esta o capital estrangeiro" (PREBISCH, 1949, p. 72).Para isso, o autor sublinha a necessidade de não desperdiçar o uso desse capital externo ou do aumento de produtividade auferido para atender ao consumo de importados supérfluos pelas elites dominantes da periferia, ressaltando a necessidade de impor controles de importações que restrinjam as compras de supérfluos e permitam a priorização da entrada dos bens de capitais necessários à industrialização.

Entretanto, conforme visto, os Estados Unidos tenderam após a Segunda Guerra a substituir a sua assistência financeira oficial por investimentos diretos de suas empresas transnacionais, dificultando a obtenção de divisas por meio de empréstimos intergovernamentais. Além disso, as empresas transnacionais tinham importantes vantagens comparativas com relação ao setor industrial latino-americano, que estava em formação e era composto de mercados fracionados que reproduziam as mesmas indústrias em cada país da América Latina, implicando no não aproveitamento das economias de escala do continente e baixa competitividade. (PREBISCH, 1949, p. 53)

A transnacionalização das corporações norte-americanas significou no geral que os mercados nacionais foram aos poucos sendo interligados em um único mercado mundial sobre controle das matrizes nos Estados Unidos, que foram fragilizando o sistema interestatal de poder mundial. Nesse sentido, Arrighi (1994) aponta que, diferentemente da economia "extrovertida" do Reino Unido, que formou um mercado mundial interligado por laços de complementaridade econômica entre os países, os Estados Unidos são uma economia "autocentrada", tendo encabeçado um processo de "internalização" do mercado mundial por meio de suas enormes corporações transnacionais, controladoras das atividades internacionais a partir de suas matrizes nos Estados Unidos.(ARRIGHI, 1994,p. 305)

Destarte, como resultado dos processos de industrialização realizados na América Latina e da penetração das empresas transnacionais nesses países, foram 
emergindo novos centros de produção manufatureira fora do tradicional núcleo industrializado, indicando uma superação da divisão internacional do trabalho vigente.A velha separação entre mundo "industrializado" e "não industrializado" foi suplantada à medida que algumas nações em desenvolvimento lograram erguer seus próprios parques produtivos, ainda que no geral tenham contado com importante participação do capital estrangeiro, ingressando no time dos países "industrializados", mas não no dos desenvolvidos.

Cabe ressaltar que, conforme avaliação de Arrighi (1998), a corrida pela industrialização ocorrida neste período na maior parte dos países em desenvolvimento foi uma "ilusão do desenvolvimento", tendo em vista que a industrialização é apenas um meio para o desenvolvimento, não sendo garantia de sua ocorrência. Nas palavras do autor: "a industrialização apareceu não como o desenvolvimento da semiperiferia, mas como a 'periferalização' das atividades industriais” (ARRIGHI, 1998, p. 24).

Nesse sentido, Love (1996, p. 244) aponta que na passagem dos anos 1950 para os anos 1960 foi-se constatando que a dependência externa aumentara com o avanço do processo de industrialização em vez de diminuir, evidenciando que, apesar de ter-se reduzido a propensão a importar bens de consumo, aumentara a dependência da importação de insumos industriais e bens de capital. A recém-instalada indústria de bens de consumo tinha maior propensão a importar do que o setor agrícola tradicional, de modo que a sua consolidação elevou a propensão a importar da economia como um todo, em vez de reduzi-la. Isso acabou reforçando a dependência das exportações de primários e de capitais estrangeiros para suprir as necessidades de importação de insumos industriais e equipamentos, um diagnóstico que acabou levando à revisão do paradigma industrialista como instrumento do desenvolvimento por alguns de seus principais teóricos, como por exemplo Celso Furtado em seus escritos dos anos 1970.

Em termos gerais, Arrighi (1994, p. 307-308) avalia esse intervalo como um período excepcional de crescimento econômico, constituindo uma fase de "expansão material" e crescimento do comércio e da produção, na lógica do capitalismo de corporações norte-americano. Essa fase de "expansão material"do regime centrado nos Estados Unidos deu-se em uma velocidade, escala e alcance maiores do que em qualquer ciclo anterior. Porém, como em todas anteriores, resultou na intensificação da competição interempresarial e interestatal pelo capital circulante -com a recuperação da Europa e do Japão e a criação de suas respectivas empresas transnacionais -, até que as atividades produtivas e comerciais deixaram de ser suficientemente lucrativas, levando 
à consequente retirada do capital para as esferas financeiras.Nas palavras de Dicken (1998,p. 24): “As pessoas começaram a achar que os dias de 'montanha-russa' haviam terminado. [...] Mas então, nos anos 70[...] o longo 'boom' estourou e a montanha-russa retornou com uma vingança”.

\subsection{A EXPANSÃO FINANCEIRA DOS ANOS 1970}

Analogamente a todos os ciclos sistêmicos de acumulação anteriores, Arrighi (1994, p. 309-310) aponta que foi de elementos internos ao próprio sucesso do regime de acumulação norte-americano que nasceram as suas falhas, determinando o fim da sua fase de expansão material. De forma similar, também para Dicken (1998, p. 24-25) a descontinuidade dessas duas décadas de prosperidade e estabilidade econômica foi um resultado das suas "tendências globalizantes", referindo-se à transnacionalização do processo produtivo, a industrialização das zonas periféricas e a expansão do comércio mundial - fatores que em seu conjunto inflacionaram os preços de commodities e intensificaram a competição internacional, reduzindo os lucros nas atividades produtivas, aumentando os fluxos de capitais financeiros internacionais e dificultando a manutenção das taxas de câmbio fixas em conformidade com o sistema de Bretton Woods.

Durante a fase de prosperidade, Arrighi (1994, p. 317) aponta que a relação complementar entre as transnacionais e o governo norte-americano, o grande fator propulsor da fase de expansão material, foi aos poucos se deteriorando em conflitos e contradições crescentes. Com o fortalecimento e consolidação de seus impérios internacionais, as corporações norte-americanas começaram a fugir do controle de Washington, favorecidas pela natureza "transnacional" de suas atividades, espalhadas pelas mais diversas jurisdições e sob o controle total de nenhuma: "longe de serem instrumentos à disposição do poder estatal, estas empresas cedo se transformaram no limite mais fundamental desse poder" (ARRIGHI, 1994, p. 317).

Além disso, nos anos 1950 e 1960, as corporações norte-americanas tinham conseguindo se expandir com sucesso na Europa, que estava em reconstrução. Aos poucos, foram depositando seus lucros em bancos e fundos europeus, alimentando fundos de dólares fora dos Estados Unidos, que logo passaram a abrigar também os 
dólares provenientes dos superávits comerciais de alguns países europeus. Formaram-se assim os mercados de eurodólares, cuja expansão acabou gerando uma estrutura de organizações financeiras fora do controle do Sistema FED e da sua atividade regulatória, de tal forma que este foi aos poucos perdendo sua capacidade de controlar o dólar e a liquidez mundial. (ARRIGHI, 1994, p. 308-314)

De sua parte, o cenário para as empresas transnacionais também foi se deteriorando, com a expansão das suas atividades encontrando limites no incremento da competição entre elas próprias e na recuperação das empresas europeias e japonesas, que se adaptaram com sucesso ao modelo organizacional norte-americano. Destarte, Arrighi (1994, p. 312-316) aponta que a fase de expansão material norte-americana rapidamente desembocou em fortes pressões competitivas, tanto comerciais quanto de investimentos diretos estrangeiros, caracterizando os anos 1970 com uma intensa competição entre transnacionais norte-americanas, europeias e japonesas, acompanhada pela alta dos preços de insumos e por uma "explosão de salários”, em uma inflação de custos mundial que contraiu significativamente os lucros empresariais.

Nesse sentido, Frieden (2008, p. 369-371) aponta que, nos anos 1970,o sentimento de desconfiança e as tensões culturais, sociais e políticas com relação aos investimentos diretos estrangeiros de transnacionais se intensificaram. Os países desenvolvidos (como Canadá, França e Japão) passaram a monitorar, controlar e limitar os investimentos diretos estrangeiros, enquanto os países em desenvolvimento programaram intervenções que foram desde excluir as transnacionais de certos setores até a imposição de condições para a entrada, como não competir com as firmas locais, reinvestir lucros ou trazer tecnologias novas.

Em paralelo,o autor ressalta que o sucesso europeu e japonês no comércio exterior significou um grande crescimento das importações principalmente dos Estados Unidos, o exportador original, gerando ressentimento e pressões protecionistas das suas pioneiras indústrias exportadoras. Essa reação protecionista foi logo se espalhando entre os membros do GATT, que como já haviam se comprometido em não aumentar as tarifas de manufaturados, começaram a inventar novas barreiras "não-tarifárias", como ameaças de retaliação antidumping e pressões para adoção por alguns países exportadores de restrições voluntárias às suas exportações. (FRIEDEN, 2008, p. 369371)

Como resultado, o superávit comercial dos Estados Unidos com o resto do mundo foi se transformando em déficit, e os países europeus e o Japão começaram a 
acumular crescentes reservas internacionais, das quais uma pequena parte era ouro, mas o grosso eram dólares e títulos do Tesouro norte-americano. Como nota Eichengreen (2012, p. 157): “em 1948, os Estados Unidos detinham mais de dois terços das reservas monetárias mundiais; no prazo de uma década, sua participação havia caído para 50\%".

$\mathrm{Na}$ realidade, sendo o dólar a moeda de reserva mundial, os Estados Unidos podiam gastar e emitir quantos dólares os demais países estivessem dispostos a adicionar às suas reservas internacionais, acumulando passivos oficiais no exterior sobre cada vez menos ouro. Para Kindleberger (1990,p. 225-226), os Estados Unidos se tornaram assim "o banqueiro do mundo, gastando no estrangeiro, investindo, emprestando e concedendo ajuda em quantidades que ultrapassavam os dólares ganhos com as receitas de exportações de bens e serviços".

Em sua visão, essa foi a raiz primária do enfraquecimento da hegemonia dos Estados Unidos. Resgatando o alerta do economista Robert Triffin, que já no fim dos anos 1950 apontava a insuficiência da produção mundial de ouro para sustentar as necessidades monetárias internacionais, Kindleberger (1990, p. 227) enfatiza que a liquidez mundial acabou sendo fornecida pelo déficit externo norte-americano, mensurável pelo aumento das reservas estrangeiras, em uma situação insustentável.Segundo o conhecido "dilema de Triffin" (1947), a criação de dólares em excesso às reservas de ouro norte-americanas acabaria levando a questionamentos quanto à credibilidade do dólar, favorecendo a sua desvalorização, o que de fato começou a ocorrer já na década de 1960.

Nesse sentido, os questionamentos começaram a ser levantados mesmo por antigos aliados dos Estados Unidos, como demonstrado pela "questão de Gaulle" dos anos 1960, quando a França reiterou fortes críticas ao "privilégio exorbitante" dos Estados Unidos de emitir dólares sem limites e em um crescente superior às suas reservas de ouro. Conforme Eichengreen (2012,p. 168-182), a Europa ocidental e o Japão apoiaram o dólar como parceiros dos Estados Unidos no contexto da Guerra Fria,em troca deste arcar com uma parcela desproporcional dos gastos com defesa. Porém, essa cooperação só se sustentou enquanto os custos do apoio eram aceitáveis, pois em algum momento, interesses nacionais acabariam se sobrepondo: "na medida em que o apoio ao dólar passou a colocar em risco a estabilidade dos preços e outros objetivos econômicos domésticos, a Alemanha e outros países industrializados mostraram-se cada vez mais reticentes" (EICHENGREEN, 2012, p. 169). 
Na realidade,Arrighi (1994, p.310) aponta que a crise do poder norte-americano no âmbito monetário nos anos 1970 foi simultânea às crises em mais duas esferas, a militar e a ideológica, todas fazendo parte de um processo maior de declínio geral da hegemonia norte-americana.De forma alternativa, Kindleberger (1990, p. 229-230) aponta como elementos desse movimento o fortalecimento da Europa, liderada pela França no seu pleito por maior poder de decisão internacional, e dos países em desenvolvimento, que haviam se organizado em 1955 como Nações não Alinhadas em Bandung e como o G77 em 1964.

A insustentabilidade dessa situação levou os Estados Unidos a abandonar o padrão ouro-dólar no início dos anos 1970 e substituírem-no pelo “puro padrão dólar", com apenas o dólar como moeda de reserva mundial. Na avaliação de Arrighi (1994, p. 319), tal movimento reafirmou a centralidade de Washington, pois o puro padrão dólar significou "uma liberdade de ação sem precedentes na produção do dinheiro mundial" para o governo norte-americano. Pela simples emissão de moeda, os Estados Unidos puderam aumentar sua competitividade externa depreciando o dólar, sem implicar em um aumento da inflação doméstica graças ao caráter autocentrado de sua economia (produtora de petróleo e relativamente independente do comércio exterior), além de dar fôlego aos investimentos diretos de suas transnacionais.

Entretanto, esse privilégio de seignorage mundial teve sérias implicações. As taxas flutuantes e o puro padrão dólar permitiram uma política monetária frouxa que reforçou o crescimento dos mercados monetários offshore, como os mercados de eurodólares, fora da supervisão e controle dos governos e bancos centrais.Isto significou o aumento da volatilidade financeira e cambial, trazendo ainda mais riscos e incertezas ao comércio e produção mundiais, e gerando crescentes pressões sobre o controle dos governos nacionais sobre a entrada/ saída de recursos. Conforme Arrighi (1994), nesse período, as transações financeiras internacionais ultrapassaram em muito o valor das transações comerciais:

a substituição das taxas de câmbio fixas por taxas flexíveis associou-se, não a um refreamento, mas a uma aceleração da tendência dos governos das nações capitalistas mais poderosas a perderem o controle sobre a produção e regulação do dinheiro mundial [...] a tentativa do governo dos Estados Unidos de usar o puro padrão dólar emergente em nada contribuiu para restabelecer a primazia de Washington nas altas finanças (p. 323-324). 
No caso dos países em desenvolvimento,Eichengreen (2012, p.236-237) avalia que as dificuldades e custos de controlar os fluxos de capitais cresceram explosivamente, de modo que muitos acabaram permitindo a flutuação de suas moedas.Logo após a Segunda Guerra, a flutuação cambial não era atraente para os países com economia pequena e mercados financeiros em formação, pois a volatilidade cambial poderia trazer muita instabilidade econômica. Ademais, a maioria desses países estava implementando políticas de substituição de importações, visando justamente a proteger suas economias de choques exógenos, adotando barreiras tarifárias e controles cambiais para orientar o seu desenvolvimento econômico. No entanto, nos anos 1970 os fluxos de capitais tornaram-se ainda mais difíceis de controlar, e as economias altamente extrovertidas e dependentes de capitais externos como as do Terceiro Mundo se tornaram alvos fáceis aos ataques de especuladores cambiais.

Esses elementos que caracterizaram os anos 1970 - inflação mundial, volatilidade cambial e financeira, fluxos especulativos, explosão dos mercados monetários offshore - refletiram, para Arrighi (1994, p. 325), a mesma dinâmica que esteve por trás das crises sinalizadoras de todos os ciclos de acumulação anteriores: a fase de expansão material gerou pressões competitivas que achataram os lucros, desviando os investimentos no comércio e na produção para investimentos financeiros.

Na visão do autor, a política monetária e cambial norte-americana dos anos 1970 buscou manter uma fase de expansão material que já havia se esgotado, tendo na realidade alimentado a expansão das atividades financeiras, em vez de ajudar a sustentar a atividades econômicas "reais": “apenas uma fração da liquidez criada pelas autoridades monetárias norte-americanas se transformava em novos meios de comércio e produção. A maior parte dela transformava-se em petrodólares e eurodólares" (ARRIGHI, 1994, p. 325).

No caso do Brasil, essa abundante liquidez internacional em busca de oportunidades de investimentos veio a atender as necessidades de capitais decorrentes dos programas de "desenvolvimento" empreendidos pelos governos militares a partir de meados dos anos 1960, proporcionando um expressivo aumento do endividamento externo do Estado brasileiro, com todas as graves consequências econômicas vividas pelo país nos anos 1980. Nesse sentido, se por um lado os amplos recursos disponibilizados pela expansão financeira do regime de acumulação norte-americano tiveram um importante papel para os ciclos de investimento realizados durante os anos 1970, por outro lado também contribuíram de modo fundamental para a configuração de 
uma nova forma de vulnerabilidade externa da economia brasileira que teria sérias implicações na década posterior.

E de fato, com a piora desse cenário impulsionada pela criação da Unidade Monetária Europeia (UME) em alternativa ao dólar e pelo advento do Segundo Choque do Petróleo em 1979, Washington acabou se convencendo que "o colapso do dólar era uma possibilidade muito real" (ARRIGHI, 1994, p. 335), levando o governo dos Estados Unidos a buscar uma aliança com Wall Street e se unir às altas finanças privadas para resgatar os fundamentos da moeda forte e recentralizar o controle da liquidez mundial. Foi quando Carter optou por fortalecer a moeda e apertar a política monetária norte-americana, em uma nova "aliança" entre Estado e capital que, conforme Arrighi (1994, p. 335-336), propiciou a belle époque de prosperidade da era Reagan nos anos 1980, assentada em uma nova rodada de gastos militares, explosão da dívida externa norte-americana e desregulamentação das atividades financeiras.

Para o Terceiro Mundo, porém, o aperto da política monetária norte-americana e a recentralização do controle da liquidez internacional nos Estados Unidos significou as crises das dívidas dos anos 1980 devido à alta das taxas de juros internacionais,além de uma drástica redução da demanda mundial por primários.

Essa união de Washington com as altas finanças se traduziram, conforme Dicken (1998) e Gilpin (2000), na falta de regulação e controle dos mercados financeiros, intensificando a instabilidade econômica mundial.Esses desenvolvimentos, na avaliação de Arrighi (1994), muito se assemelham aos estágios finais dos ciclos de acumulação anteriores, em que a excessiva despreocupação com a liberdade dos mercados financeiros e a tolerância com as dívidas prenunciaram o declínio de cada ciclo. Em seu diagnóstico, a aliança de Washington com Wall Street apenas deslocou a crise de um conjunto de relações para outro: "era só uma questão de tempo para que ela reemergisse sobre formas mais problemáticas" (ARRIGHI, 1994, p. 336).

Portanto, apesar de os Estados Unidos permanecerem como centro hegemônico da economia-mundo capitalista, seus problemas cresceram na medida em que Washington foi encontrando dificuldades para continuar controlando essa estrutura político-econômica internacional. Contribuíram para isso a intensificação da concorrência que levou ao achatamento de lucros e às pressões de abastecimento, o enfraquecimento do contexto da Guerra Fria e o surgimento de uma nova pluralidade de atores e organizações com autonomia e capacidade crescentes de atuação internacional - as próprias empresas transnacionais, os mercados de eurodólares e outros mercados 
financeiros, as economias europeias e japonesa em ascensão, o Terceiro Mundo e a novidade dos países subdesenvolvidos e industrializados.

Um mundo muito mais complexo, portanto, em que as oportunidades de lucro e crescimento tornaram-se mais difíceis e disputadas, e onde a volatilidade financeira e instabilidade econômica aumentaram consideravelmente. Se de um lado abriram-se espaços para o surgimento de potências alternativas ao status quo, inclusive com aberturas para a ascensão das chamadas "potências médias" entre os países em desenvolvimento, por outro lado o retorno do capital às vias financeiras determinaram uma crescente instabilidade econômica que desde os anos 1970 tem afligido diversos países, desenvolvidos e em desenvolvimento, como ficou atestado pelos choques do petróleo nos anos 1970, as crises das dívidas dos anos 1980 e as crises dos mercados emergentes dos anos 1990.

\subsection{SÍNTESE: O "LONGO SÉCULO XX" E O BRASIL}

A lógica de acumulação e dinâmica evolutiva do "longo século XX" teve implicações fundamentais para a transformação estrutural da economia brasileira e o padrão de sua inserção no sistema da economia-mundo capitalista. Tendo em vista as condições domésticas do ambiente político e econômico brasileiro, as três fases do ciclo de acumulação norte-americano identificadas por Arrighi (1994) ajudaram a impulsionar processos de transformação e mudança que permitiram ao país alcançar um maior grau de complexidade econômica e modificar o seu papel na divisão internacional do trabalho, passando de periferia exportadora de primários a semiperiferia industrializada, mesmo que ainda subdesenvolvida.

Em um primeiro momento, a gradual substituição do centro britânico pelo norteamericano determinou um cenário de estrangulamento externo decorrente das duas depressões e duas guerras de escala mundial, que atingiram seriamente a periferia da economia-mundo capitalista, evidenciando a fragilidade de suas estruturas produtivas especializadas nas exportações de primários e dependentes das importações de manufaturados. Foi quando muitos governos latino-americanos assumiram o projeto de industrialização como meio de reduzir esta fragilidade, e quando as ideias que mais tarde viriam a dar corpo à Cepal, ao estruturalismo e à dependência começaram a ser 
desenvolvidas a partir de interpretações do contexto vivido pela periferia latinoamericana.

Conforme visto, este foi o período da chamada "industrialização restringida", na denominação de Tavares (1975). A indústria avançou significativamente no Brasil nesse período, aumentando a complexidade de nossa economia, que passou a contar com um setor urbano-industrial significativo e aumentou sua capacidade de sustentar uma acumulação de capital nacional, apesar de permanecer essencialmente subdesenvolvida e dependente.

Passado esse período de turbulência externa, os Estados Unidos haviam se tornado o principal país credor do mundo, o dólar tornara-se a moeda de reserva internacional, e suas empresas lideravam o crescimento da produtividade mundial. $\mathrm{O}$ Brasil já havia consolidado um setor industrial de bens de consumo leve, e o thinktank consubstanciado na Cepal começou a propor maneiras alternativas de formular as relações "centro-periferia" e de pensar a realidade dos países periféricos e suas perspectivas de desenvolvimento, fornecendo os argumentos teóricos para subsidiar a continuação dos processos de industrialização na região.

No entanto, os anos de ouro da hegemonia dos Estados Unidos vivenciaram uma forte expansão de suas corporações transnacionais, para a qual foi arquitetado todo um sistema institucional voltado à liberalização do comércio e dos investimentos diretos estrangeiros. Nessa nova lógica de acumulação, os Estados Unidos tenderam a incentivar a substituição da sua assistência financeira oficial por investimentos diretos estrangeiros de suas empresas transnacionais, que privilegiavam a acumulação de capital por suas matrizes em território norte-americano. Em paralelo, a instalação da indústria de base no Brasil exigia o recurso a capitais e tecnologias estrangeiros, de tal modo que, nas décadas de 1950 e 1960 iniciou-se um novo ciclo de industrialização caracterizado pela chamada "tríplice aliança" (EVANS, 1980) entre Estado, capital estrangeiro privado e capital nacional.

Na caracterização de Tavares (1975), este novo ciclo de industrialização foi um período de "industrialização dependente", na medida em que foi necessário o apoio do capital privado estrangeiro para a sua realização. Na realidade, não apenas a condição de dependência externa se manteve, mas em alguns sentidos ela foi até mesmo intensificada com a decorrente elevação da propensão a importar insumos industriais e bens de capital.Por outro lado, neste período houve um importante avanço da indústria de bens de consumo duráveis e de produção no Brasil,em um passo crucial para a 
transição da economia brasileira para a semiperiferia industrializada da economiamundo capitalista.

Em termos gerais, esses eventos fizeram parte de um movimento mais amplo em que a velha divisão internacional do trabalho foi sendo superada com a industrialização das zonas periféricas e a transnacionalização das atividades econômicas. No entanto, é importante enfatizar a ressalva de Furtado (1974) e Arrighi (1998), para quem essa transformação foi um "mito" ou uma "ilusão do desenvolvimento", pois muitos elementos de subdesenvolvimento e dependência dessas regiões não foram eliminados nem reduzidos, tendo apenas alterado sua configuração e formas de expressão.

Por fim, quando o regime de acumulação norte-americano começou a enfraquecer ingressando em um período de expansão financeira internacional, de perda de controle dos governos sobre os fluxos econômicos e financeiros e de intensificação da inflação de custos mundial, a economia brasileira viu-se ameaçada pelos problemas enfrentados pela economia internacional a partir dos anos 1970, principalmente em decorrência de seus vínculos de dependência de insumos industriais e bens de capital estrangeiros. A decisão pelo aproveitamento da abundante liquidez disponível permitiu a sustentação do crescimento econômico e dos projetos de "desenvolvimento" nacional, porém levou a um excessivo endividamento e aumentou a vulnerabilidade externa do país. Já dotado de uma economia complexa e industrializada, o Brasil viu-se acometido por um novo tipo de fragilidade externa, a dos capitais estrangeiros, financeiros e produtivos.

Portanto, a transformação da economia-mundo capitalista sob a égide do regime de acumulação de capital norte-americano significou a alteração dos horizontes de inserção internacional da economia brasileira, proporcionando impulsos fundamentais para a sua transformação, em graus variáveis conforme a síntese de suas próprias estruturas e condições domésticas. Como resultado, o país adquiriu um novo papel e posição na estrutura da economia-mundo capitalista, caracterizando um padrão diverso de inserção internacional de sua economia. No entanto, apesar dessa nova inserção, a economia brasileira permaneceu dependente e vulnerável às oscilações e transformações do centro da economia-mundo capitalista, o que ficaria evidente durante as décadas de 1980 e 1990. 


\section{CAPÍTULO 2 \\ O PAPEL DA POLÍTICA ECONÔMICA E DA POLÍTICA EXTERNA NA INSERÇÃO INTERNACIONAL DA ECONOMIA BRASILEIRA: 1945-1980}

\subsection{INTRODUÇÃO E CONCEITOS FUNDAMENTAIS}

O período de 1945 a 1980 presenciou uma transformação qualitativa fundamental da posição da economia brasileira e do seu papel na divisão internacional do trabalho, mesmo que mantendo sua condição dependente dos centros de dinamismo do sistema e vulnerável às suas oscilações cíclicas. Tendo o capítulo anterior fornecido o contexto sistêmico necessário à análise, o presente capítulo busca realizar uma investigação sobre a ação das políticas econômica e externa para essas transformações, de modo a delinear o seu papel, as formas de interação entre ambas as políticas, e seus resultados. De certa forma, busca-se também evidenciar como o encontro entre os desafios e oportunidades gerados pela economia-mundo capitalista e as ações estratégicas empreendidas pelo Estado brasileiro nesses seus dois eixos de atuação traduziram-se em verdadeiros impulsos transformadores da estrutura produtiva e padrão de inserção internacional da economia brasileira.

Em muitos aspectos, o conceito de "autonomia na dependência" cunhado por Moura (1980) para caracterizar o primeiro governo Vargas pode ser usado para expressar este período de transformações que, apesar de partir de outras realidades, também levou à redefinição da estrutura produtiva brasileira, do seu espaço de autonomia internacional e das condições de sua dependência. Nesse sentido, trata-se de um conceito que pode expressar uma multiplicidade de situações, apontando para as diversas configurações assumidas pela economia brasileira em sua trajetória em prol do desenvolvimento, em que a busca por maior autonomia econômica foi no geral acompanhada pela reformulação das relações de dependência e fragilidade externa.

No caso do período estudado, a importância do Estado na programação de transformações para construir uma economia mais dinâmica e endogenamente determinada foi crucial para a mudança de sua estrutura produtiva e do padrão de sua inserção internacional. Ao desenvolver instrumentos e condições para fomentar mudanças estruturais da economia brasileira, o aparato estatal teve um papel estratégico 
na alteração do relacionamento historicamente subordinado do país à lógica da economia-mundo capitalista.

A ação decisiva do Estado foi enfatizada por autores como Evans (1990) e Tavares (2010), cujas análises, conforme visto no segundo capítulo da primeira parte, demonstraram como o poder estatal foi importante para a transformação da economia brasileira em uma estrutura industrializada e complexa, apesar de manter-se subdesenvolvida e dependente de elementos externos. Na visão de Evans (1990, p. 2627), a capacidade de intervenção e planejamento do Estado na economia foi essencial para o salto da sua condição de "dependência clássica" (comercial) para um novo tipo de dependência ${ }^{72}$ (financeira e tecnológica), atuando como um Estado "empresário" que patrocinou a acumulação local e a industrialização nacional.

Para isso, todo um aparato legal, técnico e institucional foi sendo erguido, especialmente a partir das gestões de Vargas e Kubistchek, visando a dotar o governo de capacidade estratégica e gerencial para programar e realizar a transformação da economia brasileira. Conforme Tavares (2010), fez parte desse movimento a criação das empresas estatais, do Banco Nacional de Desenvolvimento Econômico e a constituição de comissões e grupos de pesquisa para o estudo da realidade brasileira e de seus problemas socioeconômicos. Algumas dessas instituições atuaram por dentro dos círculos governamentais, "como facilitadoras e transmissoras de ideias" (LOVE, 1998, p. 506): a CEPAL,o ISEB, a ESG e o IPEA - agindo ainda como formuladoras de propostas voltadas para a função inerentemente estratégica do Estado na construção de caminhos para uma melhor inserção internacional da economia brasileira.

Este papel do Estado como agente condutor da acumulação de capital local e planejador da transformação estrutural da economia envolveu uma integração entre diversas políticas públicas implementadas em âmbitos diferentes do poder estatal, as quais foram direcionadas, em maior ou menor grau, à consecução de um objetivo ou meta comum. Visando abordar interdisciplinarmente as políticas que foram voltadas à modificação da inserção internacional da economia brasileira de modo a observar as suas formas de interação, propomos o conceito de política de inserção internacional da economia brasileira, ou simplesmente PIIEB, entendida como toda ação ou projeto

\footnotetext{
${ }^{72}$ Segundo o autor, o primeiro tipo de dependência baseava-se nas relações comerciais, em que a periferia dependia da aceitação pelo centro de seus produtos para poder importar suas necessidades de consumo; enquanto o segundo tipo de dependência baseou-se no aparato produtivo, em que a expansão e melhora da capacidade produtiva da periferia dependeu "do capital de outro país". Em ambos os tipos a taxa e o objetivo da acumulação de capital foram condicionados externamente, com o setor externo mantendo sua influência central. (EVANS, 1990, p. 26)
} 
desenvolvido e implementado por agentes governamentais brasileiros com vistas a produzir algum efeito na posição e no papel da economia nacional na estrutura maior da economia-mundo capitalista.

Cabe ponderar que, apesar de sua indiscutível relevância e mérito para a pesquisa, não se insere nos propósitos desta dissertação abordar os processos decisórios que condicionaram a constituição desta PIIEB, nem a multiplicidade de agentes envolvidos em sua definição ${ }^{73}$, mas apenas as suas ações e resultados. Em seu estudo sobre a política externa brasileira, Moura (1980, p. 42-43) entende ser esta o resultado "do sistema de poder em que se situa [o Brasil], bem como das conjunturas políticas, interna e externa (a saber, o processo imediato de decisões...)". Ou seja, segundo o autor, existem dois níveis de análise envolvidos no estudo da política externa de um país dependente: o sistema de poder no qual o país se insere no plano internacional e sua posição nele (determinações estruturais) e as conjunturas políticas internas e as externas ao país (determinações conjunturais) ${ }^{74}$.

Em muitos aspectos, levando em conta que a PIIEB também envolve elementos domésticos e internacionais, estruturais e conjunturais, esta interpretação pode ser tomada como adequada para explicar a sua formulação e consecução.Os elementos estruturais foram tratados anteriormente ao abordar a dinâmica de funcionamento da economia-mundo capitalista e a posição da economia brasileira nesse sistema. No caso das conjunturas políticas internas e externas, optou-se por trabalhar diretamente com as manifestações resultantes dos processos decisórios que modularam essas conjunturas.

Retomando o conceito proposto de política de inserção internacional da economia brasileira (PIIEB), foi também fundamental para a sua construção as abordagens alternativas de Lima (1990) e Malan et al. (1977), que tratam da "economia política da política exterior brasileira" na proposta da primeira, e da "política econômica externa brasileira" na visão dos últimos. Apesar de partirem de enfoques

\footnotetext{
${ }^{73}$ Alguns autores, como Milani e Pinheiro (2012,p. 17) criticam os estudos que se limitam a abordar o papel do Estado para explicar a política externa de um país: apesar de facilitarem a análise, a tornam irreal e pouco útil. Os autores enfatizam a necessidade de rever o papel dos agentes e instituições no processo de decisão e formulação de políticas, que não se resume à atuação do Estado, apesar da centralidade deste. No entanto, a opção por focar apenas nos meios de atuação da PIIEB e seus resultado, sem abordar a natureza dos processos decisórios que a permearam, é justificado por este não ser o escopo desta dissertação.

${ }^{74}$ Apesar de o primeiro limitar o campo de ação dos agentes de política externa, Moura (1980) enfatiza que os processos decisórios não são inteiramente cativos das estruturas sistêmicas, mas guardam uma certa autonomia que lhes confere um potencial de transformação sistêmica. No entanto, essa autonomia também não é absoluta na medida em que os processos decisórios tendem a reproduzir as relações de dominação-subordinação do sistema, garantindo assim uma "estabilidade provisória" da estrutura inteira. (MOURA, 1980, p. 40-43)
} 
diferentes, ambos visaram entender a ação política relacionada à economia brasileira e sua inserção internacional, constituindo-se portanto em duas interpretações alternativas que forneceram subsídios fundamentais para compor o conceito aqui pretendido.

Partindo de perspectivas teóricas oriundas dos estudos das relações internacionais, Lima (1990, p. 7) analisou as principais abordagens teóricas sobre a política externa de países "semi-industrializados, recentemente industrializados ou semiperiféricos" (a saber, o "subimperialismo de aliados especiais", o "neorrealismo de potência emergente", e as "vantagens comparativas comerciais de caronas predatórios" ${ }^{, 75}$ ). Segundo a autora, cada abordagem tendeu a enfatizar, de maneira parcial, apenas uma postura para caracterizar a política externa desses países, quando na realidade estes tenderam a alternar ou combinar diferentes posturas ao longo do tempo.

Em sua visão, os países semiperiféricos são caracterizados por desequilíbrios entre seus recursos de poder e seus interesses, que os fazem perseguir diferentes estratégias de negociação a depender das condições do momento. A autora aponta que os países periféricos que conseguiram realizar um processo substancial de industrialização, como o Brasil, foram adquirindo aos poucos maior autonomia, mas não deixaram de serem dependentes. Desse modo, suas estruturas produtivas crescentemente complexas e industrializadas foram os diferenciando do Terceiro Mundo ao conferir-lhes interesses mais diversificados, sem no entanto adquirir capacidade para influenciar as lógicas político-econômicas mundiais:

Em função dos interesses emergentes desses países em diversas arenas internacionais e da configuração desequilibrada de seus recursos de poder, tendem a exibir padrões de comportamento e estratégias distintas e não uniformes, que resultam da estrutura particular de incentivos em áreas temáticas determinadas, dos recursos de poder específicos nessas áreas e de constrangimentos de natureza doméstica. (LIMA, 1990, p. 27)

De certo modo, esta perspectiva coaduna com a proposta de Moura (1980) para a análise da política externa do Brasil enquanto país que se consolidou na semiperiferia da

\footnotetext{
${ }^{75} \mathrm{O}$ subimperialismo de aliados especiais refere-se a países que se comportam em sua região como aliados da potência hegemônica em troca de benefícios, tendo um papel imperialista na região e de simbiose com a potência. Já o neorrealismo de potência emergente identifica o ganho de autonomia por alguns países para dissociar-se do centro hegemônico e buscar iniciativas unilaterais e bilaterais em prol de seus interesses. Por fim, as vantagens comparativas comerciais de caronas predatórios descreve $o$ comportamento de países que se aproveitaram dos conflitos comerciais entre o primeiro e o terceiro mundo para auferir benefícios econômicos. (LIMA, 1990, p. 7-10).
} 
economia-mundo capitalista ${ }^{76}$ no período estudado, na medida em que os recursos de poder e interesses dos países semiperiféricos devem ser medidos em relação às estruturas sistêmicas, além de serem conformados pelas conjunturas domésticas e externas. Assim, tendo em vista as transformações de ordem sistêmica e conjuntural da economia internacional e da própria estrutura econômica brasileira, a análise da "economia política da política externa brasileira” de Lima (1990, p. 18) se propõe a analisar a possibilidade de diversas estratégias e posturas do país, que muitas vezes pode gerar uma aparente incoerência que não necessariamente reflete uma irracionalidade dos processos decisórios.

Já Malan et al. (1977) partem de outras referências analíticas, no geral associadas ao estudo da economia política, para repensar o conjunto das análises sobre a transformação da estrutura produtiva brasileira iniciada nos anos 1930. Identificando haver uma tendência geral a negligenciar o peso do fator internacional e restringir as causas explicativas a elementos domésticos sem considerar a sua dimensão histórica, os autores buscam resgatar o papel do sistema internacional e a perspectiva temporal do processo de transformação econômico brasileiro, para relacioná-los à condução do que chamam de "politica econômica externa brasileira". Desse modo, os autores se propõem a oferecer uma nova interpretação que enfatiza não apenas o peso do sistema internacional como também a importância da consciência histórica para o estudo das transformações da economia brasileira. (MALAN et al., 1977, p. 9-13)

Novamente, esta proposta não se distancia muito da de Moura (1980) ao apontar a insuficiência das explicações restritas a elementos domésticos e resgatar a importância da situação internacional e da abordagem histórica para o estudo do papel da "política econômica externa brasileira".

Portanto, tendo em vista essas formulações, consideramos que o conceito aqui proposto de política de inserção internacional da economia brasileira (PIIEB) envolve em sua constituição uma dimensão sistêmica (estrutural ou histórica) e outra dimensão conjuntural, aqui entendida como as manifestações específicas formadas a partir das coalizões de poder e do papel do Estado. Ou seja, a dimensão sistêmica compõe uma espécie de pano de fundo indicador das coordenadas com as quais a dimensão

\footnotetext{
${ }^{76}$ Cabe ressaltar que os autores abordados neste capítulo não trabalham com o arcabouço conceitual da economia-mundo capitalista. $\mathrm{O}$ exercício aqui realizado de mesclar campos conceituais aventados como complementares, mas que não se relacionam em sua concepção original, é expressão da tentativa de identificar nessas diferentes formulações teóricas instrumentos capazes de abarcar as realidades cuja análise são objeto desta dissertação, e que podem conjuntamente ter um grande potencial explicativo.
} 
conjuntural trabalha em seu desenrolar imediato, atuando por dentro da primeira e permitindo a interação entre a economia-mundo capitalista e a economia brasileira em seus diversos momentos históricos.

As análises desses autores apontam também para a existência de uma importante inter-relação entre as ações da política econômica e da política externa que foram direcionadas com o objetivo de alterar o padrão de inserção internacional da economia brasileira e que, em nossa visão, compõem a PIIEB. Assim, esses dois grandes eixos ou canais de atuação da PIIEB, a política econômica e a política externa - entendidos nesse sentido restrito de ações que visaram especificadamente intervir e atuar no padrão de inserção internacional da economia brasileira -, reuniram diversos instrumentos de ação, desde normas e regulamentos até acordos internacionais e planos de governo, conforme o âmbito institucional em que foram conduzidos e implementados.

É importante ponderar ainda que as políticas econômica e externa no geral seguiram diretrizes e objetivos definidos por meio de processos decisórios particulares, de modo que estes não foram sempre coerentes nem complementares entre si. Por vezes, houve até uma autonomia relativa entre esses dois canais que compõem a PIIEB, o que nos remete à análise de Lima (1990), segundo a qual a aparente incoerência entre os instrumentos de uma política não necessariamente reflete uma irracionalidade dos processos decisórios ou dos agentes nela envolvidos.

As demais seções são dedicadas à análise destes instrumentos de ação da PIIEB e de suas implicações para a inserção internacional da economia brasileira. A análise manteve a divisão entre os dois grandes canais de atuação da PIIEB (a política econômica e a política externa) e busca avaliar se a relação entre ambos ao longo do período estudado foi complementar, conflituosa, de subordinação, neutra e/ou de autonomia relativa. Além disso, a fim de facilitar o trabalho investigativo, optou-se por dividir as seções por momentos político-econômicos, a saber: os governos Dutra (19461950); Vargas (1951-1954); Kubistchek (1956-1961); Quadros e Goulart (1961-1964); Castelo (1964-1967); e Costa e Silva, Médici e Geisel (1967-1979).

Cada uma dessas seções foi, por sua vez, estruturada em quatro subseções. Assim, cada seção inicia com uma contextualização do período a que se refere, seguida por uma análise da política econômica de inserção internacional da economia brasileira, e por outra da política externa correspondente. Por fim, o fechamento de cada seção produz uma conclusão comparativa das duas políticas abordadas, visando avaliar as formas de interação entre elas. 


\subsubsection{GOVERNO DUTRA (1946-1950): ADEPENDÊNCIA E A ALIANÇA NORTE-AMERICANA}

\subsubsection{Contextualização}

Durante a Segunda Guerra Mundial, o apoio do Brasil (e da América Latina) era vital para a estratégia norte-americana de "cooperação continental” perante as ameaças do nazismo alemão, especialmente como região fornecedora de insumos e matériasprimas estratégicas para os esforços de Washington na guerra. Conforme Moura (1991, p. 5), tal conjuntura determinou uma mudança fundamental na postura da potência hegemônica perante o continente, que passou a prezar o diálogo com as nações latinoamericanas e recuou do tradicional intervencionismo, ou distanciamento benigno, que a caracterizara nas últimas décadas:

Inaugurou-se então a política de boa vizinhança, caracterizada pela revogação de métodos coercitivos e pela adoção de negociações diplomáticas e colaboração econômica e militar. [...] essa mudança de métodos visava a assegurar objetivos tradicionais: impedir a influência externa (europeia) na América Latina, garantir a liderança americana no hemisfério e estimular a estabilidade política nos países latino-americanos.

Esta necessidade de assegurar a cooperação continental abriu espaço para o Brasil negociar o seu apoio aos Estados Unidos e demandar benefícios em troca do seu alinhamento, em uma política de barganhas empreendida durante o governo Vargas. Conforme Moura (1991, p. 189), essa política buscou atuar com "autonomia na dependência" para angariar o auxílio norte-americano ao projeto de desenvolvimento brasileiro, quando Vargas logrou auferir consideráveis concessões e benefícios da potência norte-americana em troca do seu apoio na guerra.

No entanto, passada a Segunda Guerra, o Brasil e a América Latina deixaram de ser prioritários na política internacional norte-americana. Tendo se afirmado como única potência ocidental, os Estados Unidos ingressaram em um processo de construção de uma nova ordem internacional estruturada em torno de seus interesses, almejando a consolidação de um sistema mundial de segurança e de um ambiente econômico propício à sua lógica de acumulação de capital. Neste novo contexto, a Europa, a África 
e a Ásia figuravam como áreas política e economicamente mais importantes do que a América Latina. (CERVO E BUENO, 2008, p. 270; MOURA, 1991, p. 22-24)

Os novos interesses dos Estados Unidos para a América Latina passaram a girar em torno da adesão da região aos princípios da nova ordem internacional que estava sendo construída, materializada nos Acordos de Bretton Woods (1944), na criação da Organização das Nações Unidas (1945) e na construção da Guerra Fria. Em outras palavras, buscou-se afirmar a liderança norte-americana na região. Nesse sentido, no que diz respeito ao desenvolvimento econômico do continente, Moura (1991, p. 64) aponta que Washington tinha três linhas de interesse: o aumento das exportações de primários da região para os Estados Unidos; o aumento do comércio intracontinental (entre os países latino-americanos); e a industrialização da América Latina, desde que restrita à indústria de bens leves e preferencialmente sob o controle do capital transnacional norte-americano. Isto é, o objetivo era reduzir o comércio com outras regiões como a Europa e da Ásia, e incrementar as ligações econômicas com os Estados Unidos com base no fornecimento de primários latino-americanos e na importação de manufaturados norte-americanos ${ }^{77}$.

Desse modo, os Estados Unidos tentaram convencer os países latino-americanos a aderir aos princípios de Bretton Woods e a cooperarem com os seus objetivos para o continente, dentro da estratégia maior de construção de uma nova ordem internacional sob sua liderança. Uma importante expressão disso foi a Conferência Interamericana de 1945 (do México ou de Chapultepec), quando os Estados Unidos conseguiram acordar a garantia do tratamento igualitário para o capital estrangeiro no continente, defendendo a ideia de que o desenvolvimento da América Latina seria alcançado com o uso de investimentos privados, nacionais ou estrangeiros, em igualdade de condições. $\mathrm{Na}$ ocasião, os Estados Unidos também pressionaram a aprovação de uma moção sobre assistência e solidariedade em caso de agressões externas e internas ao continente, sob sua liderança. Ou seja, nas palavras de Moura (1991, p. 48): “a Conferência do México

\footnotetext{
${ }^{77}$ De forma sumária, Moura (1991, p. 97-98) resume a política norte-americana para a América Latina nesse período em quatro pontos: a intenção de construir seu sistema de poder a partir da América Latina (por meio de tentativas de manipular a economia, a política exterior, a organização militar e a vida cultural latino-americana); de fortalecer os vínculos econômicos com seus aliados conforme seus interesses (insistência no liberalismo e na manutenção da divisão internacional do trabalho tradicional, relutando em conceder empréstimos à industrialização e forçando os princípios de Bretton Woods); de articular política e militarmente os membros do seu sistema (intensa negociação, pressões e benefícios para garantir o alinhamento); e de disseminação de uma ideologia política de manutenção do equilíbrio do sistema (legitimação da sua hegemonia como um benefício comum a todos).
} 
instaurou o intervencionismo que tinha sido tão solenemente renegado nos anos 1930 com a "política da boa vizinhança"”.

Em paralelo, o autor aponta que, entre as elites brasileiras, havia uma ideia de que o país estaria destinado a ser uma grande potência, em uma "gama de ilusões ufanistas" decorrentes da "dificuldade de avaliar as possibilidades de atuação do Brasil no sistema internacional" (MOURA, 1991, p. IX). A gestão Dutra partilhava desse ideal, acreditando ainda que o país deveria participar da construção da nova ordem internacional norte-americana, por meio de uma relação especial com os Estados Unidos que permitiria ao Brasil destacar sua superioridade econômica e militar na América Latina. Assim, o período Dutra foi um de "alinhamento sem recompensa" aos Estados Unidos (MOURA, 1991, p. 59), marcado em grande medida pelo anticomunismo, pela repressão aos movimentos sociais, pela adesão aos princípios de Bretton Woods e pelo americanismo como paradigma.

No entanto, neste período também crescia gradualmente a percepção latinoamericana sobre a realidade de suas especificidades históricas e de suas perspectivas para o desenvolvimento, tendo em vista a estrutura e lógica de funcionamento da economia-mundo capitalista. Formulações de pensadores de diferentes gerações e regiões como Friedrich List, Raul Prebisch, Mihail Manoilescu e até mesmo Charles Kindleberger e Paul Rosenstein-Rodan, que defendiam a industrialização dos países agrários atrasados, ganhavam então alcance e influência no continente (LOVE, 1998). Além disso, novos espaços de questionamento e discussão de ideias sobre o desenvolvimento das economias "atrasadas" se abriam, como as agências da ONU, das quais se destacou a Comissão Econômica para a América Latina (CEPAL), criada em 1948.

Em especial, a CEPAL teve um papel fundamental na formulação de ideias e proposições sobre a realidade periférica latino-americana e suas perspectivas de desenvolvimento. Com a chegada de Prebisch em 1949 na liderança da CEPAL, suas ideias sobre a natureza das relações centro-periferia começaram a ganhar alcance internacional, provendo aos países latino-americanos uma fundamentação teórica para seus projetos de industrialização. Ao evidenciar a especificidade histórica latinoamericana, denunciou-se as injustiças da dinâmica desigual da estrutura "centroperiferia" e iniciou-se a difusão de ideias sobre a possibilidade do crescimento "voltado para dentro" das economias latino-americanas, amparado por um processo de industrialização sob a condução estratégica do Estado. 
Em parte como reação a esses eventos, em 1949 o presidente Truman propôs o Act of International Development (AID), pressionado pela conjuntura de intensificação da Guerra Fria e insatisfação dos países latino-americanos com a falta de apoio efetivo dos Estados Unidos para os seus processos de desenvolvimento e industrialização. A proposta visou a eliminar a ameaça comunista por meio do auxílio ao desenvolvimento capitalista dos países em desenvolvimento e criar mercados para os produtos norteamericanos por meio da redução da pobreza nesses países. Sinalizava-se assim, já no final da gestão Dutra, senão uma maior colaboração, uma maior atenção de Washington às demandas de desenvolvimento latino-americanas.

\subsubsection{Instrumentos da política econômica}

A política econômica da gestão Dutra iniciou sua atuação empreendendo medidas conservadoras de combate à inflação e contenção de gastos públicos. Em contrapartida, buscou angariar recursos externos para financiar seus projetos de desenvolvimento econômico. Desse modo, na expectativa de atrair expressivos fluxos de capitais externos, o câmbio oficial foi mantido fixo conforme o sistema de paridades estabelecido em Bretton Woods, e a liberdade de negociação cambial foi restabelecida por meio do Decreto-Lei $\mathrm{n}^{\circ} 9025$ de 1946, que revogou algumas das tradicionais restrições a pagamentos e remessas de capitais ao exterior. Buscou também apoio financeiro oficial do governo norte-americano e de suas agências, como as tentativas de obter recursos de Washington para o reequipamento dos transportes marítimos e terrestres nacionais, e do Eximbank para a construção de uma refinaria de petróleo. (Vianna, 2011, p. 105-106)

No entanto, as entradas de capitais privados e oficiais esperadas foram frustradas, ao mesmo tempo em que o contexto pós-guerra significou a retomada do crescimento econômico nacional e a restauração das importações, sobre condições de uma taxa de câmbio valorizada em termos reais em decorrência da aceleração dos preços domésticos durante a guerra. Assim, Moura (1991, p. 68) aponta que a paridade cambial logo começou a mostrar-se insustentável, pressionada pela crescente necessidade de importações que estava levando ao rápido esgotamento das reservas internacionais. Em consequência, sob a orientação do FMI, em 1947 foi estipulada a Lei 
$\mathrm{n}^{\circ} 156$, que determinou o fim do mercado livre de câmbio, a reintrodução dos controles cambiais e de medidas de contingenciamento de importações, de modo a beneficiar a importação de bens de capital e de insumos industriais, além de restringir importações de bens concorrentes aos produzidos nacionalmente.

Estas determinações foram complementadas por meio de diversas instruções da SUMOC, como a Instrução ${ }^{\circ} 25$ de 1947 que centralizou as autorizações de licenças de importação na Carteira de Exportação e Importação do Banco do Brasil e determinou a adoção de critérios de essencialidade para importações conforme o "interesse nacional". Analogamente, a Instrução ${ }^{\circ} 26$ de 1948 obrigou o repasse de câmbio ao Banco do Brasil pelos bancos autorizados a operar com câmbio; a n 28 de 1949 estabeleceu cinco categorias de importações para classificação de prioridades para fornecimento de câmbio; a n 29 de 1949 estabeleceu a necessidade de prévia autorização da SUMOC para transferências de moeda estrangeira superiores a Cr\$ 10 mil; e a $n^{\circ} 30$ de 1950 proibiu a remessa de câmbio para alguns fins, como viagens e pensões.

Para além dessas intervenções mais diretas no mercado cambial, cabe destacar ainda a atuação da SUMOC na negociação de convênios comerciais com outros países. Conforme Figueiredo Filho (2005, p. 124-129), em 1948 o Conselho da SUMOC começou a revisar e negociar convênios bilaterais de comércio visando a melhorar as posições cambiais brasileiras com seus parceiros comerciais e viabilizar importações por meio do uso de saldos em moeda inconversível e até mesmo trocas diretas. Segundo o autor, ao longo dos anos, esta atuação da SUMOC nos acordos bilaterais foi crescente, tendo chegado a examinar o restabelecimento de acordos comerciais com a Alemanha e o Japão em 1950.

Ou seja, ao longo do governo Dutra o eixo da política econômica foi se alterando conforme lhe foram sendo colocados constrangimentos externos, que obstavam seu projeto de desenvolvimento. Neste sentido, a Lei $\mathrm{n}^{\circ} 156$ de 1947 e as Instruções posteriores da SUMOC foram na direção contrária das disposições do Decreto-Lei $\mathrm{n}^{\circ} 9025$ do ano anterior. No entanto, mantiveram-se as linhas gerais de alinhamento aos Estados Unidos e de busca do seu apoio para a economia nacional.

Mesmo com os pleitos frustrados por apoio financeiro norte-americano, Cervo e Bueno (2008, p. 270-271) apontam que a gestão Dutra continuava acreditando no status de "aliado especial" dos Estados Unidos, esperando angariar sua ajuda direta ao programa de desenvolvimento nacional. Assim, em 1949 a gestão Dutra propôs uma iniciativa de intervenção planejada do Estado para o desenvolvimento econômico: o 
Plano SALTE (Saúde, Alimentação, Transporte e Energia), prevendo investimentos públicos em setores considerados essenciais para a estratégia de desenvolvimento, e que contariam com recursos provenientes da receita federal e de empréstimos externos, especialmente norte-americanos. Tendo essas expectativas frustradas, o Plano SALTE foi abandonado em 1951, mas resultou na construção das seguintes obras: o Hospital dos Servidores do Estado (RJ), planejado para ser o maior hospital da América Latina; a Rodovia Rio-Bahia e a nova Rodovia RJ-SP (Rodovia Presidente Dutra); e a Usina Hidrelétrica de Paulo Afonso, no Rio São Francisco.

O governo norte-americano insistia que tais assuntos fossem tratados no âmbito do BIRD ou pela atração de investimentos diretos privados. Assim, quando em 1948 as negociações com Washington consubstanciaram-se na formação da Missão Abbink, esta se propôs a estudar os principais problemas da economia brasileira e formular projetos de desenvolvimento, porém sem almejar a obtenção de financiamentos externos oficiais, apontando em seu lugar o uso de recursos brasileiros ou de capitais privados estrangeiros ${ }^{78}$.

De forma sumária, o resultado desta missão, conhecido como Relatório Abbink, diagnosticava que a economia brasileira tinha como problemas estruturais as dificuldades para controlar a inflação, manter as importações e formar um mercado de capitais para estimular o capital privado. Em conclusão, o Relatório considerava a estabilização de preços uma condição para o desenvolvimento, devendo ser alcançada por meio do controle orçamentário e da contenção do crédito. Uma ruptura, portanto, por retomar o enfoque no controle inflacionário e no estímulo aos investimentos estrangeiros diretos de empresas multinacionais. Uma vez estabilizada a economia, o programa de desenvolvimento deveria se fundamentar no afluxo de capitais estrangeiros, na reorientação dos capitais nacionais para setores estratégicos por meio da política fiscal, e na organização de um mercado de capitais e do sistema monetário e creditício. (MALAN et al., 1977, p. 47-59)

Conforme esses autores, o relatório tratava de duas grandes polêmicas à época. A primeira girava em torno do papel do Estado na coordenação dos investimentos, devido às lacunas deixadas pelo setor privado, e na gestão das restrições cambiais, com medidas como a produção doméstica dos bens antes importados (especialmente fontes de energia) e a restrição às importações não essenciais. $\mathrm{O}$ segundo ponto sensível era a

\footnotetext{
${ }^{78}$ Foi em 1948 que também foi criada a Escola Superior de Guerra (ESG), com o apoio do governo norteamericano.
} 
ênfase ao papel do capital privado estrangeiro, também considerado necessário tendo em vista a deficiência do capital nacional. Em particular, Tavares (2010, p. 15) aponta que existia naquele momento severas críticas de setores da sociedade brasileira ao privilégio conferido pelos Estados Unidos à Europa com a assistência oficial do Plano Marshall, enquanto à América Latina era reservado o discurso do investimento direto estrangeiro.

Com o início das hostilidades na Coréia em 1950 e a antecipação da vitória de Getúlio Vargas nas próximas eleições, em um contexto de intensificação da Guerra Fria, a insatisfação latino-americana passou a ser elemento de preocupação para o presidente Truman, levando-o a aprovar o AID e a constituir a Comissão Mista Brasil-Estados Unidos para o Desenvolvimento Econômico (CMBEU) a partir dos trabalhos da Missão Abbink. Conforme Malan et al. (1977), o objetivo principal da CMBEU era estudar meios de eliminar "os pontos de estrangulamento em alguns setores básicos, como transporte e energia" (p. 34), devendo elaborar para isso projetos "concretos e bem trabalhados, suscetíveis de imediata apreciação por instituições financeiras, tais como o Banco de Exportação e Importação e o Banco Internacional de Reconstrução e Desenvolvimento" (p. 33). Preparava-se assim, no final do governo Dutra, o terreno para a programação iniciada no segundo governo Vargas em prol de seu projeto de desenvolvimento nacional.

Portanto, tendo em vista este breve apanhado sobre a política econômica de inserção internacional da economia brasileira, podemos elencar como instrumentos que a compuseram:

- Decreto-Lei nº 9025 de 1946 (flexibilização cambial e revogação de restrições a pagamentos e remessas de capitais ao exterior);

- Lei n 156 de 1947 (fim do mercado livre de câmbio, reintrodução de controles cambiais e de medidas de contingenciamento de importações);

- Plano SALTE (investimentos em saúde, alimentação, transporte e energia);

- Atuação da SUMOC no controle de importações "prioritárias" e nas remessas para o exterior (Instruções $\mathrm{n}^{\circ} 25$ de 1947, $\mathrm{n}^{\circ} 26$ de 1948, $\mathrm{n}^{\circ} 28$ de 1949, $\mathrm{n}^{\circ} 29$ de 1949 e n 30 de 1950) e na negociação de acordos comerciais bilaterais;

- Missão Abbink (estudos em colaboração com os Estados Unidos para identificar os problemas da economia brasileira e propor projetos de desenvolvimento com o uso de recursos brasileiros ou de capitais privados estrangeiros). 


\subsubsection{Instrumentos da política externa}

No geral, a política externa e a gestão Dutra alinharam-se às orientações norteamericanas e atuaram no sentido de apoio à política dos Estados Unidos. Desse modo, a política exterior brasileira no geral seguiu o voto de Washington nos fóruns de deliberação multilateral, e apoiou seus interesses no Brasil, na América Latina e nas arenas internacionais. Segundo Cervo e Bueno (2008, p. 272), pelo menos na ONU, “a orientação do Brasil, à época do presidente Dutra e do chanceler Raul Fernandes, era de acompanhamento do voto dos EUA". Assim, o Brasil assinou o Tratado Interamericano de Assistência Recíproca (TIAR) em 1947, criando mecanismos de manutenção da paz e da segurança do hemisfério sob a liderança dos EUA; e rompeu relações diplomáticas com a União das Repúblicas Socialistas Soviéticas (URSS) no mesmo ano.

Além disso, em 1946 quando ocorriam os debates da Assembléia Constituinte que definiriam a nova Constituição brasileira, Moura (1991) aponta que os capítulos sobre a ordem econômica atraíram especial atenção dos americanos e britânicos, que tinham interesses em garantir a igualdade dos capitais estrangeiros perante os capitais nacionais. Em especial, seus interesses de concentravam no setor do petróleo e outros insumos estratégicos, conseguido o apoio da diplomacia brasileira, tendo em vista que “a administração federal brasileira aceitava sem restrições as teses econômicas de Chapultepec e o Itamaraty destacava-se nesta posição" (MOURA, 1991, p.68).

No caso do petróleo, a reação nacional contra a presença do capital estrangeiro levou o governo a recuar na disposição pró-empresas estrangeiras. Porém, aponta Moura (1991, p. 68-69), em outros casos, como o do manganês, a US Steel e a Bethleem Steel conseguiram autorização para a sua exploração por 50 anos.

Apesar da tendência geral ao alinhamento da diplomacia brasileira, Moura (1991) nota ter havido uma crescente "dissonância" de interpretações entre a delegação diplomática brasileira na ONU e a orientação geral do Itamaraty, em especial no que diz respeito à bipolaridade Leste-Oeste. Segundo o autor, quando em 1946 Osvaldo Aranha, chefe da delegação brasileira na ONU, foi eleito presidente do Conselho de Segurança deste organismo, a delegação brasileira pode adquirir uma visão mais complexa da situação internacional e adotar a partir desta uma atitude mais independente e consciente da verdadeira natureza das disputas internacionais: 
Osvaldo Aranha [...] percebeu que não havia guerra global entre Estados Unidos e União Soviética, que algum grau de colaboração era visível entre as duas grandes potências e que os EUA não estavam interessados no continente americano, mas jogavam para valer na Europa e Ásia. (MOURA, 1991, p. 62)

O autor aponta que esta posição contrastava com a do chanceler Raul Fernandes e do presidente Dutra, que se pautavam pelo conflito Leste-Oeste, pela necessidade de alinhamento incondicional aos EUA e pela luta contra o comunismo. Essa dissonância também é notada por Cervo e Bueno (2008), que citam como exemplos concretos o não reconhecimento da República Popular da China e a reprovação de seu ingresso na ONU por orientação presidencial e do Itamaraty, em que "Osvaldo Aranha seguiu o voto norte-americano, embora contrafeito e sem fazer defesa em plenário, pois, pessoalmente, era favorável ao reconhecimento da China Popular e ao seu ingresso na ONU” (p. 272-273).

Cabe destacar ainda a repercussão no Brasil das ideias que começavam a ser divulgadas pela recém-criada CEPAL (Comissão Econômica para a América Latina), por intermédio de intelectuais engajados como Celso Furtado, e que tiveram ampla aceitação principalmente na classe empresária industrial brasileira. Conforme Furtado (1985, p. 84-85), no Terceiro Período de Sessões da CEPAL em 1950, a delegação brasileira (formada por diplomatas do Itamaraty e técnicos ligados ao Ministério da Fazenda) não havia recebido instruções precisas sobre como se posicionar com relação aos trabalhos técnicos apresentados pela CEPAL, tendo assumido uma postura tímida de não comprometimento e abstenção. No entanto, o autor destaca a posição do secretário de embaixada Azeredo da Silveira, que defendeu ativamente a aprovação de uma proposta com dez projetos referentes ao desenvolvimento latino-americano elaborados a partir dos trabalhos da CEPAL, em um documento que ficou conhecido como o "Decálogo de Montevidéu".

Entre outras propostas, o documento recomendava medidas de planejamento no desenvolvimento de atividades econômicas, de atenuação dos desequilíbrios externos e de abstenção por parte dos países desenvolvidos a tomarem medidas prejudiciais às exportações latino-americanas. Além de provocar forte oposição norte-americana e britânica, o Decálogo evidenciou o importante apoio técnico que a CEPAL começara a prover aos países latino-americanos para amparar suas políticas de industrialização e desenvolvimento sob o controle do Estado. Ademais, aponta Furtado (1985, p. 103), no 
Brasil as ideias da CEPAL encontraram espaço para germinar, especialmente dentre os defensores da industrialização, para os quais "a industrialização não seria propriamente uma opção, era a única saída para prosseguir com o desenvolvimento”.

Portanto, em paralelo à tendência geral de alinhamento e apoio às determinações norte-americanas, alguns sinais de distanciamento, ainda que tímidos e pontuais, foram percebidos principalmente no âmbito da ONU e da CEPAL, refletindo o surgimento de uma interpretação diversa à visão geral do MRE sobre a estrutura de poder internacional e a real dimensão do conflito Leste-Oeste para o Brasil. Se nos primeiros anos essa dissonância não teve implicações concretas, com a manutenção do americanismo e da bipolaridade, esse cenário começou a se alterar com a criação e progressiva consolidação da CEPAL como fórum alternativo para discussão de políticas de industrialização, como ficou atestado na elaboração do Decálogo.

Em suma, destacamos como instrumentos da política exterior de inserção internacional da economia brasileira deste período:

- alinhamento aos Estados Unidos (nas votações da ONU e em questões domésticas como às referentes à participação do capital estrangeiro na economia brasileira), depois atenuado no final do período;

- Decálogo de Montevidéu de 1950 (recomendações tecnicamente apoiadas pela CEPAL em prol do desenvolvimento latino-americano, contrárias aos interesses dos países industrializados e que consubstanciaram a importância da CEPAL como foro de discussão e defesa de políticas de industrialização).

\subsubsection{Comparação e resultados}

Do lado da política econômica, os instrumentos utilizados parecem confirmar uma atuação em prol de uma inserção internacional da economia brasileira diferente desde que os interesses dos Estados Unidos não fossem contrariados, mantendo o alinhamento e a ilusória percepção de "aliado especial" de Washington em seu projeto de construção de uma nova ordem internacional. Nesse sentido se explicam a Lei $\mathrm{n}^{\circ} 156$ de 1947 e as diversas Instruções da Sumoc, que apesar de não se conformarem aos princípios de Bretton Woods, contaram com o apoio de Washington e do FMI, na medida em que não contrariavam os interesses da potência hegemônica. 
Portanto, o aparente (e restrito) apoio norte-americano ao desenvolvimento brasileiro durante o governo Dutra foi moderado pelos interesses dos Estados Unidos em garantir o fornecimento de insumos e matérias-primas para suas indústrias, a exportação de seus manufaturados para os mercados brasileiros, e impedir a influência de terceiros na região - ou seja, de construir uma economia complementar à norteamericana. Na realidade, esta postura fez parte da estratégia de Washington para a América Latina como um todo, tendo envolvido a redução da dependência latinoamericana de outras regiões como a Europa e a Ásia e a consolidação da liderança norte-americana no continente.

No entanto, a expectativa de auxílio efetivo dos Estados Unidos às aspirações brasileiras de desenvolvimento sempre se fez presente nas relações entre os dois países. Em particular, ela foi adquirindo um tom reivindicatório, e de forma crescente principalmente diante do surgimento de novas interpretações sobre a real condição da estrutura centro-periferia e das perspectivas do desenvolvimento da periferia, além da percepção da diferença de tratamento no auxilio oficial conferido à Europa com o Plano Marshall.

A Missão Abbink foi um meio de os Estados Unidos responder às pressões por financiamento oficial para o desenvolvimento brasileiro. Apesar de ter reforçado a recomendação pelo financiamento por capitais privados americanos, o relatório da missão apontava o papel estratégico do Estado na coordenação dos investimentos e no preenchimento das lacunas deixadas pela iniciativa privada, sancionando a importância da ação estatal na economia. Além disso, conforme ressaltado por Martins (1975, p.37), a missão organizou uma base de dados sobre a economia brasileira até então inexistente, propiciando condições para fomentar o debate mais qualificado sobre seus problemas. Para o autor, o principal mérito dos estudos gerados pela missão, e que depois encontraram continuidade nos trabalhos da CMBEU, foi subsidiar e impulsionar as discussões e pesquisas sobre os problemas da economia brasileira e os meios de fomentar o seu desenvolvimento.

Do lado da política exterior, os instrumentos utilizados indicam que de certa forma repetiu-se, com outras nuances, as diretrizes seguidas pela política econômica, conforme atestado pela orientação geral de acompanhamento da política externa norteamericana e no tratamento da questão da participação do capital estrangeiro na economia brasileira, como o ocorrido em Chapultepec e na questão da exploração de minerais estratégicos. 
De qualquer modo, foi crescendo ao longo da gestão Dutra uma abertura inevitável para a discussão e o questionamento dos benefícios do alinhamento norteamericano e da construção da sua nova ordem internacional para economias periféricas como a brasileira. Além do crescente descontentamento com a diferença de tratamento dispensada à Europa pelo Plano Marshall, crescia a percepção no mundo subdesenvolvido sobre a real natureza da bipolaridade Leste-Oeste diante das necessidades do desenvolvimento dos países atrasados. Para a periferia latinoamericana, essa abertura foi marcada pela criação da CEPAL e a divulgação de seus trabalhos sobre a especificidade histórica do continente e os caminhos para o seu desenvolvimento, provendo os governos da região com o embasamento teórico necessário para fundamentar os processos de industrialização sob a condução estratégica do Estado.

Na realidade, essa abertura teve seus reflexos tanto na equipe econômica quanto na diplomática, como atestado pelos movimentos de ambas as políticas em direção a uma postura mais reivindicatória do apoio efetivo norte-americano à economia brasileira. Nesse sentido, o afastamento desses dois canais de atuação da PIIEB com relação à agenda pró-Estados Unidos se iniciou de forma pragmática, sem existir ainda uma nova concepção sobre como ambos poderiam ser combinados para atuar em prol de uma programação de desenvolvimento econômico.

Portanto, a atuação conjunta das políticas econômica e exterior durante o governo Dutra foi no geral predominantemente complementar, mesmo nos momentos de inflexão, refletindo uma orientação grosso modo comum no que diz respeito ao alinhamento econômico à Washington e os seus interesses na América Latina (não significando necessariamente alinhamento aos princípios declarados de Bretton Woods). Porém, no seio de cada política percebe-se um movimento de crescente contestação à realidade das relações Brasil-Estados Unidos e, principalmente, do significado do conflito Leste-Oeste para o desenvolvimento da periferia, especialmente mais para o final da gestão Dutra. 


\subsection{O SEGUNDO GOVERNO VARGAS (1950-1954): A VELHA FÓRMULA SOB NOVA EQUAÇÃO - MAIS AUTONOMIA, MENOS DEPENDÊNCIA}

\subsubsection{Contextualização}

A eleição de Getúlio Vargas em 1951 levou à revisão do paradigma americanista de Dutra, recuperando a tentativa de seu primeiro governo de construir um quadro de desenvolvimento econômico nacional sob a condução estratégica do Estado. Desse modo, a exemplo da postura adotada em sua primeira gestão, Vargas tentou negociar o alinhamento brasileiro à Washington por apoio ao seu programa de desenvolvimento nacional, evidenciando uma postura de maior autonomia com relação ao governo anterior de Dutra.

No entanto, conforme já ficara evidenciado no período anterior, o pós-guerra não dispunha das mesmas condições favoráveis à barganha com os Estados Unidos que existiam durante os anos da Missão Cooke. Apesar de que, no início de seu governo, os Estados Unidos haviam acabado de aprovar o Act for International Development de 1950, enunciando pela primeira vez a intenção de assistir ao desenvolvimento dos países periféricos por meio de um programa de ajuda técnica e econômica, a posse do presidente republicano Eisenhower em 1953 levou a uma nova postura norte-americana para a América Latina, caracterizada pela redução de gastos e percepção de inexistência de uma "ameaça comunista" no continente. (TAVARES, 2010, p. 17-30)

No que diz respeito à situação doméstica, Vargas herdara uma conjuntura de séria crise cambial e déficit no balanço de pagamentos, acelerado processo inflacionário e desequilíbrio financeiro do setor público. Diante de tal quadro, o recurso aos capitais estrangeiros surgiu como meio para fazer avançar o processo de industrialização brasileira e instalar o setor de base. Em paralelo, um novo perfil político-econômico se delineava na sociedade brasileira nos anos 1950, crescentemente urbano-industrial e mais politicamente participativo, com a ascensão de uma burguesia média e uma classe operária (VISENTINI, 2008, p. 17).

Em decorrência, esta evolução envolveu, conforme Cervo e Bueno (2008), uma polarização crescente entre "nacionalistas" e "liberais" acerca da participação do capital 
estrangeiro em setores da economia nacional e na exploração de minerais estratégicos (como o petróleo), principalmente no âmbito do aparato estatal, mas também com reflexos na opinião pública.

Portanto, o governo Vargas acabou encontrando-se em uma difícil posição, se não impossível, de atender as demandas do desenvolvimento sem ferir o alinhamento aos Estados Unidos, em meio a uma conjuntura externa desfavorável à repetição da política de "autonomia na dependência" empreendida durante a Segunda Guerra, e a uma conjuntura doméstica de polarização crescente entre os setores favoráveis ao americanismo e os defensores de uma postura mais nacionalista. Diante dessas conjunturas, as políticas econômica e exterior buscaram caminhos alternativos à subordinação norte-americana, com intensidades e formatos diferentes, em um comportamento gradualmente mais autônomo em relação à influência de Washington.

\subsubsection{Instrumentos da política econômica}

O eixo da política econômica da PIIEB do segundo governo Vargas pode ser entendida por duas frentes principais: as tentativas de solucionar, ou pelo menos contornar, as restrições ao programa de desenvolvimento impostas pela série crise cambial que acometeu o país; e a construção de um aparato técnico e institucional visando a amparar a concepção e realização de projetos de transformação estrutural da economia, tendo como pilar os trabalhos da Comissão Mista Brasil-Estados Unidos para o Desenvolvimento Econômico (CMBEU).

Proposta no final do governo Dutra, a CMBEU reuniu técnicos de ambos os países e teve como diagnóstico a necessidade de eliminar os estrangulamentos dos setores básicos da economia brasileira, como transporte e energia, para assim criar condições para o desenvolvimento. Para enfrentar esses problemas, a comissão deveria propor projetos a serem submetidos a entidades de financiamento internacional, como o Eximbank e o BIRD, para apoio de um trabalho no qual "capitais públicos e privados tinham função complementar e não antagônica” (MALAN et al., 1977, p. 34).

O recurso ao capital externo fazia-se necessário em decorrência dos sérios problemas nas contas externas que o país enfrentava. Porém, apesar das tentativas de angariar a cooperação dos Estados Unidos, as ações de política econômica 
empreendidas parecem no geral demonstrar uma autonomia crescente perante as orientações de Washington no que diz respeito à promoção dos interesses econômicos nacionais, que nem sempre foram consonantes aos interesses norte-americanos.

Desse modo, na tentativa de conter o déficit externo, a Sumoc definiu em 1951 instruções para que a CEXIM reintroduzisse um regime severo de licenciamento de importações, mas mesmo assim a balança comercial permaneceu negativa, levando ao esgotamento das reservas internacionais e piorando a crise cambial. Este quadro levou o governo a decidir pela restrição das remessas de lucros e dividendos, aprovando sem prévia consulta a Washington o Decreto $\mathrm{n}^{\circ} 30363$ de 1952, que limitou as formas de retorno do capital estrangeiro investido no Brasil (o capital investido deveria retornar de forma parcelada sem exceder $20 \%$ em cada ano, e os rendimentos não poderiam exceder a $8 \%$ do total registrado).

Conforme Malan et al. (1977, p. 34), o Decreto gerou intensos protestos tanto dos Estados Unidos quanto do BIRD, precipitando uma mudança de postura perante as necessidades de financiamento do Brasil. $\mathrm{Na}$ realidade, os autores analisam que o Decreto foi o ápice de uma série de eventos que levaram progressivamente à deterioração das relações com os Estados Unidos, como o não envio de tropas brasileiras à Coréia em 1951, e as propostas de criação do Programa Nacional do Petróleo e da Petrobras no mesmo ano. Assim, logo após sua promulgação, o BIRD suspendeu novos empréstimos ao Brasil até que a questão das remessas fosse sanada:

Até 1952 o Brasil era considerado um promissor candidato para empréstimo pelo Banco. Então determinadas políticas seguidas pelo Governo brasileiro foram consideradas como prejudiciais à credibilidade do Brasil. [...] Os empréstimos declinaram em 1953 e 1954 e foram nulos em 1955-1957. (Mason e Asher, 1973 , p. $657^{79}$ apud MALAN et al., 1977, p. 35)

Ainda na visão dos mesmos autores, a crise cambial de 1951-1953 foi um marco na história econômica brasileira, pois a partir dela até o golpe de 1964 os Estados Unidos, o BIRD e o FMI passaram a insistir na adoção de políticas econômicas ortodoxas de estabilização como requisito para a colaboração financeira. No entanto, tendo em vista as conjunturas aqui trabalhadas, percebe-se que havia outros elementos e interesses específicos decorrentes de conflitos internos dos Estados Unidos que influíram nessa nova lógica, além de outros processos em formação, como a difusão de

\footnotetext{
${ }^{79}$ Mason, E. S. e Asher, R. E. The World Bank since Bretton Woods. Washington D.C., The Brookings Institution, 1973.
} 
formulações alternativas para o desenvolvimento da periferia, o fortalecimento do Terceiro Mundo e as necessidades de ampliação de mercado das transnacionais norteamericanas na nova lógica de acumulação de capital dos Estados Unidos.

No início dos anos 1950 os trabalhos da CEPAL já influenciavam os debates econômicos no Brasil, e ressoavam especialmente entre os membros da Assessoria Econômica de Vargas, presidida por Rômulo de Almeida e composta por técnicos com grande influência junto ao presidente. Conforme Barbosa e Koury (2013, p. 1081), as funções da Assessoria podiam ser divididas em dois tipos principais: a administração econômica de curto prazo; e o planejamento estratégico de longo prazo visando a atacar os principais gargalos da economia de modo a garantir a eficiência econômica e social.

Em específico, a Assessoria Econômica mantinha um estreito diálogo com Furtado, um dos principais colaboradores de Prebisch na CEPAL, que trabalhou para divulgar as formulações sobre a industrialização desenvolvidas pelo órgão e angariar o apoio do governo brasileiro. Nesse sentido, Love (1998, p. 362) aponta que houve um relativo sucesso, com Vargas apoiando em 1951 a transformação da Cepal em agência permanente da ONU, sob a forte oposição dos Estados Unidos.

Desse modo, trabalhando nos bastidores, os técnicos da Assessoria deram substância a muitos projetos do governo e serviram muitas vezes de contraponto à ala "conservadora" do governo que ocupava cargos nos Ministérios da Fazenda e das Relações Exteriores, especialmente no que dizia respeito ao planejamento de longo prazo do desenvolvimento econômico nacional, em uma relação de muitos confrontos, mas também de muitos diálogos. (BARBOSA E KOURY, 2013, p. 1087-1088)

Por conselho da Assessoria, Tavares (2010, p. 41) aponta que foi criada em 1951, a Comissão de Desenvolvimento Industrial (CDI), com o objetivo de estudar e propor medidas para o estabelecimento de novas indústrias e a ampliação das existentes. Subordinada ao Ministério da Fazenda, a comissão era composta por subcomissões destinadas cada uma a estudar setores específicos da economia, e que mais tarde deram origem aos grupos executivos do Plano de Metas de Juscelino Kubistchek.

Mesmo com esses reveses, os Estados Unidos ainda tinham especial interesse na exploração dos minerais estratégicos brasileiros, o que levou à visita oficial do Secretário de Estado Dean Acheson ao Brasil em 1952. Foi quando a CMBEU aprovou 41 projetos a serem financiados em sua maior parte pelo Eximbank e pelo BIRD, com a contrapartida de fornecimento de minerais estratégicos pelo Brasil aos Estados Unidos e da assinatura do Acordo Militar Brasil-Estados Unidos. (Cervo e Bueno, 2008, p. 279) 
Conforme Tavares (2010, p. 19-20), esses 41 projetos da CMBEU previam um total de US\$ 392 milhões para a sua realização, dos quais a maior parte seria destinada ao setor de transportes (56\%) e o restante distribuído entre os setores de energia elétrica (3\%), agricultura (6\%) e indústrias básicas (5\%). No entanto, logo ficou claro que a aprovação pela CMBEU era condição apenas necessária, não suficiente para a liberalização de recursos pelo Eximbank e pelo BIRD, que os condicionaram à adesão dos princípios econômicos recomendados pelo FMI.

De sua parte, o governo propôs no mesmo ano o Plano de Reabilitação Econômica e Reaparelhamento Industrial, aproveitando os trabalhos técnicos conduzidos pela CMBEU, e criou o Fundo de Reaparelhamento Econômico (FRE), visando a prover os recursos necessários ao plano. Criou também o Banco Nacional de Desenvolvimento Econômico (BNDE) por meio da Lei n ${ }^{\circ} 1628$ de 1952, com o objetivo de gerenciar a aplicação desses recursos, constituindo-se no principal agente financiador e executor do Plano de Reaparelhamento Econômico:

A criação do BNDE foi um passo decisivo para o desenvolvimento do capitalismo brasileiro, quer se analise do ponto de vista do aporte de recursos financeiros, quer do papel que ele teve na formação de uma burocracia moderna, apta a elaborar estudos e a operar novos instrumentos essenciais para a promoção do desenvolvimento econômico. (TAVARES, 2011, p. 21)

Portanto, o BNDE deveria gerenciar não apenas recursos externos, mas também internos, consubstanciando-se como uma instância mediadora "entre o Estado, o setor privado nacional e as entidades internacionais de financiamento" (Martins, 1975, p. 391), uma novidade no rol de instrumentos de ação estatal. Na realidade, segundo Tavares (2010, p. 22), a criação do BNDE fez parte de um movimento do Estado brasileiro promovido por Vargas que se iniciara ainda no Estado Novo. Em essência, foi um movimento de capacitação do Estado como agente econômico, formando e ampliando quadros técnicos e institucionais, com a criação de instituições e empresas estatais como a Companhia Vale do Rio Doce e a Fábrica Nacional de Motores (1942), a Companhia Siderúrgica Nacional (1943) e a Companhia Hidroelétrica do São Francisco (1945). Em seu segundo governo, além do BNDE e do Fundo Federal de Reaparelhamento Econômico, Vargas criou ainda a Petrobras em 1953 e propôs a constituição da Eletrobrás em 1954, tendo ainda formado o CDI e suas subcomissões de estudos setoriais. (TAVARES, 2010, p. 22) 
Nos seus primeiros anos de atuação, o BNDE firmou um importante convênio de pesquisa com o Instituto Brasileiro de Economia da Fundação Getúlio Vargas para a produção de estatísticas referentes às contas nacionais; e outro com a CEPAL, que levou à constituição do grupo misto CEPAL-BNDE, cuja missão foi introduzir o planejamento na economia brasileira em prol do seu desenvolvimento industrial. (TAVARES, 2010, p. 25-27)

Em 1953, a situação cambial brasileira se deteriorou ainda mais, resultando no acúmulo de vultosos atrasos comercias. Para aumentar as exportações e reduzir a propensão a importar, o governo promulgou a Lei $\mathrm{n}^{\circ} 1807$ de 1953 (Lei do Mercado Livre), que instituiu cinco taxas de câmbio para exportações e duas para importações. Em seguida, a Sumoc baixou a Instrução ${ }^{\circ} 70$, que restabeleceu o monopólio cambial do Banco do Brasil e substituiu o controle quantitativo das importações pelo sistema de leilões. Este sistema dividiu as importações em 5 categorias por "grau de essencialidade", havendo uma taxa de câmbio sem sobretaxa para as importações "especiais", uma taxa com sobretaxa fixa para as importações do governo e outra taxa com sobretaxa variável (segundo lances feitos em bolsa) para as demais importações.

Ainda neste contexto de forte deterioração cambial e restrição externa, Vargas encaminhou duas medidas duramente opostas pelos Estados Unidos: a de criação da Petrobras em 1953, e o Decreto-Lei n 34859 do início de 1954, que limitou a 10\% a remessa de lucros do capital estrangeiro ao exterior. Em paralelo, em 1953 o presidente Eisenhower tomou posse nos Estados Unidos, conferindo uma nova postura norteamericana em relação ao Brasil e à América Latina. Neste novo quadro, os Estados Unidos encerraram unilateralmente os trabalhos da CMBEU e substituíram definitivamente a política de colaboração econômica entre governos por uma de ênfase na participação de empresas privadas, isto é, de descomprometimento oficial norteamericano com o desenvolvimento brasileiro e encorajamento aos fluxos de capitais privados.

Portanto, os instrumentos da política econômica de inserção internacional da economia brasileira deste período a serem destacados são:

- os trabalhos da Comissão Mista Brasil-Estados Unidos sobre os pontos de estrangulamento da economia brasileira, prevendo a ação conjunta de capitais públicos e privados; 
- a criação da Comissão de Desenvolvimento Industrial (Decreto ${ }^{\circ} 29.086$ de 1951), para estudar e propor medidas para o estabelecimento de novas indústrias e a ampliação das existentes;

- as instruções da Sumoc para fortalecer o controle das importações por critérios de essencialidade;

- apoio à transformação da CEPAL em agência permanente da ONU em 1951;

- a aprovação de 41 projetos da CMBEU em 1952 com a contrapartida de fornecimento de minerais estratégicos pelo Brasil aos Estados Unidos (assinatura do Acordo Militar Brasil-Estados Unidos em 1953);

- o Decreto n 30363 de 1952, de limitação das formas de retorno do capital estrangeiro investido no Brasil;

- o Plano de Reabilitação Econômica e Reaparelhamento Industrial de 1952, com a criação do Fundo de Reaparelhamento Econômico;

- a Lei no 1628 de 1952, de criação do Banco Nacional de Desenvolvimento Econômico;

- o convênio de pesquisa BNDE-Instituto Brasileiro de Economia da Fundação Getúlio Vargas (produção de estatísticas das contas nacionais);

- o convênio de pesquisa CEPAL-BNDE e a constituição do grupo misto CEPAL-BNDE (trabalhos e estudos para o planejamento econômico do processo de desenvolvimento brasileiro);

- a Lei n 1807 de 1953 (Lei do Mercado Livre) de instituição de diferentes taxas de câmbio visando a aumentar as exportações e limitar as importações;

- a Instrução Sumoc nº 70 de 1953 (restabeleceu o monopólio cambial do Banco do Brasil e substituiu o controle quantitativo das importações pelo sistema de leilões, que diferenciava as importações em 5 categorias por "grau de essencialidade");

- a Lei no 2004 de 1953, de criação da Petrobras;

- a Lei n ${ }^{\circ} 2308$ de 1954, de criação do Fundo Federal de Eletrificação;

- o Decreto-Lei ${ }^{\circ} 34859$ de 1954 , de restrição a 10\% a remessa de lucros do capital estrangeiro ao exterior. 


\subsubsection{Instrumentos da política externa}

A política externa do segundo governo Vargas foi caracterizada pela tentativa de reproduzir a política de "autonomia na dependência" realizada durante os anos da Segunda Guerra, buscando negociar o alinhamento brasileiro pelo apoio de Washington ao seu desenvolvimento econômico. No entanto, conforme visto, tanto a conjuntura internacional quanto a doméstica mostraram-se bastante diversas das dos anos de guerra, frustrando as expectativas brasileiras e levando a política externa a buscar alternativas ao foco hemisférico até então predominante.

A nova orientação da política externa brasileira em relação ao americanismo de Dutra foi indicada na Mensagem ao Congresso Nacional de Getúlio Vargas para abertura da sessão legislativa de 1951. Nesse discurso, o presidente tomou ciência da formação de um novo panorama internacional que significou novas perspectivas à economia brasileira, sinalizando a necessidade da política externa adaptar seus instrumentos de ação diplomática. Nesse sentido, a atuação junto aos organismos multilaterais de cooperação foi levada ao primeiro plano, em detrimento da diplomacia bilateral entre governos, privilegiando as decisões coletivas e a cooperação multilateral, inclusive como o meio de promover o desenvolvimento nacional.

Além de defender uma diplomacia "parlamentar", o presidente ainda introduziu a noção de que a paz e prosperidade internacional não podem ser sustentadas sob a estrutura desigual da economia mundial. No caso do mundo ocidental, as desigualdades entre os países ricos e a periferia subdesenvolvida teriam um potencial desestabilizador e desagregador que justificaria uma política de cooperação internacional:

O Brasil entende que a situação econômica de emergência não deve interromper, e sim acelerar, os programas de cooperação internacional visando ao seu desenvolvimento econômico, pois esse desenvolvimento é indispensável para que possamos manter a nossa própria cooperação com outros países, e para que não soframos em nossa economia desgastes e limitações de difícil e tardia recuperação. (VARGAS, 1951, p. 20)

No que tange à relação bilateral com os Estados Unidos, Hirst (1990) a avalia como um "diálogo de surdos", em que o Brasil comprometia-se com o alinhamento político-militar a Washington na luta contra o comunismo, esperando o seu apoio ao desenvolvimento brasileiro como reconhecimento; enquanto Washington "priorizava a 
promoção do livre fluxo de seus interesses privados" (p. 2), limitando o apoio direto oficial, o que na realidade apenas atualizava o padrão de relacionamento dependente entre centro e periferia. De acordo com o diagnóstico da autora, a política externa de Vargas teve duas ênfases principais: "seu caráter nacionalista e a expectativa de obter uma maior cooperação econômica do governo norte-americano" (HIRST, 1990, p. 6). Neste sentido, “a articulação entre a cooperação político militar e econômica era percebida como o caminho a ser explorado" (HIRST, 1990, p. 8) para angariar o apoio norte-americano.

Destarte, em 1952, como parte de sua estratégia de utilizar o apoio latinoamericano para legitimar a Guerra da Coréia, os Estados Unidos assinaram acordos militares com sete países do continente (os demais sendo considerados "governos rebeldes"), entre eles o Brasil, em que Washington se comprometia a fornecer assistência militar, e as nações latino-americanas signatárias a fornecer materiais estratégicos, restringindo ainda o comércio da região com o bloco soviético. No entanto, nem o Acordo Militar, nem o Acordo Atômico renovado em 1951, se consubstanciaram em um comprometimento oficial de Washington com as demandas do desenvolvimento brasileiro. (Hirst, 1990, p. 4-5)

Por outro lado, Hirst (1990, p. 20-21) aponta que nesse período o Brasil começou a buscar maior autonomia em espaços alternativos da estrutura internacional, aproximando-se do mundo subdesenvolvido em temas de interesse comum que não comprometessem a aliança político-militar com os Estados Unidos. Essa aproximação, segundo a autora, visou principalmente abrir novos horizontes econômicos, tendo envolvido para isso a defesa do direito de autodeterminação dos países árabes, africanos e asiáticos, visto que sua independência poderia trazer benefícios comerciais ao Brasil.

No caso da América Latina, a autora aponta que, pelo fato de o continente americano ser considerado "área de influência direta" dos Estados Unidos, a maioria dos países europeus conferia-lhe baixa prioridade em suas agendas político-econômicas, além de a forte presença de Washington condicionar as relações intracontinentais. Esse quadro tinha reflexos nos organismos regionais latino-americanos, em que os entendimentos de Washington eram colocados aos países da região, como a OEA. A grande exceção foi a CEPAL, órgão em que o Brasil pode se aproximar dos demais países latino-americanos por meio de discussões e trabalhos técnicos sobre o desenvolvimento do continente. (HIRST, 1990, p. 22-23) 
Desse modo, também na política externa referente à América Latina manifestava-se a diferença de posturas política e econômica. Na política, o alinhamento ficou evidenciado pelo apoio brasileiro aos Estados Unidos por ocasião da Revolução Boliviana de 1952 e da intervenção norte-americana na Guatemala em 1954. Na econômica, as tentativas de aproximação com o resto da America Latina deram-se por meio de iniciativas como a expansão da estrada de ferro nas fronteiras com o Paraguai e a Bolívia; a intensificação dos contratos econômicos com a Venezuela, Colômbia e Chile; e o Acordo Comercial Brasil-Argentina de 1953. (Hirst, 1990, p. 24-41)

Assim, ressaltamos como instrumentos da política externa de inserção internacional da economia brasileira neste período:

- a orientação genérica pelo americanismo;

- a mensagem presidencial de Vargas ao Congresso Nacional para abertura da sessão legislativa de 1951;

- o Acordo de Assistência Militar Recíproca de 1952 (fornecimento de materiais estratégicos aos EUA e restrição do comércio com o bloco soviético em troca de assistência militar norte-americana);

- a aproximação do mundo subdesenvolvido em temas de interesse comum que não comprometessem a aliança político-militar com os Estados Unidos, visando principalmente abrir novos horizontes econômicos;

- a aproximação dos países latino-americanos por meio das discussões da CEPAL e de iniciativas bilaterais (expansão da estrada de ferro nas fronteiras com o Paraguai e a Bolívia; assinatura de contratos econômicos com a Venezuela, Colômbia e Chile; e o Acordo Comercial Brasil-Argentina de 1953).

\subsubsection{Comparação e resultados}

Apesar das tentativas de angariar o apoio de Washington ao programa de desenvolvimento brasileiro, especialmente por meio da colaboração político-militar, percebe-se um movimento do segundo governo Vargas em direção à busca de outros meios de garantir seus objetivos econômicos e ganhar maior autonomia na busca dos interesses nacionais. Essa tendência deu-se de forma crescente na medida em que também aumentava a percepção e o debate nacional sobre os reais interesses norte- 
americanos e as condições oferecidas pela estrutura centro-periferia às demandas da industrialização brasileira.

De certo modo, tal tendência foi promovida por ambas as frentes, a da política econômica e a da política externa, porém em intensidades diferentes, respeitadas as particularidades de cada âmbito de atuação governamental e as condições específicas inerentes de suas naturezas individuais. No caso da política econômica, foi evidente a mudança de postura do segundo governo Vargas em comparação à gestão Dutra, colocando o que era percebido como os interesses da economia brasileira em primeiro lugar e a despeito das contrariedades geradas com os Estados Unidos. Foi o caso da regulamentação das remessas de capitais para o exterior (Decretos n 30363 de 1952, e n 34859 de 1954), e das propostas de criação do Programa Nacional do Petróleo e da Petrobras, iniciativas tomadas na contramão dos interesses norte-americanos.

Nesse sentido, seguindo a constatação de Tavares (2010), os instrumentos da política econômica parecem corroborar a existência de um movimento de capacitação do Estado como agente planejador e condutor do processo de desenvolvimento, formando e ampliando quadros técnicos e institucionais no âmbito do sistema estatal, como o BNDE e o CDI, e inclusive estabelecendo parcerias internacionais, como a CMBEU e o grupo CEPAL-BNDE. Talvez este tenha sido um dos legados mais importantes de seu governo, quando além do aparelhamento institucional e técnico do Estado, técnicas modernas de análise econômica foram introduzidas e importantes diagnósticos sobre a economia brasileira foram realizados. Em especial, destaca-se o apoio demonstrado pelo governo Vargas ao fomento de estudos e pesquisas sobre a economia brasileira e sobre o papel do Estado na condução do desenvolvimento, expresso desde a constituição de grupos de estudos setoriais até a criação de instituições como o BNDE.

No caso dos instrumentos da política externa, parece ser confirmada a constatação de Hirst (1990) de que o Brasil buscou negociar o apoio de Washington ao seu programa de desenvolvimento por meio da cooperação político-militar, assumindo ainda uma nova postura reivindicatória diante da diferença de tratamento conferido pelos norte-americanos à Europa com o Plano Marshall. Apesar de o alinhamento brasileiro no âmbito político-militar ter sido praticamente completo, iniciou-se neste período um movimento de maior autonomia na atuação internacional do Brasil em questões que não interferissem em sua aliança político-militar com os Estados Unidos. 
Nesse sentido, aproximando-se do mundo subdesenvolvido por meio da atuação multilateral e bilateral, as delegações brasileiras demonstraram crescente articulação nos fóruns de discussão internacional na defesa do desenvolvimento dos países da "periferia" e na busca de parcerias econômicas que não interferissem com a aliança norte-americana. Isto é, a política externa deste período indica o início de um movimento de relativo distanciamento da dependência hemisférica dos Estados Unidos, ainda entravado principalmente pela necessidade dos capitais norte-americanos para os projetos de industrialização brasileira e pela expectativa de apoio ao desenvolvimento nacional em reconhecimento à cooperação político-militar demonstrada no período.

Portanto, durante o segundo governo Vargas, parece ter havido um movimento de inflexão do americanismo, ainda sem rompimento, no caso de ambas as políticas econômica e externa. Este afastamento parece ter sido mais intenso na política econômica, em que alguns dos instrumentos utilizados foram abertamente contrários aos interesses dos Estados Unidos, gerando tensões e embates entre os dois países - como foi o caso da criação da Petrobras e do Decreto n ${ }^{\circ} 30363$ de 1952. No caso da política externa, o distanciamento foi mais tímido, tendo em vista que a diplomacia brasileira buscou maior autonomia apenas nas questões que não prejudicassem a aliança políticomilitar com Washington, âmbito em que o alinhamento foi quase que completo. Mesmo assim, houve um movimento de relativo distanciamento da dependência norteamericana, por meio de uma atuação mais intensa nos fóruns multilaterais e da aproximação a outros países, ainda que sem ameaçar os interesses da aliança político e militar com Washington.

Ou seja, ambos os instrumentos das políticas econômica e externa do segundo governo Vargas parecem apontar para um movimento de tentativa para exercer maior autonomia perante a dependência e influência norte-americana, buscando para isso aumentar a capacidade do Estado para gerenciar a economia e identificar oportunidades alternativas aos Estados Unidos no âmbito internacional. Especialmente na política econômica ficou evidente esse movimento, em que o apoio norte-americano à economia nacional foi buscado sem subordinar os interesses do desenvolvimento brasileiro aos de Washington e suas empresas transnacionais. De outro lado, as ações da política externa empreenderam uma tendência de busca de alternativas à dependência econômica norteamericana, porém restringindo-se às questões que não produzissem enfrentamentos diretos com os Estados Unidos, em uma postura mais contida. De qualquer modo, o movimento geral foi de construção de um Estado crescentemente capacitado para 
controlar e programar o desenvolvimento econômico, e também crescentemente consciente da existência de opções alternativas aos Estados Unidos para construir um cenário internacional mais propício ao florescimento da economia brasileira.

\subsection{O GOVERNO KUBISTCHEK (1956-1961): A NOVA DEPENDÊNCIA COMO CONSTRANGIMENTO PARA A AUTONOMIA}

\subsubsection{Contextualização}

Os anos 1950 assistiram a uma série de transformações na estrutura e lógica de funcionamento da economia-mundo capitalista, com a progressiva descolonização dos continentes africano e asiático, a transformação organizacional preconizada pelas grandes corporações norte-americanas e a consolidação de uma nova dinâmica de acumulação mundial liderada pelos Estados Unidos.

Em meados da década de 1950, a crise cambial e do balanço de pagamentos que acometia o país se intensificara, com o Brasil enfrentando uma séria escassez de divisas para sustentar a entrada de bens de capital e matérias-primas necessários para continuar o seu processo de industrialização. Segundo Tavares (1975, p. 131-132), a industrialização brasileira estava ingressando em um novo ciclo caracterizado pela necessidade de novas tecnologias e de grandes volumes de investimentos, exigindo grande mobilização e centralização de capital pelo Estado, o que facilitou a forte presença do capital estrangeiro nesta etapa do processo de industrialização nacional.

Em paralelo, desde o fim da Segunda Guerra Washington mostrava um comprometimento crescente com os interesses de expansão internacional das corporações norte-americanas, forçando o recurso aos investimentos privados na América Latina no lugar dos auxílios financeiros oficiais e exigindo a necessidade de estabilização monetária dos países do continente (PINHEIRO, 2004, p. 31). Além disso, a expansão transnacional das grandes corporações norte-americanas, junto à recuperação da Europa e do Japão, levara ao crescimento da competição econômica entre os países industrializados, com o esgotamento dos mercados e encarecimento de 
custos, levando-os a competir por oportunidades e fontes de matérias-primas nos países da periferia. (Evans, 1980, p. 36)

De outro lado, fortalecia-se o movimento do Terceiro Mundo em contestação à lógica enrijecedora da economia-mundo capitalista, conforme era evidenciado pela progressiva descolonização dos continentes africano e asiático, significando a perda pelos países industrializados do controle total sobre esses mercados e suas fontes de insumos e matérias-primas; a Conferência de Bandung de 1955, que reuniu países africanos e asiáticos para discutir o papel do Terceiro Mundo e promover a cooperação entre países subdesenvolvidos; e a formação do Movimento dos Países Não-Alinhados em 1961, composto por países em desenvolvimento que manifestaram neutralidade perante o conflito Leste-Oeste para unirem-se em prol do desenvolvimento econômico do Terceiro Mundo.

No caso da América Latina, os estudos da CEPAL proviam apoio técnico e fundamentação teórica para o planejamento estatal na condução do desenvolvimento econômico dos países latino-americanos. Conforme Barbosa (2013, p. 222-223), a partir de 1951, a recém-independente e não mais provisória CEPAL consolidou um corpo substancial de técnicos e passou a agregar novas funções além de elaborar relatórios de pesquisa, como o oferecimento de treinamentos para quadros governamentais latinoamericanos e de assistência técnica para as políticas de industrialização dos governos da região. No Brasil, cabe destacar ainda a criação do Instituto Superior de Estudos Brasileiros (ISEB) em 1955, como fórum de discussões e estudos acerca do desenvolvimento e do papel do Estado em sua condução.

Como aponta Pinheiro (2004, p. 34), a criação e consolidação desses espaços de discussão sobre o desenvolvimento de países "atrasados", aliada ao fortalecimento do movimento do Terceiro Mundo em contestação à hierarquia desigual da economiamundo capitalista, propiciaram o início do desenvolvimento nos anos 1950 de um novo paradigma da política exterior brasileira, pautado pela diversificação das relações exteriores do Brasil, em contraste ao americanismo anterior. 


\subsubsection{Instrumentos da política econômica}

O grande problema do início do governo Kubistchek foi a escassez de divisas necessárias para importar os bens de capital e as matérias-primas exigidas pelo processo de industrialização. Visando a solucionar a restrição externa e programar a ação governamental em prol do desenvolvimento industrial, Kubistchek criou o Conselho do Desenvolvimento em seu primeiro ano de governo, que ficou encarregado de elaborar e gerenciar um plano de desenvolvimento econômico que articulasse os setores público e privado na consecução de seus objetivos.

O recém-empossado presidente havia endossado a visão de "programação" estatal do desenvolvimento proposta pela CEPAL, que defendia que, tendo em vista as eventuais dissonâncias entre os interesses dos empresários e os da coletividade, o Estado deveria solucionar os pontos de estrangulamento da economia e fomentar os seus polos de crescimento, de modo a reduzir a heterogeneidade setorial. Conforme Love (1998, p. 372-373), o presidente endossara também as teses cepalinas sobre a deterioração dos termos de troca e a natureza do desequilíbrio externo, defendendo a industrialização como solução para substituir as importações, diversificar as exportações e absorver o excedente de trabalho agrícola.

Baseando-se nos diagnósticos elaborados pelo Grupo Misto CEPAL-BNDE (1953-1955) e pela CMBEU (1950-1953), o Conselho do Desenvolvimento apresentou no mesmo ano o Plano de Metas, que se concentrou em atacar os problemas da infraestrutura econômica e na modernização e ampliação do parque industrial. Nesse sentido, o Plano dividia seus objetivos em cinco setores principais - energia, transporte, alimentação, indústria de base e educação -, consubstanciados em trinta metas a serem implantadas ao longo de cinco anos. Segundo Oreinstein e Sochaczewski (1990, p. 177), a maior ênfase seria dada ao setor de infraestrutura (energia e transporte), para o qual seriam destinados $71,3 \%$ dos recursos, e ao da indústria de base, que contaria com $22,3 \%$.

Durante a consecução do Plano de Metas, grupos executivos foram sendo criados para formular e coordenar os programas setoriais de modo a tornar complementares os investimentos nacionais e estrangeiros, públicos e privados, à 
semelhança das subcomissões de trabalho da CDI do segundo governo Vargas ${ }^{80}$. Na realidade, conforme Tavares (2010, p. 22-28), desde o início dos anos 1950 o governo Vargas preconizara uma política de desenvolvimento que avançou na modernização do Estado, aumentou sua capacidade de coordenação com a criação de um novo aparato institucional e legal, e inovou na obtenção de recursos para promover projetos, como foi o caso dos fundos de empréstimos compulsórios dos contribuintes do Imposto de Renda criados para viabilizar as atividades do BNDE. Nesse sentido, a formação de conselhos e grupos de estudos pelo governo Kubitschek veio a ampliar a capacidade de coordenação do Estado, de modo a articular agentes públicos e privados na determinação das políticas setoriais e amadurecer o tipo de gestão que fora iniciado pelo segundo governo Vargas.

Para incentivar a iniciativa privada nacional, o Plano trouxe medidas como a reserva de mercado para a produção nacional (Lei do similar nacional) e o oferecimento de crédito subsidiado pelo BNDE e pelo Banco do Brasil (Oreinstein e Sochaczewski, 1990, p. 179). Além disso, ofereceu um câmbio preferencial para a importação de bens de capital em setores especiais (automobilística e naval), por meio da Instrução $\mathrm{n}^{\circ} 113$ da Sumoc de 1957, que instituiu um sistema de taxas múltiplas de câmbio para incentivar os investimentos privados na indústria.

O estímulo ao capital privado estrangeiro também foi contemplado. Pela mesma Instrução $\mathrm{n}^{\circ}$ 113, a Carteira de Comércio Exterior (Cacex) foi autorizada a emitir licenças de importação de equipamentos sem cobertura cambial para empresas estrangeiras associadas ao capital nacional, sob a forma de investimento direto estrangeiro. Além de facilitar a importação de bens de capital e diminuir a burocracia para a entrada de capital externo, esse instrumento concedia um considerável subsídio implícito ao capital privado estrangeiro, pois os equipamentos importados eram contabilizados no ativo como investimento direto a uma taxa de câmbio livre, enquanto a remessa de lucros era feita por uma taxa de câmbio preferencial. Para Tavares (2010, p. 68-69), a instrução foi o principal instrumento da política de atração do capital estrangeiro para o Brasil no período, tendo facilitado o importante crescimento dos

\footnotetext{
${ }^{80}$ Dentre eles, Tavares (2010, p. 50) destaca os Grupos Executivos: da Indústria Automobilística (Geia) de 1956; o da Indústria da Construção Naval (Geicon) de 1958; os da Indústria Mecânica Pesada (Geimape), para Aplicação de Computadores Eletrônicos (Geace), e para Incrementar e Reestruturar o Sistema de Ensino Técnico-Científico-Profissional (Enape), de 1959; e o de Assistência a Média e a Pequena Empresa (Geampe), de 1960.
} 
investimentos diretos estrangeiros nos setores de alumínio, cimento, indústria automobilística e construção naval.

Um dos maiores empecilhos à consecução do Plano de Metas foi o seu financiamento, em um contexto de desequilíbrio externo e escassez de divisas. Conforme Oreinstein e Sochaczewski (1990, p. 178), os recursos proviriam majoritariamente do Estado brasileiro ( $50 \%$ dos recursos), complementado pelo setor privado (35\%) e por empréstimos de agências internacionais (15\%). Segundo esses autores, boa parte dos vultosos gastos do Plano de Metas foi coberta por meio de empréstimos do Banco do Brasil ao Tesouro, resultando em um quadro de forte pressão inflacionária e de expansão do endividamento do setor público. Com sua capacidade de continuar financiando o Plano comprometida, o governo buscou angariar recursos do governo norte-americano ou de agências internacionais, recebendo em 1958 uma missão do FMI para avaliar a possibilidade de um empréstimo externo de US\$ 300 milhões para cobrir os investimentos previstos no Plano.

Sob orientação do FMI, foi elaborado um Programa de Estabilização Monetária caracterizado por medidas conservadoras de rígido controle orçamentário e combate à expansão da base monetária, como o aumento de impostos, a contenção dos salários, o controle das linhas de crédito do Banco do Brasil e a eliminação dos subsídios. Este programa rapidamente sofreu grande desgaste, além de dificultar a continuidade do Plano de Metas e enfraquecer as bases de sustentação política e social do governo. Em 1959, com a crise internacional do café e a piora da situação fiscal, o governo acabou optando pela suspensão do Programa de Estabilização, rompendo com o FMI e com o Banco Mundial. No mesmo ano, a Sumoc determinou a liberação, pela Instrução ${ }^{\circ} 167$, das exportações de manufaturados pelo mercado livre, completando-a logo em seguida com a Instrução $n^{\circ} 192$, que acabou transferindo todos os tipos de exportações para o mercado livre, com a exceção de café, cacau, óleo mineral cru e mamona.

Portanto, a política econômica de inserção internacional da economia brasileira do governo Kubistchek caracterizou-se por um grande esforço de mobilização do Estado e do capital privado estrangeiro e nacional em torno do Plano de Metas, em um contexto de desequilíbrio no balanço de pagamentos, crise internacional do café e escassez de divisas. As tentativas de angariar recursos para o plano foram caracterizadas pelo forte endividamento do setor público, que além de promover seus próprios investimentos, concedeu amplos empréstimos e subsídios ao setor privado nacional e 
estrangeiro. Em especial, o investimento direto estrangeiro foi largamente beneficiado, ingressando com peso em diversos setores industriais brasileiros.

Se de um lado instalou-se com sucesso parte da indústria de base e diversificouse o setor de bens de consumo duráveis, promovendo um ciclo de acumulação de capital endogenamente sustentado pelo Estado brasileiro; de outro lado aprofundaram-se desequilíbrios estruturais da economia brasileira, piorando as desigualdades sócioregionais e as contas fiscais e externas do governo, ao mesmo tempo em que se permitia uma ampla participação do capital estrangeiro em importantes setores industriais. Montava-se assim o quadro que viria a caracterizar o conturbado período de instabilidade política e social dos governos Jânio Quadros e João Goulart, em que cresceram as restrições de ordem interna ao exercício de uma maior autonomia da economia brasileira.

Em suma, destacamos como instrumentos da política econômica que se relacionaram à inserção internacional da economia brasileira:

- a criação do Conselho do Desenvolvimento em 1956;

- o Plano de Metas de 1956-1961 (solucionar problemas da infraestrutura econômica e modernizar e ampliar o parque industrial por meio da aliança Estado, capital privado nacional e estrangeiro);

- o desenvolvimento de maior capacidade de coordenação, elaboração e execução de projetos setoriais pelo BNDE e medidas de alocação de recursos financeiros ao BNDE:

- Lei no 2973 de 1956: recursos do Adicional do Imposto de Renda;

- Lei no 2975 de 1956: 16\% das quotas do Imposto Único sobre Combustíveis e Lubrificantes;

- Lei no 3381 de 1958: recursos do Fundo de Marinha Mercante;

- Lei nº 3421 de 1958: recursos do Fundo Portuário Nacional

- a criação de grupos executivos para formular e coordenar os programas setoriais e articular os investimentos nacionais e estrangeiros;

- o oferecimento de crédito subsidiado pelo BNDE e pelo Banco do Brasil ao capital privado nacional;

- a Instrução $n^{\circ} 113$ de 1957 da Sumoc, de criação do sistema de taxas múltiplas de câmbio para incentivar os investimentos privados na indústria e concessão de subsídios ao capital privado estrangeiro por meio das licenças de importação de equipamentos sem cobertura cambial, sob a forma de investimento direto estrangeiro; 
- a elaboração do Programa de Estabilização Monetária do FMI em 1958;

- a suspensão do Programa de Estabilização e o rompimento com o FMI e com o Banco Mundial em 1959;

- as Instruções $n^{\circ} 167$ e $n^{\circ} 192$ da Sumoc de 1959 (transferiu todos os tipos de exportações para o mercado livre, com algumas exceções).

\subsubsection{Instrumentos da política externa}

Apolítica externa do governo Kubistchek apoiou o chamado "desenvolvimento associado", caracterizando-se como uma diplomacia hemisférica que no geral promoveu o alinhamento aos Estados Unidos também no plano econômico, não se restringindo como o governo anterior ao âmbito político-militar. Nas palavras de Pinheiro (2004), esta política externa "foi marcada por avanços e recuos, posto que conjugava, nas palavras de Gerson Moura, a 'gestação de formulações e posições de independência em meio à reafirmação de posições de alinhamento"” (p. 32).

A postura norte-americana em relação às necessidades do desenvolvimento latino-americano, desigual perante os recursos destinados à Europa e Japão pelo Plano Marshall, acabou alimentando o antiamericanismo e antiimperialismo na América Latina, piorando as relações da potência com muitos países do continente. Para Cervo e Bueno (2008, p. 290), Kubistchek aproveitou-se desse quadro para sugerir aos Estados Unidos uma revisão do ideal pan-americanista, lançando em 1958 a Operação PanAmericana (OPA), a principal iniciativa diplomática de seu governo.

A proposta era que os Estados Unidos assumissem um compromisso político com a erradicação do subdesenvolvimento latino-americano, apoiando as políticas e iniciativas autônomas da região, e alocando investimentos oficiais, sob o argumento de que tal compromisso corresponderia aos próprios interesses americanos, posto que o subdesenvolvimento contribuía para a instabilidade política e o baixo nível da população, sendo um estímulo aos problemas sociais e à instalação do comunismo nesses países. (CERVO E BUENO, 2009, p. 289-292)

$\mathrm{Na}$ avaliação de Rodrigues (1966), a OPA confirmou a regionalização da política externa brasileira e o alinhamento com os Estados Unidos e sua política externa. No entanto, o autor ressalva que a iniciativa teve o aspecto positivo de "ligar as 
necessidades internas às diretrizes internacionais, mostrando que a política internacional podia e devia ser um instrumento nacional de desenvolvimento econômico" (RODRIGUES, 1966, p. 66). Apesar de não ter conseguido o comprometimento oficial norte-americano com o desenvolvimento da região, Pinheiro (2004, p. 31-32) destaca que a OPA auferiu o atendimento a uma reivindicação antiga dos países da América Latina pela criação de uma instituição regional de financiamento, com o Banco Interamericano de Desenvolvimento (BID) sendo criado pelos Estados Unidos em 1959.

$\mathrm{Ou}$ seja, se em um primeiro momento a política externa de Kubistchek intensificara o alinhamento aos Estados Unidos, especialmente no plano econômico, na medida em que as restrições financeiras ao avanço do Plano de Metas cresciam, aumentava também a percepção e o inconformismo com a insuficiência do apoio oficial norte-americano e com a rigidez da estrutura centro-periferia. Em especial, a deterioração dos preços internacionais do café penalizava durante a balança comercial brasileira, levando à intensificação das tentativas brasileiras nos fóruns multilaterais de solucionar o problema da deterioração dos termos de troca e da estabilidade do preço internacional de bens primários.

Nesse sentido, apesar de a OPA ter reforçado o foco regional e centralizado a política externa brasileira nos Estados Unidos, a iniciativa constituiu também um instrumento da diplomacia nacional pelo desenvolvimento, na tentativa de sensibilizar Washington a apoiar as economias latino-americanas. Na medida em que não surgiu efeito, foi crescendo o reconhecimento da necessidade de diversificar e ampliar os mercados de exportação do país, em uma tímida conscientização das limitações dadas pelo foco hemisférico da diplomacia nacional. Destarte, a política externa brasileira começou a empreender algumas iniciativas de diversificação, mais para o final da gestão Kubistchek, como o restabelecimento das relações comerciais com a URSS em 1959, firmando um acordo de compra de café brasileiro e venda de trigo e petróleo soviéticos, e a Operação Brasil-Ásia do mesmo ano, visando a aproximação econômica com o continente.

Nos fóruns multilaterais, Cervo e Bueno (2008, p. 295-300) ressaltam que as delegações brasileiras lutaram pela estabilidade do preço internacional de bens primários, visando deter a deterioração dos termos de trocas e denunciando as injustiças do comércio internacional. Como exemplos, os autores apontam a atuação brasileira no GATT por ocasião da criação do Mercado Comum Europeu em 1957 e o discurso do embaixador Walter Moreira Sales em 28 de janeiro de 1960 em Nova York. Nesse 
discurso, o brasileiro fez um balanço das relações econômicas Brasil-Estados Unidos pós-Segunda Guerra para mostrar que, apesar de Volta Redonda e outros programas de apoio econômico, as relações econômicas entre os dois países foram desiguais e negativas para o Brasil, tendo em vista que as exportações norte-americanas entre 1949 e 1958 haviam crescido muito mais que as suas importações de produtos brasileiros.

De certa forma, ensaiava-se timidamente retomar o movimento iniciado no segundo governo Vargas em direção à formação de um "novo paradigma das relações exteriores brasileiras" (PINHEIRO, 2004, p. 34), mais alinhado à conjuntura internacional de enfraquecimento da bipolaridade Leste-Oeste e fortalecimento da clivagem Norte-Sul, conforme evidenciado pela libertação das colônias africanas, pela Revolução Cubana de 1959 e pela formação do Movimento dos Países Não-Alinhados em 1961.

Entretanto, esta retomada foi obstada pela incapacidade do governo Kubistchek de abarcar esses novos elementos em sua política externa, que permaneceu restrita pelo foco hemisférico da OPA e pela expectativa de apoio norte-americano. Em especial, o país passou ao largo do processo de libertação das nações afro-asiáticas entre 1958 e 1960, com a diplomacia brasileira acompanhando a postura dos países colonialistas nas discussões da ONU sobre a África Negra e a descolonização asiática, não condenando ativamente o colonialismo e mantendo os laços especiais com Portugal. (Cervo e Bueno, 2008, p. 295-306)

Mesmo quando em 1960 o Brasil reconheceu os 17 novos Estados africanos, defendendo o princípio da autodeterminação dos povos e apoiando essas nações no movimento do Terceiro Mundo nos organismos internacionais, não houve uma clara defesa do anticolonialismo, nem rompimento com a postura de Portugal. Para Rodrigues (1982, p. 242-244), apesar da "explosão da independência africana" e de suas implicações para o Brasil, a política externa do governo Kubistchek não previu objetivos explícitos nem ações significativas em relação ao continente, limitando-se a reconhecer os países recém-independentes e a promover missões diplomáticas:

A OPA obscureceu o mais importante fenômeno do processo histórico mundial, entre 1958-1960: a liberdade africana. Vivemos alheios ao processo histórico mundial [...]. O Governo de Juscelino Kubistchek desconheceu, quer no campo de sua ação própria, quer nas Nações Unidas, o caminho da liberdade africana, apoiou toda conduta lusitana, submeteu-se aos interesses das Potências coloniais e limitou-se, encerrados os 
processos de independência dos Estados africanos, a reconhecêlos de jure. (RODRIGUES, 1982, p. 245)

Por fim, em 1960 foi criada a Associação Latino-Americana de Livre Comércio (ALALC, por meio da assinatura do Tratado de Montevideo), visando a promover a estabilidade econômica na região e a ampliação do comércio intrarregional. De certo modo, a criação da ALALC remete a todo um ciclo de discussões que vinha acontecendo desde pelo menos 1953, realizadas principalmente no âmbito das Conferências da CEPAL sobre as vantagens de uma maior integração econômica latinoamericana. Essas discussões eram motivadas pelo diagnóstico de Prebisch contra o fracionamento dos mercados da região e a industrialização individual dos países da América Latina, o que devido aos problemas de escala de mercado, poderia penalizar a acumulação de capital local de cada país e ameaçar o desenvolvimento da região:

A possibilidade de que se perdesse uma parte importante do fruto do progresso técnico por causa do excessivo fracionamento dos mercados era vista como um limite ao desenvolvimento industrial dos países da região. Mas, longe de ser intransponível, uma política clarividente de interdependência econômica poderia remover com grande beneficio recíproco. (PREBISCH, 1949, p. 53).

Assim, os principais instrumentos da política externa de inserção internacional da economia brasileira do governo Kubistchek foram:

- o alinhamento aos Estados Unidos no geral, inclusive no plano econômico, apoiando a abertura ao capital estrangeiro;

- a Operação Pan-Americana de 1958 (OPA): proposta hemisférica que visava ao apoio oficial norte-americano para o desenvolvimento da América Latina;

- a criação do Banco Interamericano de Desenvolvimento de 1959 (BID): instituição regional de financiamento do desenvolvimento latino-americano;

- apoio às posições de Portugal na ONU, sem condenar o colonialismo;

- restabelecimento das relações comerciais com a URSS em 1959, com um acordo de venda de café brasileiro e compra de trigo e petróleo soviéticos;

- reconhecimento da independência de 17 Estados africanos, criação de missões diplomáticas e restabelecimento de Consulados em países africanos;

- Operação Brasil-Ásia em 1959 para aproximação econômica com o continente;

- atuação em organismos multilaterais como a ONU e o GATT em prol do desenvolvimento latino-americano, defendendo a estabilidade do preço internacional de bens primários e denunciando as injustiças do comércio internacional; 
- assinatura do Tratado de Montevideo em 1960, com a criação da Associação Latino-Americana de Livre Comércio (ALALC).

\subsubsection{Comparação e resultados}

Os instrumentos empreendidos pela política econômica e pela política externa da gestão Kubistchek avançaram em alguns elementos preconizados pelo governo anterior de Vargas, mas também recuaram em outros. De certo modo, pareceu confirmar-se, para ambas as políticas econômica e externa, a análise feita por Moura (1991) sobre a política externa de Kubistchek, que teria sido caracterizada pela "gestação de formulação e posições de independência em meio à reafirmação de posições de alinhamento".

Assim, no caso da orientação geral de alinhamento aos Estados Unidos e da expectativa ainda sobrevivente do seu apoio oficial ao desenvolvimento brasileiro, esta foi intensificada, com ambas as politicas econômica e externa empreendendo significativas ações de aproximação à potência norte-americana. Em especial, no que diz respeito à abertura ao capital estrangeiro, houve uma clara inflexão em relação ao segundo governo Vargas. Do lado da política econômica, destacaram-se os incentivos ao investimento direto estrangeiro consubstanciados principalmente pela Instrução $\mathrm{n}^{\circ}$ 113 da SUMOC, quando o capital privado estrangeiro entrou como parte integrante e fundamental do novo ciclo de industrialização; enquanto que do lado da política externa destacou-se a proposta da OPA, que reforçou o foco hemisférico da diplomacia brasileira e o seu pleito pelo apoio oficial de Washington ao desenvolvimento latinoamericano.

Por outro lado, houve também um importante avanço no movimento de aparelhamento do Estado visando a aumentar sua capacidade de gerenciar e programar o desenvolvimento econômico. Nesse sentido, o Plano de Metas foi talvez sua expressão máxima, amparado pela criação dos grupos executivos de estudos setoriais do Conselho do Desenvolvimento e do aparelhamento técnico, financeiro e legal conferido ao BNDE. Desse modo, o Estado brasileiro auferir importantes conquistas na consolidação e diversificação do parque industrial brasileiro, além de manter o crescimento econômico em um contexto de crise cambial e fortes restrições externas. 
O período Kubitschek revelou-se crucial para a estruturação do capitalismo nacional, empreendendo o primeiro grande ciclo endógeno de crescimento impulsionado pelo Estado, com pesados investimentos públicos e o estímulo à iniciativa privada nacional e estrangeira independente do contexto internacional e das restrições externas. No diagnóstico de Tavares (2010, p. 130-132), se no ciclo de industrialização anterior de 1937 a 1954 havia uma aparente autonomia em relação ao capital estrangeiro, esta não se devia a uma postura nacionalista ou a uma hegemonia da burguesia industrial, mas ao fato de que a reinversão dos lucros internos permitia a ampliação da capacidade produtiva. Já a implantação da indústria pesada que caracterizou o novo ciclo de industrialização iniciado pelo governo Kubistchek exigia para a sua realização um Estado capacitado, e um alto volume de investimentos.

Ou seja, parece-nos que os instrumentos da política econômica do período buscaram garantir, a partir das condições internas e externas de cada momento, o ideário do desenvolvimento, sem no entanto se desvencilhar da expectativa de apoio oficial norte-americano. $\mathrm{Na}$ realidade, os instrumentos da política econômica refletiram o quadro que se configurava possível para o governo avançar seu programa de desenvolvimento, sob um entendimento de que o sucesso do novo ciclo de industrialização brasileiro dependia e precisava do recurso ao capital estrangeiro, fosse ele privado ou oficial.

Assim se explica a aparente contradição do ato de ruptura com o FMI e com o seu Programa de Estabilização Monetária em 1959, que no quadro de exacerbação dos desequilíbrios externo e fiscal que acometiam a economia brasileira no período, impossibilitava a adesão às medidas propostas pelo programa sem comprometer seriamente o crescimento econômico e o projeto de desenvolvimento nacional.

Entretanto, a contrapartida do acelerado ciclo de crescimento promovido pelo governo foi o crescimento do déficit público e da inflação, a deterioração da balança comercial e do balanço de pagamentos, e a explosão da dívida externa. Em outras palavras, a dependência da economia brasileira foi reforçada por outros meios, com o crescimento da participação do capital estrangeiro e o aumento da necessidade de capitais externos para honrar o serviço da dívida e garantir o suprimento de equipamentos e insumos industriais ao recém-instalado parque industrial.

Florestan Fernandes, em apresentação à edição norte-americana do livro de Evans (1980, p. 11), considera que o principal resultado desse período foi que a velha dicotomia centro-periferia tornou-se falsa, na medida em que a nova periferia 
industrializada começou a adquirir um papel relevante dentro do sistema capitalista, com o seu desenvolvimento dependente trabalhando em prol do equilíbrio desse sistema, ao mesmo tempo em que representava a sua revolução a partir da periferia. Isto é, houve uma significativa transformação estrutural na economia-mundo capitalista, em que alguns países do Terceiro Mundo, como o Brasil, deixaram de pertencer à periferia para compor uma nova semiperiferia industrializada, porém ainda subordinada à lógica de acumulação do centro do sistema.

Desse modo, a nova condição da economia brasileira, em um contexto de ampliação e diversificação do Terceiro Mundo, significou novas oportunidades e desafios ao seu desenvolvimento, que a política externa do governo Kubistchek mostrou-se incapaz de aproveitar e lidar. A reafirmação do foco hemisférico pela adoção de uma diplomacia alinhada aos Estados Unidos, tendo a OPA como sua principal iniciativa de política externa, foi pontuada por alguns tímidos movimentos de contestação à perversidade da estrutura internacional para o desenvolvimento da periferia.

Apesar de denunciar as injustiças do comércio internacional nos fóruns multilaterais e defender o desenvolvimento como um requisito para a segurança do continente, este argumento estava em última instância vinculado ao pleito por apoio oficial de Washington ao desenvolvimento do continente. Ou seja, a política externa do governo Kubistchek deu alguns sinais do "novo paradigma das relações exteriores brasileiras" que começara a se formar no segundo governo Vargas, mas não de modo a sinalizar um distanciamento de fato do paradigma americanista. Pelo contrário, reforçou o alinhamento e a relação dependente dos Estados Unidos.

Portanto, tanto os instrumentos da política econômica quanto os da política externa de Kubistchek parecem refletir o entendimento, evidenciado principalmente pelo Plano de Metas no âmbito da economia e pela OPA no das relações exteriores, de que o novo ciclo de industrialização brasileira requeria o apoio dos Estados Unidos e de capitais estrangeiros para o seu sucesso. Isto é, se Vargas buscara negociar o apoio brasileiro aos Estados Unidos sem subordinar o desenvolvimento nacional aos interesses do capital estrangeiro, Kubistchek buscou uma aliança com o capital privado estrangeiro para promover um desenvolvimento associado, configurando um novo tipo de dependência da economia brasileira.

Apesar de ambos os governos terem avançado no movimento de capacitação do Estado condutor do desenvolvimento e de transformação estrutural da economia 
brasileira em direção à diversificação industrial, percebe-se que no governo Vargas houve uma articulação das políticas econômica e externa para o exercício de maior autonomia da economia brasileira e para a redução de sua dependência dos Estados Unidos. Já no governo Kubistchek, o movimento de ambas as políticas foi no sentido de um desenvolvimento subordinado à potência norte-americana, provendo uma política econômica de industrialização associada ao capital estrangeiro e uma diplomacia alinhada aos interesses de Washington.

\subsection{OS GOVERNOS JÂNIO QUADROS E JOÃO GOULART (1956-1961): A AUTONOMIA DA POLÍTICA EXTERNA FRUSTRADA PELAS CONSEQUÊNCIAS DO DESENVOLVIMENTO DEPENDENTE}

\subsubsection{Contextualização}

Entre os anos 1950 e 1960, foi ficando cada vez mais evidente que o alinhamento aos Estados Unidos não estava gerando as contrapartidas esperadas de apoio ao desenvolvimento nacional. Em paralelo, no cenário internacional se multiplicavam as oportunidades de parcerias com as economias europeias e japonesas em ascensão, além do Terceiro Mundo, que se fortalecia. Desse modo, o início dos anos 1960 foi caracterizado pela diversificação do horizonte de alternativas internacionais ao país, em um contexto de intensificação da bipolaridade ideológica da Guerra Fria e do conflito Norte-Sul entre países desenvolvidos e subdesenvolvidos.

No que diz respeito à situação doméstica, foi um período bastante conturbado de crise política e descontentamento social, com o governo Kubistchek tendo deixado uma herança de graves desequilíbrios no balanço de pagamentos e nas contas públicas, além de um processo inflacionário em aceleração e uma dívida externa de quase US\$ 3 bilhões, dos quais 67\% deveriam ser quitados durante o governo de Quadros. Ou seja, o ciclo de desenvolvimento associado promovido no período havia criado e fortalecido importantes elementos de desequilíbrio e dependência econômica, cujas consequências vieram a dificultar a consecução de um programa de desenvolvimento pelo governo posterior. 
Assim, as políticas econômica e externa desse período devem ser entendidas à luz deste contexto, de intensificação da Guerra Fria em paralelo ao fortalecimento da clivagem Norte-Sul; de insatisfação com a falta de comprometimento norte-americano com o desenvolvimento latino-americano; e de profundos desequilíbrios econômicos (fiscal, externo e inflacionário) no país, acompanhados de crescente instabilidade social e política.

\subsubsection{Instrumentos da política econômica}

Tendo herdado de Kubistchek um quadro de sérias restrições externas, com desequilíbrio no balanço de pagamentos e obrigações da dívida cujos prazos de pagamento exigiam soluções imediatas, a equipe econômica de Jânio Quadros optou por

implementar uma reforma cambial nos moldes propostos pelo FMI, suprimindo o sistema de taxas múltiplas para unificar o mercado cambial e desvalorizar o câmbio. Tal reforma foi conduzida por meio das Instruções da Sumoc de números 204 a 208, todas de 1961.

A reforma cambial puniu fortemente os grupos nacionais que haviam contraído financiamento externo nos anos anteriores, tendo levantado pesadas críticas da oposição. Por outro lado, beneficiou os setores exportadores e atendeu aos interesses dos credores internacionais, facilitando a renegociação dos compromissos da dívida que venceriam em seu governo. Nesse sentido, no geral a política econômica de Jânio Quadros é reconhecida pelo esforço de reequilibrar as contas externas e rolar a dívida, alinhando-se para isso aos interesses de seus credores estrangeiros, o que diante dos rumos tomados por sua política externa, gerou a famosa "contradição" entre política econômica e política externa pela qual o seu governo é conhecido (CERVO E BUENO, 2008; TAVARES, 2010, p. 92-93).

Após sua renúncia, o governo João Goulart que o seguiu já contava com uma considerável recomposição das reservas internacionais, beneficiado pela desvalorização cambial e pela renegociação da dívida. No entanto, o novo governo parlamentarista havia se formado sob uma difícil configuração de concessões e compromissos políticos, tendo que enfrentar desconfiados temores de alguns setores sobre as orientações ideológicas do presidente. Assim, visando atenuar receios sobre a política econômica, 
principalmente de alguns grupos políticos e dos credores internacionais, Walter Moreira Salles foi nomeado para a pasta da Fazenda, sinalizando uma política austera e conservadora na economia.

O retorno ao presidencialismo em 1963 trouxe consigo a retomada da programação estatal em prol do desenvolvimento, tendo sido encomendado ao Ministro Celso Furtado, do recém-criado Ministério Extraordinário do Planejamento, a elaboração do chamado Plano Trienal de Desenvolvimento Econômico e Social. Além de programar investimentos visando fortalecer a produção agrícola e os setores de bens de capital e insumos intermediários, o plano previa também medidas de redução das desigualdades sociais e regionais, de redução gradual da inflação, e importantes reformas de base. Dentre estas, destacamos a polêmica reforma agrária e a reforma bancária, que trouxe as propostas de criação do Conselho Monetário Nacional (CMN) e do Banco Central (BCB) visando estruturar o sistema bancário nacional.

As conjunturas internas e externas não eram, porém, favoráveis ao sucesso do plano, que buscava estabilizar a economia brasileira, resolver seus problemas estruturais, realizar reformas polêmicas, e avançar um programa de desenvolvimento nacional. Do lado do setor externo, a intensificação da bipolaridade Leste-Oeste e o paulatino distanciamento da potência norte-americana repercutiam de modo controverso nos grupos políticos e sociais nacionais, intensificando as tensões internas e dificultando o bom andamento das ações governamentais. Assim, grupos de oposição às reformas e políticas propostas começaram a se mobilizar para restringir as margens de manobra do governo para implementar as ações previstas pelo plano, restrições que foram intensificadas pela própria natureza dos problemas econômicos a serem solucionados.

Reflexos das dificuldades desse cenário foram o abandono do Plano Trienal e a alta rotatividade da equipe governamental, tendo o cargo de Ministro da Fazenda sido ocupado por três nomes diferentes somente no ano de 1963. Segundo Tavares (2010, p. 97-101), o plano suscitou fortes oposições de diversos grupos sociais por afetar interesses poderosos, como a proposta de reforma agrária; por necessitar de recursos estrangeiros para financiar seus investimentos e estabilizar o endividamento externo; e por tentar conciliar os "interesses irreconciliáveis" dos defensores das reformas sociais, das elites brasileiras, da estabilização econômica e do programa de desenvolvimento nacional, em um contexto de intensificação da Guerra Fria.

As sucessivas equipes econômicas ainda implementaram as seguintes ações ao longo de 1963: a Missão do Ministro da Fazenda San Tiago Dantas aos Estados Unidos 
visando captar novos recursos para o país; a Instrução da Sumoc $\mathrm{n}^{\circ} 255$, que previa a emissão de letras do governo como meio de se financiar sem gerar pressões inflacionárias; a renegociação salarial de diversas categorias e os reajustes reais do salário mínimo. Em particular, a missão de San Tiago Dantas conseguiu negociar um programa de estabilização da economia em troca do apoio financeiro dos Estados Unidos, com o reescalonamento da dívida com o FMI e novos empréstimos do Eximbank e da Agência para o Desenvolvimento Internacional (AID).

No entanto, em 1964 o governo cancelou as concessões à empresa norteamericana Hanna Mining em Minas Gerais, regulamentando ainda a Lei de Remessa de Lucros no mesmo ano, que limitou remessas para o exterior a $10 \%$ do capital total registrado pelas empresas no país. Além de levantar o alarme dos capitais estrangeiros em oposição ao regime, essas medidas foram acompanhadas pelo acirramento das tensões sociais e políticas, culminando com o golpe militar de 1964, que pôs fím ao governo constitucional e iniciou um período de autoritarismo e repressão.

Evidenciavam-se assim os limites políticos, econômicos e sociais da nova estrutura econômica brasileira, agora dotada de um complexo industrial diversificado e com forte presença do capital estrangeiro, e de sua nova inserção internacional, como nação da semiperiferia da economia-mundo capitalista, mais distante da tradicional subordinação a Washington, porém ainda incapaz de exercer uma autonomia internacional mais completa.

Em suma, os principais instrumentos da política econômica que se relacionaram à inserção internacional da economia brasileira no período foram:

- as Instruções Sumoc no 204, 205, 206, 207 e 208, todas de 1961: reforma cambial que suprimiu o sistema de taxas múltiplas, unificou o mercado cambial e desvalorizou o câmbio;

- a rolagem da dívida externa de 1961;

- o Plano Trienal de Desenvolvimento Econômico e Social de 1962: medidas de estabilização econômica, de investimentos em setores estratégicos, de redução dos desequilíbrios econômicos e sócio-regionais, e reformas de base;

- abandono do Plano Trienal em 1963;

- Missão San Tiago Dantas aos Estados Unidos em 1963: negociação de um programa de estabilização da economia, do reescalonamento da dívida com o FMI e da concessão de empréstimos do Eximbank e da AID; 
- Instrução Sumoc n 255 de 1963: financiamento do governo por emissão de títulos, sem gerar pressões inflacionárias;

- regulamentação da Lei de Remessa de Lucros em 1964: limitação das remessas para o exterior a $10 \%$ do capital total registrado pelas empresas no país.

\subsubsection{Instrumentos da política externa}

A politica externa dos governos Quadros e Goulart foi condicionada, em grande medida, pelas profundas transformações do sistema internacional que vinham ocorrendo desde pelo menos os anos 1950 e pela crescente conscientização de que a continuidade do programa de desenvolvimento econômico nacional requeria uma ampliação e diversificação das parcerias internacionais do país.

Além da insatisfação com a falta de comprometimento de Washington com o desenvolvimento da América Latina, ampliava-se o horizonte internacional de parcerias alternativas aos Estados Unidos com a recuperação europeia e japonesa, a descolonização afro-asiática e o Movimento dos Países Não-Aalinhados, e a consolidação do campo socialista em decorrência do fortalecimento da URSS e a revolução Cubana. No campo das ideias, a CEPAL consolidara-se como fórum de discussão e estudo das especificidades do processo de desenvolvimento dos países latino-americanos, provendo fundamentação teórica e técnica para as políticas da região; enquanto o ISEB confirmara-se na promoção de uma ideologia nacionaldesenvolvimentista, elaborando uma crítica ao foco restrito do americanismo e sua inadequação aos interesses do desenvolvimento nacional (PINHEIRO, 2004, p. 34).

$\mathrm{Ou}$ seja, ambas a bipolaridade Leste-Oeste e a clivagem Norte-Sul se intensificavam, porém enquanto a frustração com a primeira crescia, a segunda evidenciava-se como uma arena cada vez mais atraente para o tratamento dos problemas do desenvolvimento periférico. Todos esses fatores, aliados à nova inserção internacional da economia brasileira que se configurava, como nação da semiperiferia industrializada e subdesenvolvida, contribuíram para a delineação do paradigma globalista, em oposição ao americanista, que conforme Pinheiro (2004, p. 34-35), “contrapunha à tese de que a maior aproximação de Washington elevaria os recursos de 
poder do país, aquela que elegia a diversificação das relações exteriores do Brasil como condição para o aumento do seu poder de barganha do mundo".

Portanto, o quadro que se configurava no governo de Quadros trazia incentivos para o Brasil migrar da diplomacia regional conduzida por Kubistchek para uma "mundial", que diversificasse as parcerias econômicas de modo a aproveitar as oportunidades do sistema internacional sem restrições ou alinhamentos de ordem ideológica ou política. Esta transição foi feita por meio da "Política Externa Independente" (PEI), inicialmente concebida na mensagem presidencial de Quadros de 1961 como um instrumento da política de desenvolvimento, que seria auferido por meio da ampliação das relações internacionais do país sem preconceitos ideológicos. Nas palavras de Amado (1996, p. 284):

Para muitos observadores, a PEI, instituída no governo Quadros, resultou da consciência de que o Brasil já não podia ficar confinado aos princípios do pan-americanismo. Com o fracasso da Operação Pan-Americana (OPA), ficava evidente que a relação especial Brasil-Estados Unidos jamais sairia do papel.

A principal diferença entre a PEI de Quadros e a OPA de Kubistchek foi a ampliação do foco continental para um universal, que colocou os interesses brasileiros acima de ideologias e enfatizou as relações Norte-Sul. Conforme Cervo e Bueno (2008, p. 309-312), Quadros e seu chanceler Afonso Arinos de Melo Franco definiram como princípios da PEI: a autodeterminação e não-intervenção; o direito de cada país planejar o seu desenvolvimento; a mundialização das relações internacionais do Brasil e a atuação isenta de ideologias; a ênfase na oposição Norte-Sul e não na Leste-Oeste; a busca por maior participação nas decisões internacionais; a luta pelo desenvolvimento, pela paz e pelo desarmamento; o repudio às experiências nucleares; e a cooperação latino-americana.

A PEI ainda realinhou a política brasileira na ONU quanto à África Negra:segundo Cervo e Bueno (2008, p. 319-320), o chanceler Afonso Arinos acreditava que o Brasil deveria assumir um papel de destaque no mundo afro-asiático devido as suas características étnicas e culturais, tendo para isso criado um Grupo de Trabalho para a África visando ao estudo de medidas concretas de aproximação econômica e cultural, além de um programa de bolsas para estudantes, uma linha de navegação com o continente africano e novas embaixadas em Gana, Nigéria e Senegal.

Nesse sentido, Rodrigues (1982, p. 306-307) aponta que foi o governo de Quadros que despertou o interesse pelo comércio bilateral com países do continente 
africano. Até então, o autor aponta que as relações com o continente eram turvadas pelo temor da concorrência africana aos produtos de exportação brasileiros. A partir de Quadros, passou a prevalecer "a tese de que a África deve ser apreciada como um novo mercado, sem temor da concorrência de produtos tropicais africanos" (RODRIGUES, 1982, p. 307-308). Assim, o Brasil firmou um acordo para a cooperação conjunta na produção e nas exportações de café com a Organização Interafricana do Café (a Declaração do Rio de Janeiro), acordando ainda um protocolo similar para o cacau.

No entanto, se no campo econômico houve avanços, no político o autor aponta que a política externa de Quadros com relação a África vacilou em inúmeros momentos, como na abstenção durante a votação pela independência de Angola, quando o país oscilou entre Portugal e África. Por outro lado, o autor aponta que, nas demais votações da ONU, a diplomacia de Quadros “iniciou uma política mais definida e decidida em relação a África" (RODRIGUES, 1982, p. 333), com a delegação brasileira pronunciando-se contra o racismo e o apartheid. No entanto, essa política foi interrompida pela renúncia de Quadros, com a diplomacia brasileira retornando a uma ação cautelosa e esporádica de abstenções nas discussões multilaterais sobre a questão africana.

No que diz respeito ao mundo socialista, Quadros promoveu encontros com os líderes de Cuba e da URSS, enviando uma missão especial à URSS para a criação de delegações comerciais permanentes em Moscou e no Rio de Janeiro e propondo o restabelecimento das relações diplomáticas que estavam interrompidas desde 1947. Também restabeleceu relações diplomáticas com países do Leste Europeu (Hungria, Bulgária e Albânia), enviando uma missão econômica especial à região, cujo resultado foi a assinatura de sete acordos comerciais (com a Bulgária, Iugoslávia, Romênia, Hungria, Tchecoslováquia, Polônia e Albânia). Por fim, vale ressaltar a missão especial chefiada pelo vice-presidente João Goulart à República Popular da China, visando a identificar oportunidades de parcerias econômicas e comerciais. (CERVO E BUENO, 2008, p. 318)

$\mathrm{Na}$ América Latina, o governo aproximou-se da Argentina, com a qual firmou instrumentos de cooperação que ficaram conhecidos como os "Acordos de Uruguaiana": um acordo cultural, duas declarações de cooperação econômica e política, e um Convênio de Amizade e Consulta, instituindo um sistema de coordenação da atuação internacional desses países. Por fim, Quadros recusou-se a apoiar os Estados Unidos em seus planos de uma intervenção armada contra o regime de Castro, pedindo a cessação 
das hostilidades na baía dos Porcos à ONU e negando-se a romper com a ilha comunista.

Essas iniciativas da política externa de Quadros contrastam com a orientação majoritariamente conservadora de sua política econômica, levando-nos a aventar que a PEI serviu como um contraponto às ações da política econômica, suavizando algumas de suas proposições e constituindo-se em um meio alternativo de buscar resultados que não se cogitavam possíveis no âmbito da política econômica. Conforme apontam Cervo e Bueno (2008, p. 25), o distanciamento do americanismo promovido pela política externa foi beneficiado pela conjuntura regional, posto que os Estados Unidos receavam que a América Latina escapasse de sua órbita de influência diante dos acontecimentos em Cuba, assim como as medidas de cooperação junto ao Terceiro Mundo foram favorecidas pelo crescente peso e importância que este grupo estava adquirindo no cenário internacional.

Para Amado (1996, p. 285-286), os fundamentos da PEI foram lançados no governo Quadros, para serem consolidados no governo Goulart; de modo alternativo, para Pinheiro (2004, p. 35-36), o período Quadros constituiu a primeira fase da PEI, em que se buscou preservar a paz e aumentar o poder de barganha brasileiro pela possibilidade de manter-se neutro, enquanto a gestão Goulart deu início a uma segunda fase, em que a Guerra Fria foi substituída como questão central das relações exteriores brasileiras pela questão do subdesenvolvimento.

Processou-se um movimento em que a disputa Leste-Oeste foi perdendo seu protagonismo para ser substituída pelo conflito Norte-Sul como eixo condutor da política externa. Com a renúncia de Quadros, o seu embaixador na ONU San Tiago Dantas foi nomeado o novo chanceler do gabinete parlamentarista. Para Cervo e Bueno (2008, p. 328), San Tiago não apenas deu continuidade à PEI de Quadros, mas se tornou um dos seus principais formuladores e atores, ao agir nas arenas internacionais pautado nos interesses do desenvolvimento, da emancipação econômica e da reforma social do país.

Nesse sentido, San Tiago formatou a PEI de Quadros como um instrumento do desenvolvimento nacional entendido de modo vinculado à emancipação da economia brasileira e à sua reforma social. Em suas próprias palavras:

Desenvolver-se é sempre emancipar-se. Emancipar-se externamente, pela extinção de vínculos de dependência a centros de decisão políticos ou econômicos, localizados no exterior. [...] A esse sentido de emancipação dado ao 
desenvolvimento, prendem-se duas características fundamentais da política externa independente: primeiro, o primado dos princípios de não-intervenção e de autodeterminação dos povos, e segundo a opção pelo anticolonialismo. (Dantas, 1964, apud Amado, 1996, p. 287).

As duas principais diferenças com relação à PEI conduzida por Quadros foram: a superação da postura de neutralismo político-ideológico por uma de afirmação de independência, definida por San Tiago como a atuação no sistema internacional em prol de seus interesses e livre de influências estrangeiras; e a ampliação dos mercados de exportação brasileira como prioridade da política externa, visando apoiar a industrialização e reverter a deterioração dos termos de troca. (AMADO, 1996, p. 288)

Desse modo, San Tiago deu continuidade à política de aproximação da Argentina, tendo em vista a sua complementaridade com a economia brasileira, reafirmando as declarações de cooperação econômica e política, e firmando um tratado de extradição e uma convenção de assistência gratuita. Também restabeleceu relações diplomáticas com a URSS, sob o argumento que o bloco soviético oferecia amplas oportunidades econômicas ao Brasil, tendo em vista que a África e a América Latina ainda não dispunham de envergadura suficiente, e a Europa Ocidental estava formando o seu bloco de cooperação econômica (Mercado Comum Europeu).

Porém, apesar de afirmar em suas primeiras declarações os princípios da nãointervenção, autodeterminação e anticolonialismo, Rodrigues (1982, p. 415-416) aponta que San Tiago Dantas não chegou a elaborar uma política para a África: “a política africana, entretanto, que nascera com grandes aspirações, caiu no mais completo silêncio". Segundo o autor, deixou-se apenas de acompanhar a política africana de Portugal e de buscar o conselho de Lisboa (RODRIGUES, 1982, p. 428).

No que diz respeito ao relacionamento com os Estados Unidos, sua deterioração foi marcada em 1962 pela posição brasileira de não intervenção em Cuba diante da proposta de Washington de expulsar o país da OEA, sob a ameaça de suspender os recursos da Aliança para o Progresso dos países não alinhados à sua proposta. Diante da ameaça norte-americana, o Brasil optou por se abster de votar, apesar de declarar-se contra a expulsão, gerando intensa polêmica interna e descontentamento dos Estados Unidos. Por fim, a desapropriação das subsidiárias da empresa norte-americana ITT pelo governador do Rio Grande do Sul, Leonel Brizola, foi o estopim para que Washington suspendesse a ajuda financeira ao país por meio da emenda Hickenlooper, motivando a visita de João Goulart ao país no mesmo ano. 
O resultado dessa visita foi um acordo para a nacionalização pacífica de subsidiárias de empresas estrangeiras e a negociação das indenizações, além de um comunicado conjunto em que o Brasil se comprometia a manter a segurança ao capital privado estrangeiro e dar justa compensação às empresas cujos bens foram nacionalizados. No entanto, conforme Cervo e Bueno (2008, p. 334), tais iniciativas não melhoraram nem o fluxo de capitais privados ao país, nem o proveniente dos órgãos de cooperação multilateral, com o FMI e outras instituições condicionando seu apoio financeiro à adoção de medidas contracionistas de estabilização.

No regime presidencialista, San Tiago foi nomeado para a pasta da Fazenda, sendo sucedido no Itamaraty por três chanceleres: Hermes Lima, Evandro C. Lins e Silva e João Augusto de Araújo Castro. Segundo Cervo e Bueno (2008, p. 349), este último aprofundou os princípios da PEI ao enfatizar a solução de questões universais, que para ele podiam ser sintetizadas em "três Ds" - desarmamento, desenvolvimento e descolonização -, e que deveriam orientar o tratamento das questões específicas internacionais.

Nesse sentido, Araújo Castro destacava o papel da ONU como fórum de discussão e solução dessas questões, alertando que esta não poderia se concentrar apenas no conflito Leste-Oeste, posto que o combate à pobreza e à desigualdade deveria ter prioridade ao combate ao comunismo. Assim, impulsionou uma atuação intensa do Brasil nos trabalhos preparatórios da UNCTAD, organismo da ONU que teria por objetivo discutir as demandas do Terceiro Mundo, chefiando a delegação brasileira na reunião preparatória da I Conferência das Nações Unidas sobre Comércio e Desenvolvimento (I UNCTAD) de 1964. Também participou ativamente na formação do Grupo dos 77, defendendo a reforma do comércio internacional e os interesses do Terceiro Mundo.

Portanto, a PEI foi caracterizada como um processo de aprofundamento e sofisticação dos fundamentos lançados na gestão Jânio Quadros, progressivamente substituindo a disputa Leste-Oeste pela clivagem Norte-Sul como eixo condutor da política externa, e constituindo-se na "primeira manifestação sistemática das teses do globalismo" (PINHEIRO, 2004, p. 36). Como aponta Rodrigues (1966, p. 71), Quadros iniciou a PEI ampliando os limites da diplomacia regional de Kubistchek para o mundo, superando a dependência norte-americana e acrescendo à política externa os objetivos do desenvolvimento, da liberdade de ação internacional e de diversificação das relações 
político-econômicas, aproveitando as mudanças no contexto internacional e a nova posição internacional da economia brasileira, de semiperiferia industrializada.

Embora tenha mantido alguns elementos de incoerência, como no caso da questão da independência africana, da submissão brasileira ao lobby português e da abstenção na expulsão de Cuba da OEA, a PEI buscou distanciar-se do americanismo e do conflito Leste-Oeste, além de consubstanciar-se como um instrumento para o desenvolvimento e a "emancipação" nacional. De certo modo, as "incoerências" apontadas evidenciam os limites de uma atuação verdadeira autônoma do país nas searas internacionais e o descompasso entre suas aspirações de emancipação e a realidade dos seus recursos de poder.

Dividindo por "fases" da Política Externa Independente, seus principais elementos e ações foram:

- a PEI presidencial de Jânio Quadros e Afonso Arinos:

- discurso de defesa da autodeterminação e não-intervenção, da mundialização das relações internacionais, da atuação isenta de ideologias, do desenvolvimento, da paz e do desarmamento;

- manteve o apoio a Portugal: abstenção no voto pela independência de Angola;

- aproximação da África: criação de novas embaixadas, de um Grupo de Trabalho para estudo de medidas de aproximação, de um programa de bolsas para estudantes e de uma linha de navegação com o continente africano;

- aproximação do mundo socialista: encontros com os líderes comunistas, missão econômica especial à URSS e ao Leste Europeu, proposta de restabelecimento das relações diplomáticas com a URSS, restabelecimento de relações diplomáticas com alguns países do Leste Europeu, assinatura de acordos comerciais com Bulgária, Iugoslávia, Romênia, Hungria, Tchecoslováquia, Polônia e Albânia, condenação à intervenção armada em Cuba;

- "Acordos de Uruguaiana" com a Argentina: um acordo cultural, duas declarações de cooperação político-econômica e um Convênio de Amizade e Consulta.

- a PEI de San Tiago Dantas (fim de 1961 a meados de 1962):

- ênfase à PEI como instrumento do desenvolvimento, entendido como elemento relacionado à autonomia externa e à reforma social do país;

- reafirmação da cooperação com a Argentina e assinatura de novos acordos;

- restabelecimento das relações diplomáticas com a URSS; 
- ausência de uma política para a África, apesar do discurso anticolonialista;

- abstenção na OEA pela expulsão de Cuba, apesar de declarar-se contra;

- visita de João Goulart aos Estados Unidos: assinatura de um acordo sobre a nacionalização pacífica de subsidiárias estrangeiras, negociação das indenizações e um comunicado em que o Brasil se comprometia a dar segurança ao capital estrangeiro e justa compensação às empresas nacionalizadas.

- a PEI de Araújo Castro (meados de 1963 a 1964):

- "três Ds": desarmamento, desenvolvimento e descolonização;

- destaque à ONU como fórum de discussão dessas questões, criticando o foco Leste-Oeste e enfatizando o desenvolvimento econômico;

- atuação intensa na criação da UNCTAD e do G77.

\subsubsection{Comparação e resultados}

As diferenças de natureza e alcance entre os instrumentos dos dois canais de atuação da PIIEB nos governos Quadros e Goulart devem sua explicação aos limites e oportunidades colocadas pelos seus respectivos campos de atuação, que determinaram margens de manobra diferenciadas ao exercício da autonomia em prol dos interesses nacionais pela política econômica e pela política externa.

No caso da política econômica, os desequilíbrios herdados do governo Kubistchek limitaram de modo decisivo as possibilidades de atuação do governo Quadros, que girou em torno do problema urgente do pagamento da dívida externa que venceria em sua gestão. Além dos desequilíbrios externo e fiscal dificultarem os meios de financiamento do governo, o acirramento da inflação e das desigualdades socioeconômicas decorrentes do esforço de industrialização anterior significaram a piora das tensões sociais e políticas, evidenciando os problemas da nova condição da economia brasileira como semiperiferia industrializada porém ainda profundamente acometida por desequilíbrios e contradições estruturais.

O cenário desfavorável do governo Quadros intensificou-se no governo de Goulart, cuja política econômica não se limitou à tentativa de estabilização, buscando solucionar os desequilíbrios gerados pelo desenvolvimento associado e programar um 
plano de desenvolvimento nacional. O Plano Trienal foi uma tentativa de conciliar esses problemas por meio de uma equação que combinava estabilização econômica, reformas estruturais, e programa de investimentos visando a instalar a indústria de bens de capital e insumos industriais. Essa combinação, no entanto, revelou-se polemicamente explosiva por envolver interesses conflitantes em um contexto sociopolítico interno já bastante inflamado. Além disso, o plano contava com um apoio financeiro externo que nunca se concretizou.

Já no âmbito da política externa, em contraste, as oportunidades se multiplicavam no cenário internacional, propiciando a formulação da Política Externa Independente pelo governo Quadros, que atuou de certo modo como um contraponto às orientações restritivas e conservadoras de sua política econômica. Afastando-se da subordinação aos Estados Unidos e dos alinhamentos eivados de orientações ideológicas, a PEI foi progressivamente construindo o novo paradigma globalista da diplomacia brasileira, constituindo-se em um importante marco que consagrou a política externa como instrumento do desenvolvimento e adequou-a à nova inserção internacional da economia brasileira como semiperiferia da economia-mundo capitalista.

Assim, da universalização da diplomacia brasileira pelo neutralismo político e ideológico de Quadros, passando pela afirmação da emancipação nacional na luta pelo seu desenvolvimento livre de influências estrangeiras de San Tiago, até os "três Ds" de Araújo Castro, a PEI foi definindo um novo estilo de atuação da política externa brasileira, pautado pelos interesses do desenvolvimento e da autonomia externa, pelos princípios da autodeterminação e não-intervenção, e pela substituição do conflito LesteOeste pelo Norte-Sul. Desse modo, aproximou-se dos países socialistas e latinoamericanos, defendeu ativamente os interesses do Terceiro Mundo nos fóruns multilaterais, contribuiu para a formação da UNCTAD e do Grupo dos 77 e rompeu o alinhamento automático aos Estados Unidos, substituindo o tradicional americanismo da política exterior brasileira pelo novo paradigma do globalismo.

Enquanto os instrumentos de política econômica tiveram seu campo de ação e eficácia tolhido pelos problemas decorrentes do desenvolvimento associado, como os desequilíbrios externo, fiscal e inflacionário; os de política externa encontraram mais espaço no cenário internacional para ampliar a margem de autonomia da economia brasileira na luta pelo seu desenvolvimento, embora também tenham sofrido limitações decorrentes da disparidade entre suas aspirações internacionais e seus recursos de poder. 
Em outras palavras, as ações tanto de política econômica quanto de política externa refletiram as características da nova condição da economia brasileira na posição intermediária de semiperiferia industrializada e subdesenvolvida, em que a dependência tradicional da exportação de primários foi substituída por um novo tipo de dependência, a das tecnologias e capitais estrangeiros, e alguns elementos de subdesenvolvimento, como a heterogeneidade socioeconômica e regional, foram intensificados de modo a exacerbar a instabilidade política e social do país.

Se no governo Kubistchek o aparelho estatal se destacara como condutor do desenvolvimento nacional por meio da aliança ao capital internacional, nos governos Quadros e Goulart esse tipo de papel do Estado encontrou limites nas dificuldades para romper essa forma de dependência externa e solucionar os desequilíbrios estruturais decorrentes da industrialização associada. Por outro lado, a incapacidade do governo Kubistchek de abarcar por meio de sua política externa as oportunidades abertas pelas transformações do cenário internacional e pela nova condição brasileira como semiperiferia industrializada não se repetiu nos governos de Quadros e Goulart, que buscaram, por meio da formulação da política externa independente, instrumentos de ação para contornar os problemas enfrentados na política econômica.

Destarte, em seus governos o Estado conseguiu, por meio da política externa, ampliar seu escopo de atuação, extrapolando os limites da diplomacia continental e utilizando a política externa como um importante instrumento do desenvolvimento, adaptando-a à realidade da nova condição de semiperiferia da economia brasileira, cujos interesses não poderiam ser limitados por condições de ordem político-ideológica. Contudo, mesmo assim a política externa por si só não poderia solucionar os problemas decorrentes do modelo de desenvolvimento associado e colocados pela política econômica, além de o país não apresentar ainda os recursos de poder necessários para alterar de modo mais definitivo o seu tipo de vinculação à economia-mundo capitalista.

\subsection{A CONSTITUIÇÃO DO REGIME MILITAR (1964-1967) ${ }^{81}$ :}

\footnotetext{
${ }^{81}$ Apesar de muitos autores considerarem também o governo Costa e Silva como parte desse período de constituição do regime militar (vide CODATO, 2005, p. 83), sendo seguido pelos períodos de consolidação do regime pelo governo Médici (1969-1974) e transformação pelo governo Geisel (1974 a 1985), optou-se aqui por separar o período Costa e Silva, em decorrência das significativas mudanças de orientação de suas políticas econômica e externa frente às do governo Castelo Branco.
} 


\section{A NEGAÇÃO DA AUTONOMIA PELA INTERDEPENDÊNCIA HEMISFÉRICA}

\subsubsection{Contextualização}

O golpe militar de 1964 contara com o apoio de parte substancial dos grupos políticos e da sociedade civil brasileira, especialmente os setores mais conservadores descontentes com algumas realizações do governo Goulart, como as propostas de reformas estruturais, a lei de remessa de lucros, os reajustes do salário mínimo e as iniciativas da Política Externa Independente. Em especial, os golpistas contaram com a simpatia de Washington, que imediatamente reconheceu o novo regime, fornecendo-lhe apoio político e econômico.

Desse modo, a base de apoio ao novo regime aliou, conforme Visentini (1998, p. 24-25): o capital estrangeiro, o setor agroexportador e a oligarquia agrária tradicional, a moderna classe média urbana e segmentos da elite burocrática civil e militar. As oposições foram sendo expurgadas do cenário por meio da cassação de direitos políticos, exílios e prisões; enquanto o caráter ditatorial do regime ia se fortalecendo por medidas como a extinção dos partidos políticos, a instituição de eleições indiretas, a concessão de poderes ao presidente para cassar direitos políticos, e a promulgação de uma nova Constituição, uma Lei de Imprensa e uma Lei de Segurança Nacional.

Castelo Branco iniciou seu governo tendo como plataformas a eliminação do perigo comunista para restabelecer a ordem e a paz social, e a associação ao capital estrangeiro para retomar o crescimento econômico. Reconhecendo a interpretação bipolar da estrutura de poder mundial, acreditava na aliança do "mundo ocidental" sob a liderança dos Estados Unidos para conter a ameaça comunista e promover o desenvolvimento. Nessa aliança, o Brasil era visto como "membro nato" do Ocidente e aliado especial dos Estados Unidos, esperando assim se beneficiar com o apoio norteamericano à sua aspiração de "Brasil potência".

De certa forma, esta visão teve como uma de suas fontes de inspiração a Doutrina de Segurança Nacional (DSN) desenvolvida pelo Conselho de Segurança Nacional dos Estados Unidos como parte de sua estratégia de contra insurreição ao avanço do comunismo na América Latina. Visando principalmente assegurar a liderança 
ameaçada de Washington no continente, a DSN imbuiu-se de argumentos ideológicos típicos da Guerra Fria, centralizados na ideia da segurança coletiva regional para defender os valores democráticos do mundo ocidental contra os perigos do comunismo. Nesse sentido, a América Latina era vista como um subsistema regional do mundo ocidental, cujo controle seria garantido pela subordinação de seus países a sublideranças regionais aliadas aos Estados Unidos. Em contrapartida, essas sublideranças esperavam o apoio de Washington para exercer poder na região e promover o seu desenvolvimento, por meio da transferência de recursos financeiros, investimentos e tecnologias, além da abertura do mercado norte-americano para suas exportações. (VISENTINI, 1998, p. 35)

Essas formulações da DSN encontraram terreno fértil em um grupo da Escola Superior de Guerra (ESG), portador de um discurso crítico em relação ao nacionalismo e simpático ao capital internacional, em oposição a um segundo grupo que via com bons olhos um programa de desenvolvimento conduzido por um Estado forte e de modo mais autônomo do capital estrangeiro. Apesar desse debate sobre qual deveria ser a natureza do projeto de desenvolvimento nacional, na passagem para os anos 1960 parece ter prevalecido a visão do desenvolvimento como a construção de uma sociedade industrial de destaque no "mundo livre capitalista", ou seja, a ideia do "Brasil potência" aliado do centro hegemônico no mundo ocidental. (OLIVEIRA, 2010, p. 143)

Em paralelo, as elites civis e os grupos associados ao capital internacional que se viam ameaçados pelo fortalecimento dos movimentos de trabalhadores e das esquerdas, especialmente após os rumos tomados pelo governo Goulart, encontraram nas Forças Armadas meios de assegurar seus interesses, formando uma aliança em prol da "segurança nacional". Assim, foi formulada a versão brasileira da DSN, tendo como fronteira ideológica a bipolaridade da Guerra Fria e como fundamento o conceito de interdependência americana em prol da segurança e do desenvolvimento coletivo. Nessa visão, as Forças Armadas teriam um papel "tutelar" da sociedade, devendo garantir os "interesses nacionais" por meio do binômio "segurança e desenvolvimento".

No entanto, tais formulações contrastavam com a situação internacional, que evoluía em direção contrária ao recrudescimento da Guerra Fria desde pelo menos 1962: além de ambos os blocos não conseguirem conter o surgimento de fissuras internas, Estados Unidos e URSS promoviam entre si ações de aproximação tanto no campo militar quanto no econômico. No que tange aos movimentos de desagregação interna aos blocos, do lado ocidental o enfraquecimento foi preconizado pela França do presidente De Gaulle, que se opôs à doutrina do "Grande Destino" do presidente 
Kennedy (a união da Europa Ocidental sob a liderança dos Estados Unidos para lutar contra o comunismo); enquanto do lado oriental, as tensões internas cresciam, como sinalizado pelo rompimento da China comunista com a URSS em 1964 e a emancipação da Romênia no ano seguinte. (Cervo e Bueno, 2008, p. 369-371)

Em paralelo, Estados Unidos e URSS promoviam diálogos visando acordar o desarmamento parcial e controlar os seus arsenais nucleares, além de incrementarem o comércio bilateral entre si. Neste contexto, a reafirmação pelo Brasil das fronteiras ideológicas da Guerra Fria não correspondia à realidade internacional que se configurava, mas sim aos interesses norte-americanos de manter a América Latina sob sua zona de controle e influência, contribuindo mais para reforçar a subordinação brasileira ao poderio de Washington do que para atender sua aspiração de "Brasil potência".

Essa concepção ilusória da orientação política brasileira frente à realidade do panorama internacional mostrou-se ainda mais fantasiosa diante do fortalecimento da clivagem Norte-Sul e da denúncia das injustiças infligidas pelo Primeiro Mundo aos povos em desenvolvimento. Com os avanços da descolonização da África, o Terceiro Mundo surgia com força no cenário internacional, abarcando 122 nações unidas pela consciência das desigualdades da estrutura político-econômica mundial, deslocando "o eixo gravitacional do sistema internacional, no que dizia respeito aos interesses dos povos em vias de desenvolvimento, de Leste-Oeste para Norte-Sul" (CERVO E BUENO, 2008, p. 372). Evidenciava-se, assim, que o Brasil de Castelo "remava contra a corrente" ao trocar o paradigma da emancipação econômica por uma postura de subordinação irrestrita aos Estados Unidos.

\subsubsection{Instrumentos da política econômica}

A Doutrina de Segurança Nacional previa que cada país do sistema interamericano deveria assumir mais funções em prol da segurança coletiva hemisférica e da solidariedade econômica continental. Em troca, Washington ofereceria ajuda econômica e técnica para o desenvolvimento desses países, no formato do modelo de 
desenvolvimento dependente e associado. O Brasil, junto à Argentina e ao México, seriam, conforme Martins (1975, p. 59-60), os “aliados preferenciais" dos Estados Unidos no continente, devendo manter o controle da região em troca da promessa de receberem significativos fluxos de investimentos e empréstimos norte-americanos.

Nesse sentido, uma das primeiras medidas da equipe econômica foi a revogação da Lei de Remessa de Lucros de João Goulart pela Lei no 4390 de 1964, tendo ainda acordado com os Estados Unidos o pagamento de indenizações às empresas cujos bens foram nacionalizados no governo anterior. No ano seguinte, o governo promulgou ainda um acordo de garantia aos investimentos dos Estados Unidos, confirmando sua prerrogativa de manter um ambiente favorável ao capital estrangeiro privado.

Esse conjunto de medidas foi bem recebido pelos norte-americanos. Conforme Visentini (1998, p. 25-26), Washington logo liberou para o novo regime militar os recursos da Agência para o Desenvolvimento Internacional (USAID) e do Banco Interamericano de Desenvolvimento (BID) que estavam bloqueados durante o governo Goulart, e o FMI e o Banco Mundial voltaram a conceder empréstimos para o Brasil, embora em volumes modestos. Além disso, a equipe econômica conseguiu ainda escalonar a dívida brasileira com os Estados Unidos, a Europa e o Japão.

Por outro lado, as contradições do desenvolvimento associado haviam piorado nos governos de Quadros e Goulart, colocando como grande desafio do novo regime conciliar a correção dos desequilíbrios estruturais da economia e a retomada do crescimento econômico. Assim, o ministro da Fazenda Octavio Gouveia de Bulhões, junto ao ministro do Planejamento Roberto Campos, lançou em 1964 o Programa de Ação Econômica do Governo (Paeg), prevendo um pacote de medidas restritivas para conter a inflação e o déficit público, como o aumento da taxa de juros e dos impostos, e a contenção dos salários, das despesas públicas, do crédito e dos subsídios.

$\mathrm{Na}$ realidade, ao contrário da visão comum que encara o Paeg como um mero plano de estabilização econômica, Tavares (2010, p. 112) aponta que o plano também envolveu reformas estruturais e uma programação de investimentos em setores específicos, como a agricultura, a indústria, a infraestrutura e a mineração.

No que tange às reformas previstas pelo plano, destacaram-se a reforma tributária, que aumentou a eficiência e o montante da arrecadação pública, e a do sistema financeiro nacional, que ergueu uma estrutura de financiamento mais favorável ao fortalecimento da acumulação de capital nacional. Nesse sentido, além de estruturar um sistema de controle da política monetária e do sistema bancário por meio da criação 
do Banco Central e do Conselho Monetário Nacional em substituição à Sumoc (Lei $\mathrm{n}^{\mathrm{o}}$ 4595 de 1964), procurou-se ativar a bolsa de valores, criou-se os bancos de investimento e introduziu-se ainda o mecanismo da correção monetária, que permitiu a manutenção do valor real de contratos e investimentos, estimulando a poupança nacional e os investimentos de longo prazo.

Ressalte-se ainda a estruturação, por meio da Lei $n^{0} 4380$ de 1964, de um sistema de financiamento da habitação, com a criação do Banco Nacional de Habitação $(\mathrm{BNH})$, das Sociedades de Crédito Imobiliário, das Letras Imobiliárias e do Serviço Federal de Habitação e Urbanismo. Por fim, a Lei nº 107 de 1966 criou o Fundo de Garantia por Tempo de Serviço (FGTS), cujos recursos seriam usados para financiar o BNH e também indenizar os casos de desemprego, aposentadoria, invalidez ou morte do trabalhador. Para Tavares (2010, p. 114), o FGTS legitimou a flexibilização do mercado de trabalho, tendo em vista que os trabalhadores não podiam mais contar com a estabilidade no emprego.

$\mathrm{Na}$ visão da mesma autora, essas reformas foram essenciais para adequar a estrutura de financiamento nacional à nova complexidade econômica decorrente do processo de industrialização e urbanização já realizado. Além de melhorarem as condições de financiamento público e privado, estimularam ainda o setor da construção civil, favorecendo a retomada dos investimentos e do crescimento econômico, propiciando a formação de um novo ciclo de acumulação de capital, que beneficiou os governos posteriores dos anos do "milagre econômico". (Tavares, 2010, p. 117-118)

A necessidade de ampliar os mercados externos e diversificar as exportações brasileiras foi reconhecida pelo governo Castelo por meio de medidas de desvalorização cambial, de simplificação e desoneração dos processos burocráticos de exportação, e de financiamento das exportações pela Câmara de Comércio Exterior (Cacex). Assim, em 1964, a Sumoc instituiu duas Instruções: a de $n^{\circ} 278$, de reforma do sistema de financiamento às exportações de manufaturados, e a $\mathrm{n}^{\mathrm{o}} 279$, de permissão aos exportadores para usar parte das divisas auferidas com suas exportações para a importação de máquinas e insumos industriais. No mesmo ano, foram promulgados o Decreto $n^{\circ} 53982$, que vinculou as importações de petróleo a uma recíproca exportação de manufaturas; e a Lei $\mathrm{n}^{\mathrm{o}} 4502$, que isentou de impostos de consumo os produtos industrializados destinados à exportação. Em 1965, a Lei no 4663 reduziu o imposto de renda dos exportadores de manufaturados, e a Lei $n^{\circ} 4678$ introduziu o seguro de crédito à exportação. (Bado, 2006, p. 62) 
Além dos incentivos às exportações, o equilíbrio do balanço de pagamentos envolveu também o controle das importações, por meio da aplicação da Lei do Similar Nacional, que considerava "nacional" o produto fabricado no país, fosse por empresa brasileira ou estrangeira. Em 1966, o presidente instituiu ainda o Decreto-Lei no 63, que estabeleceu a tarifa aduaneira como instrumento "selecionador" de importações: enquanto as tarifas de alguns produtos foram elevadas visando proteger alguns setores e/ou estimular a formação de novos setores no país, outras foram reduzidas com o objetivo de baratear a importação de bens sem produção nacional.

Ou seja, os instrumentos da política econômica de inserção internacional do governo Castelo agiram em prol de um modelo de desenvolvimento associado ao capital estrangeiro que, se por um lado propiciou condições para um ciclo posterior de crescimento e para uma nova inserção internacional da economia brasileira como exportadora de manufaturados, por outro lado aprofundou certos aspectos da sua dependência externa sob novas formas de subordinação, especialmente ao capital estrangeiro como fornecedor das tecnologias, equipamentos e insumos necessários à produção industrial brasileira.

Portanto, como nota Singer (1989, p. 115), a estratégia de industrialização deixou de concentrar-se somente nas necessidades do mercado interno para começar a voltar-se novamente "para fora", dessa vez visando exportar manufaturados para o mercado mundial, em um novo padrão de inserção internacional da economia brasileira. Entretanto, o mesmo autor avalia que essa mudança de padrão acabou implicando no aprofundamento da dependência externa brasileira, na medida em que se ampliaram os setores dependentes de exportações para manterem-se dinâmicos (primários e manufaturados leves) e os setores dependentes de importações de máquinas e equipamentos para manter seus processos industriais.

Em suma, destacaram-se como instrumentos da política econômica de inserção internacional da economia brasileira do governo Castelo:

- o Programa de Ação Econômica (Paeg):

- medidas restritivas de estabilização (aumento da taxa de juros e de impostos, contenção salarial e creditícia, corte das despesas e subsídios públicos);

- Lei no 4390 de 1964: revogação da Lei de Remessa de Lucros de 1964;

- pagamento de indenizações às empresas estrangeiras nacionalizadas;

- Decreto $\mathrm{n}^{\circ} 57943$ de 1966: Acordo de garantia de investimentos dos EUA;

- reescalonamento da dívida externa brasileira com os EUA, Europa e Japão; 
- reforma tributária;

- reforma bancária: Leis no 4357 e 4595 de 1964 de criação do BCB e do CMN;

- criação do mecanismo da correção monetária, medidas de estímulo à bolsa de valores e criação dos bancos de investimento;

- Lei no 4380 de 1964: criação do Banco Nacional de Habitação (BNH), das Sociedades de Crédito Imobiliário, das Letras Imobiliárias e do Serviço Federal de Habitação e Urbanismo;

- Lei no 107 de 1966: criação do FGTS;

- desvalorização das taxas de câmbio visando estimular as exportações;

- Instrução Sumoc n 278 de 1964 (reforma do sistema de financiamento às exportações de manufaturados);

- Instrução Sumoc no 279 de 1964 (permissão para o uso das divisas de receitas de exportação na importação de máquinas e insumos industriais);

- Decreto no 53982 de 1964 (vinculação das importações de petróleo a uma recíproca de exportações de manufaturados);

- Lei no 4502 de 1964 (isenção do imposto de consumo aos bens industriais destinados à exportação);

- Lei no 4663 de 1965 (redução do imposto de renda aos exportadores de manufaturados);

- Lei no 4678 de 1965 (criação do seguro de crédito à exportação);

- Decreto-Lei no 63 de 1966 (reforma aduaneira, elevando algumas tarifas e reduzindo outras, para proteger a produção nacional e baratear a importação de bens não produzidos no país).

\subsubsection{Instrumentos da política externa}

A política externa do governo Castelo, assim como a econômica, girou em torno da Doutrina de Segurança Nacional (DSN), retomando como orientação o alinhamento aos Estados Unidos e as fronteiras ideológicas da bipolaridade Leste-Oeste. Na realidade, as implicações da DSN foram mais além do que o simples retorno ao 
americanismo. Situando o Brasil como membro do Ocidente capitalista sob a liderança norte-americana, a diplomacia nacional substituiu o desenvolvimento como objetivo prioritário pelo binômio "segurança e desenvolvimento", ou seja, a segurança contra o comunismo como objetivo relacionado ao "desenvolvimento econômico", cujo próprio conteúdo passou por grande resignificação pelo novo governo.

Para Martins (1975, p. 61-63), a DSN significou o reconhecimento da existência de uma "força internacional", representada pela solidariedade entre Estados, que se sobrepunha às "soberanias nacionais", substituindo os interesses nacionais pelos interesses gerais do coletivo. Portanto, a política externa de Castelo pressupôs a renúncia da soberania nacional brasileira, em troca de um papel de destaque na manutenção desse sistema interamericano e do status de "aliado preferencial" de Washington na região. O Brasil assumiu assim o papel de "sublíder" regional, agindo localmente de modo a garantir os interesses da potência hegemônica em troca de um tratamento diferenciado. Segundo Visentini (1998, p. 39-40), esperava-se dos Estados Unidos, além do apoio à subliderança regional, também ajuda técnica e financeira, a abertura do mercado norte-americano para as exportações brasileiras e uma estrutura de preços compensadora no comércio bilateral.

Tal guinada de rumos em relação à Política Externa Independente do governo anterior envolveu uma profunda "adequação" do corpo diplomático brasileiro, com inúmeros afastamentos, demissões e aposentadorias no Itamaraty. O novo MRE retomou uma diplomacia hemisférica, centrada no alinhamento ao "líder do mundo ocidental" na luta contra o comunismo, e que deveria servir de instrumento para a construção de "um Poder Nacional que faça do Brasil uma potência ouvida no concerto dos fortes e respeitada naquele dos fracos" (VISENTINI, 1998, p. 29).

Desse modo, o Brasil defendeu junto a Washington a constituição de uma Força Interamericana de Paz no âmbito da OEA, proposta não endossada pela maioria dos países latino-americanos por oficializar um instrumento de intervenção anticomunista em suas soberanias. Também rompeu relações com Cuba em 1964, votando por isolar a ilha do continente na IX Reunião de Consulta dos Ministros das Relações Exteriores da OEA e favorecendo a imposição de sanções econômicas e diplomáticas. No mesmo ano, afastou-se da República Popular da China, e em 1965, participou da intervenção militar de Washington na República Dominicana, obtendo o comando das forças interamericanas de paz ali instaladas até a formação de um governo provisório. 
A política externa brasileira orientou-se pela ideia de "círculos concêntricos", que dizia respeito à existência de uma hierarquia de regiões prioritárias para o país: primeiramente, a região do "Rio da Prata", seguida da América do Sul, e só então, do Hemisfério Ocidental. Nesse sentido, a América Latina seria o "mercado natural de comércio" do Brasil, devendo os Estados Unidos apoiar as aspirações brasileiras na região. É importante ressaltar que, como nota Visentini (1998, p. 48-49), o foco estava no pan-americanismo, e não no latino-americanismo. Nesse sentido, tanto no âmbito político quanto no econômico, o país se posicionou contra à possibilidade de uma unidade latino-americana, defendendo a integração somente na medida em que envolvesse também os Estados Unidos. A integração político-econômica da América Latina deveria ocorrer sob a égide da OEA e da Aliança para o Progresso.

De qualquer modo, os esforços de aproximação com os demais países do continente foram intensificados, com o chanceler Juracy Magalhães visitando o Chile, Bolívia, Argentina, Uruguai, Equador e Peru em 1966. No ano seguinte, o país assinou ainda uma resolução de compromisso com o desenvolvimento de programas multilaterais e bilaterais na região, envolvendo a Argentina, Bolívia, Paraguai e Uruguai.

As principais iniciativas bilaterais na região foram com a Argentina. Além de se comprometerem conjuntamente a fortalecer a ALALC e os mecanismos de segurança coletiva da OEA, assinaram um acordo comercial em 1964 (“Acordo do Trigo") e formaram uma Comissão Especial para a cooperação política e econômica em 1965. Também se destacaram os acordos com o Paraguai para a criação da Ponte da Amizade em 1965 e para o desenvolvimento de projetos energéticos nas Sete Quedas (Ata das Cataratas de 1966), com a constituição da Comissão Técnica Mista BrasileiroParaguaia.

Apesar do pró-americanismo, logo começaram a aparecer divergências com a potência, principalmente no campo econômico. Conforme Visentini (1998, p. 45-46), já em 1966 a diplomacia brasileira aludia à falta de tratamento diferenciado para as exportações brasileiras em troca do alinhamento. De sua parte, o governo norteamericano enfrentava questionamentos do congresso sobre a assistência concedida aos regimes militares da América Latina, em especial Brasil e Argentina, o que levou o presidente Jonhson a condenar as ditaduras latino-americanas em 1966. 
A insatisfação brasileira com a falta de retorno econômico por parte dos Estados Unidos encontrou vazão em alguns fóruns multilaterais de cunho econômico ${ }^{82}$, como a UNCTAD e o GATT, onde o chanceler Juracy Magalhães insistiu na tese de que a solidariedade econômica era o outro lado da segurança coletiva, sendo que um dependia do outro. Assim, apesar de moderada pelo discurso ideológico do regime militar e adotando uma postura independente do Terceiro Mundo, houve uma atuação brasileira nos fóruns multilaterais em defesa do desenvolvimento dos povos atrasados e reivindicando o envolvimento do Primeiro Mundo na correção dos desequilíbrios comerciais. Conforme Cervo e Bueno (2008, p. 377-378), o Brasil atribuiu aos países desenvolvidos a responsabilidade pelo desenvolvimento do Terceiro Mundo, negandose a firmar o Acordo para o Comércio de Têxteis que prejudicava as exportações desses países para a Europa e Estados Unidos, defendendo o desarmamento e o uso dos recursos assim economizados em um fundo de desenvolvimento.

A política externa brasileira teve ainda ativa participação na promoção das exportações brasileiras, atuando em conjunto com o Ministério da Fazenda para aumentar e diversificar os mercados de exportação do país. Assim, aproximou-se economicamente dos países socialistas da Europa Oriental, tendo em vista a identificação de um considerável potencial comercial com a região, a despeito das divergências político-ideológicas. Conforme Visentini (1998, p. 63), os Estados Unidos não se posicionaram contra tal aproximação, por se tratar de uma aproximação de fins puramente comerciais, dando abertura para o incremento das relações econômicas com o bloco soviético.

Nesse sentido, a aproximação envolveu a formação de delegações comerciais e comissões mistas, trocas de visitas oficiais e de cooperação, assinatura de acordos comerciais com a URSS, Bulgária, Hungria e Polônia (no geral para exportação de primários e importação de maquinas e equipamentos) e um acordo de fornecimento de ajuda técnica russa para a construção de uma petroquímica no Brasil.

Também buscou a aproximação da África, tendo em vista estudos realizados pelo MRE identificando oportunidades para a economia brasileira nos mercados africanos, tanto em termos de produtos brasileiros exportáveis quanto de bens africanos importáveis. No entanto, a política externa com relação à África continuou mostrando-

\footnotetext{
${ }^{82}$ No geral, o Brasil apoiou as posições norte-americanas na ONU e na OEA.
} 
se ambígua, reafirmando os "laços de amizade" com Portugal e apoiando os países colonialistas.

Assim, o Brasil apoiou Portugal nas discussões da ONU, mas também promoveu iniciativas de aproximação do continente africano, principalmente no âmbito econômico. Foram exemplos dessa aproximação a visita do presidente do Senegal com assinatura de acordos para constituição de comissões mistas e o estreitamento das relações econômicas e culturais entre os dois países, além da realização de duas Missões Comerciais à África Ocidental (Senegal, Libéria, Gana, Nigéria, Camarões e Costa do Marfim; e África do Sul, Moçambique Angola, Gana e Costa do Marfim).

Portanto, a política exterior do governo Castelo Branco foi caracterizada pela retomada do americanismo e das restrições ideológicas da Guerra Fria, centrando-se em um projeto de "Brasil potência" com destacada atuação no cenário internacional. Nesse sentido, priorizou as relações interamericanas sob a liderança dos Estados Unidos, desenvolvendo uma ativa diplomacia local de protagonismo na região. Por outro lado, as necessidades do modelo de desenvolvimento associado requeriam, além da participação do capital estrangeiro, a conquista de mercados para ampliar e diversificar as exportações brasileiras. Na medida em que se restringia ao campo econômico, não implicando em concordância político-ideológica, a política externa de Castelo aproximou-se do bloco soviético e do continente africano, visando estritamente ampliar o intercâmbio comercial brasileiro e diversificar suas parcerias econômicas.

Em suma, as principais ações e instrumentos da política externa de inserção internacional da economia brasileira foram:

- o protagonismo regional (aliado preferencial dos Estados Unidos na região);

- o rompimento com Cuba e apoio ao isolamento da ilha em 1964;

- o afastamento da República Popular da China em 1964;

- a participação na intervenção militar dos EUA na República Dominicana em 1965, comandando as forças interamericanas de paz;

- a assinatura com Argentina, Bolívia, Paraguai e Uruguai de um compromisso para o desenvolvimento de programas multinacionais e bilaterais na região em 1967;

- a assinatura com a Argentina de acordos comerciais e de cooperação;

- a assinatura com o Paraguai de um acordo para a criação da Ponte da Amizade em 1965, e da Ata das Cataratas em 1966 (desenvolvimento de projetos energéticos nas Sete Quedas e constituição da Comissão Técnica Mista Brasileiro-Paraguaia); 
- a atuação na UNCTAD e no GATT: defesa do desenvolvimento do Terceiro Mundo, atribuição aos países desenvolvidos a responsabilidade pelo desenvolvimento, recusa ao Acordo para o Comércio de Têxteis, defesa do desarmamento e da constituição de um fundo de desenvolvimento com os recursos do desarmamento;

- a aproximação econômica do bloco soviético, com visita do Ministro do Planejamento Roberto Campos à URSS para importação de máquinas e tecnologias; assinatura de protocolos comerciais com a URSS, Bulgária, Hungria e Polônia para compra de máquinas e equipamentos e venda de café, ferro e outros insumos; e de um acordo de ajuda técnica russa para a construção de uma petroquímica no Brasil;

- a aproximação econômica da África, apesar do apoio à Portugal, com assinatura de acordos com o Senegal e duas Missões Comerciais à África Ocidental (Senegal, Libéria, Gana, Nigéria, Camarões e Costa do Marfim; e África do Sul, Moçambique Angola, Gana e Costa do Marfim).

\subsubsection{Comparação e resultados}

Os instrumentos de política econômica e de política externa de inserção internacional da economia brasileira do período refletiram a acentuada correção de rumos realizada pelo regime militar em relação ao governo anterior. Resgatando as fronteiras ideológicas da Guerra Fria e do combate ao comunismo, tanto a política econômica quanto a política externa recuaram no pleito por maior autonomia do país nas arenas internacionais em prol de seus interesses, substituindo-a pela afirmação da interdependência pan-americana sob a liderança dos Estados Unidos em prol da segurança coletiva e cooperação econômica.

$\mathrm{Na}$ realidade, tais movimentos foram inspirados pela ideia, aspirada por parte das elites civis e militares, do Brasil como uma nação industrializada e de reconhecido papel de destaque no mundo capitalista ocidental. Dessa vez, em troca de seu alinhamento aos Estados Unidos, o Brasil buscava não apenas apoio técnico-financeiro para o seu desenvolvimento, mas também apoio político-militar para exercer um papel de protagonismo no sistema interamericano, como potência média aliada ao centro hegemônico. 
A Doutrina de Segurança Nacional e seus conceitos derivados de segurança coletiva e solidariedade hemisférica foram o arcabouço ideológico veiculado para inspirar e justificar as ações empreendidas em prol dessa aspiração por maior protagonismo. Destarte, a subordinação aos Estados Unidos foi retomada em troca de promessas de apoio político e econômico, intensificando o modelo de desenvolvimento associado e dependente do capital estrangeiro e voltando a posicionar o país sob a influência norte-americana.

Do lado da política econômica, isto se expressou pela adoção de políticas de favorecimento ao capital estrangeiro, de medidas restritivas visando estabilizar a economia, e de reformas estruturais visando a criar um ambiente favorável aos investimentos privados, como a flexibilização do mercado de trabalho e a reforma do sistema financeiro nacional. Apesar da piora das desigualdades sociais decorrente da compressão salarial das massas trabalhadoras, a concentração de renda favoreceu a nova classe média e as elites, cujo consumo de bens duráveis, incentivado ainda pelas medidas de crédito ao consumo realizadas pelo governo, estimulou a dinamização desses setores industriais, com efeitos multiplicadores pela economia.

Além disso, o papel do Estado como condutor estratégico do desenvolvimento nacional não foi abandonado, com a programação de investimentos e incentivos a setores específicos feita pelo Paeg e a ativa política de estímulo às exportações visando equilibrar o balanço de pagamentos e atender à importação de máquinas e insumos necessários à continuação do processo de industrialização. Desse modo, os instrumentos da política econômica buscaram expandir e diversificar a pauta de produtos exportados por meio de incentivos fiscais, creditícios e cambiais.

De modo quase análogo, a política externa buscou afirmar o papel brasileiro como aliado "preferencial" dos Estados Unidos e ator privilegiado no sistema interamericano, apoiando os interesses norte-americanos e defendendo as teses de segurança coletiva e solidariedade econômica continental. Assim, o país afastou-se de Cuba e da República Popular da China, além de defender junto aos Estados Unidos a proposta, criticada pela maioria dos países latino-americanos, de criação de uma Força Interamericana de Paz.

No geral, os instrumentos de política externa refletiram o binômio "segurança e desenvolvimento", um vinculado ao outro e não sendo possível sem o outro. Nesse sentido, as prioridades políticas e econômicas do país foram ordenadas conforme círculos concêntricos a partir de seus domínios territoriais. Assim se explica o foco da 
diplomacia brasileira na cooperação econômica no âmbito pan-americano, e da aproximação com os Estados Unidos e a América Latina, seus vizinhos e principais mercados de exportação.

No entanto, na medida em que o apoio esperado dos Estados Unidos não se concretizou de modo satisfatório, e as necessidades do processo industrial brasileiro exigiam crescentes importações de máquinas e equipamentos, a diplomacia brasileira retomou, ao lado da política econômica, as tentativas de expandir as exportações nacionais. Assim, apesar das fronteiras político-ideológicas e de se posicionar junto ao Primeiro Mundo capitalista e ocidental, a política externa não se eximiu de estreitar os laços econômicos com o bloco soviético e com o continente africano, de reconhecido potencial como mercados consumidores de exportações brasileiras e fornecedores de máquinas e equipamentos no caso da URSS, e de insumos e matérias-primas no caso da África.

Portanto, tanto a política econômica quanto a política externa do regime de Castelo Branco trabalharam em prol de uma inserção internacional do país como uma economia industrializada e pertencente ao mundo ocidental, que aspirava a um maior protagonismo como potência média de destaque. Para isso, posicionou-se de modo subordinado à liderança dos Estados Unidos, recuando no seu pleito por maior autonomia a partir de uma visão interdependente do sistema ocidental, em que tanto a segurança quanto o desenvolvimento nacional foram subordinados ao discurso da segurança coletiva e da solidariedade econômica.

\subsection{RECRUDESCIMENTO E TRANSFORMAÇÃO DO REGIME} MILITAR (1967-1979): A AUTONOMIA PELA REDEFINIÇÃO DA 


\section{DEPENDÊNCIA EM MEIO À CRISE DO CICLO SISTÊMICO DE ACUMULAÇÃO NORTE-AMERICANO}

\subsubsection{Contextualização}

Ao final dos anos 1960, as transformações da economia-mundo capitalista apontavam para um mundo cada vez mais multipolar, em que a bipolaridade que dividira a ordem mundial entre Estados Unidos e URSS estava sendo substituída por uma ampliação e diversificação dos polos de poder. Para além da plena recuperação da Europa Ocidental e do Japão, e do fortalecimento do Terceiro Mundo com a descolonização afro-asiática, ganhavam destaque como atores importantes no cenário mundial a OPEP e a China, exemplos de países que conseguiram exercer mais influência nas questões internacionais.

Internamente, o Estado brasileiro havia construído desde o fim da Segunda Guerra uma maior capacidade técnica e institucional para gerenciar e programar o processo de desenvolvimento nacional. Essa combinação entre maior capacidade do poder público brasileiro e maior flexibilidade do cenário internacional teria permitido ao país, na interpretação de Lima e Moura (1982, p. 350), exercer maior autonomia em prol de seus interesses nas questões externas. No entanto, apontam esses autores, tal mudança implicava em um gradual distanciamento da tradicional subordinação aos Estados Unidos, podendo levar até mesmo a um rompimento e emancipação, em um processo que fatalmente envolveria tensões e conflitos com a potência norte-americana.

Além disso, o exercício da autonomia foi também obstado pelas consequências do modelo de desenvolvimento associado, estruturado durante a gestão Kubistchek, cujas linhas gerais foram aprofundadas durante o milagre econômico. Se por um lado gestaram-se as condições para estruturar o capitalismo nacional, realizando-se nos anos 1950 o primeiro grande ciclo endógeno de crescimento impulsionado pelo Estado, por outro lado aguçaram-se seus desequilíbrios internos e externos pela intensificação de alguns elementos de fragilidade externa, como a crescente dependência dos capitais financeiros e produtivos estrangeiros. Em consequência, as tentativas de Quadros e Goulart para conduzir os interesses brasileiros de modo mais autônomo e independente de alinhamentos foram dificultadas não apenas pelas críticas e pressões de Washington, 
mas também pelos obstáculos estruturais decorrentes das contradições do modelo de desenvolvimento dependente e associado.

$\mathrm{O}$ imediato retorno ao americanismo produzido pelo primeiro governo militar reafirmou a submissão brasileira aos Estados Unidos e ao capital estrangeiro, e substituiu a soberania nacional pela ideia da interdependência solidária pan-americana, por meio de um "pacto subimperialista imaginado" (MARTINS, 1975, p. 66).

Por outro lado, o governo Castelo empreendeu importantes reformas estruturais que foram cruciais para a transformação posterior da economia brasileira, propiciando condições para o Estado empreender um novo ciclo endógeno de acumulação nos anos do "milagre econômico brasileiro". Conforme Tavares (2010, p. 116-117), o ciclo de crescimento e industrialização realizado por Vargas e Kubitschek criara um complexo econômico de grande dinamismo, para o qual as estruturas e instrumentos disponíveis para o seu controle e gerenciamento eram insuficientes e inadequadas. Era necessário um arcabouço institucional e instrumental mais sofisticado, que foi estruturado por meio das reformas implementadas entre 1964 e 1967.

De certo modo, os três governos militares posteriores a Castelo revisaram, em escalas diferentes, essas orientações político-ideológicas, cada qual readequando à sua maneira a postura brasileira e o modo de condução do seu processo de desenvolvimento às novas realidades do panorama internacional e dos desafios decorrentes do modelo de desenvolvimento associado. Apesar de suas diferenças, esses governos promoveram de modo paulatino, principalmente na gestão Geisel, a programação de investimentos visando eliminar progressivamente a dependência das importações de máquinas e insumos industriais, além de incentivarem a ampliação e diversificação das exportações brasileiras. Também retomaram elementos da Política Externa Independente, cada qual a seu modo recolocando o país no caminho por maior autonomia nas arenas internacionais em prol dos interesses nacionais.

O período Costa e Silva e Médici foi caracterizado pelo acirramento do autoritarismo, tendo sido um período tenso de restrições e eliminação das liberdades democráticas. Se de um lado o regime recrudescia, por outro lado o crescimento econômico era retomado, dando início já em 1968 ao período conhecido como "milagre brasileiro" (1968-1973), de forte expansão do PIB e intenso dinamismo econômico. Para Tavares (2010, p. 118), a retomada do crescimento foi beneficiada pelas reformas da gestão Castelo, que recuperaram a capacidade de financiamento público, incentivaram o sistema financeiro privado, promoveram a construção civil e a indústria 
de material de transporte e mecânica, e incentivaram as exportações tradicionais e de manufaturados brasileiros. Além disso, havia ampla liquidez disponível nos mercados internacionais, facilitando o fluxo de capitais e tecnologias para o país.

A ideia do "Brasil potência" que inspirou o regime militar foi uma aspiração que na passagem dos anos 1960 para os 1970 se configurava cada vez mais concreta diante da percepção de que potências médias como a China e a Índia já atuavam como subcentros regionais, com poder de barganha ampliado pela sua trajetória de crescente dinamismo e pela tendência à multipolarização do cenário internacional. Em paralelo, em 1969 o presidente norte-americano lançara sua "Doutrina Nixon", pela qual os Estados Unidos deveriam transferir certas tarefas às potências regionais aliadas, como o Brasil. Na realidade, a chegada ao poder de governos de esquerda no Chile e no Peru, e a instabilidade política vivida pela Argentina e Uruguai, preocupavam o governo norteamericano, que identificou no Brasil um aliado para garantir a estabilidade e os interesses de Washington na América Latina.

No entanto, em 1973 o primeiro choque do petróleo minou os fundamentos econômicos do regime militar, que baseara o crescimento econômico e o processo de industrialização no uso de capitais e tecnologias externas, e principalmente, na importação de petróleo. Conforme Visentini (1998, p. 193), o parque industrial brasileiro importava em 1973 mais de 80\% de suas necessidades de consumo de petróleo e derivados, colocando a balança comercial em uma situação insustentável diante da explosão dos preços internacionais do petróleo.

$\mathrm{Na}$ realidade, a crise da economia internacional teve origens mais profundas e implicações de abrangência mais ampla, decorrentes da passagem da fase de expansão material do ciclo de acumulação norte-americano descrito por Arrighi (1994) para a de expansão financeira e crise. Se os anos 1950 e 1960 foram duas décadas de prosperidade e estabilidade econômica internacional, em que as empresas transnacionais expandiram suas atividades impulsionando o comércio e investimento mundial, os anos 1970 foram marcados pela redução das oportunidades de lucro no processo produtivo, com acirramento da competição econômica e migração do capital para as esferas financeiras.

O aumento da competição internacional esteve relacionado não só à redução dos lucros, mas também à tendência crescente dos preços de insumos e matérias-primas, levantando uma onda de protecionismo internacional. Como visto, a consequente corrida por oportunidades de lucro nos mercados financeiros dificultou a manutenção do 
sistema de taxas cambiais fixas de Bretton Woods e o controle da liquidez internacional pelos países individuais e pelo sistema centrado no banco central norte-americano e no FMI, levando ao aumento da instabilidade financeira mundial e ampliando as vulnerabilidades nacionais aos fluxos de capitais estrangeiros.

Essa nova realidade internacional influiu de modo decisivo no regime político e no modelo de desenvolvimento brasileiro, ao contribuir para o fim do "milagre brasileiro", cuja prosperidade e dinamismo haviam ajudado ao abafar as críticas ao regime entre 1968 e 1973. Assim, o governo Geisel iniciou em meio a uma difícil situação externa e interna, pois:

O fim do "modelo Médici" anulava um dos principais instrumentos legitimadores do regime, o sucesso econômico, sendo necessário, portanto, proceder à descompressão política, visando evitar uma radicalização e explosão [...] encerrar o ciclo militar antes que este sofresse um desgaste irreparável, comprometendo as forças armadas como instituição (VISENTINI, 1998, p. 198).

Desse modo, Geisel teve que iniciar a transição de um modelo de governo que reprimia o debate político, desviando o foco para as realizações econômicas, para um modelo quase oposto, em que a discussão política foi aos poucos sendo recuperada na tentativa de abafar os problemas econômicos. Conforme Visentini (1998, p. 199-200), além dos amplos setores da sociedade contrários ao regime que faziam manifestações, greves e atentados nas ruas, Geisel teve de enfrentar também a oposição da "linha-dura" do regime que era contra a abertura, e que multiplicava prisões arbitrarias, torturas e assassinatos.

Ademais, os problemas econômicos permaneciam carentes de rápida solução, tendo em vista as graves proporções que tomava o desequilíbrio nas contas externas. Nesse sentido, Castro e Souza (1988, p. 27) apontam que o governo brasileiro tinha duas opções de política econômica: financiar o desequilíbrio externo ou ajustar a economia nacional à restrição externa. $\mathrm{O}$ ajuste foi evitado por Geisel, que optou por manter o crescimento econômico e avançar o processo de industrialização em meio a um ambiente internacional desfavorável e aos custos de vultosos empréstimos externos. Se por um lado demonstrou-se assim o aumento da capacidade do Estado para promover ciclos de dinamização da economia brasileira em meio a um cenário adverso do comércio internacional, por outro lado este se apoiou sob um expressivo aumento da 
dependência financeira externa, cujas consequências foram duramente vividas pelo país na década posterior.

\subsubsection{Instrumentos da política econômica}

No início dos anos 1960, o potencial de acumulação da indústria brasileira crescera consideravelmente, graças aos aumentos de produtividade decorrentes dos investimentos e modernização ocorridos na década anterior. No entanto, conforme Tavares (1975, p. 166-167), esses ganhos de produtividade não foram traduzidos em aumentos salariais correspondentes, nem foram repassados aos preços, devido às assimetrias entre o poder de monopólio dos setores produtivos e entre empresas e sindicatos. Segundo a autora, até o golpe de 1964 o poder de compra salarial urbano conseguira manter-se graças às políticas populistas dos governos anteriores, mas com a flexibilização do mercado de trabalho e a contenção salarial da política econômica de Castelo, esse poder de compra esvaiu-se, penalizando a indústria de bens de consumo não durável.

Somando-se a esses fatores as medidas restritivas implementadas visando à estabilização inflacionária e a correção dos desequilíbrios fiscais, o resultado do governo Castelo foi uma profunda recessão interna, com falências e concordatas de inúmeras empresas nacionais e forte descontentamento social. Assim, o novo governo de Costa e Silva assumiu compelido a retomar o crescimento econômico e defender uma maior participação do empresariado nacional no projeto de desenvolvimento brasileiro.

Além disso, o problema inflacionário que acometera o governo anterior fora suavizado por essa conjuntura recessiva. Com um diagnóstico de que a inflação decorria de problemas na oferta brasileira, e não na demanda como ficara provado pelo fracasso das medidas contracionistas tomadas pelo governo anterior, o ministro da fazenda Delfim Neto concluiu que uma inflação de custos acometia o processo produtivo brasileiro, justificando o relaxamento das políticas fiscal e monetária, a concessão de isenções tributárias e a expansão do crédito para estimular o consumo e a produção nacionais.

Tal análise levou o novo governo a considerar o ajuste inflacionário suficiente, voltando a priorizar a retomada do crescimento econômico e do desenvolvimento 
industrial. Para isso, aponta Singer (1989, p. 61), "bastou simplesmente abrir as torneiras do crédito para que a economia se reanimasse e, a partir do segundo semestre de 1967, apresentasse taxas crescentes de expansão". Destarte, o autor avalia que o ciclo de expansão então iniciado teve como raiz a liberalização do crédito em uma economia com significativa capacidade ociosa, desemprego e custos salariais comprimidos após vários anos de recessão.

No mesmo ano, o governo lançou o Programa Estratégico de Desenvolvimento (PED), prevendo a retomada do crescimento econômico em duas fases: na primeira, a capacidade ociosa deveria ser ocupada por meio da expansão do crédito, do afrouxamento monetário e do tabelamento de juros. Na segunda fase, a capacidade produtiva deveria ser ampliada, por meio de investimentos em setores considerados dinâmicos (bens de capital, intermediários e de consumo duráveis, e as indústrias tradicionais). (Tavares, 2010, p. 138)

Nesse plano, o BNDE teve destacada atuação, tendo sua competência transferida para o Ministério do Planejamento pelo Decreto-Lei no 200 de 1967, e constituindo-se ao lado do Banco do Brasil, nas duas principais agências de fomento do PED. Tavares (2010, p. 146) destaca ainda o papel do recém-criado Instituto de Pesquisa Econômica Aplicada (IPEA), vinculado ao Ministério do Planejamento para a realização de estudos sobre os gargalos da economia brasileira.

No que tange ao incentivo ao capital privado nacional, para além das isenções e ampliação do crédito, foi de especial importância a instituição de uma política de Ciência e Tecnologia, incentivando a formação de pesquisadores, o financiamento do sistema de inovação e a modernização do empresariado nacional. Conforme Tavares (2010, p. 156), a participação do setor privado no financiamento das atividades de pesquisa e desenvolvimento $(\mathrm{P} \& \mathrm{D})$ era muito pequena e inexpressiva, tendo ficado até então a cargo do Estado. Com o PED, esse cenário começa a ser alterado.

O controle da inflação foi garantido por meio de uma combinação de medidas de controle de preços: de produtos, do crédito, e dos salários. No que diz respeito aos dois primeiros, estes foram introduzido por meio da criação em 1968 da Comissão Interministerial de Preços (CIP), colegiado subordinado ao Ministério da Fazenda que controlava os preços públicos (tarifas, câmbio e juros do crédito público) e privados, especialmente os de insumos industriais. Entretanto, na avaliação de Singer (1989, p. 62), o controle mais eficaz para conter a inflação foi o dos salários, que impedia o mecanismo da "espiral preços-salários" de se propagar. 
Embora a política salarial restritiva tenha acarretado em uma considerável deterioração do poder de compra das massas e a redução de sua demanda por bens de consumo não duráveis, Singer (1989, p. 108-113) avalia que os novos mecanismos de financiamento e crédito ao consumo introduzidos pelo PED estimularam a demanda da nova classe média e dos reduzidos grupos de elevada renda por bens de consumo duráveis, estimulando e dinamizando este setor industrial. Por outro lado, o mesmo autor aponta que o setor de bens de consumo não duráveis também foi estimulado, não por uma necessidade interna tendo em vista a política de arrocho salarial das camadas trabalhadoras, mas para atender a uma demanda externa ao país e à necessidade de equilibrar o balanço de pagamentos brasileiro, sobrecarregado pelas importações de maquinas e equipamentos necessários à produção industrial.

Assim, procurou-se garantir as importações necessárias aos objetivos do plano por meio de medidas de estímulo às exportações, como a adoção de subsídios e de um regime de minidesvalorizações cambiais, além da isenção de importações de máquinas sem similar nacional. Ademais, recorreu-se também ao capital estrangeiro, cujos empréstimos e financiamentos tornaram-se, conforme Singer (1989, p. 70), mais “fáceis" de levantar com o apoio político dos grandes centros financeiros internacionais ao novo regime instalando em 1964.

Nesse sentido, cabe ressaltar que, a partir de 1969, o volume de empréstimos e financiamentos ultrapassam o de investimentos diretos estrangeiros, tornando-se "a forma predominante de penetração do capital estrangeiro [...] o que vai ter por consequência a rápida expansão de nossa dívida externa" (SINGER, 1989, p. 72). O governo Costa e Silva manteve a abertura ao capital transnacional e o bom relacionamento com organismos financeiros internacionais. Assim, a equipe econômica do governo também conseguiu angariar recursos externos, como um empréstimo do BID de US\$ 50 milhões para projetos de desenvolvimento, a captação de US\$ 611 milhões junto a organismos internacionais para programas diversos, e um crédito de estabilização monetária de US\$ 85,5 milhões do FMI. (Visentini, 1998, p. 82),

Portanto, os instrumentos da política econômica de Costa e Silva consolidaram a famosa "tríplice aliança" entre Estado, capital privado nacional e capital estrangeiro, porém sob uma nova roupagem, ao direcionar parte da produção de bens de consumo não duráveis para a exportação e incentivar o consumo interno de bens de consumo duráveis, ao mesmo tempo em que reforçou a dependência da importação de insumos industriais e bens de produção. Conforme Singer (1989, p.73), houve um significativo 
aumento da importação de bens de capital nesse período, levando-o a aventar uma reversão da substituição de importações de máquinas e equipamentos, em um novo padrão de inserção internacional da economia brasileira como exportadora de primários e manufaturados de consumo não durável, e importadora de capitais financeiros e bens de capital.

Embora o Estado tenha conseguido retomar o crescimento econômico, ocupar a capacidade ociosa existente e continuar a instalação do parque industrial, a dependência brasileira do capital financeiro e produtivo estrangeiro foi preocupantemente agravada. Nas palavras de Singer (1989, p. 72):

O que impressiona, nesta evolução, é o grau de comprometimento crescente do processo de acumulação com a entrada de recursos externos. Apesar de todos os esforços de institucionalização de mecanismos de mercado para mobilizar o excedente interno, torna-se claro que a manutenção de elevadas taxas de crescimento econômico requer quantidades cada vez maiores de capital estrangeiro.

$\mathrm{Na}$ realidade, nesse período foi ficando cada vez mais perceptível a nova orientação da política econômica no sentido de abrir cada vez mais a economia brasileira para o exterior, seja pelo lado das crescentes exportações de bens de consumo não durável, seja pelo lado das também crescentes importações de capitais, máquinas e equipamentos. Em paralelo, Singer (1989, p. 75) aponta que a contrapartida de tal aumento da abertura econômica foi o aumento da vulnerabilidade externa, na medida em que a dependência de fatores exógenos à economia brasileira crescia.

No regime Médici, o ainda ministro da fazenda Delfim Neto anunciou uma nova opção estratégia do governo, por um “modelo agrícola-exportador”. Conforme Tavares (2010, p. 141-142), o objetivo era elevar o PIB e a renda per capita brasileira, acelerando o "desenvolvimento" econômico para superar rapidamente o subdesenvolvimento. Essa estratégia identificava a ampliação da receita com exportações e o fortalecimento da agricultura como "motores" que iriam prover a necessária ampliação do mercado interno no caminho para o desenvolvimento.

Do lado do ministério do planejamento, os objetivos do "desenvolvimento" seriam buscados por meio do Primeiro Plano Nacional de Desenvolvimento (IPND), que visava ampliar também a pauta de manufaturados exportados. Para isso, diagnosticava ser necessário "modernizar" a economia para aumentar a produtividade e a competitividade dos produtos brasileiros no exterior. A "modernização" seria 
alcançada por meio de um Plano Básico de Desenvolvimento Científico e Tecnológico, que centralizaria o processo de inovação nacional, prevendo medidas de modernização do Estado e ações de incentivo à inovação de empresas nacionais, de transferência e aquisição de tecnologias, de qualificação de pessoal de nível superior e de reestruturação da carreira de pesquisador. Além disso, o BNDE passou a ter um papel central como impulsionador da empresa nacional, capacitando-a e oferecendo mecanismos financeiros para subsidiar a sua "modernização" e "reorganização".

Nesse sentido, Singer (1989, p. 133-134) aponta que a partir de 1970 a capacidade ociosa existente fora se esgotando, o que diante da impossibilidade de ampliar e melhorar a capacidade produtiva de modo mais imediato, levou o governo a aproveitar a conjuntura internacional favorável para importar os bens de capital e insumos industriais necessários, ampliando sua capacidade de importação por meio da expansão das exportações e das entradas de capital estrangeiro. Os "pontos de estrangulamento" restantes que poderiam refrear o desempenho da economia brasileira foram cobertos por meio de um crescente comprometimento externo, em que os empréstimos e investimentos diretos do exterior permitiram sustentar os déficits nas contas externas, ao mesmo tempo em que contribuíram para um expressivo aumento da dívida externa.

Desse modo, apesar do forte crescimento e dos significativos investimentos na modernização da infraestrutura econômica e na instalação da indústria pesada, o período foi caracterizado por uma forte expansão do endividamento público, especialmente depois que o financiamento do déficit do governo, tradicionalmente coberto pela emissão de moeda, passou a ser atendido a partir de 1969 pela colocação líquida de títulos da dívida pública federal (ORTNs e LTNs). (LAGO, 2011, p. 254-255)

Portanto, o governo Médici confirmou o "modelo" caracterizado, conforme sumarizado por Singer (1989, p. 163), por:

[...] abertura da economia ao exterior, mediante estímulos às exportações e ampla importação de capital, tanto sob a forma de investimentos como de empréstimos; expansão do credito ao consumidor; estimulo à poupança interna mediante a correção monetária das taxas de juros; política salarial e trabalhista capaz de proporcionar às empresas mão-de-obra barata, abundante e disciplinada.

Em particular, destacou-se o significativo crescimento da dependência de máquinas, equipamentos e insumos industriais, principalmente o petróleo importado, 
determinando um crescente comprometimento com o capital estrangeiro, tanto o financeiro quanto o produtivo. O consequente aumento da vulnerabilidade externa foi duramente evidenciado com o primeiro choque do petróleo de 1973, que comprometeu seriamente esse modelo, de modo direto ao triplicar os preços de uma importante fonte de energia da economia brasileira, implicando em déficit comercial e dificuldades para importar; e indireto ao comprometer as balanças comerciais de todos os países importadores de petróleo, desenvolvidos e subdesenvolvidos, reduzindo de forma significativa o espaço internacional de absorção das exportações brasileiras.

Os limites desse "modelo" de crescimento com recurso ao capital externo foram assim evidenciados pelas implicações da crise internacional, ao demonstrar que a vulnerabilidade externa da economia brasileira continuava presente, apenas mudara de tipo e forma, passando a se manifestar pela dependência do fornecimento de petróleo, insumos industriais e capitais estrangeiros. Por outro lado, a liquidez internacional abundava, tendo os anos 1970 sido caracterizados pela fase de expansão financeira do ciclo de acumulação norte-americano. Assim, o governo Geisel pode optar pela continuidade do processo de industrialização e da expansão econômica, aproveitando para isso a ampla liquidez disponível nos mercados internacionais. Em vez de realizar um ajuste recessivo em acompanhamento à crise econômica internacional, o governo iniciou um novo ciclo de crescimento e dinamismo, possibilitando o descolamento da economia brasileira com relação ao cenário desfavorável da economia mundial.

Na avaliação de Castro e Souza (1988, p. 27-31), a opção por continuar o crescimento e não fazer o ajustamento trazia implícito o diagnóstico do caráter transitório da crise do petróleo, e implicou na contração de expressivos empréstimos externos. Entretanto, o autor ressalta que não se tratou de uma continuidade do modelo de sustentação do crescimento por meio da "captação da poupança externa" que caracterizou o período anterior de 1968 a 1973, na medida em que o novo governo se propôs a combater a vulnerabilidade que afligia a economia brasileira.

$\mathrm{Na}$ realidade, para esses autores, o II PND lançado por Geisel e o ministro do Planejamento João Paulo dos Reis Velloso constituiu-se em uma verdadeira "correção de rota" (CASTRO E SOUZA, 1988, p. 31) do processo de desenvolvimento. Embora o objetivo final tenha permanecido o mesmo, de construção de uma "economia industrial moderna", a política econômica buscou solucionar a grave vulnerabilidade externa manifestada pela dependência de insumos e equipamentos industriais importados, 
mobilizando por meio da ação estatal recursos e investimentos de modo a conquistar um autoabastecimento interno.

Conforme Tavares (2010, p. 161), o plano previa duas estratégias interdependentes para isso: "a construção de um novo padrão de industrialização calcado na indústria de base, e o fortalecimento progressivo do capital privado nacional". A primeira estratégia tinha como objetivo principal tornar o país autossuficiente em insumos básicos e energia, eliminando assim essa fonte importante de vulnerabilidade externa da economia brasileira. Nesse plano, o Estado iria encabeçar um programa no qual estavam previstos importantes projetos de estímulo à produção nacional de insumos industriais, além de investimentos na melhoria da infraestrutura produtiva e na diversificação das fontes de energia. Pretendia-se assim concluir a instalação da indústria pesada e do setor de bens de capital e reduzir a dependência energética do petróleo importado. Para isso, o plano previa a construção de hidrelétricas e usinas nucleares, o incentivo à produção nacional de petróleo, o estímulo ao uso do álcool como combustível, e a capacitação tecnológica em setores como a informática e a petroquímica.

A segunda estratégia advinha do diagnóstico de que o capital nacional era a "pata fraca" do tripé formado por Estado, capital estrangeiro e capital privado nacional. Segundo Tavares (2010, p. 162), o modelo tomado pelo governo eram as empresas japonesas, empresas nacionais fortes e capazes de gerar tecnologias e formar conglomerados, contribuindo para a construção de uma nova potência. Assim, o plano envolveu um projeto de fortalecimento da empresa nacional e desenvolvimento tecnológico, prevendo a criação de agências estatais e fundos setoriais de apoio ao segmento.

O BNDE teve participação essencial no plano, chegando a elaborar sua própria programação de projetos e investimentos, o $1^{\circ}$ Plano Quinquenal de Ação, voltado para incentivar a indústria de base e de capital, a infraestrutura, as empresas privadas nacionais e o desenvolvimento tecnológico, além de gerar oportunidades de exportações. No que tange à empresa privada nacional, foram criados mecanismos de alavancagem do capital privado, com a criação de subsidiárias do BNDE para participar minoritariamente do capital de risco dessas empresas, tomar debêntures em ações e prestar garantias de subscrição; além da instituição de novas linhas de financiamento para aumento de capital e subscrição de ações em oferta pública. Assim, a administração das empresas apoiadas não teria ingerência administrativa do Sistema 
BNDE, inaugurando um novo tipo de intervenção que não tirava o controle dos empresários, mas exigia a adoção de um comportamento compatível com a condição de capital aberto. (TAVARES, 2010, p. 165-171)

Assim, tendo em vista o fortalecimento da capacidade de autofinanciamento das empresas estatais, Tavares (2010, p. 175) aponta que, com o II PND, o BNDE consolidou um novo perfil voltado para o setor industrial privado, promovendo uma verdadeira doação de recursos públicos ao setor privado. $\mathrm{Na}$ visão da autora, isso implicou na:

[...] transferência da fragilidade financeira do setor privado para o setor público, uma vez que tais políticas, implementadas de início para reduzir a fragilidade financeira do setor privado durante o processo de aceleração inflacionária, provocaram um enfraquecimento da situação financeira do BNDE. O rombo, por sua vez, foi ressarcido pelo Tesouro Nacional e contribuiu para o posterior processo de deterioração das finanças públicas. (TAVARES, 2010, p. 177)

Quanto ao objetivo de superação dos desequilíbrios externos, o II PND logrou no longo prazo reduzir as importações de bens de capital e insumos básicos, além de reduzir a dependência energética externa e aumentar as exportações. No entanto, os incentivos fiscais, creditícios e cambiais envolvidos tiveram seus custos, que se expressaram por meio da deterioração financeira do Estado, cujos déficits eram financiados por meio de empréstimos externos, recorrendo à ampla liquidez internacional disponível nesse período.

Desse modo, o governo conseguiu manter o crescimento econômico e a criação de empregos, instalando ainda com relativo sucesso os setores industriais de insumos básicos e bens de capital. Como avaliam Castro e Souza (1988, p. 32-33), foi um esforço extremamente ousado do governo brasileiro, tendo em vista a alteração da rota do desenvolvimento industrial, que até então se fundamentava na indústria de bens de consumo, para setores que exigiam grande mobilização de capital e eram intensivos em energia, em meio a uma situação de crise internacional e choque do petróleo. Tratavase, portanto, de um plano voltado à solução do problema energético brasileiro no longo prazo, mas que envolvia o agravamento desse problema no curto e médio prazo. Ademais, o plano recorreu ao endividamento externo como meio de financiar esse esforço, incorrendo nas duras consequências das crises das dívidas dos anos 1980.

Em suma, os instrumentos da política econômica de inserção internacional da economia brasileira destes três governos militares foram: 
- Programa Estratégico de Desenvolvimento (PED - Costa e Silva):

- medidas de estímulo ao consumo e à produção visando ocupar a capacidade ociosa: expansão do crédito, isenções tributárias, afrouxamento monetário e de juros;

- incentivos às indústrias tradicionais e ao empresariado nacional;

- política de contenção salarial;

- entrada das estatais nos setores de petroquímica, siderurgia, mineração, eletricidade, comunicação e transportes;

- criação do Instituto de Pesquisa Econômica Aplicada (IPEA) em 1967;

- criação de uma política de Ciência e Tecnologia, incentivando a formação de pesquisadores e o financiamento do sistema de inovação;

- contração de empréstimos internacionais (US\$50 milhões do BID, US\$ 611 milhões de organismos internacionais diversos e US\$ 85,5 milhões do FMI);

- criação da Comissão Interministerial de Preços (CIP) em 1968 para controle dos preços públicos e privados;

- adoção de um regime de minidesvalorizações cambiais em 1968.

- Primeiro Plano Nacional de Desenvolvimento (I PND - Médici):

- incentivos à produção agrícola e às suas exportações;

- programação de investimentos visando modernizar a infraestrutura e indústria pesada;

- Política Tecnológica Nacional: medidas de modernização do Estado e das empresas nacionais, aquisição de tecnologias, qualificação de pessoal de nível superior e reestruturação da carreira de pesquisador;

- programas e criação de Centros de Tecnologia nos setores da Siderurgia, Petroquímica, Mineração, Transportes, Energia Elétrica, Comunicações, Tecnologia Nuclear e Pesquisa Espacial;

- grandes empreendimentos: ponte Rio-Niterói, barragens hidrelétricas de Itaipu, rodovia Transamazônica, Zona Franca de Manaus, estádios de futebol e plantas industriais;

- Programa de Modernização da Empresa Nacional e criação do Fundo de Desenvolvimento de Mercados de Capitais para incentivar a colocação de debêntures e ações pelas empresas nacionais; 
- financiamento do déficit público com a emissão de títulos da dívida pública federal (ORTNs e LTNs).

- Segundo Plano Nacional de Desenvolvimento (II PND - Geisel):

- tornar o país autossuficiente em insumos básicos e energia, e fortalecer o capital privado nacional.

- projetos de construção de hidrelétricas e usinas nucleares, de produção nacional de petróleo e de uso do álcool como combustível;

- projetos de fortalecimento da empresa nacional e desenvolvimento tecnológico, com a criação de agências estatais e fundos setoriais;

- 1 Plano Quinquenal de Ação do BNDE: medidas de incentivo à indústria de base e de capital, infraestrutura, empresas privadas nacionais e desenvolvimento tecnológico:

- criação de mecanismos de alavancagem do capital privado;

- criação de subsidiárias para apoiar o capital privado por meio da participação minoritária do capital de risco dessas empresas e da prestação de garantias de subscrição;

- criação de novas linhas de financiamento para aumento de capital de empresas nacionais e subscrição de ações em oferta pública.

\subsubsection{Instrumentos da política externa}

A política externa de Costa e Silva promoveu uma mudança de postura em relação ao governo anterior, refletindo outras leituras da posição brasileira no mundo e suas possibilidades de atuar com maior autonomia em prol de seu desenvolvimento econômico. Nas palavras de Martins (1975, p. 67-68), foi um “período de acordar [...] o pacto subimperialista não existia senão na imaginação, a estratégia de defesa coletiva e integral não gerou uma política hemisférica interdependente, mas, pura e simplesmente, uma política externa dependente”.

Por meio da "Diplomacia da Prosperidade", o governo de Costa e Silva resgatou o desenvolvimento como objetivo prioritário da política externa brasileira em detrimento da segurança, recuperou a soberania nacional pelo abandono da teoria da 
interdependência, voltou a posicionar o Brasil como nação do Terceiro Mundo e retomou o conflito Norte-Sul como eixo de atuação para a discussão dos interesses do desenvolvimento. A pobreza e o atraso foram reconhecidos como problemas piores do que a ameaça de comunismo, assim como a aliança com o Terceiro Mundo foi buscada como meio para reformar as injustiças do sistema econômico internacional diante da irrealidade do alinhamento político-ideológico entre Estados Unidos e URSS.

De certo modo, a diplomacia do governo Costa e Silva retomou alguns elementos da Política Externa Independente de Quadros e Goulart, como o uso da política externa como instrumento do desenvolvimento econômico, a perseguição dos interesses nacionais livre de ideologias e alinhamentos políticos, o universalismo e o foco no conflito Norte-Sul. No entanto, assim como a PEI encontrou limites externos e internos decorrentes das dificuldades de se libertar da influência norte-americana e as contradições estruturais brasileiras, a Diplomacia da Prosperidade também encontrou restrições à uma atuação mais autônoma em prol dos interesses nacionais, embora em grau menor e sob novas condições, implicando em alguns contrassensos em meio a um movimento geral de distanciamento do americanismo e de maior pragmatismo em sua condução.

Formulada pelo chanceler José Magalhães Pinto, a Diplomacia da Prosperidade não condicionava o desenvolvimento à ajuda externa, mas ao endogenismo do processo de acumulação de capital nacional, significando que a política externa deveria identificar e remover os obstáculos externos ao projeto nacional de desenvolvimento. Nesse sentido, Cervo e Bueno (2008, p. 383) apontam que as três principais vias de atuação identificadas por este chanceler foram o comércio exterior, a modernização tecnológica, e a atração de capitais. Assim, os instrumentos de política externa foram voltados para a reforma do comércio internacional e a ampliação dos mercados de exportação brasileira; a cooperação para a aquisição de tecnologias e conhecimentos visando a autonomia econômica; e o aumento e diversificação dos fluxos de capitais com melhores condições de pagamento para o país.

No campo multilateral, o Brasil aliou-se ao Terceiro Mundo, definindo-se como membro do grupo e defendendo a união dos povos "atrasados" contra os países ricos e avançados. A atuação brasileira na ONU foi marcada pela figura do embaixador Azeredo da Silveira, que defendeu ativamente a cooperação e solidariedade terceiromundista, criticando as desigualdades da estrutura econômica internacional e as políticas discriminatórias dos países ricos. Em 1968, os interesses do Terceiro Mundo 
foram defendidos na II Unctad de tal modo pela delegação brasileira que Azeredo foi escolhido presidente do Grupo dos 77 , ajudando a promover a primeira reunião desse grupo recém-criado com o objetivo de defender o desenvolvimento dos países atrasados. Além da ONU e do G77, a atuação de Azeredo da Silveira também foi destacada no GATT, em que o papel desse fórum em prol das relações comerciais dos países subdesenvolvidos foi criticado pelo embaixador, que propôs uma revisão de suas funções. (Visentini, 1998, p. 109)

Com relação à diplomacia regional, a política externa passou a defender uma integração horizontal da América Latina, abandonando as pretensões de subliderança regional do governo anterior, e afastou-se dos Estados Unidos, preterindo a OEA e elegendo a CECLA (Comissão Especial de Coordenação Latino-Americana) como instância preferencial de relacionamento regional, um foro exclusivamente latinoamericano criado sem a participação da potência hegemônica.

Como exemplos desse movimento, pode-se citar a Primeira Conferência dos Presidentes Americanos em Punta Del Este em 1967, quando as nações latinoamericanas colocaram como questão prioritária para a discussão coletiva a estruturação de um mercado comum latino-americano, contrariando os Estados Unidos que pretendiam cobrar posições políticas da região no contexto da Guerra Fria. Uma jogada semelhante foi realizada um ano depois na reunião dos chefes de Estado da OEA em Montevidéu, quando a criação do Mercado Comum Latino-Americano foi aprovada como projeto a ser erguido a partir da ALALC, junto com a do Mercado Comum Centro-Americano, até 1985.

Em 1969, o Brasil propôs a formação de uma frente latino-americana para negociar com os Estados Unidos as relações econômicas do hemisfério, por meio de uma reunião da CECLA cuja decisão seria apresentada à potência norte-americana. $\mathrm{O}$ afastamento de Washington produziu-se ainda pela crítica aos resultados da Aliança para o Progresso, avaliando os volumes de financiamento concedidos como insignificantes perante as necessidades da região e insuficientes para equilibrar os pagamentos das remessas de lucros e do déficit comercial com os Estados Unidos, além de terem péssimas condições de prazo e juros, contribuindo mais para o subdesenvolvimento da região do que para o seu desenvolvimento.

Além disso, o Brasil negou-se ainda a assinar o Tratado de Não-Proliferação Nuclear, posicionou-se contra as propostas norte-americanas de criação de uma Forca Interamericana de Paz e de internacionalização da Amazônia, e enfrentou os Estados 
Unidos nos contenciosos pela exportação de café solúvel, têxteis e manufaturados brasileiros para os mercados norte-americanos.

Na realidade, conforme Visentini (1998, p. 93-94), o Brasil mantinha a retórica das "relações especiais" com a potência norte-americana, buscando administrar os conflitos por meio da negociação bilateral e da aquisição de maior poder de barganha pela diversificação das relações exteriores com outros países. Desse modo, apesar da agenda bilateral entre os dois países ter sido repleta de divergências, o diálogo pode manter-se em termos razoáveis. Em parte, isso se deve também ao bom relacionamento mantido com relação ao capital estrangeiro e a organismos como o FMI, com os quais a relação foi de abertura e cooperação.

Entretanto, em nossa visão, as dificuldades enfrentadas pela política econômica em decorrência da crescente dependência dos capitais produtivos e financeiros internacionais acabaram abrindo espaço para uma atuação mais autônoma da política externa, que buscou auferir meios alternativos no cenário internacional de apoiar os objetivos de "desenvolvimento" do governo. Além disso, a capacidade da política externa brasileira para atuar com maior flexibilidade perante a potência norte-americana foi beneficiada pelas dificuldades que esta já começava a enfrentar no declínio de sua fase de expansão material, em um mundo crescentemente multipolarizado.

Ainda na América Latina, Costa e Silva continuou também a política de aproximação bilateral dos países latino-americanos, com vistas à cooperação técnica e econômica. Com a Argentina, foram assinados dois acordos sobre o aproveitamento e conservação dos recursos naturais do Atlântico Sul, além de acordos comerciais, de intercâmbio cultural e técnico-cientifico, e um projeto de integração dos países da Bacia do Prata (Brasil, Argentina, Bolívia, Paraguai e Uruguai), consubstanciado em 1969 pela assinatura da Carta da Bacia do Prata. Aproximou-se também do Uruguai, com o qual inaugurou a Ponte da Concórdia e assinou a Declaração Conjunta Brasil-Uruguai sobre Intercâmbio Comercial; do Paraguai, com o qual inaugurou a rodovia BR-227 integrada à estrada Assunção-Paranaguá; da Bolívia e do Peru, com os quais assinou a Ata de Rio Branco, visando abrir rodovias entre as capitais dos três países; e do Chile e do México, trocando visitas diplomáticas e manifestações de cooperação técnica e econômica.

No que diz respeito às relações com a URSS, a postura foi bastante semelhante à do governo anterior, mantendo a aproximação estritamente econômica e técnica. Cumpre destacar ainda que, como alternativa aos Estados Unidos, o Brasil procurou 
aproximar-se bilateralmente dos países europeus, com os quais promoveu diversas iniciativas de cooperação técnica e econômica. Em especial, foram muito importantes as ações empreendidas junto à Alemanha Federal, da qual obteve dois empréstimos de 54 e 90 milhões de marcos alemães para investimentos na indústria manufatureira, na Companhia Vale do Rio Doce e na Usina Hidrelétrica de Ilha Solteira, além de um acordo para cooperação técnica e cientifica, envolvendo o desenvolvimento de recursos energéticos, agrícolas e aeronáuticos. Também se aproximou da França, Portugal, Itália e Reino Unido, com os quais acordou mecanismos de cooperação bilateral técnica, econômica e financeira.

As relações econômicas internacionais do país ainda foram estreitadas com o Oriente Médio e a Ásia, com a assinatura em 1968 do primeiro acordo comercial brasileiro com a Índia, a criação em 1969 do Grupo Coordenador do Comércio com Países Árabes (Loarabe) para aquisição de petróleo e exportação de produtos brasileiros, e a assinatura de acordos com a Turquia e a Argélia.

Portanto, os instrumentos da Diplomacia da Prosperidade retomaram o uso da política externa como um instrumento em prol do desenvolvimento, distanciando-se dos alinhamentos aos Estados Unidos e criticando junto ao Terceiro Mundo a estratificação econômica mundial. No entanto, a Diplomacia da Prosperidade também teve suas contradições, refletindo dificuldades do país para atuar com maior autonomia no cenário internacional e de modo livre de influências externas: foi o caso da manutenção do apoio ao colonialismo lusitano na África, inclusive criando o Dia da Comunidade LusoBrasileira no dia 22 de abril, e da exclusão de sua aliança desenvolvimentista de países socialistas como a China, a Coréia do Norte e o Vietnã do Norte.

A principal inflexão promovida pelo regime Médici com relação à política externa de Costa e Silva, conforme Visentini (1998, p. 134-140) deu-se em duas frentes: na interpretação do posicionamento brasileiro no mundo, que levou a uma atuação internacional a partir de outras perspectivas; e na atuação menos politizada e mais pragmática. No primeiro caso, Médici e seu chanceler Gibson Barboza interpretavam a estrutura capitalista mundial como naturalmente caracterizada pela exploração imperialista, em que o Brasil deveria tornar-se uma potência de destaque pertencente ao Primeiro Mundo. Nesse sentido, a união aos "povos atrasados" do Terceiro Mundo era vista como inadequada por pressupor a destruição dessa estrutura, posto que o atendimento dos seus interesses significaria o fim da ordem capitalista mundial. Nesse 
sentido, nem o Brasil seria parte do Terceiro Mundo, nem o Terceiro Mundo seria uma verdadeira força política no cenário internacional ${ }^{83}$.

Essa nova formulação pressupunha uma separação, elaborada pelo embaixador na ONU Araújo Castro, entre "política externa brasileira" (PEB), referente às diretrizes estruturais das relações exteriores brasileiras, e a "política internacional do Brasil" (PIB), referente às práticas de atuação brasileira nas questões internacionais. Conforme Visentini (1998, p. 140), enquanto a primeira reafirmava os princípios de igualdade soberana das nações, pacifismo, não intervenção, autodeterminação dos povos e manutenção de relações amistosas com os Estados Unidos; a segunda estabelecia a racionalidade e o cálculo dos custos e benefícios na atuação internacional do país, independente de ideologias e subordinando os princípios estruturais da política externa brasileira a um "realismo pragmático".

Assim, o cálculo racional de custo-benefício deveria se sobrepor aos princípios da política externa brasileira, inclusive o que diz respeito ao relacionamento amistoso com Washington, com o qual se esperava estabelecer um diálogo proveitoso, porém sem subordinar os interesses do projeto de "Brasil potência". Essa postura foi facilitada pela conjuntura internacional e regional, em que a hegemonia enfraquecida dos Estados Unidos precisava da colaboração brasileira para, no âmbito da Doutrina Nixon, garantir seus interesses na América Latina, "ameaçada" pelos governos de esquerda do Chile e Peru e pela instabilidade política da Argentina e do Uruguai.

Destarte, a cooperação com os Estados Unidos deveria ser buscada primordialmente no âmbito bilateral, porém de modo racional e sem prejudicar os interesses nacionais. Nesse sentido, os pontos de atrito eram inevitáveis, como foi o caso da ampliação do mar territorial brasileiro em 1970 com oposição de Washington, da recusa a assinar o TNP no mesmo ano e dos empecilhos norte-americanos às exportações brasileiras de têxteis, café solúvel e calçados.

Por outro lado, o Brasil forneceu o apoio esperado pelos Estados Unidos aos golpes de Estado no Chile, Uruguai e Bolívia, cumprindo o papel esperado pela Doutrina Nixon de potência média regional aliada à potência hegemônica. Desse modo, a postura dos Estados Unidos foi relativamente tolerante frente ao regime Médici, com a

\footnotetext{
${ }^{83}$ Conforme Martins (1975, p.82-83), Barbosa explicava a ilusão do Terceiro Mundo com base em três falácias: a do subdesenvolvimento autogênito (o subdesenvolvimento como algo independente do desenvolvimento), a do paternalismo (o desenvolvimento como algo alcançável por meio de alianças com os países em desenvolvimento) e a gradualística (o desenvolvimento como algo alcançável no longo prazo).
} 
ajuda econômica ao país sendo restabelecida e a realização de inúmeras iniciativas bilaterais, com assinatura de acordos entre os dois países para a cooperação em áreas científicas, militares, técnicas e econômicas, além de inúmeras trocas de visitas de autoridades e oficiais de ambos os governos. (VISENTINI, 1998, p. 147-151)

No caso da América Latina, o país se afastou da atuação internacional conjunta com seus vizinhos, dando preferência ao relacionamento bilateral. Desse modo, obstou os trabalhos para a criação de um mercado comum na região, defendendo em seu lugar o fortalecimento da ALALC; e promoveu iniciativas de cooperação bilateral com os países da região. Assim, assinou em 1973 uma Ata de Cooperação com a Bolívia para compra de gás, um Acordo de Cooperação com a Colômbia para criação de uma Binacional do Carvão, e projetos de desenvolvimento com o Uruguai das Bacias da Lagoa Mirim e do rio Jaguarão. Com o Paraguai, o Brasil assinou um Tratado de Aproveitamento Hidrelétrico do Rio Paraná (Tratado de Itaipu), além de acordar a construção de estradas e pontes interligando os dois países, e o desenvolvimento de projetos de assistência técnica visando estruturar o mercado de capitais e o mercado habitacional paraguaio.

No entanto, com outros países como o Chile e a Venezuela, a política externa brasileira junto aos Estados Unidos levantou críticas e desconfianças, especialmente após o apoio brasileiro aos golpes de Estado na Bolívia em 1971 e no Chile em 1973. Em específico, a Argentina enfrentava grande instabilidade política interna, dificultando as negociações relacionadas à Hidrelétrica de Itaipu - que só foram sanadas após visita ao Brasil do presidente argentino em 1972, firmando uma Declaração Conjunta BrasilArgentina de cooperação e seis acordos de colaboração entre os dois países.

No plano multilateral, o embaixador Araújo Castro defendeu a proposta de reforma da Carta das Nações Unidas, criticando as tentativas dos países avançados de mantê-la inalterada e denunciando a necessidade de todos aceitarem uma responsabilidade coletiva no desenvolvimento econômico dos países "atrasados". No entanto, essa atuação nos fóruns multilaterais não se deu mais em conjunto com o Terceiro Mundo, mas de forma independente. Assim, o Brasil participou apenas como observador da reunião preparatória da Conferência dos Países Não-Alinhados em 1970, assim como da V Conferência de Chefes de Estado e Governo dos Países NãoAlinhados em 1973.

A aproximação dos países do Terceiro Mundo seguiu a estratégia bilateral, assim como as iniciativas junto ao Primeiro Mundo, sempre buscando explorar as 
possibilidades de cooperação econômica, técnica e científica. No que diz respeito aos países capitalistas desenvolvidos, essa aproximação envolveu não apenas os países da Europa Ocidental, com destaque para Alemanha e França, mas também o Japão e o Canadá. Também se aproximou, de modo estritamente técnico e econômico, dos países socialistas europeus, com os quais estreitou o intercâmbio comercial e a cooperação técnica, e dos países da África Ocidental e do Oriente Médio.

Assim, foi um período de intensa aproximação bilateral com diversos países europeus, árabes, africanos e asiáticos, com inúmeras trocas de visitas de oficiais e autoridades governamentais, assinatura de acordos de cooperação, e outras iniciativas bilaterais. Contudo, nas palavras de Visentini (1998, p. 163): "a política mundial do Brasil ainda era tímida e presa ao passado", especialmente no que diz respeito às suas posições com relação a Portugal, Cuba e a República Popular da China. Em nossa visão, a "timidez" com relação a esses países esteve muito mais relacionada à equação de custos e benefícios envolvida, onde os ganhos antevistos não compensavam os riscos decorrentes de contrariar interesses norte-americanos e de outros países do Primeiro Mundo.

Tomando como exemplo as relações com Portugal e a África, de um lado, manteve-se a política de solidariedade luso-brasileira e o apoio na questão das "províncias ultramarinas" na ONU, posicionando-se junto aos países colonialistas; de outro lado, tendo em vista o potencial de cooperação econômica e técnica com os países africanos, buscou-se a aproximação destes por meio de iniciativas bilaterais. Nesse sentido, Visentini (1998, p. 170) aponta ter se iniciado uma importante alteração no que diz respeito ao problema do colonialismo. Segundo o autor, as relações bilaterais com Portugal passaram a ser separadas entre o "Portugal metropolitano", com o qual se deveria estreitar os laços econômicos e culturais, e o "Portugal colonialista", com o qual se deveria evitar o envolvimento político e militar. Assim, foram acordados a convenção sobre igualdade de direitos entre brasileiros e portugueses, além de medidas de cooperação econômica, técnica e militar entre os dois países e a trasladação para o Brasil dos restos mortais de Dom Pedro I. Mas por outro lado, o Brasil cancelou manobras navais conjuntas com Portugal, proibiu a venda de armas a esse país, excluiu as colônias portuguesas da visita do chanceler brasileiro à África em 1972 e evitou associação com Portugal na exploração do petróleo angolano e na abertura de entrepostos comerciais em Angola e Moçambique. 
Paralelamente, apesar de votar ao lado dos países colonialistas na ONU, o Brasil se absteve nas questões de condenação do colonialismo, da apartheid e da discriminação racial. Ainda assim, empreendeu ações de aproximação bilateral com os países africanos, por meio de trocas de visitas de autoridades e delegações, assinatura de acordos econômicos e realização de estudos sobre as possibilidades de cooperação. Nesse sentido, destacou-se a visita de 1972 do chanceler Barboza ao Senegal, Costa do Marfim, Nigéria, Camarões, Zaire, Togo, Daomé, Gana e Gabão, visando identificar os interesses em comum no Atlântico Sul, e estimular a cooperação econômica, cultural e técnica com a região. Conforme Visentini (1988, p. 180), essa visita enfrentou forte oposição portuguesa e do Ministério da Fazenda, que privilegiava a cooperação com Portugal e suas colônias na África, tendo sido "um dos primeiros esforços concretos da diplomacia brasileira junto aos países atlânticos da África".

Entre seus resultados, o chanceler acertou acordos bilaterais de comércio e cooperação técnica e cultural nos países visitados, com destaque para a exploração brasileira de petróleo e minérios no Gabão, além de discutir a possibilidade de intermediação pelo Brasil na questão do colonialismo português no Senegal e de exploração do mercado consumidor na Nigéria. Também foram consequências dessa visita a criação do Museu Afro-Brasileiro em Salvador e do Programa de Cooperação Cultural com a África, além do restabelecimento de relações diplomáticas com Guiné, Serra Leoa e Gabão, e a realização de inúmeras missões brasileiras ao continente africano: da Escola Superior de Guerra, da Confederação Nacional da Indústria, da Câmara de Comércio Afro-Brasileira, da Eletrobrás e do sindicato da Indústria Farmacêutica.

A orientação pelo cálculo de custos e benefícios também se fez sentir no caso do Oriente Médio, em que as relações foram pressionadas pelas necessidades de garantir o fornecimento de petróleo e ampliar os mercados de exportação do Brasil. Assim, a diplomacia brasileira transitou na questão do conflito árabe-israelense entre o apoio à Israel e o apoio à Liga Árabe, em uma posição equidistante que promoveu a aproximação a ambos os lados. Destarte, foi assinado um acordo comercial para compra do petróleo iraquiano em troca da exportação de produtos brasileiros, além de ações da Petrobras no Egito, na Líbia e no Kuwait, visando garantir o suprimento de petróleo ao Brasil. Com Israel, o país acertou acordos de cooperação técnica e militar, principalmente para a irrigação de áreas atingidas pela seca. 
Portanto, é possível identificar elementos de continuidade da política externa de Médici com relação à diplomacia de Costa e Silva, embora pautada por um redimensionamento da interpretação da posição brasileira no mundo e do modo de tratar as questões internacionais, moderando o conteúdo dessa política externa para enfatizar o relacionamento bilateral e o cálculo de custos e benefícios na sua busca pelo desenvolvimento. Os instrumentos da diplomacia de Médici, ao contrário de Costa e Silva, não aspiravam mudar a ordem mundial, apenas a posição relativa do Brasil nela, visando alçar o país à condição de potência sem alterar as relações assimétricas de dominação e exploração do sistema. O objetivo não era confrontar o mundo capitalista, mas explorar suas oportunidades de ascensão e ganho de poder.

Em meados dos anos 1970, tanto a conjuntura externa de crise econômica quanto a dependência da importação de petróleo e de capitais estrangeiros, decorrente do modelo de desenvolvimento associado, pressionavam por ajustes na política econômica. No entanto, diante das restrições externas, o governo optou por manter o crescimento e continuar o processo de industrialização com o objetivo de substituir as necessidades de importação da economia por produção nacional. Essa reação do governo Geisel implicou em uma redefinição da política externa, que deveria tornar-se mais ágil e eficiente para apoiar o ambicioso projeto de manutenção do crescimento econômico e construção da autossuficiência nacional de insumos básicos e energia, em meio à crise internacional do petróleo e do comércio mundial.

Assim, a diplomacia formulada como um "Pragmatismo Responsável" pelo chanceler Azeredo da Silveira, teve de assumir uma postura mais autônoma e flexível no cenário internacional em prol dos interesses nacionais, pressionada pelas dificuldades exógenas e endógenas à economia brasileira. Como apontam Lima e Moura (1982, p. 349), se com Costa e Silva a configuração do Brasil como uma potência média em um cenário internacional multipolar levara a uma diplomacia caracterizada por um "terceiro-mundismo difuso", e com Médici, gerara um projeto de "Brasil-potência"; com Geisel isso se expressaria por uma política pragmática, conferindo ao país maior autonomia nas questões internacionais para defender seus interesses e enfrentar a crescente vulnerabilidade e dependência de fatores externos.

$\mathrm{Na}$ realidade, o "Pragmatismo Responsável” representou quase uma ruptura perante às políticas externas empreendidas por Costa e Silva e Médici, na medida em que se libertou dos laços ideológicos e alinhamentos automáticos para adaptar-se com mais flexibilidade e autonomia ao cenário internacional em prol dos interesses 
nacionais. Nesse sentido, o "Pragmatismo Responsável" guarda semelhanças com a Política Externa Independente, especialmente no que diz respeito à concepção da diplomacia como um instrumento do desenvolvimento relacionado ao exercício da autonomia. Entretanto, as semelhanças encontram-se mais no campo da retórica e do discurso, tendo em vista que ambas foram formulações desenvolvidas a partir de realidades próprias e específicas, constituindo-se em respostas a elementos conjunturais particulares de cada período.

A política externa de Geisel finalmente abandonou de fato as restrições políticas e ideológicas que balizavam a política externa brasileira, operando com maior flexibilidade e pragmatismo no cenário internacional, enquanto as diplomacias de Costa e Silva e Médici apenas apontaram em graus diferentes para um rompimento do alinhamento quase-automático com os Estados Unidos. De um lado, tal flexibilização foi beneficiada pela ampliação do horizonte internacional de potências alternativas aos Estados Unidos, pela superação da bipolaridade Leste-Oeste e pelo declínio relativo do poderio norte-americano. Mas, por outro lado, também foi pressionada pelo cenário internacional de crise econômica e retorno ao protecionismo comercial, e pelas necessidades da nova inserção internacional da economia brasileira como nação industrializada mas dependente da importação de insumos industriais, capitais e tecnologias estrangeiras.

Portanto, a política externa brasileira deveria se definir pelo tratamento de cada problema ou questão particular visando o interesse nacional, sem ideologias e preconceitos, ampliando parcerias e aproveitando as oportunidades do cenário mundial. Desse modo, completou-se finalmente "a mudança de ênfase da área de segurança para a área de desenvolvimento" (PINHEIRO, 1994, apud Visentini, 1998, p. 206), com as formulações de segurança passando a interferir cada vez menos nas decisões de política externa.

No que tange às relações com os Estados Unidos, essa política se caracterizou pelo posicionamento de modo contrário à relação considerada infrutífera com a potência norte-americana, enfatizando o "não-alinhamento automático" e não hesitando em buscar alternativas à Washington na busca de seus interesses, mesmo quando estes se chocavam com os interesses norte-americanos. Desse modo, as relações bilaterais tornaram-se mais complexas e conflituosas, na medida em que o Brasil promoveu iniciativas efetivas de escape à zona de influência norte-americana. 
O exemplo paradigmático foi a assinatura do Acordo Nuclear com a Alemanha Ocidental em 1975, sob pesadas críticas e pressões dos Estados Unidos. Segundo Lima e Moura (1982, p. 354), Washington tradicionalmente se recusava a transferir tecnologias sensíveis para o Brasil, além de a partir dos anos 1960 ter começado a limitar a venda de equipamentos militares e obstar a ajuda pelo Acordo Militar BrasilEUA. As pressões norte-americanas em relação ao acordo com a Alemanha acabaram levando ao rompimento por Geisel do Acordo Militar Brasil-EUA em 1977, e tornando a saída da órbita de interferência militar dos Estados Unidos um objetivo fundamental da política externa brasileira.

De modo análogo, quando os Estados Unidos buscaram o apoio de Brasília para discutir a questão da segurança no Atlântico Sul e as intervenções na América Central, o Brasil priorizou a aproximação com a África, condenando o colonialismo e a apartheid, e buscou o entendimento com os países da América Latina, defendendo a nãointervenção. No campo econômico, as divergências se multiplicaram, principalmente em relação ao protecionismo dos Estados Unidos contra as exportações de manufaturados brasileiros, em contraste com os pleitos liberalizantes antes feitos em prol de suas transnacionais.

Com relação aos demais países do Primeiro Mundo, inicialmente buscou-se continuar a política de aproximação, mesmo como forma de ampliar o espaço de autonomia perante os Estados Unidos por meio da diversificação das relações internacionais com outras potências capitalistas. Assim, as relações bilaterais foram incrementadas com diversos países da Europa Ocidental, o Japão e o Canadá, com trocas de visitas oficiais, acordos comerciais e de apoio técnico, além da negociação de empréstimos e financiamentos para projetos de desenvolvimento brasileiros.

$\mathrm{Na}$ realidade, tratava-se de uma política que foi caracterizada por Lima e Moura (1982, p. 352) como uma de "dupla inserção brasileira internacional”, na medida em que Geisel buscou, pelo menos de início, separar dois tipos de postura, intercaladas conforme a percepção do fórum de encaminhamento mais adequado de seus interesses nacionais. Assim, em algumas questões preferia-se atuar nos foros multilaterais, portando-se como Terceiro Mundo, como um país em desenvolvimento que deveria receber benefícios para o seu progresso econômico; enquanto em outras questões preferia-se a atuação como país industrializado apto a se relacionar de modo equivalente com os países ricos, como no caso dos mecanismos de consultas políticas com os membros do Primeiro Mundo. 
No entanto, para além do incremento comercial e da cooperação técnica e científica, o Brasil buscava principalmente o ingresso no clube dos países ricos, aspiração que foi frustrada diante da crescente articulação entre os países do Primeiro Mundo para fazer frente ao fortalecimento do grupo dos países em desenvolvimento. Para Lima e Moura (1982, p. 357):

[...] o Brasil foi, política e conceitualmente, "empurrado" para o Terceiro Mundo pelos países ocidentais e desenvolvidos. Por isso sua diplomacia tem se esmerado em produzir argumentos de apoio à existência do 'Sul' como realidade política e econômica e à sua capacidade de atuar em bloco face aos países industrializados do Ocidente.

Desse modo, a atuação brasileira foi voltando-se crescentemente para os fóruns multilaterais junto ao Terceiro Mundo, com o Brasil assumindo maior protagonismo no pleito dos países em desenvolvimento e na denúncia das tentativas dos países desenvolvidos de congelar a estrutura de poder mundial. Temas sensíveis antes contornados passaram a ser abordados de modo claro e objetivo, como a defesa da descolonização dos países africanos e da retirada de Israel dos territórios palestinos. Somente no caso de Cuba, as relações continuaram a ser moderadas por questões de segurança pelo regime militar, com o Conselho de Segurança Nacional limitando a atuação da política externa brasileira nas questões consideradas nocivas à segurança nacional.

Com relação à África, o bom relacionamento beneficiaria o Brasil no plano multilateral tendo em vista o peso das delegações africanas no Terceiro Mundo, e também no relacionamento com os países árabes, dos quais a África negra era aliada, além de representar um significativo mercado potencial para a exportação de manufaturados brasileiros. Assim, em 1974 Azeredo da Silveira defendeu na ONU a descolonização, com o Brasil reconhecendo a independência de Guiné-Bissau e, em 1975, a de Angola.

Apesar da aproximação ter sido dificultada pela Convenção de Lomé de 1975, pela qual a Comunidade Econômica Europeia ofereceu vantagens no comércio com suas ex-colônias na África, Caribe e Pacífico, o relacionamento com o continente africano foi significativamente incrementado, com inúmeras trocas de visitas oficiais e assinaturas de acordos comerciais, culturais e de cooperação técnico-científica. Além da África, a diplomacia de Geisel também aumentou a aproximação iniciada por Médici aos países árabes, tendo em vista a forte dependência brasileira das importações de petróleo. No 
entanto, a aproximação desta vez foi também política, abandonando a postura de não comprometimento anterior para uma de afirmação do apoio às posições árabes, com Azeredo da Silveira manifestando na ONU apoio à causa palestina e condenando o sionismo como uma forma de racismo.

Os mecanismos de cooperação com a região envolveram diversas trocas de visitas oficiais; a instalação de embaixadas e acordos diplomáticos; a criação de comissões mistas de cooperação econômica e a assinatura de instrumentos de intercâmbio comercial para exportação de produtos brasileiros em troca do fornecimento de petróleo. Foram acordados ainda contratos da Braspetro para exploração de petróleo na Argélia, Líbia, Egito e Iraque; e de empresas brasileiras como a Interbrás e o Consórcio Mendes Junior-Interbrás para realização de projetos de infraestrutura na região, como estradas de ferro, hotéis e habitações. Além disso, os países árabes passaram também a investir os seus petrodólares no Brasil, aplicando-os em projetos industriais, de extração mineral e de produção agrícola.

As relações também foram incrementadas com os países socialistas, com o recebimento de ajuda técnica da URSS para projetos da CESP e acordos para importação de petróleo soviético em troca da exportação de manufaturados brasileiros. Nesse sentido, cabe destacar o restabelecimento de relações diplomáticas com a República Popular da China em 1974, apesar da forte oposição interna de alguns grupos militares, com o envio de uma missão da Associação de Exportadores Brasileiros junto a representantes do MRE e do Ministério do Planejamento ao país.

Para além dos interesses comerciais, Visentini (1998, p. 257) aponta que a aproximação à China estava relacionada ainda aos interesses em comum dos dois países junto ao Terceiro Mundo e em oposição ao Primeiro Mundo, com ambas as nações tendo se recusado a assinar o TNP e o apoio chinês ao Brasil nas questões do meio ambiente, do mar territorial brasileiro e de contestação à estrutura desigual da economia mundial. Também foram assinados acordos de cooperação econômica bilateral, prevendo a importação de petróleo, carvão mineral e siderúrgico, e insumos farmacêuticos, em troca da venda de manufaturados, soja e minério de ferro.

$\mathrm{Na}$ América Latina, os esforços de aproximação continuaram pautados por interesses de complementaridade econômica e cooperação técnica, além da estratégia de fortalecimento do Terceiro Mundo perante os países desenvolvidos. Acordou-se assim com a Argentina uma solução para o contencioso das hidrelétricas da Bacia do Prata, juntando-se ainda aos seus vizinhos para lançar a Iniciativa Amazônica em reação aos 
rumores de internacionalização da região, por meio da sua exploração conjunta e reafirmação das soberanias nacionais envolvidas.

Portanto, o "Pragmatismo Responsável” de Geisel rompeu com os elementos de fundo político e ideológico que restringiam o espaço de autonomia da política externa brasileira, entendida como um instrumento do "desenvolvimento", nos governos de Costa e Silva e Médici. O país passou a atuar de modo flexível e pragmático conforme a configuração de possibilidades abertas aos interesses nacionais, denotando um amadurecimento da política externa para adaptar-se à nova realidade do país de semiperiferia subdesenvolvida e industrializada, e atuar de modo mais eficiente em prol do seu desenvolvimento.

Em suma, as principais ações e instrumentos da política externa desses três governos foram:

- "Diplomacia da Prosperidade" (Costa e Silva e José Magalhães Pinto):

- afirmação dos interesses nacionais livre de ideologias;

- recuperação do universalismo e do eixo Norte-Sul no lugar do Leste-Oeste;

- três focos da política externa:

- reforma do comércio internacional e ampliação dos mercados de exportação;

- aquisição de tecnologias visando à autonomia econômica;

- estímulo a fluxos de capitais com melhores condições de prazo e pagamento.

- aliança com o Terceiro Mundo pela reforma do sistema econômico internacional: participação na formação do G77 e crítica à atuação do GATT.

- substituição do pan-americanismo pelo latino-americanismo: priorização da CECLA como foro de discussão regional no lugar da OEA e proposta de criação do Mercado Comum Latino-Americano.

- crescentes divergências com os Estados Unidos, apesar do discurso de cooperação:

- oposição às propostas de uma Força Interamericana de Paz e de internacionalização da Amazônia;

- crítica à Aliança para o Progresso;

- recusa a assinar o Tratado de Não-Proliferação Nuclear;

- contenciosos pela exportação de semimanufaturas e manufaturas brasileiras.

- aproximação bilateral dos países latino-americanos:

- acordos com a Argentina, Uruguai, Paraguai, Bolívia, Peru, Chile e México; 
- assinatura da Carta da Bacia do Prata (projeto de integração da Bacia do Prata).

- aproximação econômica com a URSS e o Leste Europeu;

- aproximação técnica, cientifica e econômica da Europa Ocidental: destaque para os empréstimos da Alemanha Federal para a indústria manufatureira, a Companhia Vale do Rio Doce e a Usina Hidrelétrica de Ilha Solteira;

- primeiro acordo comercial com a Índia em 1968;

- aproximação do Oriente Médio: acordos para compra de petróleo e venda de produtos brasileiros.

- "Diplomacia do Interesse Nacional” (Médici e Gibson Barboza):

- projeto de "Brasil potência", país de destaque membro do Primeiro Mundo;

- "política externa brasileira" (PEB): os princípios da igualdade soberana das nações, pacifismo, não intervenção e autodeterminação dos povos;

- "política internacional do Brasil" (PIB): atuação pautada pelo cálculo racional dos custos e benefícios, independente de ideologias e subordinando os princípios da PEB;

- relacionamento amistoso com os EUA, porém sem subordinar os interesses nacionais:

- repúdio ao Tratado de Não-Proliferação;

- ampliação do mar territorial brasileiro, com oposição de Washington;

- contenciosos pelas exportações brasileiras de têxteis, café solúvel e calçados;

- apoio aos golpes de Estado no Chile, Uruguai e Bolívia;

- acordos de cooperação e trocas de visitas de autoridades e oficiais do governo.

- não reconhecimento do Terceiro Mundo, atuando de forma independente pela reforma da Carta das Nações Unidas e da estrutura de poder mundial.

- afastamento da atuação conjunta com a América Latina, priorizando o relacionamento bilateral: acordos com a Bolívia (gás), Colômbia (carvão), Paraguai (Tratado de Itaipu) e Argentina;

- aproximação bilateral dos países desenvolvidos (acordos e financiamentos); - aproximação estritamente técnica e econômica dos países socialistas europeus;

- aproximação com Portugal, porém evitando envolvimento na questão do colonialismo:

- convenção sobre igualdade de direitos entre brasileiros e portugueses;

- cancelamento de manobras navais conjuntas no Atlântico Sul; 
- exclusão das colônias portuguesas da visita de Barboza à África em 1972;

- voto junto aos países colonialistas na ONU, e abstenção na condenação do

colonialismo, da apartheid e da discriminação racial.

- aproximação bilateral com os países africanos:

- visita de Barboza em 1972 a nove países africanos;

- trocas de visitas; acordos e estudos para a cooperação no Atlântico Sul;

- criação do Museu Afro-Brasileiro e de um Programa de Cooperação Cultural;

- estabelecimento de relações diplomáticas com Guiné, Serra Leoa e Gabão.

- aproximação equidistante entre Israel e os países árabes: acordos com o Iraque

para compra de petróleo e venda de manufaturados, e exploração de petróleo pela Petrobras no Egito, Líbia e Kuwait.

- "Pragmatismo Responsável" (Geisel e Azeredo da Silveira):

- flexibilidade e pragmatismo na busca do interesse nacional, sem ideologias;

- "não-alinhamento automático" aos Estados Unidos:

- Acordo Nuclear com a Alemanha Ocidental em 1975, oposto pelos EUA;

- rompimento do Acordo Militar Brasil-EUA em 1977;

- recusa a apoiar as intervenções na América Central pelos Estados Unidos,

- recusa a apoiar a proposta de segurança no Atlântico Sul;

- contenciosos sobre as exportações de manufaturados brasileiros para os EUA.

- atuação nos fóruns multilaterais junto ao Terceiro Mundo em defesa dos interesses dos países em desenvolvimento e da reforma da estrutura de poder político e econômico;

- avanços na aproximação à África: defesa da descolonização na ONU e reconhecimento da independência de Angola e Guiné-Bissau.

- defesa da retirada de Israel dos territórios palestinos, apoio à causa palestina e condenação do sionismo como uma forma de racismo na ONU;

- avanços na aproximação aos países árabes:

- inúmeros acordos para venda de produtos brasileiros e compra de petróleo;

- contratos da Braspetro para exploração de petróleo, e da Interbrás e do Consórcio Mendes Junior-Interbrás para realização de projetos de infraestrutura;

- investimentos árabes em projetos industriais, de extração mineral e de produção agrícola no Brasil.

- avanços na aproximação dos países socialistas: 
- acordo de ajuda técnica da URSS para projetos da CESP;

- acordos para compra de petróleo da URSS em troca de manufaturados;

- medidas de intensificação do comércio com o Leste Europeu.

- restabelecimento de relações diplomáticas com a China continental em 1974, com acordos para compra de petróleo e carvão mineral siderúrgico, em troca da exportação de manufaturados, soja e minério de ferro.

- avanços na aproximação com os países da América Latina, com destaque para a Iniciativa Amazônica (aliança com os países da região amazônica para exploração conjunta e reafirmação das soberanias nacionais).

\subsubsection{Comparação e resultados}

A análise dos instrumentos de política econômica e política externa de inserção internacional da economia brasileira ao longo desses três governos permite identificar que, de certa forma, a cada momento o Estado brasileiro respondeu de uma maneira particular aos desafios colocados pelas transformações da conjuntura externa e pelas necessidades da economia nacional, adaptando seus instrumentos de atuação às condições existentes para possibilitar a continuidade do crescimento econômico do país.

Em específico, cabe destacar a guinada de rumos promovida pelo governo Geisel que, apesar de manter o foco no crescimento econômico, tornou a autossuficiência energética e de bens de capital um objetivo a ser atingido pelo Estado brasileiro, diante da séria vulnerabilidade externa adquirida pela economia brasileira durante os governos anteriores, referente à importação de insumos industriais e capitais externos, e que se manifestou de modo violento com a crise do petróleo internacional. Foi quando a PIIEB finalmente firmou-se como uma política em prol da emancipação externa da economia brasileira, visando à libertação do processo produtivo de seus elos de dependência do exterior e a ampliação do espaço de autonomia brasileiro para a afirmação de seus interesses nacionais no mundo, embora tenha reforçado a dependência financeira do país do capital internacional.

Os dois eixos da PIIEB empreendida por esses três governos não podem ser entendidos sem abordar o movimento por maior abertura internacional da economia brasileira e a sua nova condição de subdesenvolvimento industrializado, em que um 
novo tipo de inserção internacional foi se configurando na condição intermediária de semiperiferia exportadora de manufaturados. Desse modo, os instrumentos dos dois eixos da PIIEB tiveram de enfrentar as dificuldades decorrentes dessa nova condição, de horizontes ampliados pelas novas possibilidades decorrentes sua estrutura produtiva industrializada, porém ainda dependente de capitais estrangeiros e acometida por sérias desigualdades socioeconômicas. Ou seja, apesar da ampliação do seu espaço de atuação internacional, o país permaneceu carente de recursos de poder para romper de modo definitivo com a sua dependência dos centros de dinamismo da economia-mundo capitalista, empreendendo um difícil movimento de distanciamento de sua tradicional subordinação ao poderio norte-americano e substituindo-a por uma diversificação de suas relações internacionais.

Em nossa visão, esta configuração conjuntural encontra semelhanças com o período Quadros e Goulart, quando as tentativas de conduzir os interesses brasileiros no cenário internacional de modo mais autônomo e independente de alinhamentos foram obstadas de modo crucial pelas pressões de Washington e pelas contradições do modelo de desenvolvimento associado. No entanto, apesar dessas similaridades, as significativas transformações dos cenários interno e externo ao país trouxeram outros limites e possibilidades para os governos de Costa e Silva, Médici e Geisel: além de garantirem a execução de suas políticas por meio de um regime autoritário, também encontraram maior espaço e flexibilidade no cenário internacional para atuar com mais autonomia, beneficiados pela multipolarização da economia-mundo capitalista e pelo declínio da hegemonia norte-americana. No governo Geisel em particular, o cenário internacional foi caracterizado também por uma séria crise internacional, que evidenciou a necessidade urgente de sanar os elementos de fragilidade externa e promover um grande esforço em prol da autossuficiência brasileira de insumos industriais e bens de capital.

Do lado da política econômica, os três governos continuaram o modelo de desenvolvimento associado, pautado pelo tripé entre capital privado nacional e capital estrangeiro sob a condução estratégica do Estado, com intensa programação de investimentos, realocação de recursos e medidas de incentivo a setores identificados como prioritários. Entretanto, cabe destacar o novo viés "voltado para o exterior" empreendido por Costa e Silva e Médici em direção a uma crescente abertura econômica pela ampliação das exportações de primários e manufaturados leves, o que 
produziu como contrapartida uma séria vulnerabilidade a fatores externos decorrente das importações necessárias de insumos industriais e bens de capital.

Impulsionado pela crise internacional do petróleo, que evidenciou a insustentabilidade desse "modelo", o governo Geisel promoveu uma verdadeira mudança de rumos ao buscar a autossuficiência da economia brasileira em termos de insumos industriais e bens de capital. Além de reduzir com relativo sucesso a dependência externa da importação desses produtos, instalando novos setores industriais e promovendo a diversificação das fontes de energia nacional, o Estado conseguiu também sustentar um ciclo de crescimento econômico em meio à crise econômica internacional dos anos 1970, incorrendo, entretanto, em um forte endividamento cujas consequências foram duramente vividas pelo país nos anos 1980 .

Cabe destacar ainda que os governos de Costa e Silva e Médici buscaram fomentar o sistema de financiamento brasileiro para incentivar o mercado consumidor interno e a produção nacional de bens de consumo, tendo iniciado ainda uma política de modernização e fortalecimento do empresariado nacional. Essa política foi desenvolvida pelo governo Geisel por meio do novo perfil conferido ao BNDE pelo II PND, voltado para o fortalecimento do capital privado nacional por meio de uma nova gama de mecanismos de financiamento e alavancagem de recursos.

Se o crescimento econômico foi mantido com sucesso nesse período, este baseou-se no estímulo ao consumo das classes mais abastadas e às exportações de bens de consumo não duráveis, tornados possíveis por crescentes importações de insumos industriais e bens de capital, além do progressivo comprometimento financeiro externo. Tratou-se, portanto, de um movimento de abertura econômica externa, que foi inevitavelmente acompanhado pelo aumento da vulnerabilidade externa da economia brasileira, como ficou evidenciado nos anos 1970 com o choque do petróleo. Mesmo a correção de rumos empreendida por Geisel, embora tenha contribuído significativamente para superar a dependência de insumos industriais e bens de capital estrangeiros, deu-se a partir da intensificação do recurso ao capital estrangeiro, acabando por redefinir o problema da dependência externa para a adversidade do financiamento da dívida externa nos anos 1980.

Do lado da política externa, os três governos desenvolveram abordagens diferentes de como a política externa deveria atuar em prol dos interesses nacionais e diante das condicionantes externas existentes. Enquanto as políticas externas de Costa e Silva e Médici caracterizaram-se por situar cada uma o país em uma ponta do eixo 
Norte-Sul - o primeiro junto ao Terceiro Mundo, e o segundo junto ao Primeiro Mundo -, a de Geisel posicionou o país de modo flexível e pragmático, buscando atuar com maior autonomia em busca dos interesses nacionais, de modo independente de alinhamentos e ideologias.

Essas diferenças de abordagem se deram principalmente em três âmbitos: no alinhamento às posições do "mundo ocidental capitalista" e dos Estados Unidos, na atuação conjunta com o Terceiro Mundo em prol dos interesses dos países subdesenvolvidos, e na ampliação do espaço de autonomia brasileiro livre de alinhamentos políticos ou ideológicos.

Costa e Silva iniciou um movimento de afastamento dos Estados Unidos com paralela aproximação do Terceiro Mundo, refletindo a necessidade de ampliar as exportações e as fontes de financiamento para sustentar o crescimento econômico nacional, porém sem produzir um rompimento definitivo com os entraves políticos e ideológicos que obstavam uma atuação mais autônoma de sua política externa.

Embora Médici tenha orientado sua política externa por um cálculo racional de custos e benefícios que priorizou o relacionamento bilateral caso a caso, o discurso do alinhamento ocidental foi retomado, recusando o grupo do Terceiro Mundo e empreendendo ações em conformidade com a defesa do "mundo ocidental" no cenário internacional. Mesmo assim, sua política externa empreendeu importantes movimentos de diversificação das relações exteriores, tendo em vista a crescente dependência das receitas de exportação e das importações de capital produtivo e financeiro.

Já a política externa de Geisel posicionou-se de modo declaradamente contrário aos alinhamentos, elegendo uma postura mais autônoma e flexível para perseguir os interesses nacionais. De certo modo, o desafio de manter o crescimento econômico e promover a autossuficiência de insumos industriais e bens de capital em meio à crise internacional do petróleo exigia uma atuação internacional mais pragmática em prol dos interesses nacionais, constituindo-se no impulso que faltava para produzir um quase rompimento com a tradição diplomática dos últimos governos.

Assim, o relacionamento com os Estados Unidos tornou-se mais complexo e conflituoso, e questões sensíveis passaram a ser abordadas de modo mais objetivo e livre de vínculos político-ideológicos. O país aproximou-se dos países árabes, latinoamericanos, africanos e asiáticos, passou a defender abertamente a descolonização e a causa palestina, e restabeleceu relações com a República Popular da China. 
Portanto, os dois eixos da PIIEB trabalharam de modos diversos ao longo desses três governos, como reflexo das condicionantes externas enfrentadas e das exigências do processo de crescimento econômico nacional. Entretanto, foi somente no governo Geisel que produziu-se uma quase ruptura com as tendências empreendidas pelos governos anteriores, com a política econômica logrando avançar na autonomização do processo produtivo brasileiro de insumos industriais e bens de capital do exterior, ainda que com a contrapartida do agravamento da vulnerabilidade financeira externa; e a política externa promovendo a ampliação das parcerias internacionais do país, entendida como uma forma de diluir sua dependência do exterior, alargar as perspectivas da economia brasileira e aproveitar as oportunidades do cenário internacional para exercer maior autonomia na perseguição de seus interesses.

\section{CAPÍTULO 3}

REVISITANDO A "AUTONOMIA NA DEPENDÊNCIA" 
Tendo em vista as questões abordadas no capítulo anterior, busca-se aqui fornecer uma síntese das formas de interação desenvolvidas entre os instrumentos dos dois eixos da PIIEB, o da política econômica e o da política externa, além de indicar suas implicações para a alteração do padrão de inserção internacional da economia brasileira. Objetiva-se, ainda,ilustrar a análise com os dados estatísticos do período, que evidenciam de modo empírico as transformações ocorridas na estrutura econômica brasileira - sem, no entanto, pretensões de estabelecer relações de causalidade entre os elementos estudados e os indicadores econômicos a serem apresentados. Com estes fins, o texto encontra-se dividido em duas seções, em que a primeira destina-se à síntese das formas de interação desenvolvidas entre os instrumentos dos dois eixos da PIIEB e suas implicações, e a segunda ilustra a evolução da economia brasileira por meio dos dados estatísticos do período.

Adicionalmente, em paralelo e de forma complementar aos objetivos descritos, pretende-se analisar como o conceito de "autonomia na dependência" cunhado por Moura (1980) pode ser aplicado para caracterizar também o período estudado, por meio da aquisição de novas nuances interpretativas conforme tanto o papel do Estado quanto o das transformações da economia-mundo capitalista foram se alterando a cada momento, definindo novos instrumentos de ação e condições sistêmicas para a redefinição dos termos da autonomia e dependência da economia brasileira.

\subsection{SÍNTESE DOS INSTRUMENTOS DOS DOIS EIXOS DA PIIEB: FORMAS DE INTERAÇÃO E IMPLICAÇÕES}

Os instrumentos da PIIEB desempenharam um peso e papel fundamentais para as significativas transformações da estrutura produtiva brasileira no período de 1945 a 1980, trabalhando ao lado das forças sistêmicas da economia-mundo capitalista e a partir das condicionantes nacionais para produzir uma alteração do padrão de inserção internacional da economia brasileira. Embora sua eficiência ao longo do período tenha sido comprometida por eventuais descompassos entre os instrumentos de seus dois eixos de atuação, nem sempre complementares, e pela sua própria trajetória, que não foi 
de todo coerente nem homogênea, no geral pode-se dizer que a PIIEB contribuiu de modo crucial para a redefinição dos termos da dependência brasileira e para a transformação estrutural de sua economia.

Destarte, de economia reflexa que atuava como periferia exportadora de primários a economia diversificada e relativamente dinâmica da semiperiferia industrializada, o Brasil foi estruturando condições para controlar e sustentar seus próprios ciclos de acumulação de capital, permitindo uma revisão de sua trajetória tradicionalmente acoplada às oscilações da economia mundial. Ainda que não tenha conseguido uma emancipação mais significativa da dinâmica do sistema internacional, a economia brasileira formou e consolidou uma nova inserção internacional, em que um espaço maior de autonomia foi conquistado tanto em termos de estrutura produtiva quanto de atuação no cenário internacional em prol dos interesses nacionais, embora tal processo tenha sido acompanhado de uma crescente vulnerabilidade ao capital financeiro internacional.

$\mathrm{Na}$ realidade, esse movimento remonta ao período de turbulência dos anos 1930 à Segunda Guerra Mundial, quando se conseguiu instalar um parque industrial voltado ao consumo interno sobre condições de forte restrição externa. Nesse período, o papel do Estado foi essencial para impulsionar a transformação da estrutura produtiva brasileira em direção a uma maior autonomia da economia nacional, ao mesmo tempo em que redefinia o seu grau de dependência e subordinação à economia internacional, de tal forma que Moura (1980) caracterizou a política governamental do primeiro governo Vargas como uma de "autonomia na dependência".

Nesse sentido, a PIIEB que caracterizou o período estudado de 1945 a 1980 revisou, em diferentes graus, esse conceito da "autonomia na dependência" de Moura (1980), na medida em que seus instrumentos de ação constituíram um movimento geral de redefinição dos termos da dependência externa brasileira por meio da sua transformação estrutural e da alteração de seu espaço de atuação internacional. Sem perder de vista que, tanto no caso do período estudado por Moura (1980) quanto no do intervalo objeto desta pesquisa, a formulação e alcance do primeiro governo Vargas e da PIIEB foram moderadas pelas transformações da economia-mundo capitalista, que foi conferindo maior ou menor espaço para a redefinição dos termos da autonomia e da dependência externa da economia brasileira.

O sentido geral dos dois eixos da PIIEB, cujos instrumentos de atuação foram abordados de modo mais detalhado no capítulo anterior, foi pincelado de modo 
indicativo no quadro a seguir, assim como a forma de interação entre eles, e as implicações dessa interação em termos de uma alteração do padrão de inserção internacional da economia brasileira. Desse modo, pretende-se contribuir para a análise de como a PIIEB, através da síntese dos instrumentos de seus dois eixos, foi capaz de influir sobre o padrão de inserção internacional da economia brasileira, ou de criar condições para a sua alteração, tendo em vista o peso das forças sistêmicas da economia-mundo capitalista. 


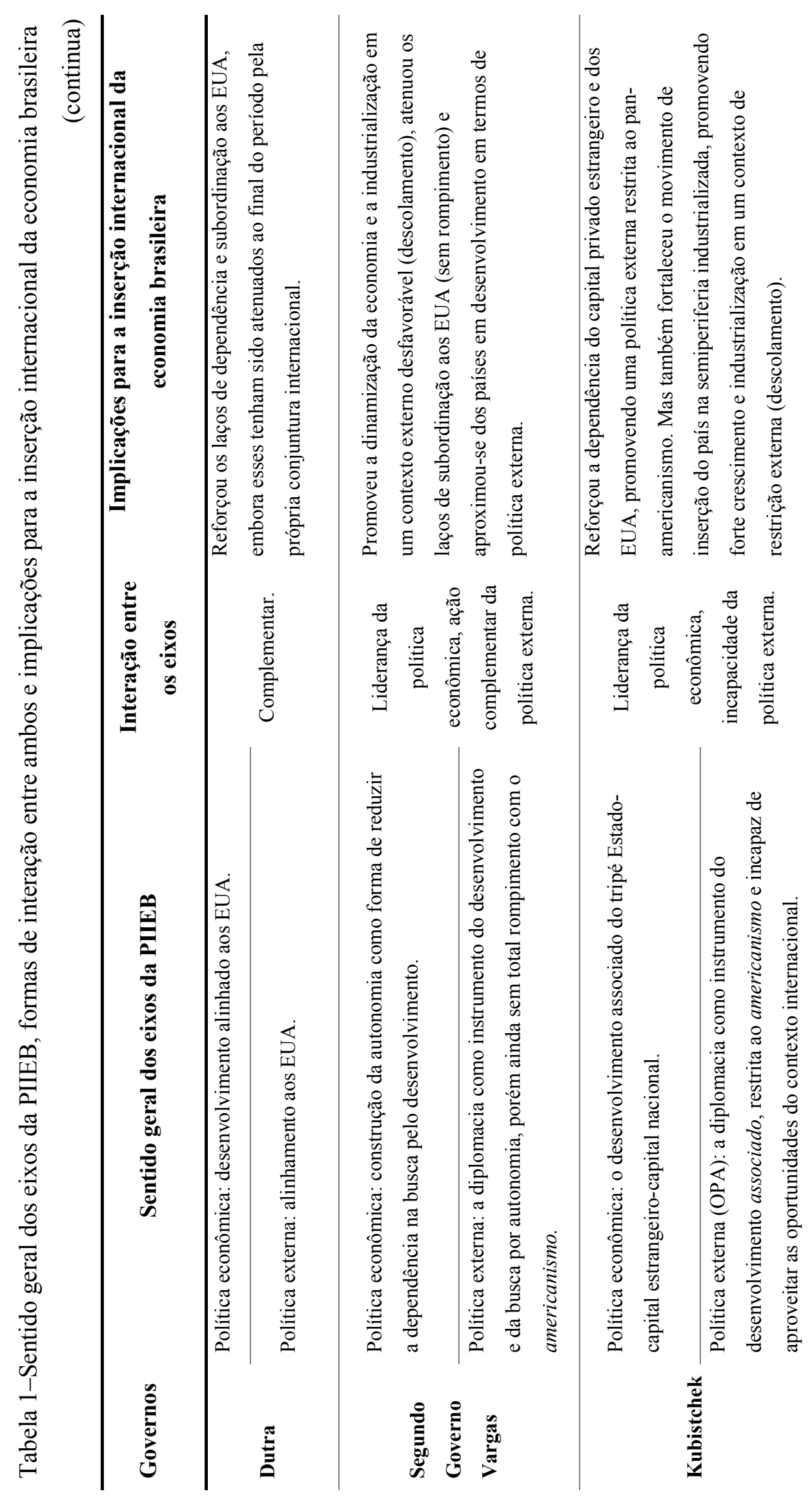

品 


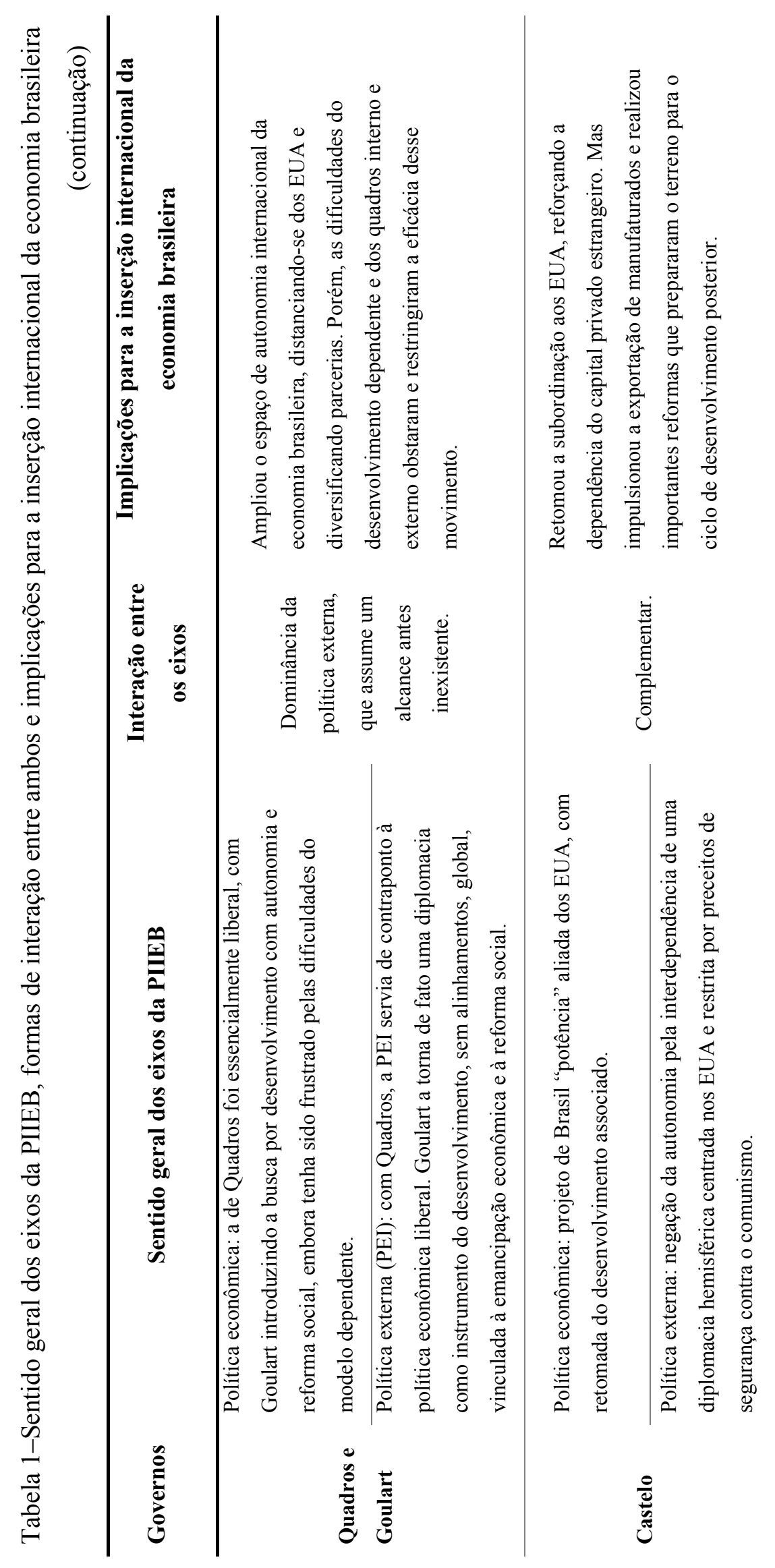




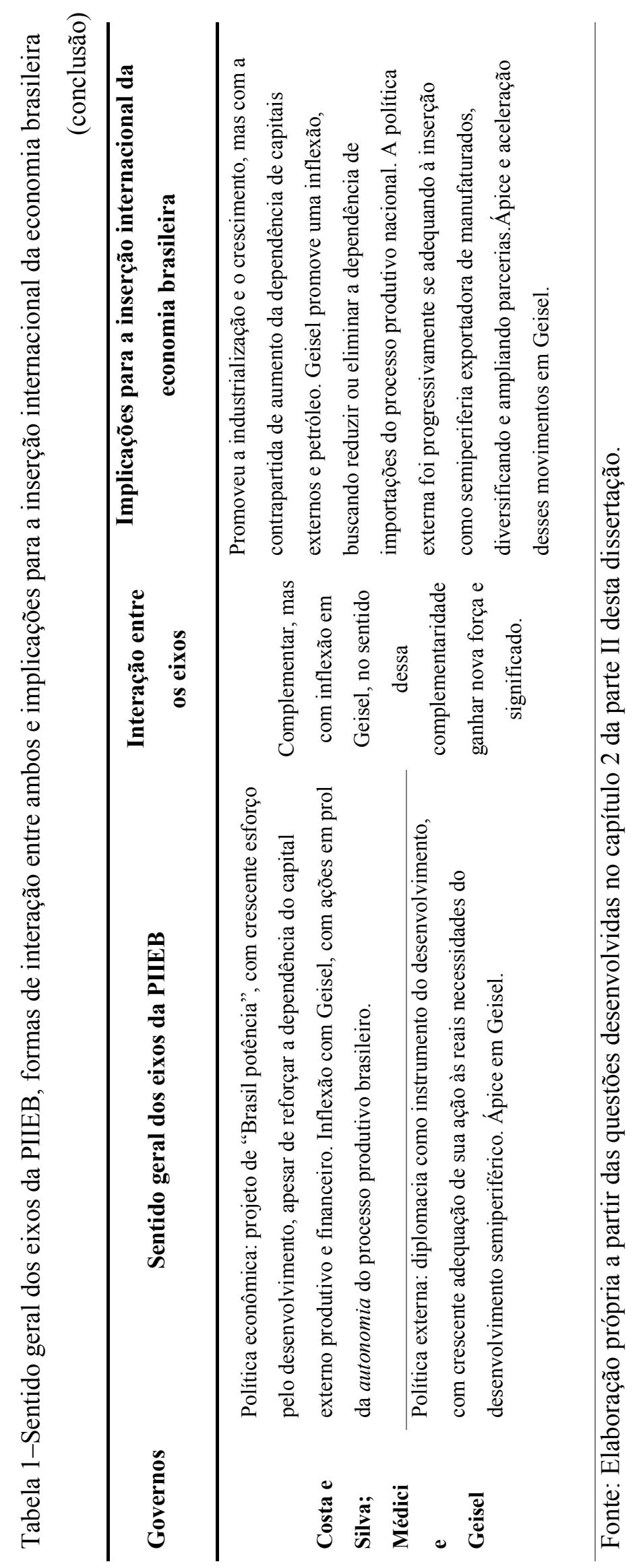

ํㅜ 
Tal sistematização, apesar da sua generalidade, procura evidenciar o sentido predominante dos instrumentos dos dois eixos da PIIEB, a forma de interação desenvolvida entre eles, e as sua atuação para a alteração do padrão de inserção internacional da economia brasileira. É interessante notar que a atuação conjunta dos instrumentos dos dois eixos da PIIEB transitou ao longo do período estudado como um pêndulo oscilando entre os dois termos da "autonomia na dependência", sem nunca chegar a tocar um dos extremos - nem a completa autonomia nem a total dependência. $\mathrm{Na}$ realidade, diversas posições entre os dois extremos foram sinalizadas ao longo do período, ora pendendo mais para um lado ora para outro e em graus diferentes, de tal modo que o significado do binômio "autonomia na dependência" foi admitindo novas interpretações.

Entretanto, a despeito dessas oscilações, o movimento geral foi em direção ao ganho de autonomia com redefinição dos termos da dependência exterior, com o final dos anos 1970 deparando-se com uma economia mais capaz de controlar e promover a sua própria dinâmica produtiva e acumulação de capital em relação ao seu estado do imediato pós-Segunda Guerra Mundial, embora tenha mantido e até intensificado alguns aspectos de seu estado de subdesenvolvimento e vulnerabilidade a elementos do exterior.

No governo Dutra, tanto os instrumentos do eixo da política econômica, quanto do da política externa, agiram de modo complementar para reforçar os laços de subordinação da economia brasileira aos Estados Unidos. Do lado econômico esse movimento expressou-se por um projeto de desenvolvimento alinhado aos interesses norte-americanos, em que se buscou uma inserção privilegiada na nova ordem internacional sob a liderança de Washington, favorável à participação do capital privado estrangeiro e voltada a solucionar os "gargalos" da infraestrutura produtiva que obstavam a dinâmica do capitalismo. Do lado diplomático, tais pretensões foram reforçadas pela predominância do americanismo, apesar da ocorrência de alguns sinais de escape não intencionais a essa orientação geral, como evidenciado pelo episódio do "Decálogo de Montevidéu” na Cepal.

Embora o sentido geral tenha sido de reforço da dependência e subordinação aos Estados Unidos,nesse período começaram a ser formados, de modo não intencional, canais de condução a uma futura reversão desse movimento, como a identificação do Estado como condutor estratégico do desenvolvimento e alguns tímidos ensaios de contestação à realidade das relações centro-periferia. 
Com o segundo governo Vargas, essa reversão se afirmou com a retomada de um projeto de desenvolvimento e de uma programação de investimentos pelo Estado.Aqui, a atuação dos instrumentos dos dois eixos da PIIEB também foi complementar, mas com uma relativa liderança da política econômica em decorrência de tensões diretamente sofridas pela política externa que limitaram um distanciamento mais efetivo da potência norte-americana. Assim, o eixo da política econômica atuou para uma inserção internacional diferente da economia brasileira na medida em que impulsionou a sua dinamização e industrialização em contexto de restrição cambial e escassos financiamentos externos, por meio do fortalecimento técnico e institucional do Estado na programação de investimentos e sem subordinar os interesses nacionais aos do capital estrangeiro. Já os instrumentos da política externa, apesar de afastarem-se da vinculação norte-americana por meio da aproximação do mundo em desenvolvimento, também restringiram a busca por autonomia pela aliança militar com os Estados Unidos, denotando a insuficiência de seus recursos de poder para promover uma efetiva emancipação da tradicional influência de Washington.

Embora Kubistchek tenha avançado no processo de fortalecimento da dinâmica de acumulação nacional, seu governo no geral retomou a aproximação aos Estados Unidos, que se expressou pelo lado do eixo da política econômica no modelo de desenvolvimento associado ao capital estrangeiro, e pelo lado do eixo da política externa pelo foco hemisférico nas relações exteriores da Operação Pan-Americana.

Desse modo, houve uma relativa liderança dos instrumentos do eixo da política econômica ao impulsionar um ciclo de dinamismo e desenvolvimento sob a condução do Estado em um contexto de séria restrição externa, fortalecendo o movimento em direção à nova inserção do país como semiperiferia industrializada, ainda que com seus laços de dependência com o capital privado estrangeiro reforçados. Os instrumentos da política externa, apesar de afirmarem-na como instrumento do desenvolvimento, foram incapazes de aproveitar a nova condição semiperiférica da economia brasileira no contexto de formação do Terceiro Mundo e contestação da realidade centro-periferia, restringindo o foco de sua atuação ao pan-americanismo subordinado aos Estados Unidos.

De certo modo, esses movimentos inverteram-se nos governos de Quadros e Goulart: enquanto a capacidade de atuação do eixo da política econômica viu-se tolhida pelas dificuldades decorrentes do modelo de desenvolvimento associado e expressas a partir dos problemas da política econômica tais como os da inflação e do balanço de 
pagamentos, o eixo da política externa mostrou habilidade para ampliar o espaço de autonomia da economia brasileira, buscando distanciar-se da dependência norteamericana e aproveitar as oportunidades decorrentes da posição semiperiférica do país e das transformações do quadro internacional. Em consequência, houve dominância dos instrumentos da política externa, acenando para o impulso de uma mudança da inserção internacional da economia brasileira em prol de seu desenvolvimento, a qual entretanto não se efetivou.

Paralelamente, os esforços da PIIEB de Quadros e Goulart foram decisivamente obstados pelas pressões de Washington e pelas contradições do modelo de desenvolvimento associado, especialmente a inflação, o desequilíbrio nas contas externas, a crescente dependência do capital estrangeiro e a instabilidade política e social que dificultava a consecução das ações empreendidas pelo governo. Mais uma vez evidenciava-se, desse modo, a insuficiência de capacidade e de recursos de poder da economia brasileira diante das condições do sistema internacional para atuar com maior autonomia em prol de seu desenvolvimento.

Com o golpe militar de 1964, o governo Castelo renegou a autonomia pela ideia da interdependência hemisférica sob a liderança dos Estados Unidos e retomou a opção do desenvolvimento associado e dependente em escala ampliada. Esse movimento foi produzido tanto pelo eixo da política econômica, quanto pelo da política externa, que atuaram de modo complementar para uma inserção internacional do país como economia industrializada vinculada ao mundo ocidental, com protagonismo regional e sob a liderança de Washington.

Apesar do estreitamento da vinculação aos Estados Unidos, ambos os eixos também trabalharam para impulsionar a venda de manufaturados para o exterior, diversificando as exportações brasileiras e seus parceiros comerciais, de modo a abrir uma nova perspectiva para o país nos mercados internacionais. Ademais, as importantes reformas estruturais promovidas por Castelo prepararam o terreno para o ciclo de dinamismo econômico posterior ao adequarem as instituições brasileiras às novas realidades de sua estrutura econômica crescentemente complexa e industrializada.

De certa forma, os governos de Costa e Silva e Médici iniciaram uma revisão dessas tendências,ainda que tímida e sem provocar um movimento mais decisivo de distanciamento do americanismo.No eixo da política externa, houve um gradual avanço da diversificação de parcerias econômicas em prol das necessidades do modelo de desenvolvimento nacional, embora seus esforços tenham sido moderados pelas 
dificuldades de se desvencilhar da influência norte-americana. Mesmo com a hegemonia de Washington em declínio frente ao surgimento de novas forças políticoeconômicas no cenário internacional, os instrumentos da política externa não foram capazes de produzir uma ruptura mais definitiva da subordinação aos Estados Unidos.

Já o eixo da política econômica,embora tenha promovido com relativo sucesso o fortalecimento do setor industrial de bens de consumo e a melhoria da infraestrutura de energia e transportes, teve a contrapartida do aumento das importações de insumos industriais e bens de capital, incorrendo em uma crescente dependência do capital estrangeiro, tanto produtivo quanto financeiro.

Nesse sentido, ambos os instrumentos do eixo da política econômica e da política externa, embora tenham promovido movimentos importantes de fortalecimento de alguns setores econômicos e de ampliação das parcerias econômicas internacionais, reforçaram alguns aspectos de dependência externa da economia brasileira e mostraramse incapazes de aproveitar todo o potencial decorrente das transformações sofridas pela economia-mundo capitalista, mantendo-se subordinado aos Estados Unidos.

Esta condição fica ainda mais evidente ao levarmos em conta a PIIEB do governo Geisel, quando tanto os instrumentos da política econômica quanto da política externa produziram quase uma ruptura das tendências anteriores, ao trabalharam ativamente pela redução da dependência de importações da economia brasileira em direção à autossuficiência energética e de insumos industriais, e assumirem uma postura livre de alinhamentos, atuando de modo flexível e pragmático nas arenas internacionais em prol dos interesses nacionais e afastando-se definitivamente da subordinação a Washington

Consequentemente, ambos os eixos da política econômica e da política externa trabalharam de modo complementar em prol da maior autonomia da economia brasileira, tanto no que diz respeito ao relativo descolamento da acumulação de capital nacional em relação à economia internacional, quanto no que tange à ampliação do espaço de setores de bens de capital e produtos de maior valor agregado no processo de desenvolvimento.Entretanto, não se pode deixar de lembrar que, a despeito do esforço da PIIEB de Geisel em conquistar esses objetivos, houve a contrapartida do aguçamento da dependência financeira do Estado brasileiro, que se expressou por meio de um crescente endividamento externo cujas consequências foram duramente vividas na década posterior. 


\subsection{ANÁLISE EMPÍRICA: A EVOLUÇÃO DOS DADOS ESTATÍSTICOS DO PERÍODO}

Em termos concretos, o exame dos dados estatísticos do período pode subsidiar a análise de como a interação entre os dois eixos da PIIEB produziu resultados para a mudança do padrão de inserção internacional da economia brasileira, ao ilustrar a sua evolução entre 1945 e 1980.

Iniciando pelo crescimento econômico, o gráfico 1 permite visualizar a expansão anual do PIB em termos reais, em que se destaca o forte crescimento ocorrido durante o Plano de Metas (1957 a 1961) e o Milagre Econômico (1968 a 1973). Apesar dos intervalos de desaceleração no inicio do governo Dutra, no interregno entre Vargas e Kubistchek e no governo Goulart, a média de crescimento econômico para o período foi significativa, oscilando em torno de $7 \%$ a.a. em termos reais.

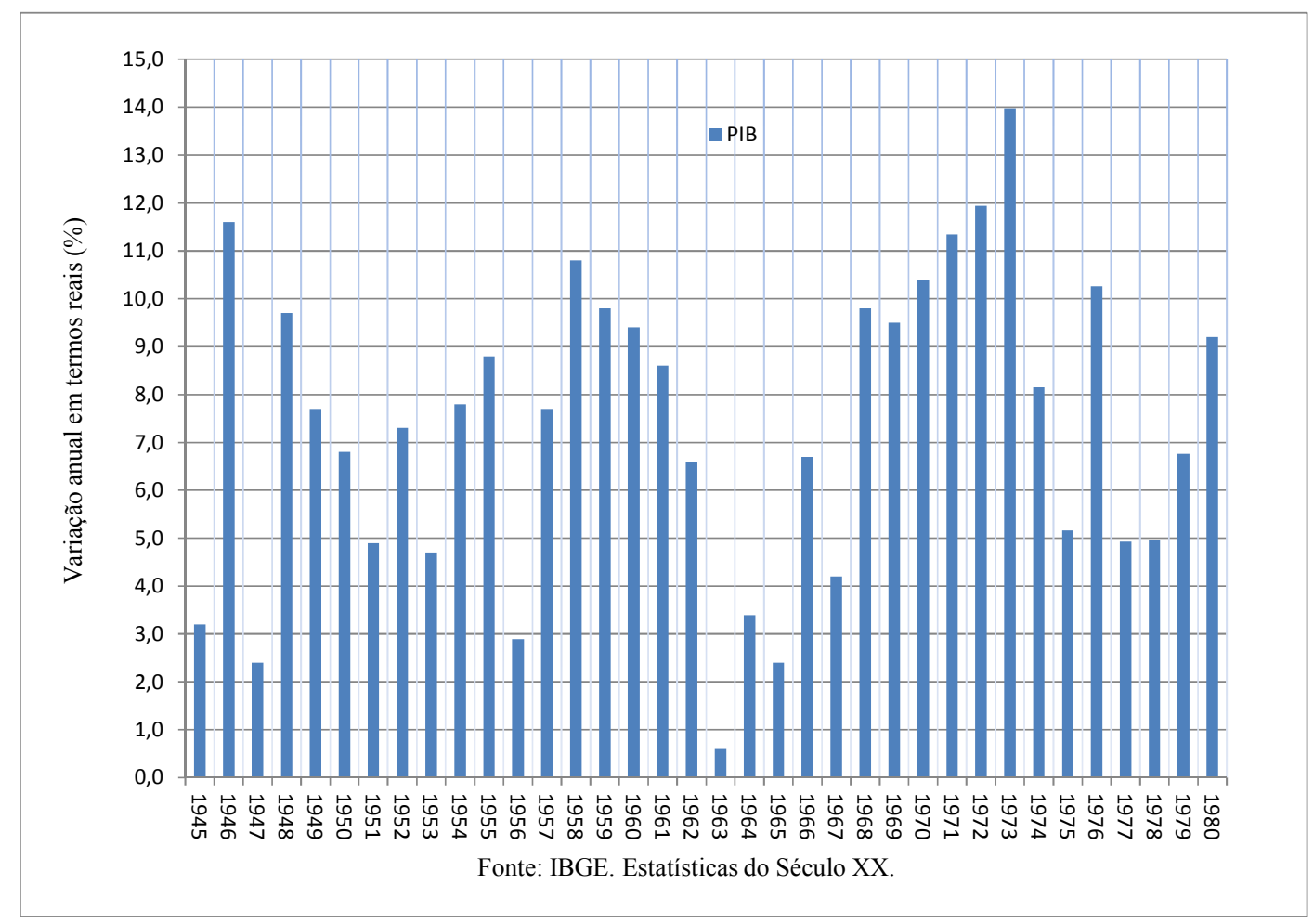

Gráfico 1 - Taxa anual de crescimento real do PIB brasileiro, \% a.a., 1945-1980 
Embora o componente mais significativo do PIB durante todo o período tenha sido o de consumo (média de $80 \%$ do $\mathrm{PIB}$ ), houve um considerável movimento de aumento da participação da formação bruta de capital, de nove pontos percentuais do PIB, chegando a $24 \%$ do PIB em 1980. Em contrapartida, apesar de permanecer majoritária, a participação do consumo foi reduzida (de $86 \%$ para $78 \%$ ), enquanto a do comércio exterior oscilou ao redor do zero, tendo uma participação negativa durante todos os anos 1970, sinalizando que as transformações da economia brasileira no período estiveram estreitamente relacionadas aos esforços de investimentos conduzidos pelo Estado, com significativos reflexos na acumulação de capital e na formação bruta de capital brasileira.

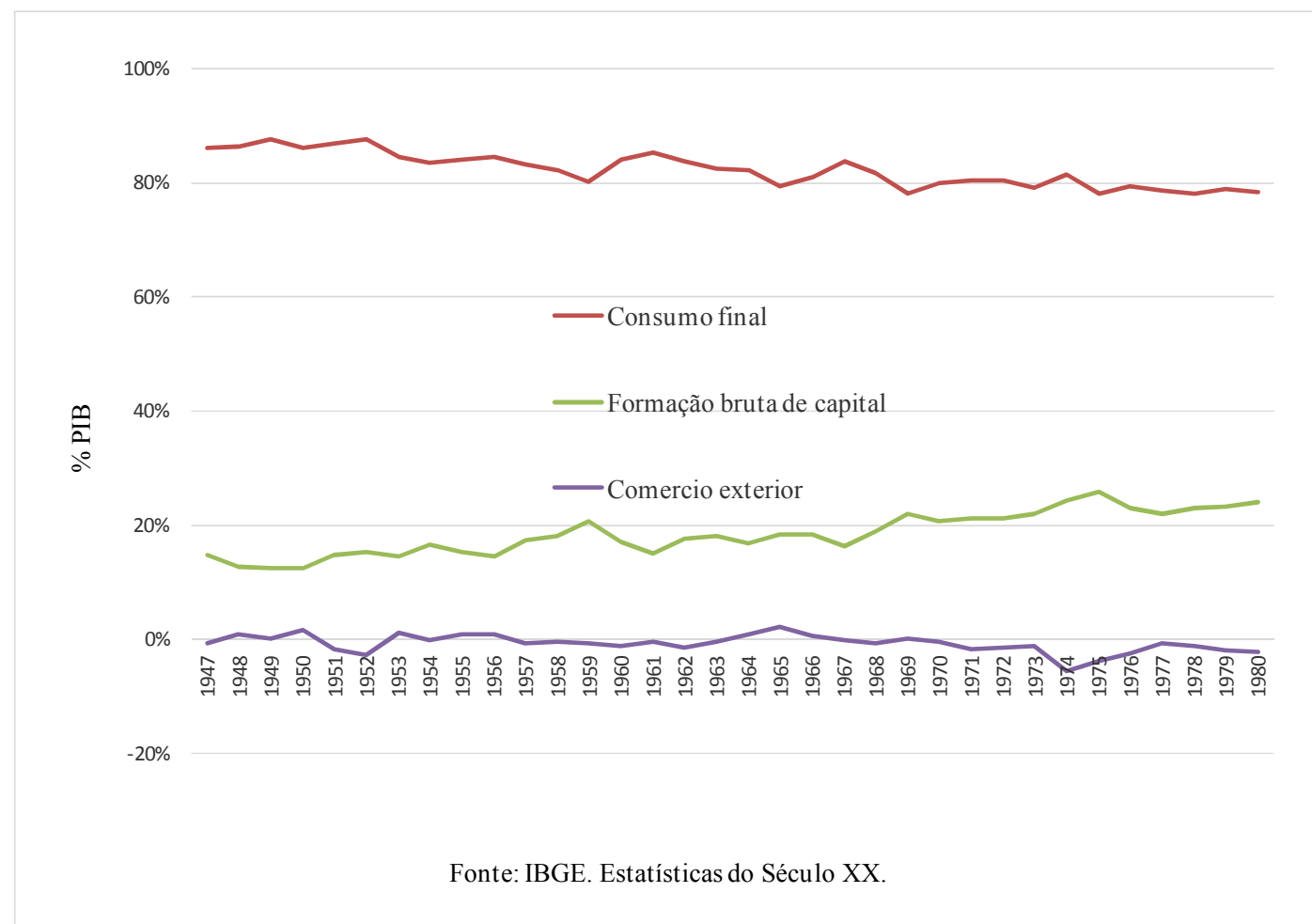

Gráfico 2 - Composição do PIB brasileiro, \% PIB, 1945-1980

Nesse sentido, o gráfico 3 evidencia a tendência geral de crescimento da formação bruta de capital fixo (FBCF) no período, permitindo visualizar também os ciclos de investimento promovidos pelo segundo governo Vargas (1951-54), pelo Plano de Metas (1956-61). No entanto, apesar desses esforços, foi a partir de 1968 que deu-se uma aceleração definitiva da FBCF de oito pontos percentuais do PIB, saltando do 
patamar dos $16 \%$ para $24 \%$ do PIB em 1980 - no caso da FBCF do governo federal, o salto foi de $1,9 \%$ para $4,7 \%$ do PIB no mesmo período.

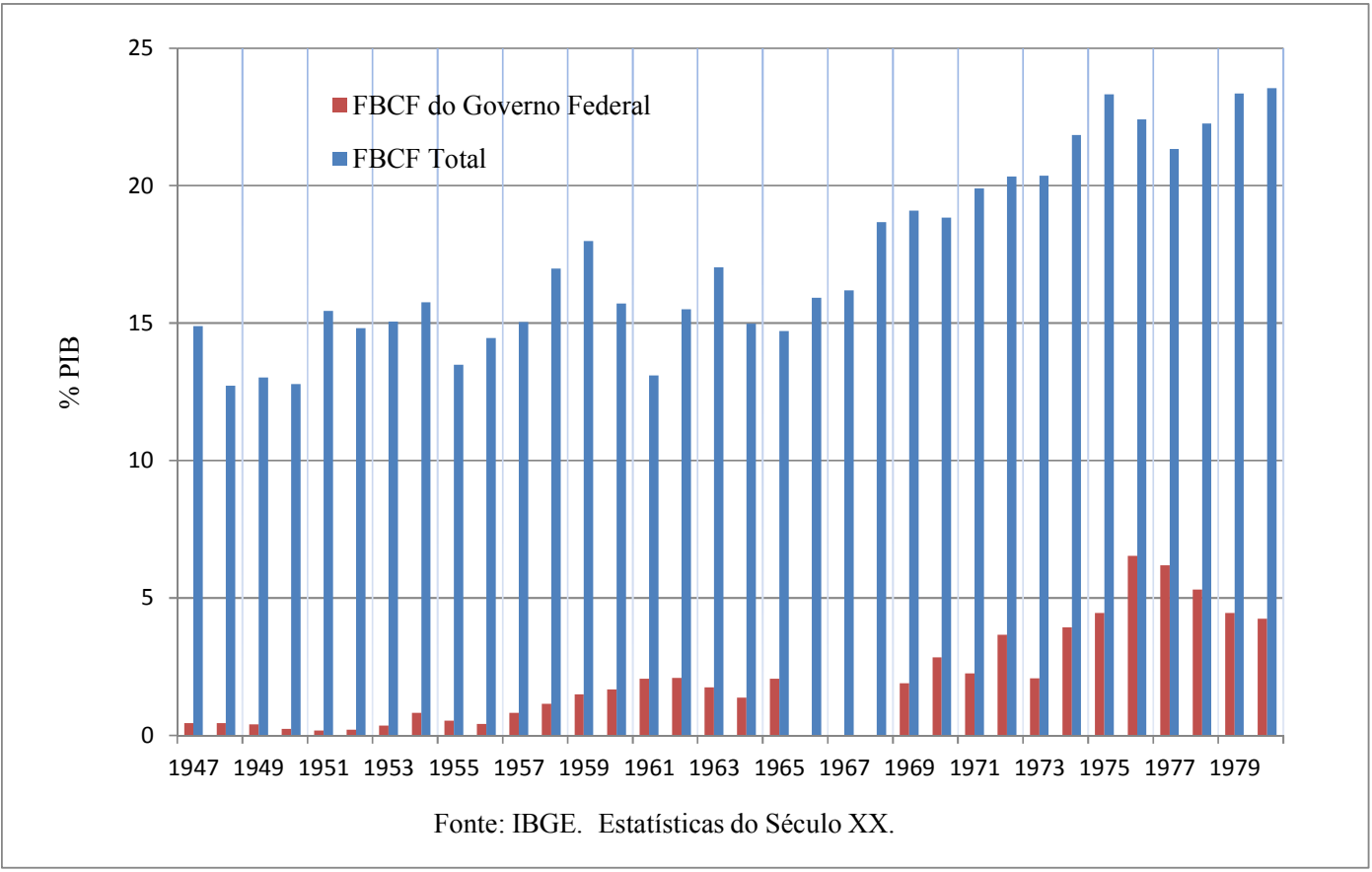

Gráfico 3 - Formação bruta de capital fixo total e do governo federal, \% PIB, $1945-1980$

Esse comportamento da FBCF coaduna com o movimento de aparelhamento e capacitação do Estado brasileiro como programador do desenvolvimento industrial, quando altos volumes de investimentos foram mobilizados para promover uma profunda transformação da estrutura produtiva brasileira, instalando a indústria pesada de insumos e equipamentos industriais, e expandindo a infraestrutura energética e de transportes do país. Esse movimento envolveu a criação de inúmeras empresas estatais e instituições governamentais que ampliaram a capacidade de intervenção, gerenciamento e coordenação das atividades econômicas pelo Estado.

A título de ilustração, a tabela 2 elenca algumas empresas estatais, institutos de pesquisa, conselhos e organizações criados pelo Estado brasileiro no período e que estiveram, de algum modo, relacionados aos programas de desenvolvimento econômico nacional. 
Tabela 2 - Instituições criadas pelo Estado brasileiro entre 1945 e 1980

\begin{tabular}{|c|c|c|}
\hline $\begin{array}{l}\text { Data de } \\
\text { Criação }\end{array}$ & Instituições & Governo \\
\hline 1946 & Serviço Social da Indústria (SESI) & Dutra \\
\hline 1946 & Serviço Social do Comércio (SESC) & Dutra \\
\hline 1948 & Companhia Hidroelétrica do São Francisco (CHESF) & Dutra \\
\hline 1948 & Escola Superior de Guerra (ESG) & Dutra \\
\hline 1951 & Banco Nacional de Credito Cooperativo (BNCC) & Vargas \\
\hline 1952 & Instituto Brasileiro do Café (IBC) & Vargas \\
\hline 1952 & Banco Nacional de Desenvolvimento Econômico (BNDE) & Vargas \\
\hline 1952 & Banco do Nordeste do Brasil (BNB) & Vargas \\
\hline 1953 & Petrobras & Vargas \\
\hline 1953 & Comissão Executiva do Plano do Carvão Nacional (CEPCAN) & Vargas \\
\hline 1953 & $\begin{array}{l}\text { Superintendência do Plano de Valorização Econômica da } \\
\text { Amazônia (futura SUDAM) }\end{array}$ & Vargas \\
\hline 1953 & Grupo Misto CEPAL-BNDE de Estratégia de Desenvolvimento & Vargas \\
\hline 1954 & Instituto Nacional de Imigração e Colonização (INIC) & Vargas \\
\hline 1956 & Conselho de Desenvolvimento e Grupos Executivos Setoriais & Kubistchek \\
\hline 1956 & Frigoríficos Nacionais S.A. (FRINASA) & Kubistchek \\
\hline 1958 & $\begin{array}{c}\text { Comissão Brasileira de Turismo (COMBRATUR) e Empresa } \\
\text { Brasileira de Turismo (EMBRATUR) }\end{array}$ & Kubistchek \\
\hline 1958 & Usinas Siderúrgicas de Minas Gerais (USIMINAS) & Kubistchek \\
\hline 1959 & Companhia Siderúrgica Paulista (COSIPA) & Kubistchek \\
\hline 1959 & Companhia Ferro e Aço de Vitória (Aço Vitória) & Kubistchek \\
\hline 1961 & $\begin{array}{l}\text { Conselho de Desenvolvimento da Pesca (CODEPE) e } \\
\text { Superintendência de Desenvolvimento da Pesca (SUDEPE) }\end{array}$ & Quadros \\
\hline 1961 & Centrais Elétricas Brasileiras S.A. (Eletrobrás) & Quadros \\
\hline 1964 & Banco Nacional de Habitação (BNH) & Castelo \\
\hline 1964 & $\begin{array}{l}\text { Banco Central do Brasil (BCB) e Conselho Monetário Nacional } \\
\text { (CMN) }\end{array}$ & Castelo \\
\hline 1966 & Fundo de Garantia por Tempo de Serviço (FGTS) & Castelo \\
\hline 1966 & Instituto Nacional de Previdência Social (INPS) & Castelo \\
\hline 1966 & Centrais Elétricas de São Paulo (CESP) & Castelo \\
\hline 1969 & Empresa Brasileira de Aeronáutica (Embraer) & Costa e Silva \\
\hline 1969 & Companhia de Pesquisa e Recursos Minerais (CPRM) & Costa e Silva \\
\hline 1970 & Instituto Nacional de Colonização e Reforma Agrária (INCRA) & Médici \\
\hline 1972 & Refinaria de Petróleo de Paulínia (REPLAN) & Médici \\
\hline 1973 & Empresa Brasileira de Pesquisa Agropecuária (EMBRAPA) & Médici \\
\hline 1974 & Usina Hidrelétrica de Ilha Solteira & Médici \\
\hline 1974 & Ferrovia do aço & Médici/Geisel \\
\hline 1974 & Conselho de Desenvolvimento Econômico (CDE) & Geisel \\
\hline 1975 & Programa Nacional do Álcool (Proálcool) & Geisel \\
\hline 1975 & Usina hidrelétrica de Itaipu & Geisel \\
\hline 1975 & Programa Nuclear Brasil-Alemanha & Geisel \\
\hline 1976 & Usina Siderúrgica Presidente Arthur Bernardes (Açominas) & Geisel \\
\hline
\end{tabular}


Fonte: Elaboração própria, a partir de dados de tabela análoga elaborada por Ludwig (1985, p. 383), de informações do Arquivo Nacional (2012) e da bibliografia usada na dissertação.

O resultado do aumento de 8p.p. do PIB da FBCF também é perceptível por meio da alteração fundamental sofrida pela estrutura produtiva brasileira, evidenciada pelo gráfico 4. O setor agropecuário, tradicional vetor de dinamismo da economia brasileira, teve sua participação no PIB reduzida pela metade no período (para $11 \% \mathrm{em}$ 1980), enquanto o setor industrial seguiu a trajetória oposta, crescendo quase 20 pontos percentuais do PIB (para 44\% em 1980), e o setor de serviços manteve sua participação oscilando entre $51 \%$ e $55 \%$ do PIB.

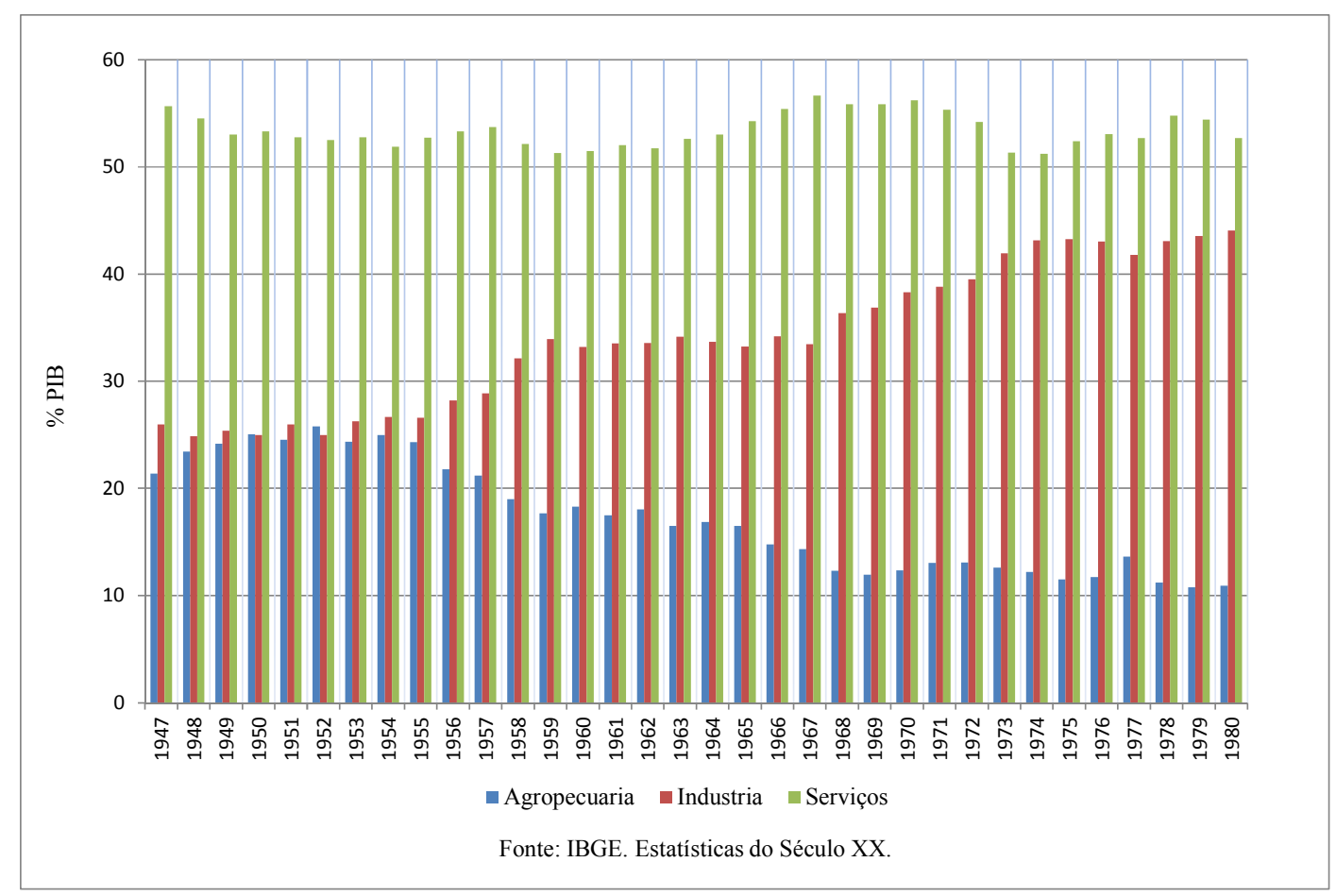

Gráfico 4 - Composição do PIB por atividade econômica, 1947-1980 ${ }^{84}$

A participação do setor de serviços encontra-se discriminada no gráfico 5 , em que se percebe um declínio das fatias referentes ao comércio e aos alugueis, as maiores durante a maior parte do período (médias de 16\% e 10\% do PIB). Em contrapartida, houve expressivo aumento dos serviços de instituições financeiras (de 3,3\% a 8,3\% do

\footnotetext{
${ }^{84} \mathrm{~A}$ soma dessas três participações é maior do que 100 porque, no cálculo do PIB, o IBGE desconta dessa soma os serviços de intermediação financeira.
} 
PIB entre 1947 e 1980), enquanto a dos serviços da administração pública oscilou entre $6 \%$ e $7 \%$ do PIB no período.

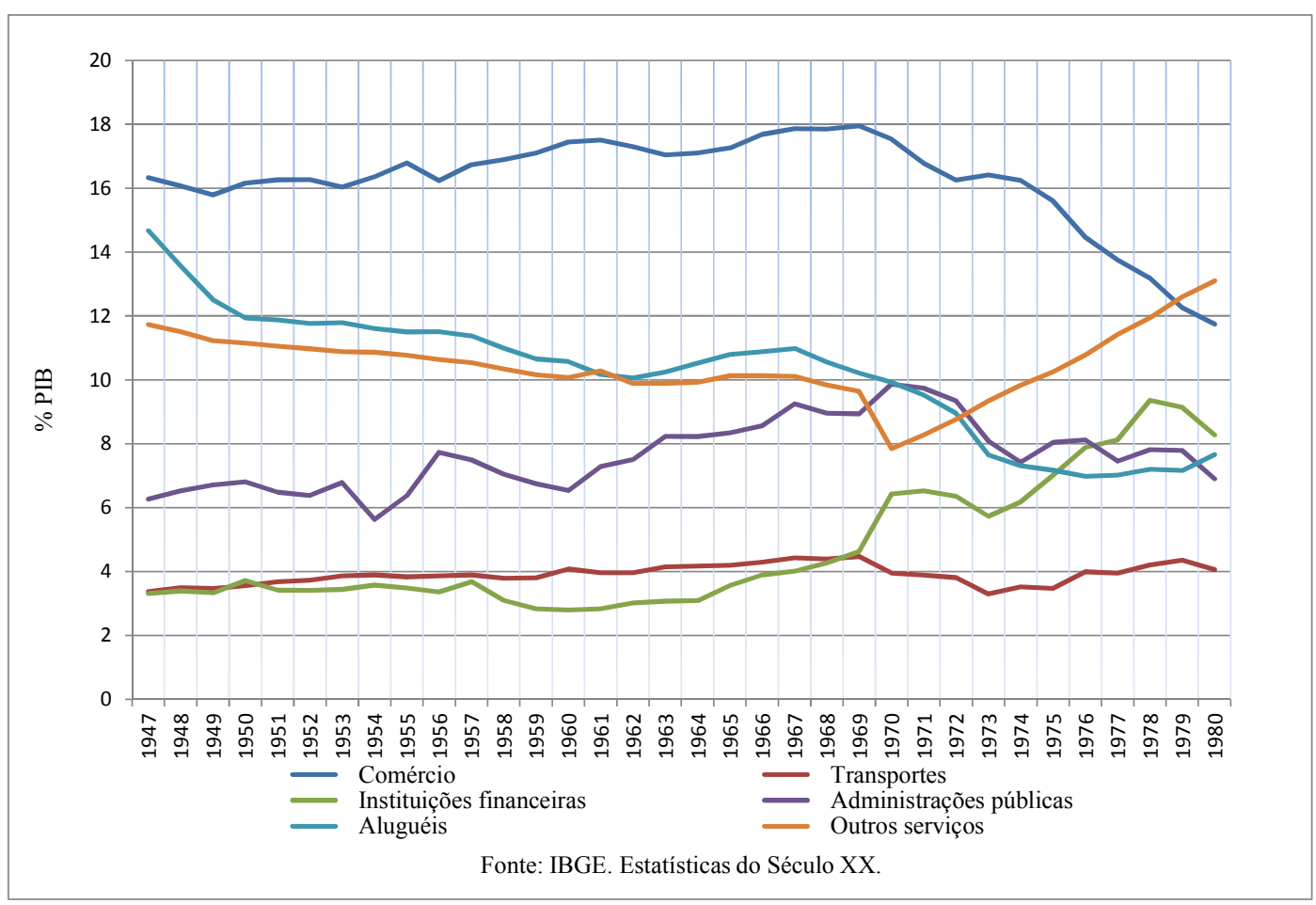

Gráfico 5 - Composição do PIB por ramos de serviços, 1947-1980

No setor industrial, o gráfico 6 mostra o destacado crescimento do segmento da indústria de transformação, que subiu 14 pontos percentuais do PIB entre 1947 e 1980, chegando a 34\% do PIB em 1980. Analisando a composição desse segmento, percebese pelo gráfico 7 uma crescente participação dos setores de maior valor agregado industrial entre 1939 e 1980: o setor de metalurgia mais que dobrou sua participação de $6 \%$ para $14 \%$, o de mecânica cresceu 8 vezes para $8 \%$, o de material elétrico e comunicações cresceu 5 vezes para 5\%, o de material de transporte quase triplicou de $3 \%$ para $8 \%$, e o de química mais que triplicou de $6 \%$ para $19 \%$. Em contrapartida, setores tradicionais de menor valor agregado como a indústria têxtil e a de produtos alimentares tiveram sua participação bastante reduzida no mesmo período, respectivamente de $23 \%$ para $6 \%$, e de $31 \%$ para $14 \%$. 


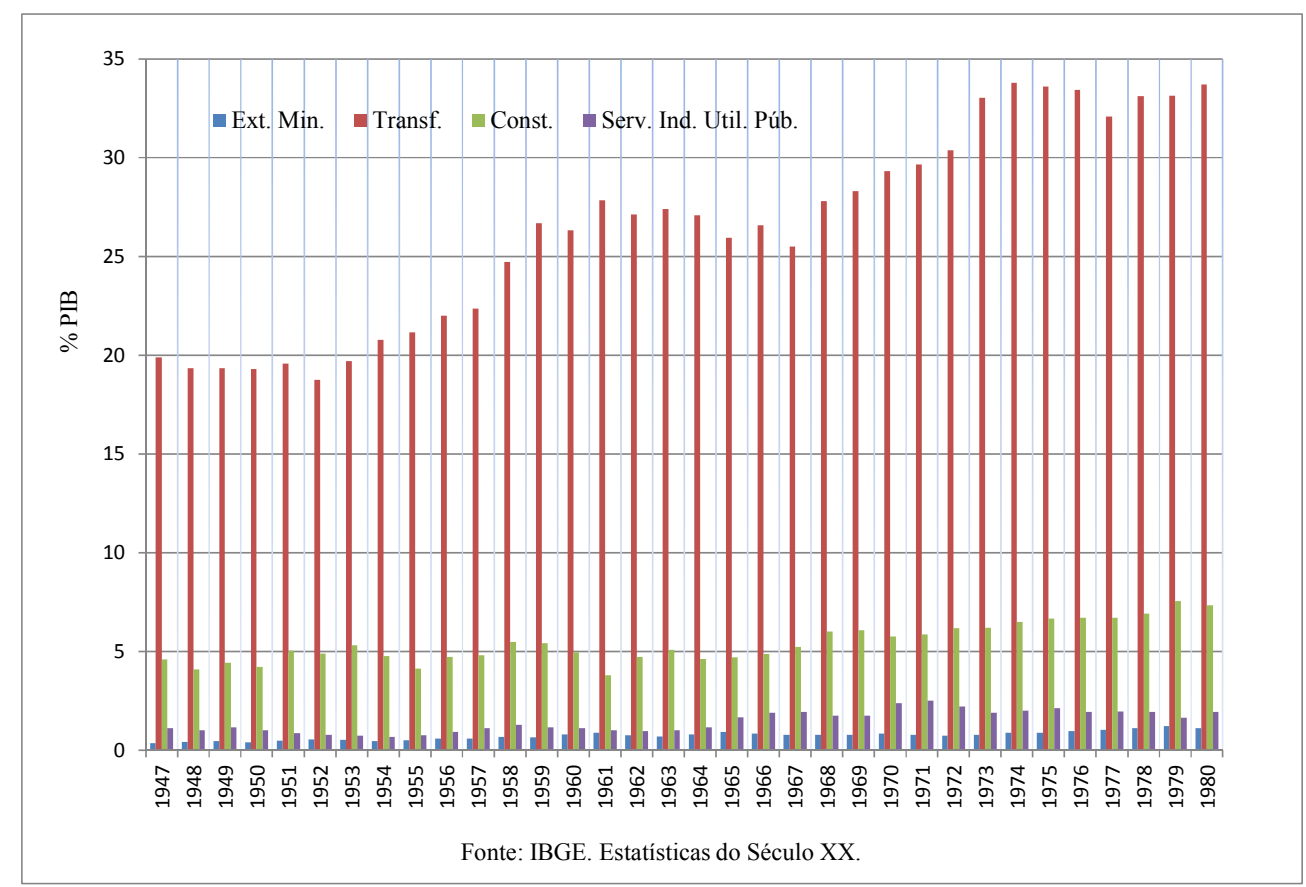

Gráfico 6 - Composição do PIB por ramos da indústria, 1947-1980

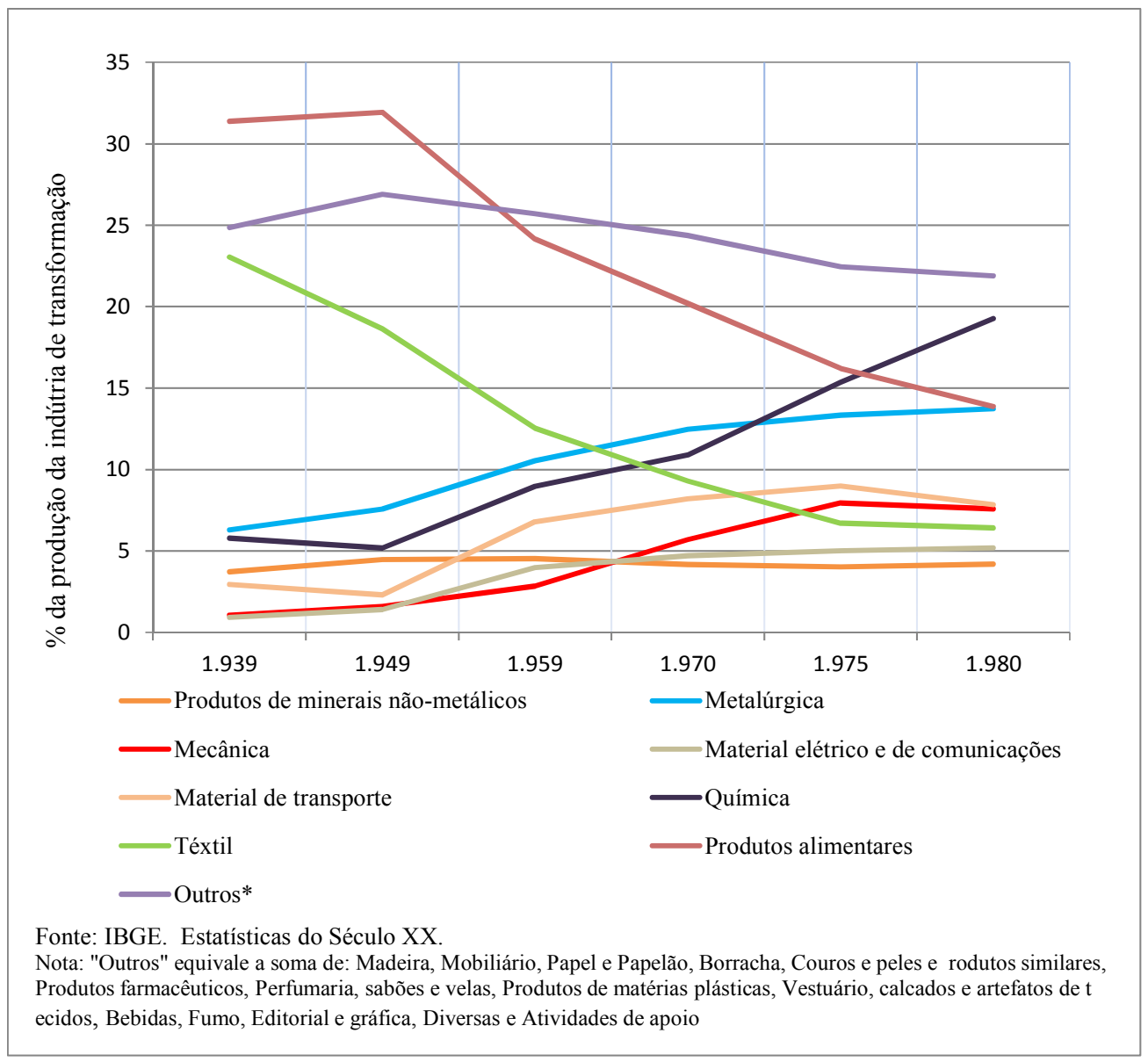

Gráfico 7 - Composição da produção da indústria de transformação, \% do total, 1939- 
O resultado dessas tendências podem ser verificado no gráfico 8 , que evidencia uma maior participação da categoria de bens de capital em relação às de bens intermediários e de consumo na segunda metade dos anos 1970.

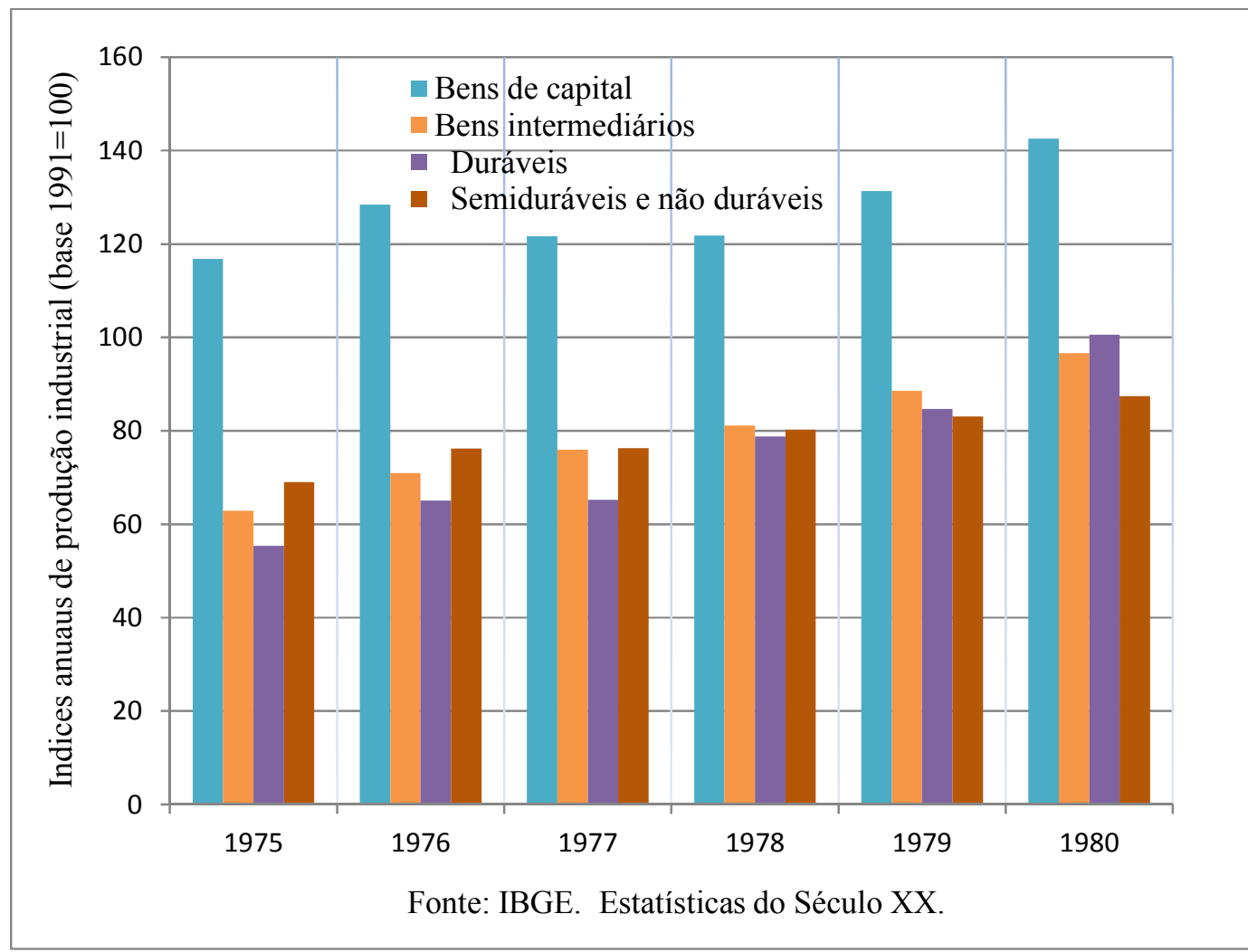

Gráfico 8 - Índices de produção industrial por categoria de uso, 1975-1980

A despeito dessa importante transformação estrutural da economia brasileira, os problemas de balanço de pagamentos decorrentes de suas relações de dependência com a economia-mundo capitalista não foram de todo solucionados. Conforme mostra o gráfico 9, uma tendência positiva é perceptível a partir dos governos militares (em contraste com a evolução predominantemente deficitária anterior), que manteve-se no entanto vulnerável às conjunturas externas, como evidenciado pelos fortes déficits comerciais sofridos durante a crise do petróleo. 


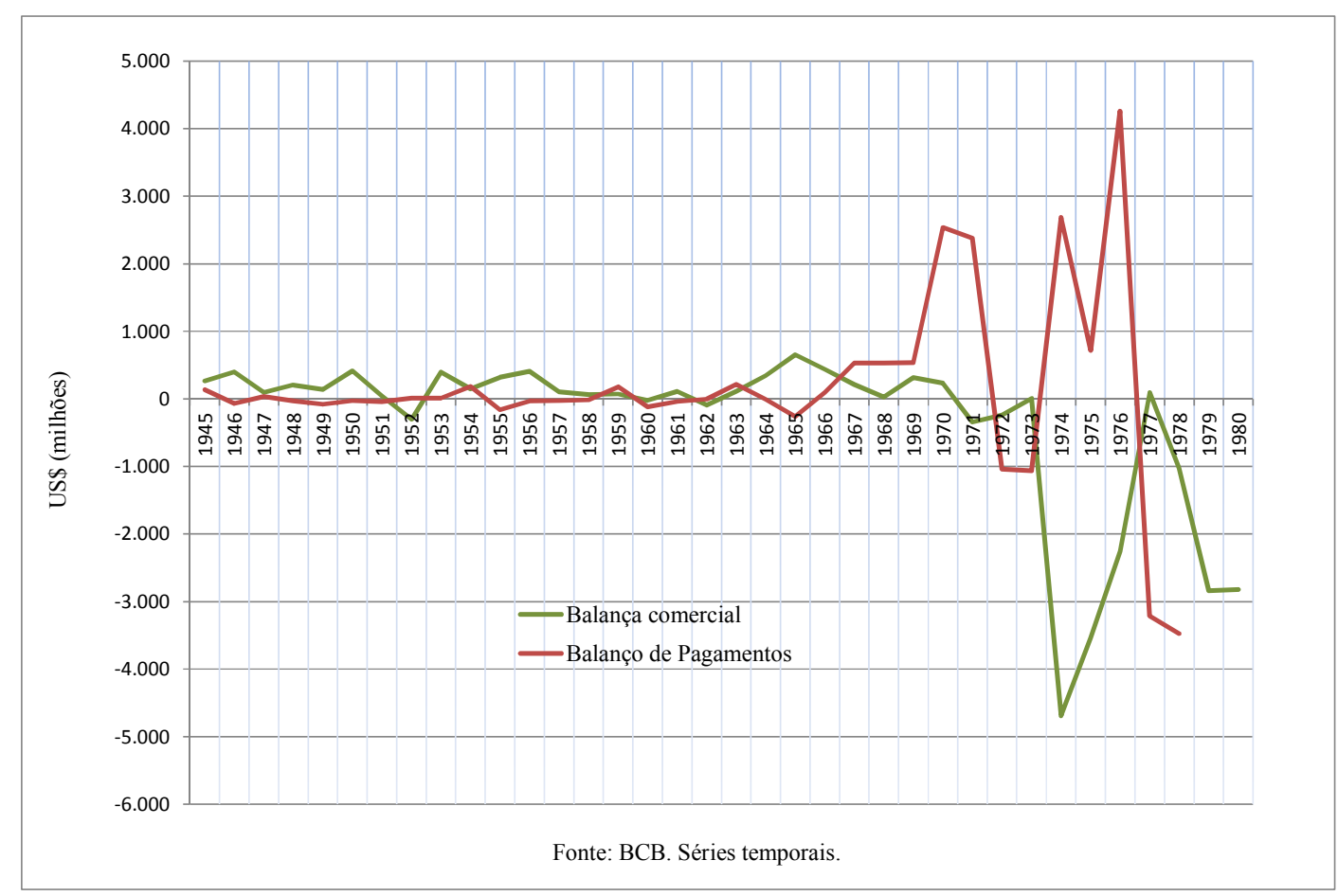

Gráfico 9 - Balanço de pagamentos e balança comercial, US\$ milhões, 1945-1980

No que tange às contas externas, o mesmo gráfico mostra que a balança comercial não seguiu a mesma trajetória do balanço de pagamentos, indicando o peso de outros fatores nas contas externas brasileiras, como os fluxos de capitais e serviços. $\mathrm{Na}$ realidade, o saldo comercial seguiu quase que em direção oposta ao balanço de pagamentos, apresentando-se predominantemente superavitário até os anos 1970 (com exceção do início do governo Vargas, fim do Kubistchek e início do Goulart) e começou a deteriorar-se mesmo antes do Primeiro Choque do Petróleo.

Nesse mesmo período, a relação dos termos de troca (relação entre preços de exportação e preços de importação) sofreu significativas oscilações, afetando de modo positivo ou negativo o desempenho do setor externo brasileiro. Em particular, a partir de 1954 há um importante movimento de declínio que durou quase uma década, dificultando o cenário para os governo de Kubistchek, Quadros e Goulart. Esse movimento foi revertido a partir de 1964, quando os termos de troca se recuperaram em meio à forte expansão da economia-mundo capitalista no período, favorecendo os governos militares que se seguiram até 1973, quando o choque do petróleo veio interromper essa tendência. 


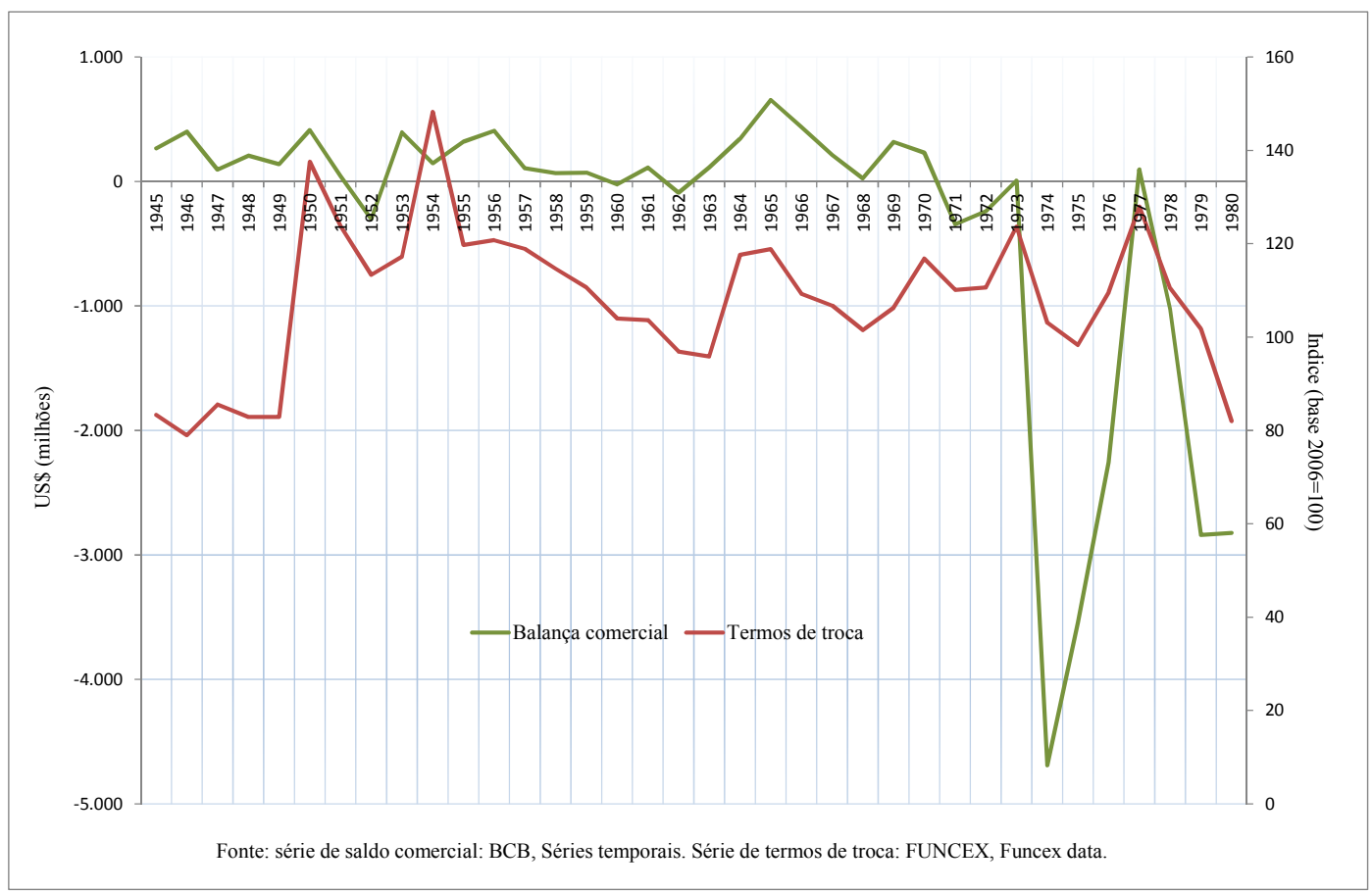

Gráfico 10 - Balança comercial e Termos de troca, US\$ milhões e Índice (2006=100), 1945-1980

De certo modo, o comportamento do saldo comercial sinaliza a ideia de que o processo de industrialização não acarretou em uma redução do total de importações. E de fato, o gráfico 11 mostra que a participação das importações no PIB teve uma redução até 1964, quando o movimento se inverteu e essa participação passou a crescer, inclusive acima da participação das exportações, chegando a 12\% do PIB em 1980.

Nesse sentido, o coeficiente de grau de abertura comercial (soma das exportações e importações em relação ao PIB) evidencia o mesmo movimento, de redução da abertura externa da economia brasileira do imediato pós-guerra até os anos 1960, e de crescimento a partir de então. Portanto, as transformações desse período não implicaram em um isolamento do exterior, mas sim em uma mudança do padrão de inserção internacional da economia brasileira em que a redução de seu grau de abertura externa realizada até os anos 1960 foi sendo revertida pelos governos militares nos anos posteriores. 


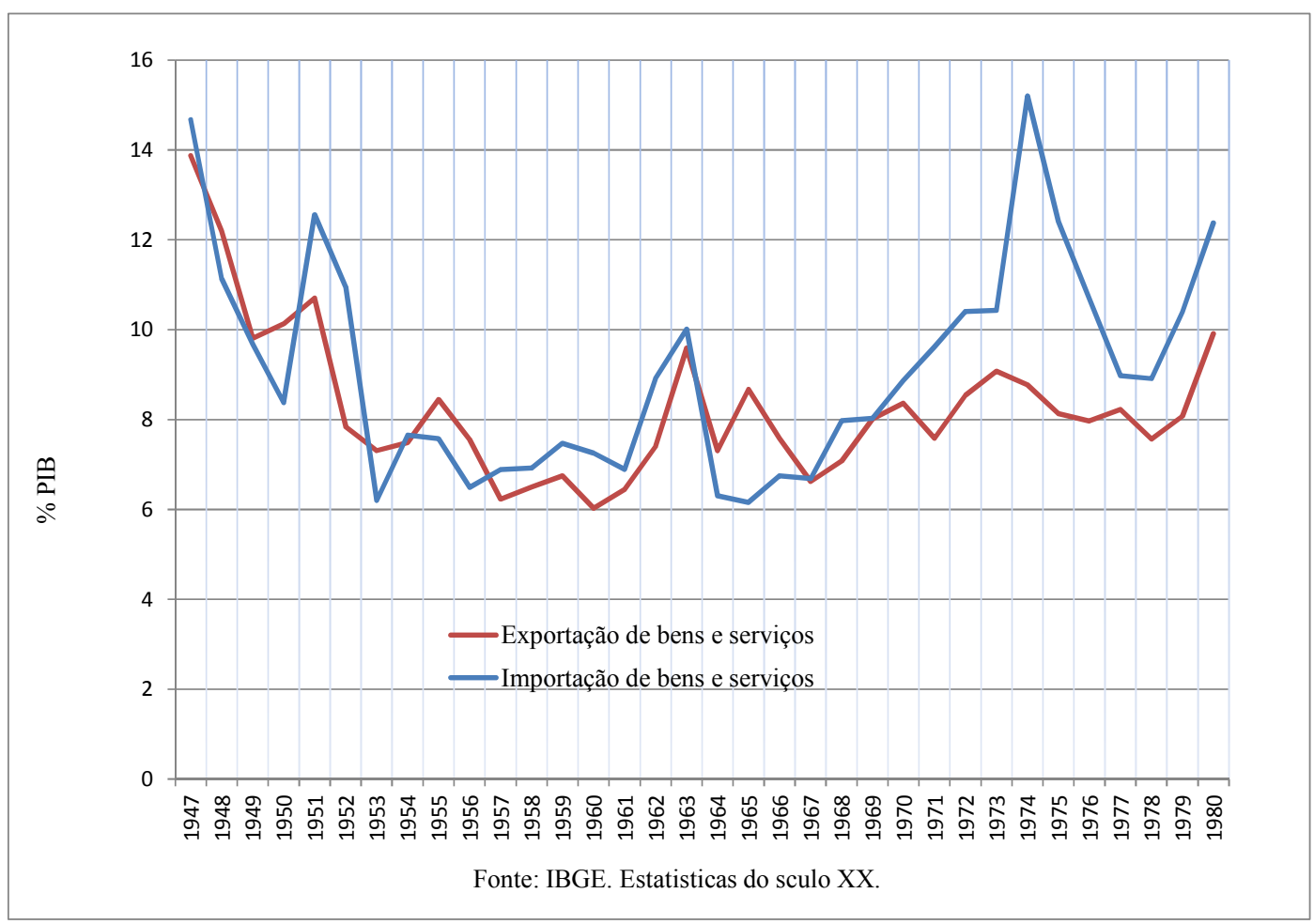

Gráfico 11 - Exportações e importações, \% do PIB, 1947-1980

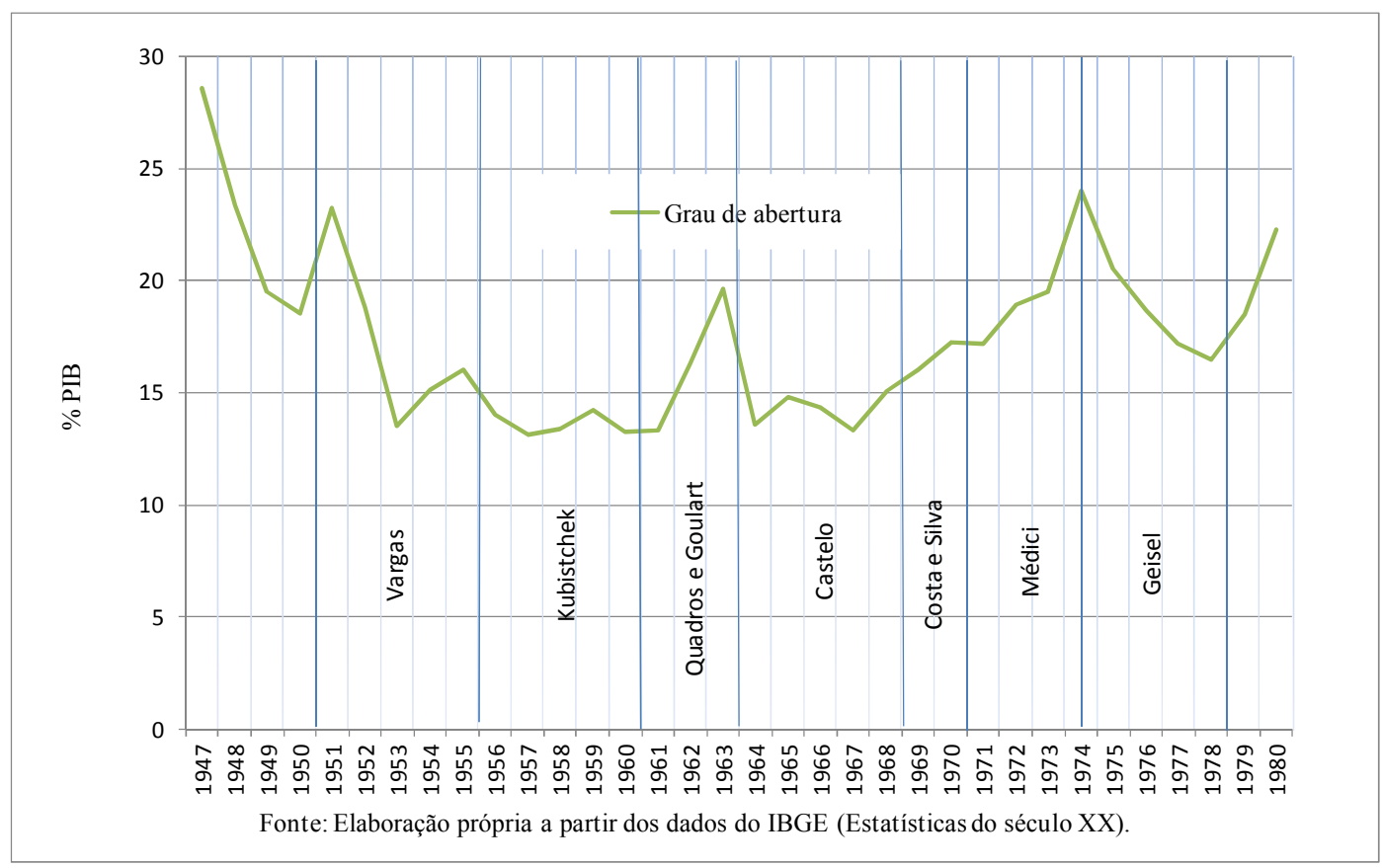

Gráfico 12 - Coeficiente de abertura econômica, \% do PIB, 1947-1980 
Por outro lado, a manutenção dessas importações foi possibilitada por um movimento análogo de aumento do valor das exportações, que permitiu manter uma capacidade de importação (definida pela quantidade exportada valorada pelos termos de troca) positiva ao longo do período, e de tendência crescente nos anos 1970, conforme mostra o gráfico 13 .

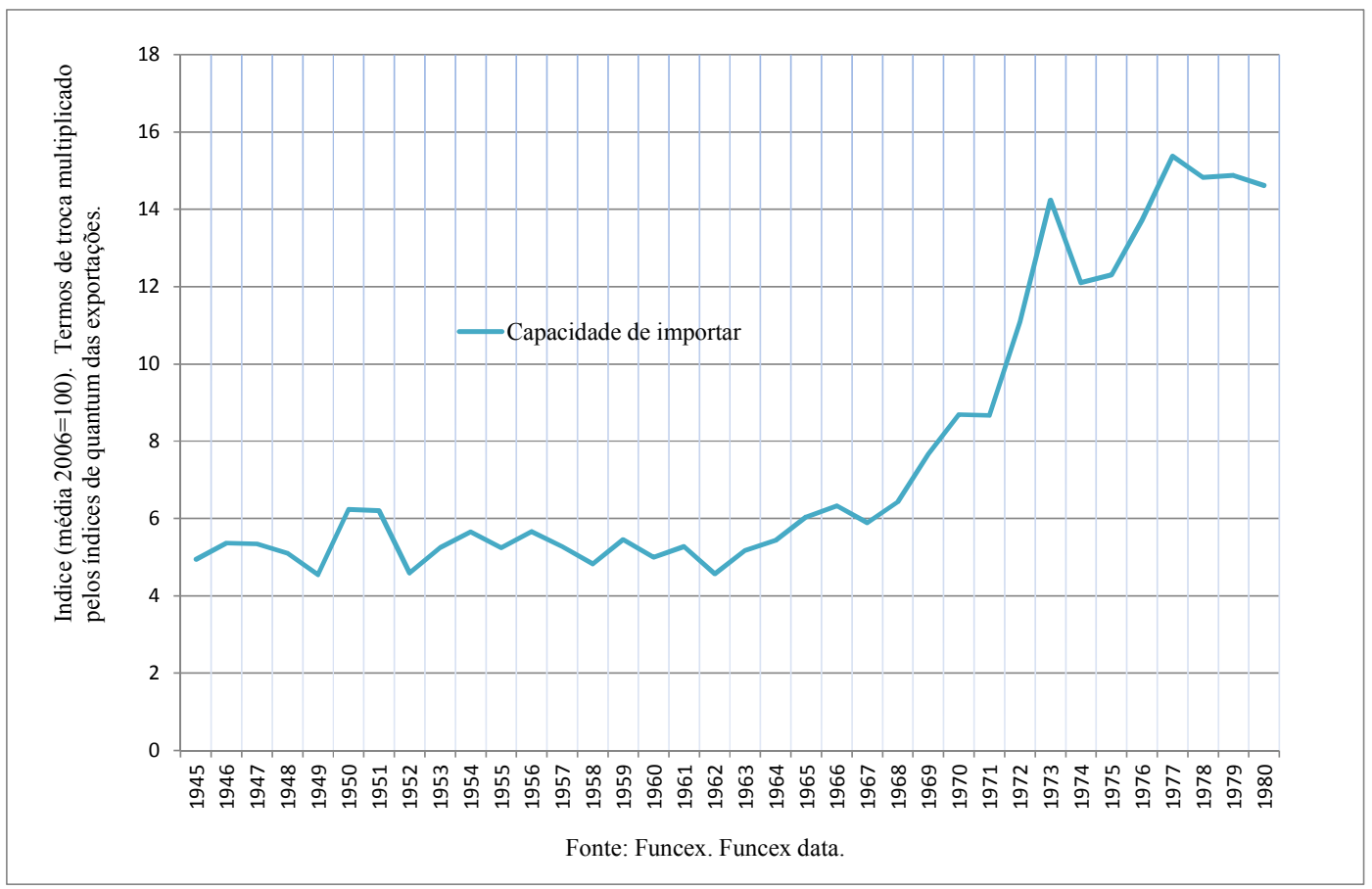

Gráfico 13 - Capacidade de importação, índice (média 2006=100), 1945-1980

Esses movimentos das exportações e importações estão intimamente relacionados às transformações da estrutura produtiva brasileira no período e suas implicações na composição da pauta de produtos exportados e importados. Nesse sentido, é perceptível um movimento de diversificação dessa pauta, conforme mostram os gráficos 14 e 15 . No caso das exportações, há uma forte redução das exportações de primários, de $70 \%$ para 42\% entre 1945 e 1980, acompanhada de um aumento paralelo das exportações de manufaturados, de $18 \%$ para $45 \%$ no mesmo período, inclusive com as exportações de manufaturados ultrapassando as de primários em 1979. 


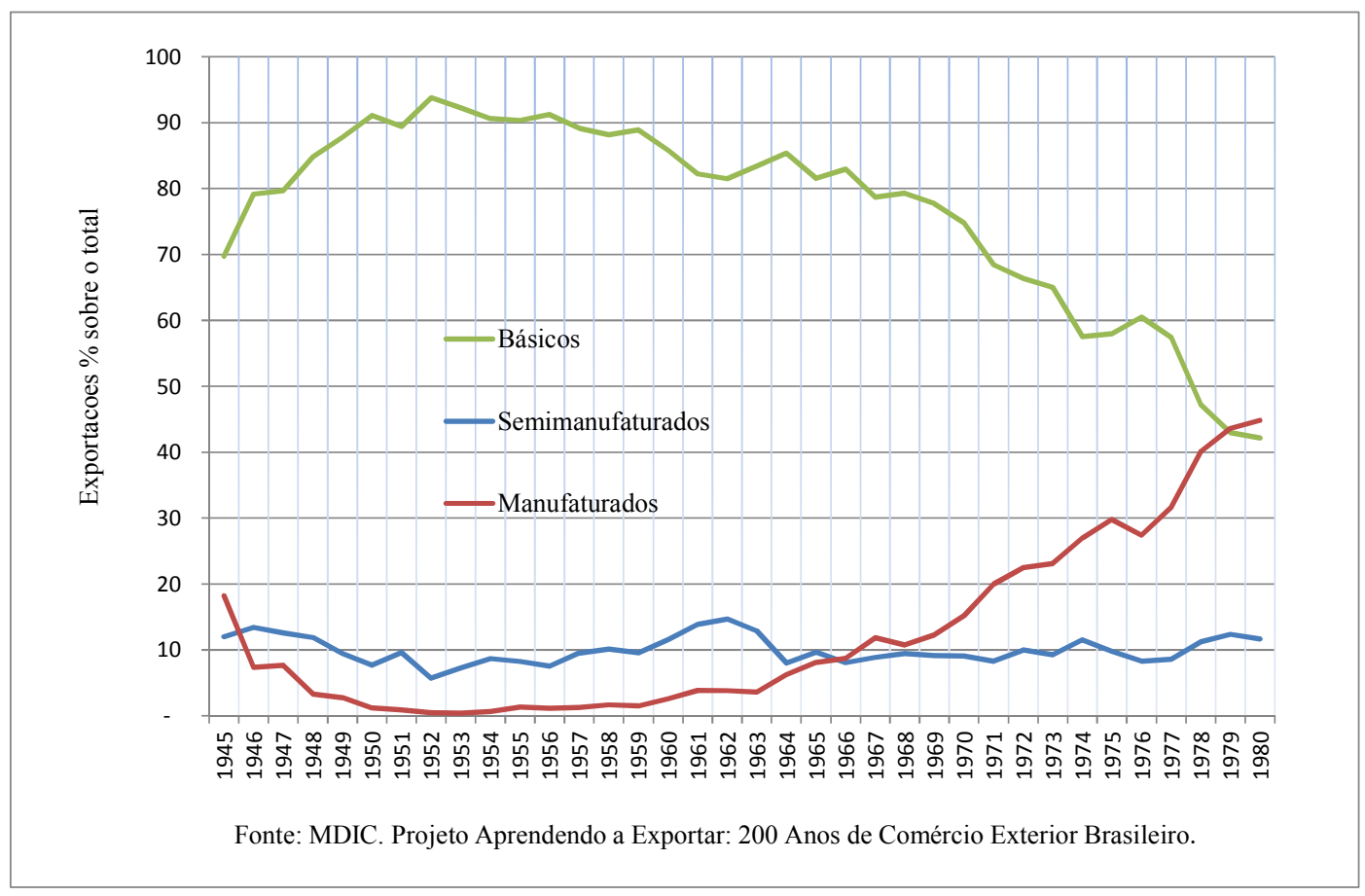

Gráfico 14 - Composição das exportações, \% total de exportações, 1945-1980

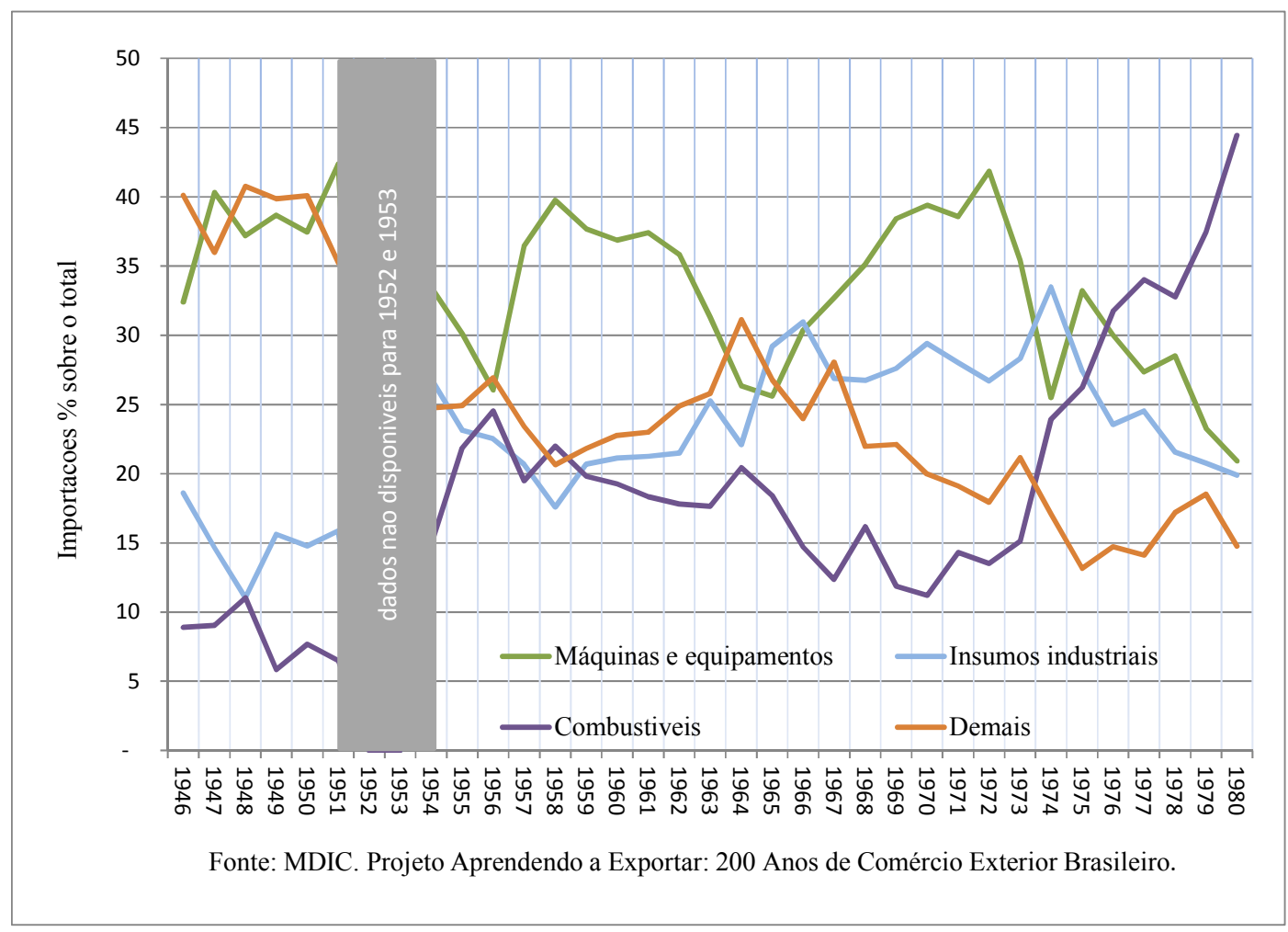

Gráfico 15 - Composição das importações, \% total de importações, 1945-1980 
No que toca às importações, percebe-se que a predominância da compra de bens de capital e "demais importações" (têxteis e produtos de origem animal e vegetal) na pauta importadora teve importante redução, passando de $32 \%$ e $40 \%$ para $21 \%$ e $15 \%$ respectivamente entre 1946 e 1980. Em contrapartida, as importações de combustíveis mais que quadruplicaram no mesmo período, passando de $9 \%$ para $44 \%$, tornando-se quase metade da pauta de importações e evidenciando a nova fonte de fragilidade externa e dependência do país decorrente de seu processo de desenvolvimento e urbanização. Já as importações de insumos industriais se mantiveram em torno de $20 \%$ do total importado no período.

Ainda houve também uma importante diversificação no que tange à composição dos destinos das exportações e das origens das importações brasileiras. Os gráficos 16 e 17 mostram que os Estados Unidos, de início o principal parceiro comercial do Brasil como destino de $50 \%$ das exportações brasileiras e fonte de $55 \%$ das importações, tiveram essas participações fortemente reduzidas para cerca de $18 \%$ em ambos os casos. Possivelmente, esses movimentos estiveram em alguma medida relacionados às tentativas de redução da tradicional subordinação brasileira aos Estados Unidos produzidas por alguns governos, à desvalorização do dólar e à redução do crescimento da própria potência hegemônica - fatores que foram acompanhados pela diversificação das parcerias internacionais buscadas pelo Brasil e pela ascensão de novos polos de dinamismo econômico no mundo. 


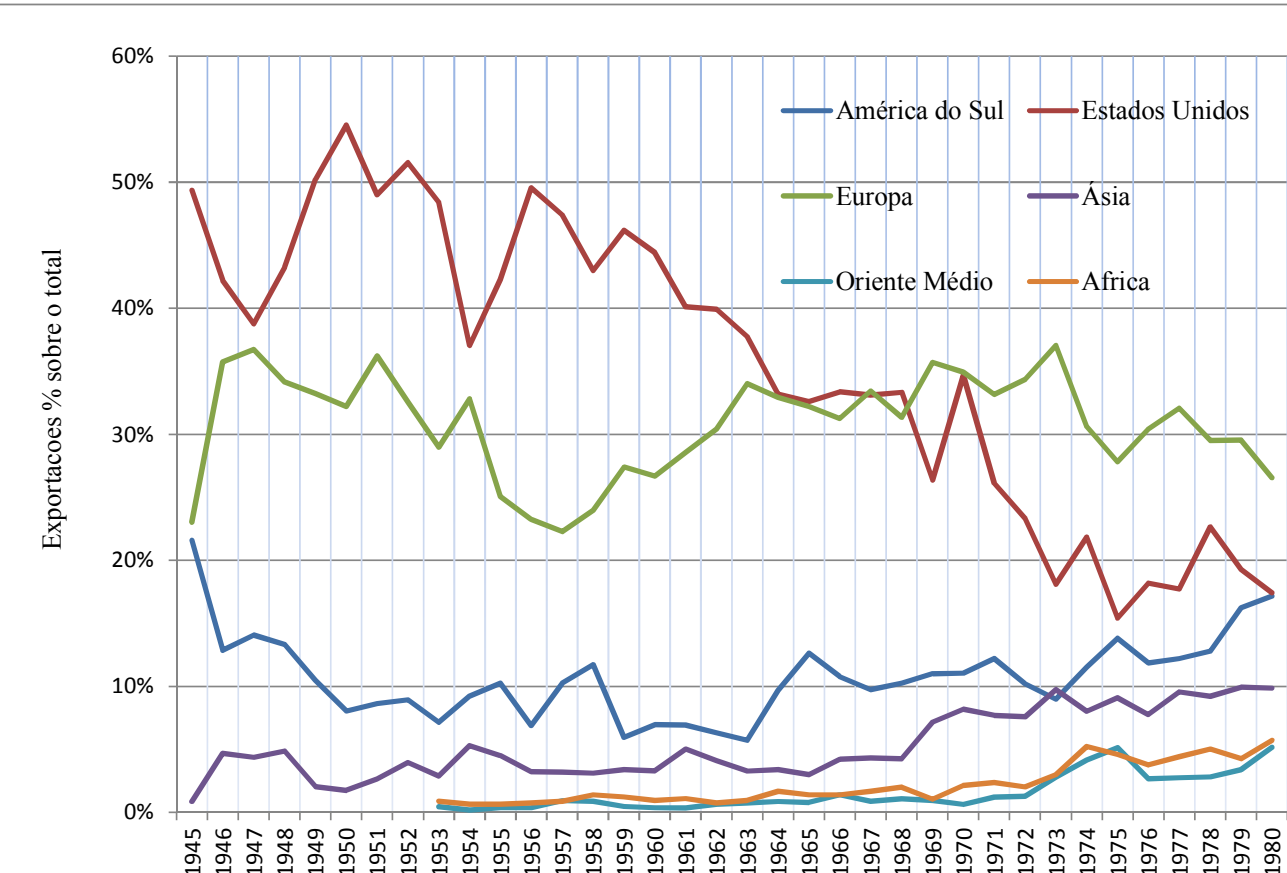

Fonte: MDIC. Projeto Aprendendo a Exportar: 200 Anos de Comércio Exterior Brasileiro.

Nota: Ate 52, Europa: Europa Ocidental; de 53 a 76, AS: ALALC e Europa: CEE; de 77 a 88, AS: ALADI e Europa: CEE

Gráfico 16 - Exportações por destino, \% total de exportações, 1945-1980

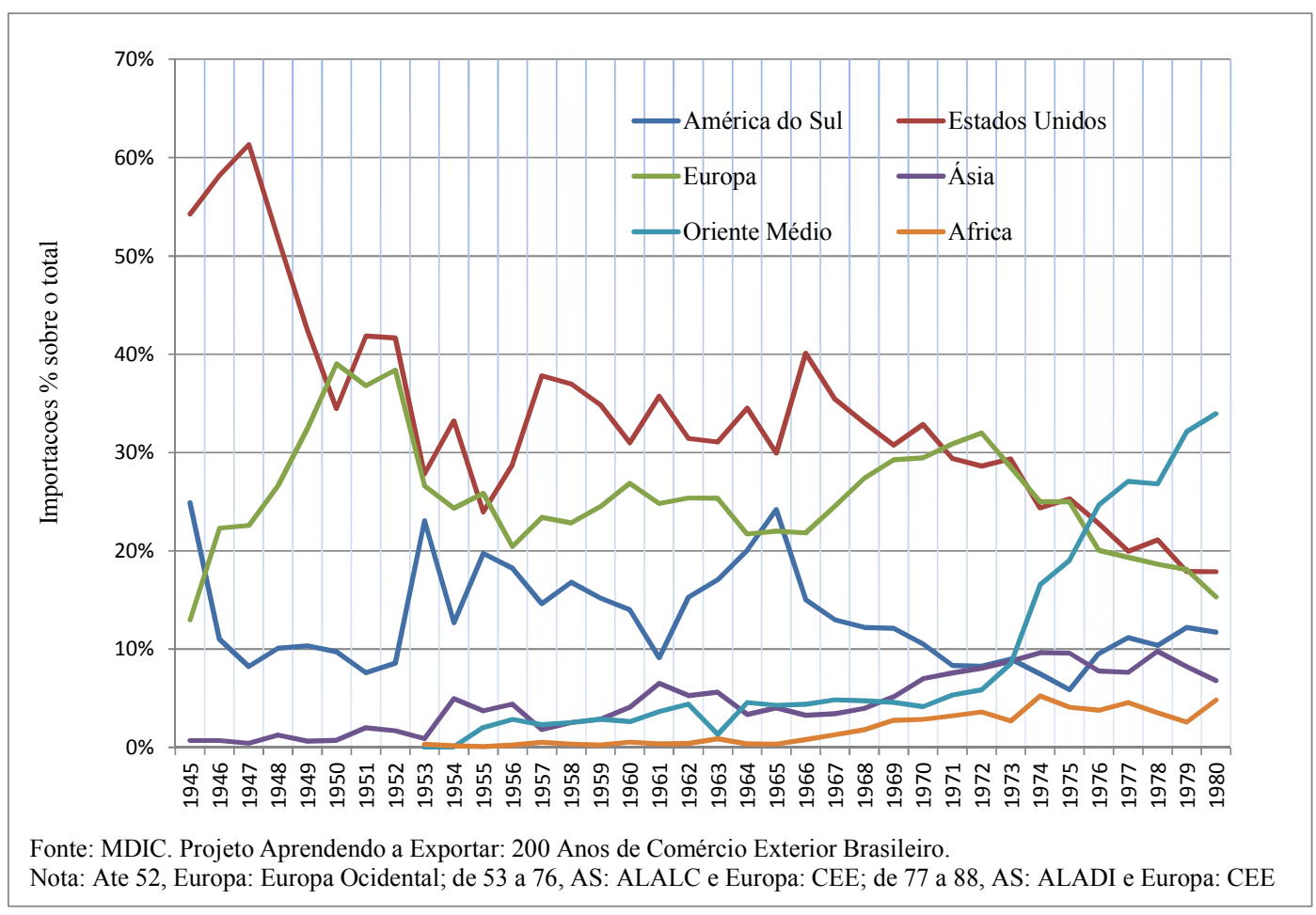

Gráfico 17 - Importações por origem, \% total de importações, 1945-1980 
As participações dos segundo e terceiro principais parceiros comerciais do Brasil, a Europa Ocidental e a América do Sul, oscilaram ao longo do período, mas no final mantiveram-se em torno dos $31 \%$ e $11 \%$ respectivamente no caso das exportações, e dos $25 \%$ e $13 \%$ no caso das importações. Já regiões cuja participação era pouco significativa no comércio exterior brasileiro, como a Ásia, a África e o Oriente Médio, foram ganhando crescente importância ao longo do período, inclusive ultrapassando em conjunto as participações dos Estados Unidos. No caso das exportações, essas participações passaram de $3 \%, 1 \%$ e $0 \%$ respectivamente no total das exportações brasileiras em 1953, para 10\%,6\% e 5\% em 1980. No lado das importações, esses números foram de $1 \%, 0 \%$ e $0 \%$ para $7 \%, 5 \%$ e $34 \%$ no mesmo período - em que este último número esteve fortemente relacionado ao crescimento das importações de petróleo.

Como resultado, o intercâmbio bilateral com os Estados Unidos, que era predominantemente favorável ao Brasil até 1965, tem sido desde então crescentemente desfavorável. Já o inverso se deu com a América do Sul, cujo saldo comercial foi predominantemente desfavorável ao Brasil até 1963, passando a ser crescentemente favorável desde então, revelando o salto industrializante realizado pelo país em relação aos demais países do continente. No caso da Europa Ocidental, o intercâmbio comercial manteve-se favorável ao Brasil em todo o período no geral, e de forma crescente a partir dos anos 1970. 


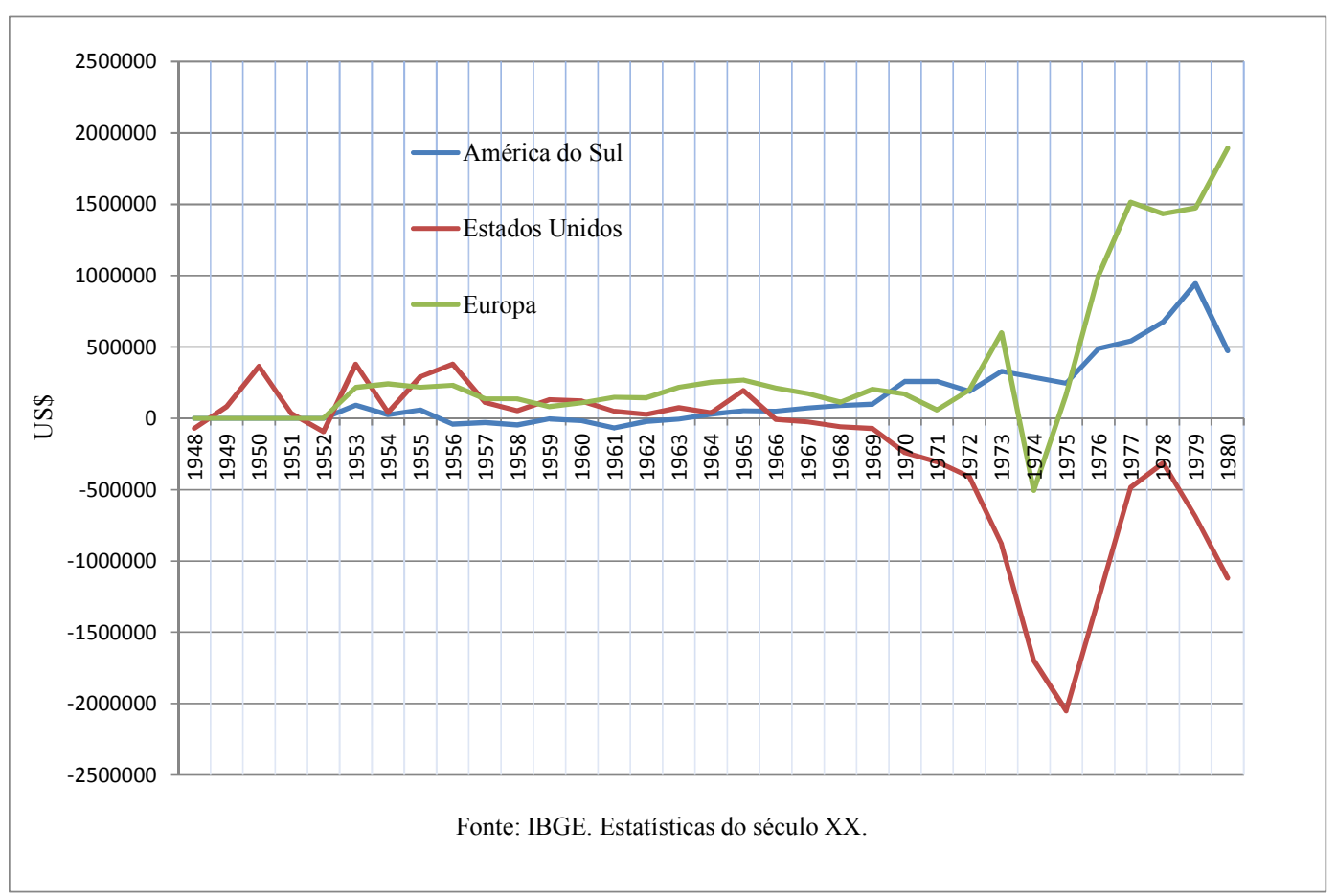

Gráfico 18 - Saldo comercial por parceiro, US\$, 1945-1980

Em contrapartida à deterioração do comércio exterior a partir de 1968, a entrada de capitais estrangeiros deu um salto no mesmo período, reflexo da ampla liquidez internacional disponível durante a fase de expansão financeira do ciclo de acumulação norte-americano. Foi possível assim, sustentar números positivos no balanço de pagamentos, a despeito dos déficits comerciais. 


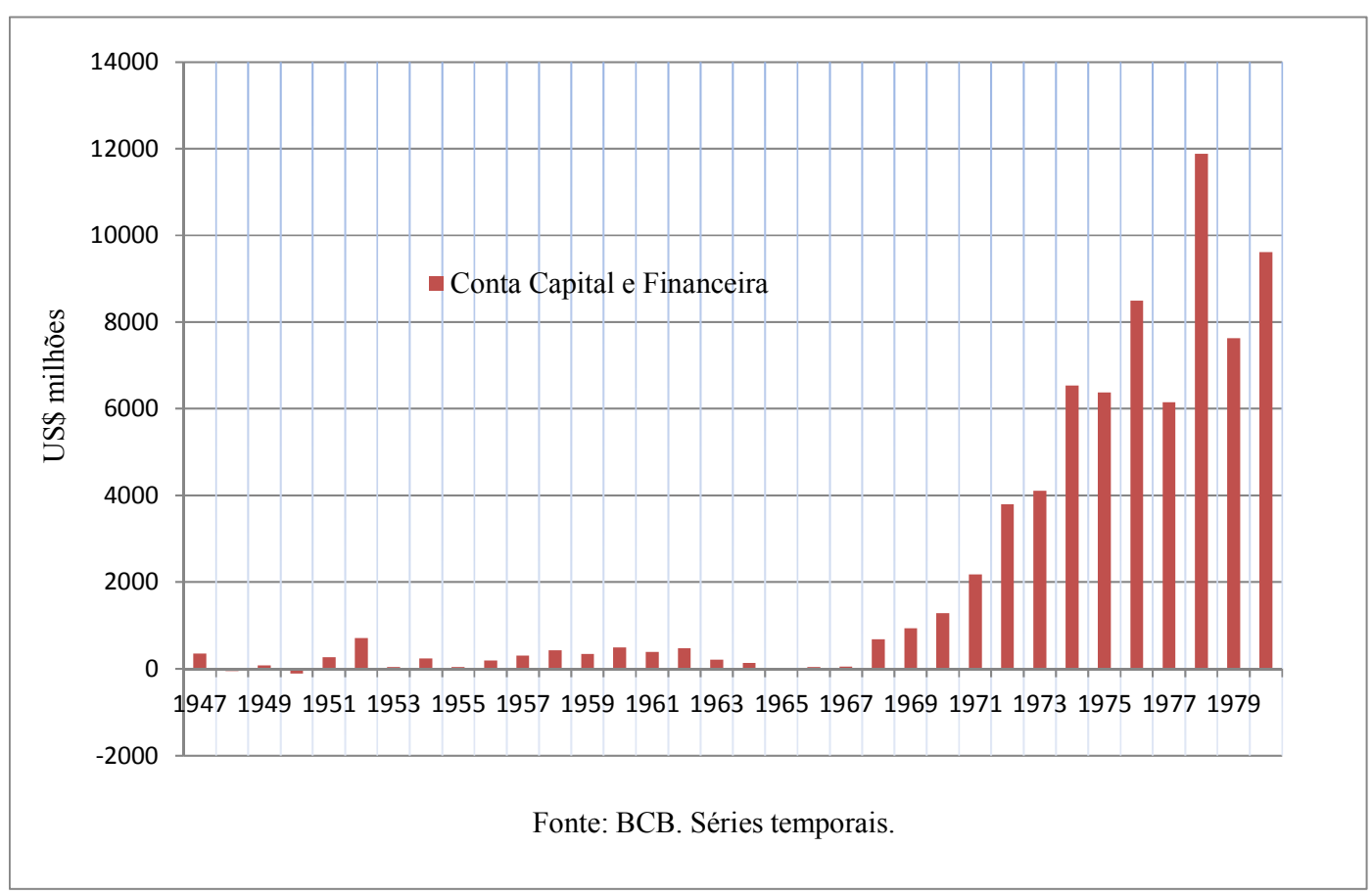

Gráfico 19 - Conta capital e financeira, US\$ milhões, 1947-1980

É interessante notar que, apesar de ter ocorrido um aumento significativo do investimento estrangeiro direto a partir do Plano de Metas (o IED mais que dobrou com relação à média de 1945 a 1954, como resultado do modelo de desenvolvimento associado e do movimento de expansão das empresas transnacionais norte-americanas), em termos relativos o salto mais significativo de entrada de capital privado estrangeiro deu-se somente a partir dos anos 1970.

$\mathrm{Na}$ realidade, conforme mostra o gráfico 20, não apenas os fluxos de investimento direto estrangeiro, mas também os de empréstimos de bancos privados estrangeiros e de financiamentos de agências multilaterais tiveram um grande impulso na década de 1970, refletindo o movimento de expansão financeira que caracterizou a economia-mundo capitalista nesse período, e que alimentou o crescente endividamento externo do governo brasileiro, com todas as suas consequências na década posterior. Em especial, o fluxo de empréstimos de bancos privados estrangeiros foi o que teve o crescimento mais expressivo no período, passando de US\$ 851 milhões para um pico de US\$ 11.310 milhões em 1978. 


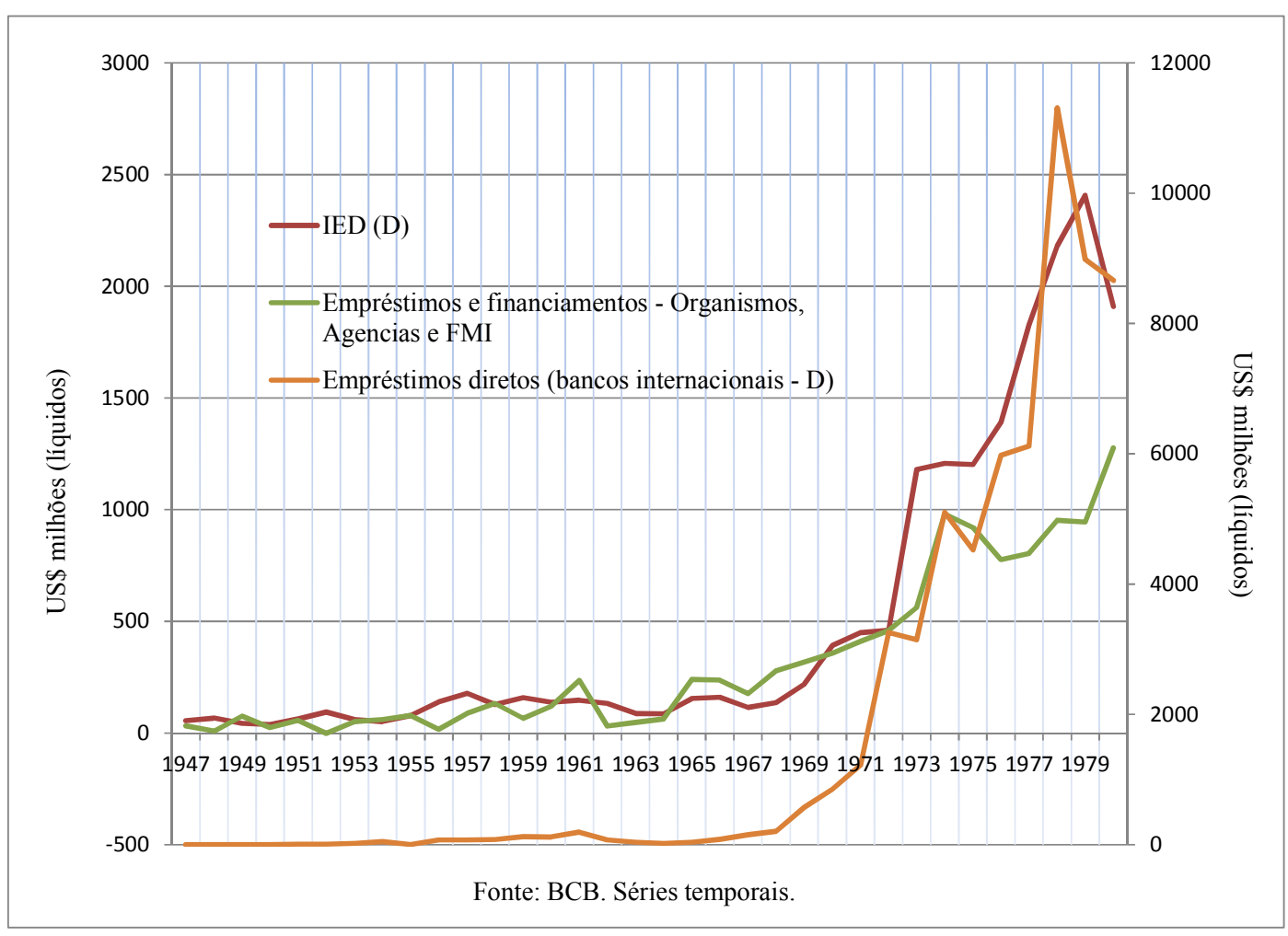

Gráfico 20 - IED, empréstimos diretos de bancos internacionais, e empréstimos e financiamentos do FMI e organismos e agências multilaterais, US\$ milhões, 19451980

Em consequência, o montante da dívida externa brasileira cresceu de US\$ 644 milhões para US\$ 105.701 milhões entre 1945 e 1980, tendo o maior crescimento ocorrido nos anos 1970, quando deu-se $95 \%$ desse aumento. 


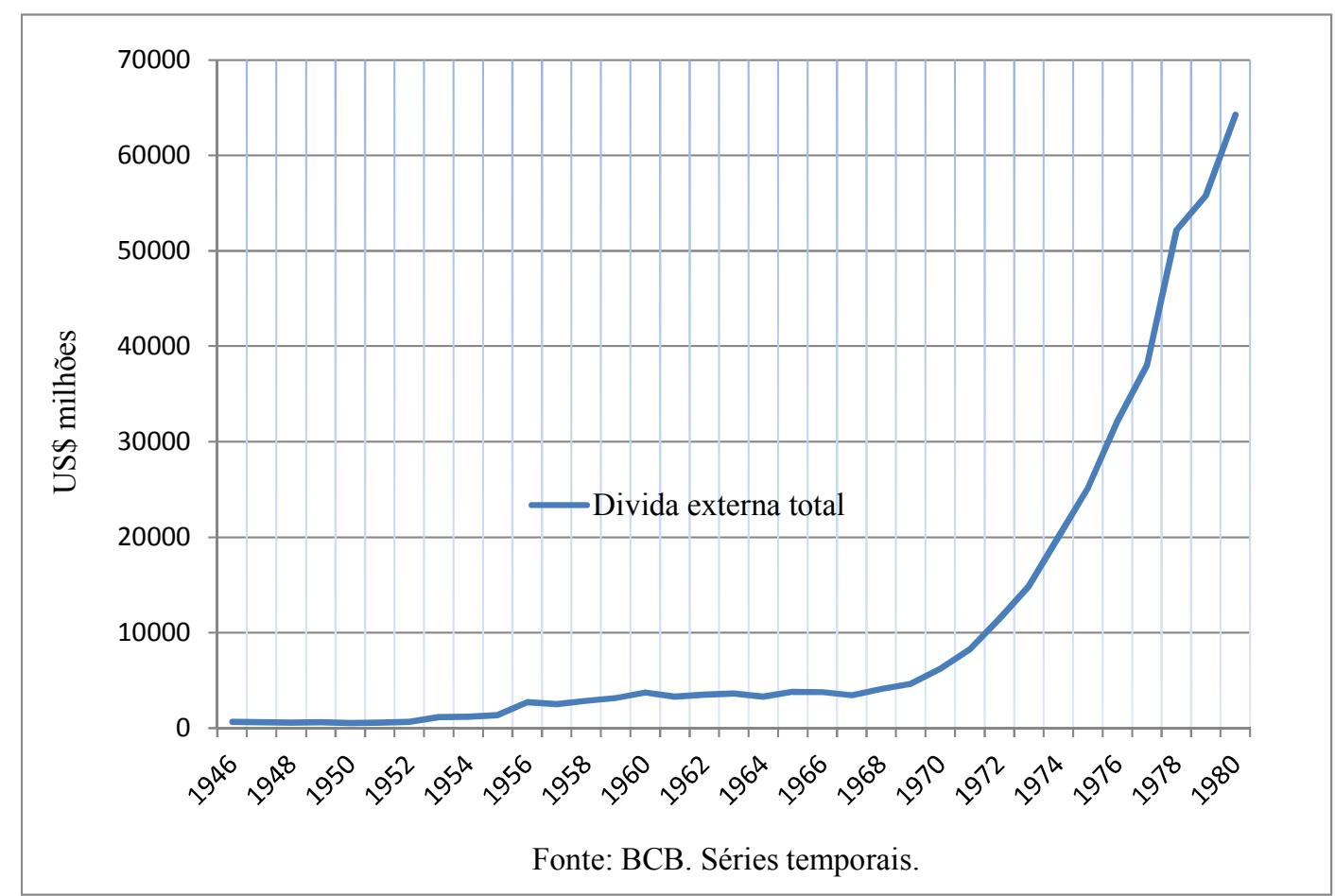

Gráfico 21 - Dívida externa brasileira, US\$ milhões, 1946-1980

A inevitável consequência dessas entradas de IED e empréstimos de bancos privados estrangeiros, além do financiamento de instituições multilaterais, foi a saída crescente de remessas de lucros e dividendos, e do pagamento de juros e amortizações. Em consonância, tanto as remessas de lucros e dividendos, quanto os pagamentos da dívida tiveram um crescimento bastante significativo no período, principalmente a partir dos anos 1970, quando deram um salto da casa das centenas de milhões de dólares para a dos milhares de milhões de dólares. 


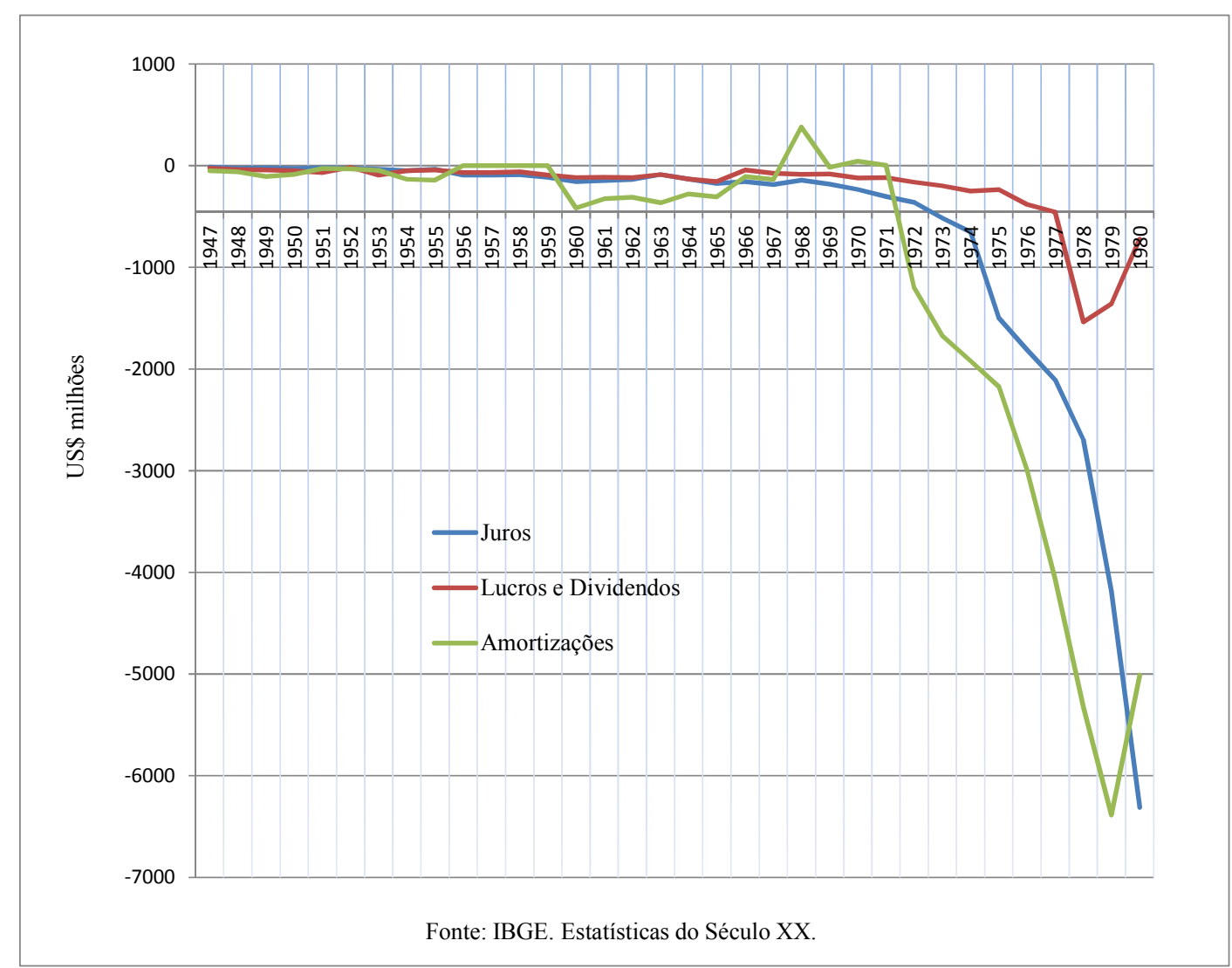

Gráfico 22 - Juros, amortizações, e lucros e dividendos, US\$ milhões, 19471980

Em especial, os pagamentos da dívida externa tiveram um aumento de mais de 26 vezes no caso dos juros, e de 112 vezes no caso das amortizações, acompanhando o crescimento de mais de 9 vezes da dívida externa total nos anos 1970.

Portanto, os dados mostram que o país conseguiu com relativo sucesso elevar sua formação bruta de capital fixo, instalando um parque industrial significativo e diversificado, em uma verdadeira transformação da estrutura produtiva brasileira, com reflexos inclusive na composição de seu comércio exterior. Não apenas aumentou-se a participação da indústria na produção nacional, como também nas vendas para outros países, denotando a transformação do país da condição de periferia tradicionalmente exportadora de primários para uma de semiperiferia exportadora de manufaturados.

Acompanhando esse movimento, deu-se também um afastamento da influência norte-americana, substituída pela diversificação das parcerias internacionais, de modo a ampliar o espaço de autonomia brasileira na busca de seus interesses nacionais, ou pelo menos diluir os seus tradicionais laços de dependência dos Estados Unidos. Desse 
modo, a nova inserção internacional da economia brasileira substituiu seu relacionamento predominantemente subordinado à potência hegemônica por uma rede de relações distribuídas entre o Primeiro e o Terceiro Mundo. De forma esquemática, tal mudança do padrão de inserção internacional da economia brasileira pode ser expressa do seguinte modo: 
$\stackrel{\infty}{\infty}$
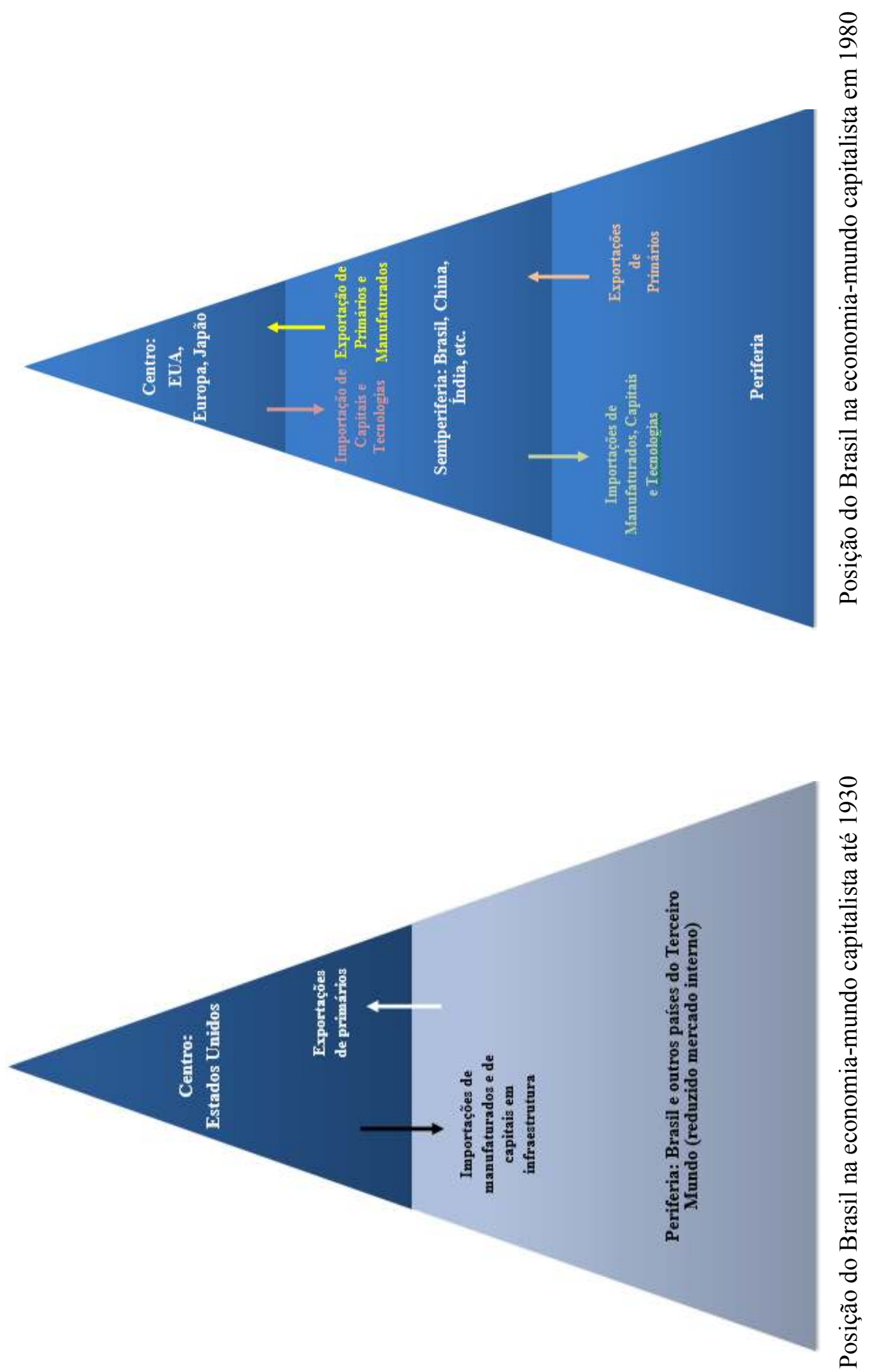
No entanto, essas transformações não implicaram na eliminação dos laços de dependência externa da economia brasileira, mas sim na sua substituição por outros tipos de vinculação. Uma das principais consequências nesse sentido foi o endividamento externo do país: o substancial crescimento da dívida externa brasileira foi acompanhado do aumento de suas obrigações em termos de juros e amortizações, onerando significativamente as contas externas e tendo graves consequências nos anos 1980. Além disso, a despeito da importante redução da dependência de bens de capital estrangeiros, originou-se uma expressiva dependência da importação de petróleo, cujos efeitos foram duramente sentidos durante as crises internacionais do petróleo.

Ficou denotado, desse modo, que a importante mudança no padrão de inserção internacional da economia brasileira envolveu a intensificação de alguns elementos de dependência e subdesenvolvimento, em um movimento que fortaleceu o primeiro termo do binômio "autonomia na dependência" ao mesmo tempo em que reformulava o segundo. A despeito dos inegáveis avanços conquistados, sumarizados pela nova posição semiperiférica e exportadora de manufaturados do país, a dependência de manufaturados estrangeiros foi substituída pela de capitais estrangeiros, produtivos e financeiros,permanecendo a economia brasileira vulnerável às oscilações da economia-mundo capitalista, embora de forma diversa ao seu histórico anterior. 


\section{CONSIDERAÇÕES FINAIS}

O objetivo deste trabalho foi avaliar o papel da política econômica e da política externa para a alteração do padrão de inserção internacional da economia brasileira entre 1945 e 1980. Buscou-se ainda analisar se houve coerência ou não entre os instrumentos desses dois eixos da política governamental, e qual foi a sua atuação em prol de movimentos por ganho de autonomia e redefinição dos canais de dependência da economia brasileira.

Conforme visto, entre 1945 e 1980, a economia brasileira sofreu grandes transformações, deixando de ser uma economia essencialmente agroexportadora da periferia para tornar-se uma economia relativamente complexa e industrializada da semiperiferia, porém ainda subdesenvolvida e vinculada aos centros de dinamismo capitalista internacional, principalmente por laços de dependência financeira e tecnológica. Mesmo assim, apesar da permanência desses desafios a serem enfrentados, o Brasil adquiriu nesse período uma abertura para atuação no cenário internacional antes inexistente, passando a exportar manufaturados ao lado de suas tradicionais exportações de primários, e aproveitando as transformações da própria estrutura de poder mundial para se afastar de sua tradicional subordinação ao centro hegemônico norte-americano, diversificar seu espectro de parcerias internacionais e buscar maior autonomia nas arenas internacionais.

Esse conjunto de transformações envolveu processos complexos de redefinição e renovação, tanto das estruturas sistêmicas relacionadas à economia-mundo capitalista, quanto das estruturas nacionais relacionadas à sociedade e economia brasileira. Nesse sentido, abarcou também as formas de inter-relação desenvolvidas entre o país e os demais atores da economia-mundo capitalista, as coalizões de poder e processos decisórios dos diversos agentes e grupos internacionais envolvidos, e as decisões e ações por eles negociadas e realizadas.

Portanto, o Estado brasileiro teve um papel fundamental para essas transformações, porém não de forma exclusiva ou isolada, tendo atuado em conjunto e por meio de diferentes formas inter-relacionais com diversos elementos estruturais e conjunturais, sistêmicos e domésticos. No que diz respeito às ações e instrumentos de política econômica e política externa, objeto desta dissertação, o conceito proposto de política de inserção internacional da 
economia brasileira (PIIEB) mostrou-se capaz de abarcar os instrumentos de ação utilizados por esses dois âmbitos de política governamental, além de permitir analisar como se deu a interação entre os instrumentos de ambos os eixos e em qual sentido deu-se as suas respectivas atuações em prol de uma alteração do padrão de inserção internacional da economia brasileira. Desse modo, ficou evidente que os instrumentos de ambos os eixos da PIIEB tiveram, ao longo do período pesquisado, um peso importante para a conformação de um novo padrão de inserção internacional da economia brasileira, atuando de forma conjunta com outros elementos relacionados às estruturas e processos decisórios tanto de agentes externos quanto internos à economia brasileira.

$\mathrm{Na}$ realidade, é preciso ter em mente que a PIIEB envolveu em sua constituição um conjunto de elementos, os quais podem ser divididos em duas dimensões: uma estrutural ou histórica, que diz respeito às estruturas historicamente constituídas tanto do sistema internacional quanto da sociedade e economia brasileira que conformaram os limites de atuação da PIIEB; e outra conjuntural, entendida como as manifestações específicas formadas a partir dos processos de decisão e coalizões de poder existentes cada momento de formulação da PIIEB.

Assim, cada um dos seis momentos que compõem o intervalo de tempo visado nesta dissertação foi caracterizado e conformado por diferentes elementos estruturais e conjunturais tanto do sistema internacional quanto da economia doméstica, implicando em distintas aberturas e possibilidades para a formulação e realização da política econômica e da política externa, para o desenvolvimento de diversas formas de interação entre os instrumentos desses dois eixos e para as suas variadas atuações sobre o padrão de inserção internacional da economia brasileira.

Desse modo, os instrumentos dos dois eixos de atuação da PIIEB variaram de feitio de um momento para outro, assim como as formas de interação que se estabeleceram entre ambos. No geral, para o período estudado, a relação alternou entre a complementaridade ou a liderança dos instrumentos de um eixo sobre os de outro. Isso não nos permite concluir que essa relação variável desenvolvida entre os instrumentos desses dois eixos reflita uma relação de complementaridade ou liderança premeditada ou conscientemente desenvolvida entre as duas políticas, ou que os momentos de aparente incoerência signifiquem uma irracionalidade 
dos processos decisórios, uma vez que tais fenômenos envolveram todo um universo de elementos em sua formulação que não foram explicitamente quantificados nessa equação.

Em específico, embora a proposta da dissertação não tenha contemplado uma abordagem detalhada da dimensão conjuntural relacionada às coalizões de poder e processos decisórios que envolveram a formulação e realização das políticas econômica e externa, tal não impediu a indicação das formas de interação que se estabeleceram entre os instrumentos de ambos os eixos a partir de uma análise restrita aos seus instrumentos de atuação: a complementaridade, a liderança ou dominância da política econômica sobre a política externa, e o inverso, a liderança ou dominância da política externa sobre a política econômica.

Desse modo, a existência de uma relação complementar entre os instrumentos dos dois eixos em um determinado momento refletiu uma combinação de fatores no âmbito das duas políticas que permitiu a ambas utilizar instrumentos que se reforçaram na produção de um determinando efeito sobre o padrão de inserção internacional da economia brasileira. Alternativamente, quando essa interação se deu sob a forma da liderança dos instrumentos de um eixo sobre o outro, a ausente ou reduzida complementaridade no geral resultou de aberturas diferenciadas colocadas aos dois eixos para empreender iniciativas, ou da limitada capacidade do Estado brasileiro de aproveitar o potencial de intervenção de um desses dois eixos, limitando o alcance da PIIEB e os resultados que poderiam ser alcançados sobre a inserção internacional da economia brasileira.

Os casos dos governos Kubistchek e Quadros/Goulart são exemplos paradigmáticos desse fenômeno: no primeiro, os instrumentos da política econômica demonstraram um alcance muito maior para intervir, ou pelo menos influenciar de alguma forma, sobre o padrão de inserção internacional da economia brasileira do que os instrumentos da política externa, conforme evidenciado pela incapacidade da Operação Pan-americana em adequar a política externa brasileira às necessidades do desenvolvimento nacional frente às transformações do contexto internacional. Já no segundo caso deu-se o inverso, tendo os instrumentos da política externa demonstrado grande habilidade de atuação e iniciativa, principalmente por meio da Política Externa Independente, enquanto o campo de atuação da política econômica viu-se tolhido pelas dificuldades do cenário político-econômico nacional, de tal forma que a política 
externa acabou assumindo um protagonismo antes inexistente como instrumento do desenvolvimento e da busca por maior autonomia do país no cenário internacional.

Por fim, a aplicação do conceito de "autonomia na dependência" de Moura (1980) ao período estudado mostrou-se útil para sinalizar a atuação da PIIEB sobre o padrão de inserção internacional da economia brasileira, indicando um movimento de idas e vindas entre a autonomia e a dependência, sem nunca chegar a conquistar nem a total autonomia nem a total dependência. A cada momento esse binômio foi sendo reformulado, redefinindo tanto os elementos de autonomia quanto os de dependência da economia brasileira. Entretanto, no geral o movimento total do período foi em direção a um ganho de maior autonomia, com a transformação da estrutura produtiva brasileira, o fortalecimento do mercado interno e da dinâmica de acumulação de capital nacional, e o afastamento da dependência norteamericana, embora tenha se mantido "um pé" no lado da "dependência", com os elementos de subordinação ao exterior da economia brasileira sendo redefinidos em meio a esses processos de transformação, até mesmo intensificando alguns de seus vínculos de vulnerabilidade e subdesenvolvimento

Portanto, o processo de transformação do padrão de inserção internacional da economia brasileira entre 1945 e 1980 foi um movimento que, para o período como um todo, fortaleceu o primeiro termo do binômio "autonomia na dependência" ao mesmo tempo em que reformulava o segundo, em uma trajetória de idas e vindas, em que os instrumentos de ambos os eixos da política de inserção internacional da economia brasileira tiveram uma atuação fundamental. Ao lado das forças estruturais e conjunturais nacionais e internacionais que compuseram esse horizonte de transformação, a PIIEB foi importante e estratégica para essa alteração do padrão de inserção internacional da economia brasileira.

Em termos de contribuição para futuras análises dos processos subsequentes de transformação do padrão de inserção internacional da economia brasileira, acredita-se que o arcabouço aqui construído possa ser útil para avaliar o papel da política econômica e da política externa em outros períodos, tendo em vista as particularidades específicas que conformaram o contexto doméstico e internacional em cada momento histórico.

Assim, a título de ilustração, pode-se aventar que o processo de expansão financeira que caracterizou a economia-mundo capitalista nos anos 1970, quando o capital internacional voltou a concentrar-se em sua forma financeira na busca de maiores oportunidades de lucro 
pelo mundo, encontrou no Brasil uma conjuntura favorável, em que ambos os instrumentos de política econômica e externa buscavam fomentar um processo de expansão material no país, e acabaram aproveitando a ampla liquidez disponível nos mercados internacionais para receber crescentes entradas de capitais estrangeiros tanto sob a forma de investimentos diretos quanto sob a forma de empréstimos e financiamentos.

Entretanto, na década seguinte, os Estados Unidos voltaram a concentrar e controlar a liquidez internacional por meio de uma aliança de Washington com as altas finanças, retomando a expansão das taxas de lucros norte-americanas e promovendo um novo ciclo de prosperidade nos países do Primeiro Mundo, que realizaram um importante salto tecnológico nos anos 1980. Em contrapartida, essa recentralização do capital no centro da economiamundo capitalista, com a alta dos juros internacionais que a acompanhou, reverteu o fluxo de entrada de capitais que alimentava os processos de expansão material no Brasil.

Não apenas viu-se o país acometido com pesadas obrigações da dívida externa sob condições de juros desfavoráveis, como também a demanda mundial por suas exportações foi reduzida com o aperto monetário norte-americano, enquanto o preço internacional do petróleo manteve-se significativamente elevado nos anos 1980 e a inflação doméstica se acelerava. Essas condições acabaram por reprimir a economia, ao mesmo tempo em que tanto os instrumentos de política econômica e de política externa mostraram-se incapazes de atenuar esses problemas de modo mais significativo, abafados pelo peso das dificuldades que passaram a assolar o país. Revertia-se, assim, o movimento que fortalecera o primeiro termo do binômio "autonomia na dependência" na década anterior, com as formas de dependência reformuladas nos anos 1970 passando a se manifestar com maior força, determinando um maior peso para o segundo termo do binômio durante a que ficou conhecida como a "década perdida" da economia brasileira.

$\mathrm{Na}$ década seguinte, a forte expansão econômica sustentada pelos Estados Unidos nos anos 1980 logo começou a demonstrar sinais de exaustão, com uma nova onda financeira voltando a espraiar-se pelo mundo e os mercados acionários sustentando o que Greespan (1996) chamou de "exuberância irracional”. No Brasil, os instrumentos de política econômica buscaram resolver os problemas que se aguçavam desde a década anterior por meio da abertura econômica, das privatizações e do ajuste fiscal e monetário. No âmbito da política 
externa, as relações regionais e com o Primeiro Mundo ganharam prioridade, com o foco recaindo sobre a integração sul-americana e a cooperação com os Estados Unidos e a Europa.

Embora os problemas de solvência externa e desequilíbrio inflacionário tenham sido resolvidos com relativo sucesso, as medidas de política econômica e política externa dos anos 1990 tiveram como contrapartida o adicional enfraquecimento de alguns elementos que haviam conferido maior autonomia à economia brasileira nos anos 1970, como a capacidade do Estado de conduzir o processo de desenvolvimento e o fortalecimento da estrutura produtiva nacional. Se por um lado a estabilidade econômica proporcionou condições para dinamizar a economia, por outro lado ampliou-se a dependência tecnológica do exterior em diversos setores industriais, além do crescimento da vulnerabilidade aos capitais estrangeiros, principalmente aos fluxos especulativos e de curto prazo.

Essa vulnerabilidade financeira do exterior foi duramente sentida na passagem dos anos 1990 para os anos 2000, quando o quadro brasileiro da crise de desvalorização cambial de 1999 foi complicado pela crescente instabilidade financeira internacional, com destaque para a crise da bolha da internet e o cenário de quase estagnação da economia norte-americana com ampla liquidez disponível que a seguiu.

Já nos anos 2000, mesmo com o objetivo de acalmar os mercados e manter o tripé "metas de inflação-câmbio flutuante-superávit primário da política econômica", o governo retomou a ênfase no mercado interno, o papel central do Estado como gerenciador do desenvolvimento econômico, e de elementos que remetem à política externa independente, como a cooperação Sul-Sul em prol do desenvolvimento e da reforma das assimetrias do sistema internacional. Retomou, portanto, elementos que atuaram em prol de um ganho de autonomia durante o período estudado de 1945 a 1980, reformulando-os e traduzindo-os para as novas condições vigentes no cenário internacional e doméstico da economia brasileira.

$\mathrm{Na}$ realidade, essas últimas rápidas conjecturas apenas pincelam de modo indicativo as possibilidades de análise despertadas pelas perspectivas deste trabalho, apontando para futuras pesquisas sobre o papel e importância da política econômica e da política externa para as transformações do padrão de inserção internacional da economia brasileira que caracterizaram os anos 1980, 1990 e 2000, até a grande crise de 2008.

Portanto, o enfoque metodológico desenvolvido em torno do conceito da política de inserção internacional da economia brasileira, tendo em vista o arcabouço teórico da 
economia-mundo capitalista, as interpretações histórico-estruturais e as formulações da área de relações internacionais sobre a inserção internacional da economia brasileira, mostrou-se útil para analisar a atuação da política econômica e da política externa na transformação do padrão de inserção internacional da economia brasileira. Conforme visto, esta atuação variou ao longo do período estudado de acordo com o conjunto de possibilidades determinados pelas estruturas e conjunturas envolvidas a cada momento, alternando entre a complementaridade e a liderança dos instrumentos de um eixo sobre o outro, e contribuindo para diferentes atuações da PIIEB sobre o padrão de inserção internacional da economia brasileira, em um movimento de reinterpretação dinâmica dos dois termos do binômio "autonomia na dependência”. 


\section{REFERÊNCIAS BIBLIOGRÁFICAS}

ABREU, Marcelo de Paiva. Anexo estatístico 1939-1949, 1950-1969, 1970-1987. In:

(org.). A ordem do progresso: cem anos de política econômica republicana, 1889-1989. 13ª Tiragem. Rio de Janeiro: Campus, 1990, p. 398-412. - Inflação, estagnação e ruptura: 1961-1964. In: (org.). A ordem do

progresso: cem anos de política econômica republicana, 1889-1989. 13 ${ }^{\text {a }}$ Tiragem. Rio de Janeiro: Campus, 1990, cap. 7, p. 197-212.

AMADO, Rodrigo. A política externa de João Goulart. In: ALBUQUERQUE, José Augusto Guilhon (org.). Sessenta anos de política externa brasileira (1930-1990). São Paulo: Cultura Editores, 1996-2000: Núcleo de Pesquisas em Relações Internacionais da USP. v. 1: Crescimento, modernização e política externa.p. 283-297.

ARQUIVO NACIONAL (Brasil).Os presidentes e a Republica: Deodoro da Fonseca a Dilma Rousseff. 5a Edição revista e ampliada. Rio de Janeiro: O Arquivo, 2012.

ARRIGHI, Giovanni. Adam Smith em Pequim: origens e fundamentos do século XXI. Tradução Beatriz Medina. Apresentação Theotonio dos Santos. São Paulo: Boitempo Editorial, 2008.

. O longo século XX: dinheiro, poder e as origens do nosso tempo. Tradução Vera Ribeiro. Revisão de tradução César Benjamin. São Paulo: Editora Unesp, 1996.

- The developmentalist illusion: a conceptualization of the semiperiphery. In: MARTIN, W. G. (ed.). Semiperipheral states in the world economy. Advisor Editor Immanuel Wallerstein. Westport (CT): Greenwood Press, 1990. Cap. 2, p. 11-42.

BADO, Álvaro Roberto Labrada. A política econômica externa do governo Castelo Branco (1964-1967). 2006. 226 fls. Tese (Doutorado em História Econômica) - Faculdade de Filosofia, Letras e Ciências Humanas, Universidade de São Paulo, São Paulo, 2007.

BANCO CENTRAL DO BRASIL. Boletim do Banco Central do Brasil: Relatório Anual 2010.Brasília, DF: BCB, v. 46, 2010. 
BANCO CENTRAL DO BRASIL.Relatório de Estabilidade Financeira: Abril de 2010. Brasília, DF: Banco Central do Brasil, v. 9, n. 1, Abril 2010.

BANCO CENTRAL DO BRASIL. Sistema Gerenciador de Séries Temporais (SGST). Disponível em: <http://www.bcb.gov.br/?serietemp>. Acesso em 26/08/2013.

BARBOSA, Alexandre de Freitas. O anti-herói desenvolvimentista. Revista Novos Estudos CEBRAP,São Paulo, Edição 94, p. 217-229, nov. 2012.

BIELSCHOWSKY,Ricardo. Evolución de las ideas de la CEPAL. Revista CEPAL, Número Extraordinario, p. 21-45,Octubre 1998.

BRAUDEL, Fernand. A economia em face dos mercados. In: Civilização material, economia e capitalismo - séculos XV-XVIII. São Paulo: Martins Fontes, 1996, cap. 2, p. 192-197. v. 2: Os jogos das trocas.

A produção ou o capitalismo em casa alheia. In: Civilização material, economia e capitalismo - séculos XV-XVIII. São Paulo: Martins Fontes, 1996, cap. 3, p. 199-217. v. 2: Os jogos das trocas.

. As divisões do espaço e do tempo na Europa. In: . Civilização material, economia e capitalismo - séculos XV-XVIII. São Paulo: Martins Fontes, 1996, prefácio e cap. 1, p. 7-58. v. 3: O tempo do mundo.

BRASIL. Portal da Legislação da Casa Civil da Presidência da República. Disponível em: http://www4.planalto.gov.br/legislacao. Acesso em: 15 jul. 2013.

BRENNER, Robert. The origins of capitalist development: a critique of neosmithianmarxism. New Left Review, London, n. I/104, July-August 1977.

BRESSER-PEREIRA, Luiz Carlos. A esperança na industrialização e seus limites. In:

Estado e subdesenvolvimento industrializado. São Paulo:Editora Brasiliense, 1977, cap. XV, p. 201-209.

CABRAL FILHO,Severino Bezerra. Brasil megaestado: pensamento político-estratégico. 1997. 285 fls. Tese (Doutorado em Sociologia) - Faculdade de Filosofia, Letras e Ciências Humanas, Universidade de São Paulo, São Paulo, 1998.

CARNEIRO, Dionísio Dias.Crise e esperança: 1974-1980. In: ABREU, M. P. (org.). A ordem do progresso: cem anos de política econômica republicana, 1889-1989. 13 ${ }^{\mathrm{a}}$ Tiragem. Rio de Janeiro: Campus, 1990, cap. 10, p. 295-322. 
CASTRO, Antônio Barros de. No espelho da China. Revista Custo Brasil, Rio de Janeiro,Ano 3, n. 13, p. 12-22, 2008.

CASTRO, Antônio B. de\& SOUZA, Francisco E. P. de. A economia brasileira em marcha forçada.2 ${ }^{a}$ Edição. Rio de Janeiro: Editora Paz e Terra, 1988.

CERVO, Amado. Relações internacionais do Brasil: um balanço da era Cardoso. Revista Brasileira de Política Internacional, Brasília, v. 45, n. 1, p. 5-35, Jun 2002.

\& BUENO, Clodoaldo. História da política exterior do Brasil. $3^{\mathrm{a}}$ edição revista e ampliada. Brasília: Ed. UnB, 2008.

CHEIBUB, Zairo Borges. Diplomacia e construção institucional: o Itamaraty em uma perspectiva histórica. Dados: Revista de Ciências Sociais. Rio de Janeiro, vol. 28, nº 1, p. 113-131, 1985.

CODATO, Adriano Nervo. Uma história política da transição brasileira: da ditadura militar à democracia.Revista de Sociologia Politica. Curitiba, n 25, p. 83-106, nov. 2005.

DICKEN, Peter. Global shift: transforming the world economy. $3^{\text {a }}$ Edição. New York: The Guilford Press, 1998.

EINCHENGREEN, Barry. A globalização do capital: uma história do sistema financeiro internacional. Tradução Sergio Blum. Apresentação de Alkimar R. Moura. $2^{\mathrm{a}}$ Edição. São Paulo: Editora 34, 2012.

EVANS, Peter. A tríplice aliança: as multinacionais, as estatais e o capital nacional no desenvolvimento dependente brasileiro. Tradução Waltensir Dutra. Rio de Janeiro: Zahar, 1980.

FERNANDES, Ananda Simões. A reformulação da Doutrina de Segurança Nacional pela Escola Superior de Guerra no Brasil: a geopolítica de Golbery do Couto e Silva. Antíteses. Londrina, vol. 2, n 4, p. 831-856, jul-dez 2009.

FIGUEIREDO FILHO, João Sidney de. Políticas monetária, cambial e bancaria no Brasil sob a gestão do Conselho da SUMOC de 1942 a 1955.2005. 201 fls. Dissertação (Mestrado em Economia) - Universidade Federal Fluminense, Niterói, 2005.

FONSECA JUNIOR, Gelson. Mundos diversos, argumentos afins: aspectos doutrinários da Política Externa Independente e do Pragmatismo Responsável. In: A legitimidade $\mathrm{e}$ outras questões internacionais: poder e ética entre as nações. São Paulo: Paz e Terra, 1998, p. 293-352. 
FUNDAÇÃO CENTROS DE ESTUdOS DO COMÉRCIO EXTERIOR. Funcex data.Disponível em: http://www.funcexdata.com.br/cadastramento.asp. Acesso em 28/12/2013.

FURTADO, Celso. Análise do "modelo" brasileiro. 7 a Edição. Rio de Janeiro: Civilização Brasileira, 1972.

. Desenvolvimento e subdesenvolvimento. $3^{\text {a }}$ Edição. Rio de Janeiro: Editora Fundo de Cultura, 1965, capítulo IV, p. 157-185.

. Introdução ao desenvolvimento: enfoque histórico-estrutural. $3^{\text {a }}$ Edição. São Paulo: Paz e Terra, 2000, capítulos II, VII e IX a XI, p. 21-30, 72-83, 95-122.

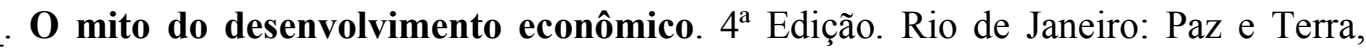
1974, cap. 1 e 2, p. 15-94.

GILPIN, Robert. The challenge of global capitalism: the world economy in the $21^{\text {st }}$ century. New Jersey: Princeton University Press, 2000.

GONÇALVES, Luiz Eduardo Fonseca de Carvalho. As relações Brasil-CEPAL (19471964). Brasília: Fundação Alexandre de Gusmão, 2011.

GONÇALVES, Reinaldo. Economia política internacional: fundamentos teóricos e as relações internacionais do Brasil. Rio de Janeiro: Elsevier, 2005.

GREENSPAN, Alan. The challenge of central banking in a democratic society. The Federal Reserve Board. Remarks at the Institute for Public Policy Research, Washington, D.C., December $\quad$ 5, $1996 . \quad$ Disponível em: http://www.federalreserve.gov/boarddocs/speeches/1996/1991205.htm. Acesso em $13 / 01 / 2014$.

HARVEY, David. A geopolítica do capitalismo. In: A produção capitalista do espaço. São Paulo: Annablume Editora, 2005, cap. 5, p. 127-162.

HIRST, Mônica. Relações internacionais no Brasil como área de pesquisa. In: MICELLI, S. (org.). Temas e problemas da pesquisa em ciências sociais. São Paulo: IDESP, 1992, p. 6474.

O pragmatismo impossível: a política externa do segundo governo Vargas (19511954). Rio de Janeiro: Fundação Getúlio Vargas, Centro de Pesquisa e Documentação de História Contemporânea do Brasil, 1990. 
\& LIMA, Maria Regina Soares de. Brazil as an intermediate state and regional power: action, choice and responsibilities. International Affairs, n. 82, p. 21-40, 2006.

HOBSBAWM, Eric. Era dos extremos: o breve século XX, 1914-1991. Tradução Marcos Santarrita. Revisão técnica Maria Celia Paoli. 2a Edição. São Paulo: Companhia das Letras, 1994.

O novo século: entrevista a Antonio Polito. Tradução Claudio Marcondes e Allan Cameron.São Paulo: Companhia das Letras, 1999.

IEDI. Ocorreu uma desindustrialização no Brasil? Disponível em:

http://www.iedi.org.br/admin_ori/pdf/20051129_desindustrializacao.pdf. Acesso em 22/08/2010.

INSTITUTO BRASILEIRO DE GEOGRAFIA E ESTATISTICA. Estatísticas do Século XX. Rio de Janeiro, 2013. Disponível em: <http://seculoxx.ibge.gov.br/>. Acesso em: 27 dez. 2013.

INSTITUTO DE PESQUISA ECONÔMICA APLICADA (Brasil). Ipeadata: base de dados estatísticos online. Disponível em: <http://www.ipeadata.gov.br/>. Acesso em: 26/08/2013.

INTERNATIONAL MONETARY FUND. World Economic Outlook: October 2013, Transitions and tensions. Washington: IMF, 2013.

KOSELLECK, Reinhart. História dos conceitos e história social. In: Futuro passado: contribuição à semântica dos tempos históricos. Tradução Wilma Patrícia Maas e Carlos Almeida Pereira. Revisão da tradução César Benjamin.Rio de Janeiro: Contraponto Editora PUC-Rio, 2006, capítulo 5, p.98-118.

LAFER, Celso. A identidade internacional do Brasil e a política externa brasileira: passado, presente, futuro. $2^{\mathrm{a}}$ Edição rev. e amp. São Paulo: Perspectiva, 2004.

LAGO, Luiz Aranha Corrêa. A retomada do crescimento e as distorções do "milagre": 19671973.In: ABREU, M. P. (org.). A ordem do progresso: cem anos de política econômica republicana, 1889-1989. $13^{\text {a }}$ Tiragem. Rio de Janeiro: Campus, 1990, cap. 9, p. 233-294.

LIMA, Maria Regina Soares de. A economia política da política externa brasileira: uma proposta de análise. Contexto Internacional. Rio de Janeiro, n. 12, p. 7-28, jul./ dez. 1990. Aspiração internacional e política externa. Revista Brasileira de Comércio Exterior. Brasília, n. 82, ano XIX, p. 4-19, jan./ mar. 2005. 
\& MOURA, Gerson. A trajetória do pragmatismo. Dados - Revista de Ciências Sociais. Rio de Janeiro, v. 25, n. 3, p. 349-63, 1982.

LOVE, Joseph. Economic ideas and ideologies in Latin America since 1930. In: BETHELL, L. (ed.). Ideas and ideologies in twentieth century Latin America. New York: Cambridge University Press, 1996, cap. 3, p. 207-74.

LUDWIG, Armin K. Brazil: a handbook of historical statistics. Boston, MA: G.K. Hall, 1985.

MARTINS, Carlos E. A evolução da PEB na década 64/74. Estudos CEBRAP, São Paulo, no 12, p. 55-98, abril-junho 1975.

MILANI, Carlos R. S. \& PINHEIRO, Letícia. Introdução. In: (org.). Política externa

brasileira: as práticas da política e a política das práticas.Rio de Janeiro: Editora FGV, 2012, p. 13-30.

MINISTÉRIO DO DESENVOLVIMENTO, INDÚSTRIA E COMÉRCIO EXTERIOR (Brasil). Estatísticas de Comércio Exterior - DEPLA. Projeto Aprendendo a Exportar: 200 Anos de Comércio Exterior Brasileiro. Disponível em: $<$ http://www.aprendendoaexportar.gov.br/200anos/html/index.html>. Acesso em 26/08/2013. MOTA, Carlos G.“José Honório Rodrigues: a obra inacabada”. Estudos Avançados. São Paulo,v. 2, n. 3,p. 107-110, sept./dec. 1988.

MOURA, Gerson. Avanços e recuos: a política externa de JK.In: GOMES, Angela de Castro. O Brasil de JK. Rio de Janeiro: Editora FGV/CPDOC, 1991, p. 23-43.

. Autonomia na dependência: a política externa brasileira de 1935 a 1942. Rio de Janeiro: Editora Nova Fronteira, 1980.

. Sucessos e ilusões: relações internacionais do Brasil durante e após a segunda guerra mundial. Rio de Janeiro: Editora FGV, 1991.

NASSIF, André. Há evidências de desindustrialização no Brasil? Revista de Economia Política. São Paulo, v. 28, n. 1, p. 72-96, jan./ mar. 2008.

OLIVEIRA, Nilo Dias de. Os primórdios da doutrina de segurança nacional: a escola superior de guerra. Revista História. São Paulo, v. 29, n. 29, p. 135-157, 2010.

ORENSTEIN, Luiz \& SOCHACZEWSKI, Antonio Claudio. Democracia com desenvolvimento: 1956-61. In: ABREU, M. P. (org.). A ordem do progresso: cem anos de 
política econômica republicana, 1889-1989. 13 ${ }^{\text {a }}$ Tiragem. Rio de Janeiro: Campus, 1990, cap. 6, p. 151-170.

PINHEIRO, Letícia. Política externa brasileira (1889-2002). Rio de Janeiro: Jorge Zahar Editor, 2004 (Coleção Descobrindo o Brasil).

POLANYI, Karl. The great transformation: the political and economic origins of our time. Foreword Joseph E. Stiglitz. Introduction Fred Block. 2nd Edition. Boston, MA: Beacon Paperback Press, 2001.

PRADO JUNIOR, Caio. A Republica burguesa (1889-1930). In: . História econômica do Brasil. Revisão Elide Carvalho Escobar. 26a Edição. São Paulo: Brasiliense, 1976, p. 207-283.

.Formação do Brasil contemporâneo. Revisão Célia Maria Trazzi Cassis. 23 Edição. $7^{\mathrm{a}}$ Reimpressão. São Paulo: Brasiliense, 2004.

. História e desenvolvimento: a contribuição da historiografia para a teoria e prática do desenvolvimento brasileiro. Prefácio Florestan Fernandes. $3^{\text {a }}$ Edição. São Paulo: Brasiliense, 1989, cap. I e VI a IX, p. 17-27 e 48-84.

. O Império escravocrata e a aurora burguesa (1850-1889). In: História econômica do Brasil. Revisão Elide Carvalho Escobar. 26a Edição. São Paulo: Brasiliense, 1976, p. 157-204.

RANGEL, Ignácio. Dualidade básica da economia brasileira (1957). In: BENJAMIN, C. (org.).Obras reunidas. Rio de Janeiro: Contraponto, 2005, v. 1, p. 285-354.

.Economia: Milagre e anti-milagre (1985). In:BENJAMIN, C. (org.).Obras reunidas. Rio de Janeiro: Contraponto, 2005, v. 1, p. 681-742.

.Introdução ao desenvolvimento econômico brasileiro (1955). In:BENJAMIN, C. (org.).Obras reunidas. Rio de Janeiro: Contraponto, 2005, v. 1, p. 129-202.

RESENDE, André Lara. Estabilização e reforma: 1964-1967. In: ABREU, M. P. (org.). A ordem do progresso: cem anos de política econômica republicana, 1889-1989. 13 a Tiragem. Rio de Janeiro: Campus, 1990, cap. 8, p. 213-232.

RICÚPERO, Rubens. Visões do Brasil: ensaios sobre a história e a inserção internacional do Brasil.Rio de Janeiro: Record, 1995.

RODRIGUES, José Honório. Brasil e África: outro horizonte. $3^{\mathrm{a}}$ Edição rev. e at. Rio de Janeiro: Editora Nova Fronteira, 1982. 
. Uma política externa própria e independente. In: - Interesse nacional e

política externa. Rio de Janeiro: Civilização Brasileira, 1966, cap. 2, p. 46-75.

. Interesse nacional e política externa. In: . Interesse nacional e política

externa. Rio de Janeiro: Civilização Brasileira, 1966, cap. 3, p. 76-93.

SINGER, Paul. A crise do milagre. 8a Edição. Rio de Janeiro: Editora Paz e Terra, 1989.

SKINNER, Quentin. Meaning and understanding in the history of ideas. In: Visions of politics. Cambridge: Cambridge University Press, 2002.V. I: Regarding method, cap. 4, p. 57-89.

SOUZA, Amaury. A agenda internacional do Brasil: um estudo sobre a comunidade brasileira de política externa (mimeo). Rio de Janeiro: CEBRI, 2002.

STIGLITZ, Joseph E. A globalização e seus malefícios: a promessa não cumprida de benefícios globais.Tradução Bazán Tecnologia e Linguística. $4^{\mathrm{a}}$ Edição.São Paulo: Futura, 2003.

TAVARES, Maria da Conceição. Acumulação de capital e industrialização no Brasil. Rio de Janeiro: UFRJ, 1971.

(Coord.). O papel do BNDE na industrialização do Brasil: os anos dourados do desenvolvimentismo, 1952-1980. Rio de Janeiro: Centro Internacional Celso Furtado de Políticas para o Desenvolvimento, Ano 4, n 4, 2010. (Série Memórias do Desenvolvimento) UNITED NATIONS CONFERENCE ON TRADE AND DEVELOPMENT. Trade and development report 2003: capital accumulation, growth and structural change. Geneva: UNCTAD, 2003.

VARGAS, Getúlio. Mensagem ao Congresso Nacional. Rio de Janeiro, 1951. Disponível em: $\quad$ http://www.biblioteca.presidencia.gov.br/ex-presidentes/getulio-vargas/mensagenspresidenciais/mensagem-apresentada-na-abertura-da-sessao-legislativa-1951/view. Acesso em 27/01/2014.

VIANNA, Sergio Besserman. Duas tentativas de estabilização: 1951-1954. In: ABREU, M. P. (org.). A ordem do progresso: cem anos de política econômica republicana, 1889-1989. 13ª Tiragem. Rio de Janeiro: Campus, 1990, cap. 5, p. 123-150.

Política econômica externa e industrialização: 1946-1951. In: ABREU, M. P. (org.). A ordem do progresso: cem anos de política econômica republicana, 1889-1989. 13 ${ }^{\text {a }}$ Tiragem. Rio de Janeiro: Campus, 1990, cap. 4, p. 105-122. 
VISENTINI, Paulo Fagundes. A política externa do regime militar brasileiro: multilateralização, desenvolvimento e construção de uma potência média, 1964-1985.Porto Alegre: Editora da Universidade, UFRGS, 1998.

. Relações internacionais do Brasil: de Vargas a Lula. $3^{a}$ Edição rev. e amp.São Paulo: Editora Fundação Perseu Abramo, 2008.

WALLERSTEIN, Immanuel. The rise and demise of the world capitalist system: concepts for comparative analysis. In: . The essential Wallerstein. New York: The New Press, 2000, cap. 5, p. 71-105. 